\title{
Visões de Otelo na cena e na literatura dramática nacional do século XIX
}

\section{Daniela Ferreira Elyseu Rhinow}

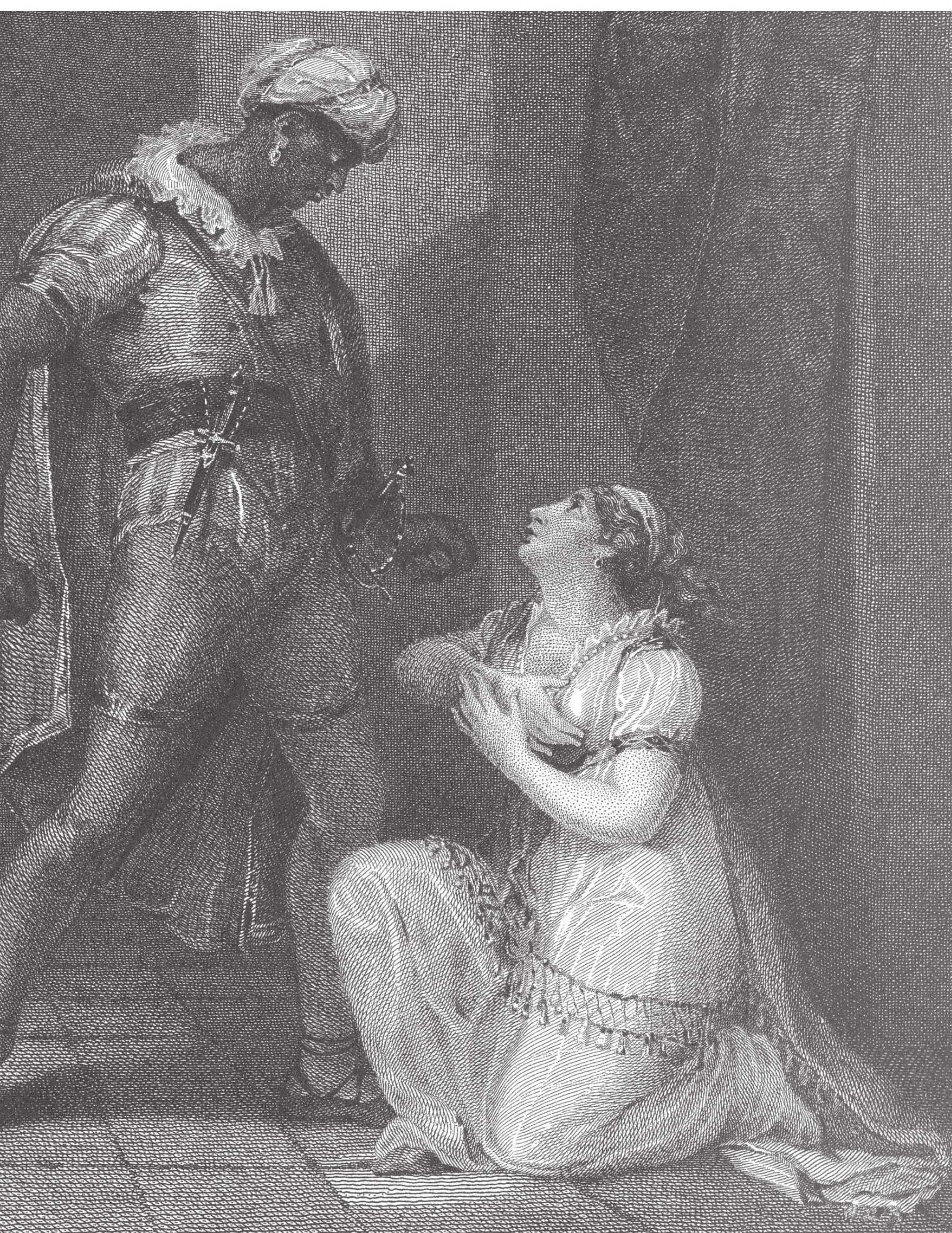




\author{
UNIVERSIDADE DE SÃO PAULO \\ FACULDADE DE FILOSOFIA, LETRAS E CIÊNCIAS HUMANAS \\ DEPARTAMENTO DE LETRAS CLÁSSICAS E VERNÁCULAS \\ PROGRAMA DE PÓS-GRADUAÇÃO EM LITERATURA \\ BRASILEIRA
}

\title{
Visões de Otelo na cena e na literatura dramática nacional do século XIX
}

DANIELA FERREIRA ELYSEU RHINOW

Tese apresentada ao Programa de Pós-Graduação em Literatura Brasileira, do Departamento de Letras Clássicas e Vernáculas da

Faculdade de Filosofia, Letras e Ciências Humanas, da Universidade de São Paulo, para a obtenção do título de Doutor em Letras.

Orientador: Prof. Dr. João Roberto Gomes de Faria

\author{
SÃO PAULO \\ 2007 \\ Volume 1
}




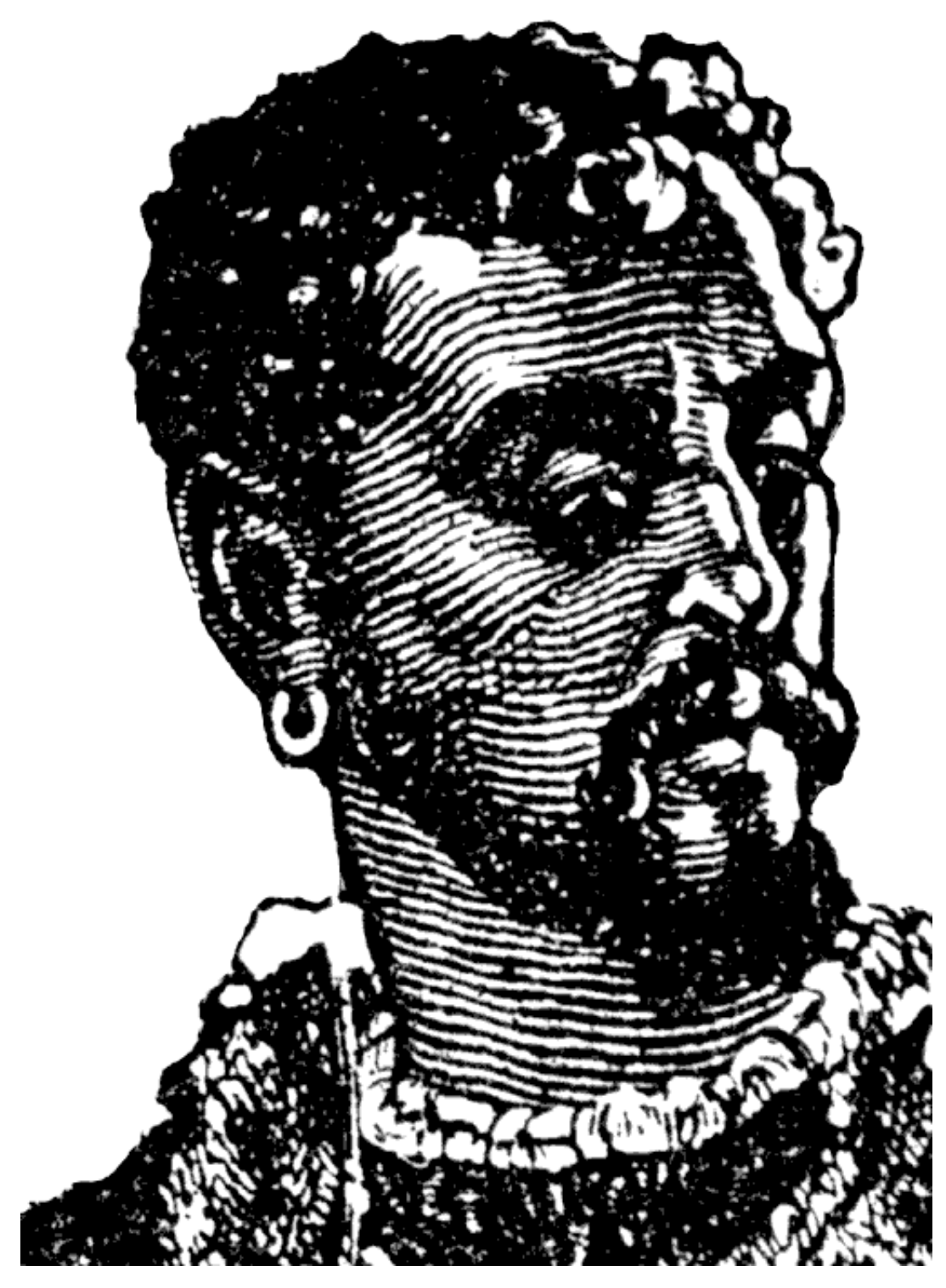

Fonte: www.etc.usf.edu, último acesso em 07/06/2007.

Source: Charles and Mary Lamb, Tales from Shakespeare

(Philadelphia: Henry Altemus Company, 1901). 
Para Guilherme, André, Gabriel e quem mais chegar... 
Comme jaloux, je souffre quatre fois : parce que je suis jaloux, parce que je me reproche de l'être, parce que je crains que ma jalousie ne blesse l'autre, parce que je me laisse assujettir à une banalité : je souffre d'être exclu, d'être agressif, d'être fou et d'être commun.

R. Barthes, Fragments d'un Discours Amoureux 


\section{Agradecimentos}

Ao meu marido, Guilherme, que me apoiou incondicionalmente durante todas as fases de meu doutorado; aos meus filhos, André e Gabriel, que tiveram que lidar com as minhas ausências em certos momentos e são constante fonte de inspiração.

À minha família, que me ajudou de muitas formas; meu pai, Elyseu, e minha mãe, Cláudia, que sempre reconheceram meu esforço e que deram meios para meu aprendizado constante; Leda e Kurt, meus sogros, não só pela torcida, mas por perder um dia todo de férias na Biblioteca Nacional, em busca de um manuscrito para este trabalho; minha tia Renata Ferreira que, morando no Rio de Janeiro, também conseguiu dois textos na Biblioteca Nacional para mim.

Ao Prof. Dr. João Roberto Faria, meu orientador - no amplo sentido da palavra -, que me acolheu e permaneceu presente durante toda a elaboração da tese, sempre em busca da melhoria, da contribuição e da qualidade.

A CAPES, que, concedendo-me uma bolsa de estudos, possibilitou que eu pudesse me dedicar, por um bom período, exclusivamente ao trabalho acadêmico e a esta tese.

Aos membros de minha banca de qualificação, Prof. Dr. John Milton e Prof. Dr. Flávio Aguiar, pelas inúmeras contribuições e a constatação de que o capítulo sobre as companhias estrangeiras era essencial e merecia um profundo investimento, e de que o levantamento exaustivo de críticas nos jornais da época era crucial. O professor John Milton tem acompanhado há tempos meus estudos, sempre demonstrando grande generosidade, emprestando livros e dando sugestões pelo caminho. Minha gratidão para com John é imensa. O professor Flávio colaborou com reflexões importantes e estímulo, e também foi muito disponível em relação ao projeto. 
Ao Prof. Dr. Luís Fernando Ramos, da ECA / USP, por ter me convencido, numa noite em um Bierstube de Salzburgo, no ano 2000, de que eu deveria estudar Shakespeare no doutorado, e descobrir como fora a entrada de Shakespeare no Brasil. Esta tese é, em última instância, o resultado daquela conversa. Espero que algumas das respostas às perguntas de então estejam aqui!

Ao Prof. Dr. José Miguel Wisnik, pela intimação, em seu (ótimo) curso de pósgraduação, para que eu the escrevesse, no paper final, sobre as relações entre Otelo e Dom Casmurro. Além de ampliar enormemente meu conhecimento sobre Machado de Assis, esse trabalho abriu novas portas de reflexão na tese, e levantou questões interessantes. De nada adiantou dizer a Wisnik que eu pretendia focar apenas na dramaturgia brasileira. Sua resposta foi: "Você vai passar do lado de uma montanha e fingir que não a viu?" Obrigada por me ajudar na escalada.

À Profa. Dra. Maria Cecília Queiroz de Moraes Pinto, da área de Francês da FFLCH / USP, que gentilmente aceitou minha presença em suas aulas de graduação sobre a história do teatro francês, e que se dispôs a responder minhas perguntas a propósito de teóricos e dramaturgos franceses dos séculos XVIII e XIX.

A Gabriela de Mello Freire e Anne-Béatrice Schmidt, pelo auxílio na revisão de traduções, respectivamente, do francês e do italiano, presentes na tese.

Aos funcionários das seguintes instituições: Biblioteca da FFLCH / USP; Biblioteca da ECA / USP; Biblioteca do Departamento de Inglês da Unibasel, na Basiléia; Biblioteca Roger Batit, Paris III, Sorbonne; Bibliothèque Nacionale, Paris (Arsenal); e Biblioteca do Salzburg Seminar, Schloss Leopoldskrom, Salzburgo. Além do trabalho com eficiência na disponibilização de textos centrais para o projeto, deparei-me com acolhimento e interesse pela pesquisa. 
Aos funcionários do Arquivo Edgard Leuenroth, da UNICAMP, pela cordialidade e auxílio no processo de buscas de artigos nos microfilmes de jornais do século XIX, e na reprodução eletrônica dos mesmos. A compra e disponibilização dos arquivos da Biblioteca Nacional pela UNICAMP e a disponibilidade total de seus funcionários foi uma ajuda inestimável para este trabalho.

Aos amigos Rogério Ópice e Kleber Oliveira, que me ajudaram na digitalização e na formatação do anexo de imagens. A Fernanda Ballura de Helfst, amiga querida e sempre presente nos momentos necessários. A Ângela Mandari, pela ajuda incondicional em vários níveis, inclusive no braçal. Poder contar com vocês é um privilégio e uma alegria.

Last but not least, ao meu querido e inesquecível orientador de mestrado, Eudinyr Fraga, que nos deixou em 2001. Você acreditou em mim desde a graduação, e sei que pretendia me orientar no doutorado. Este trabalho - e certamente João há de concordar comigo - também é para você. 
ÍNDICE

RESUMO 1

ABSTRACT

RESUMÉ .3

SOBRE NOTAS BIBLIOGRÁFICAS E TRADUÇÕES .4

INTRODUÇÃO - DA PRESENÇA SHAKESPEARIANA NO BRASIL NO SÉCULO XIX AO CASO OTELO

PARTE 1 - TRAJETÓRIAS DE OTELO DA EUROPA AO BRASIL 13

1.1 - 0 OTELO SHAKESPEARIANO E SEUS (DES)CAMINHOS NA FRANÇA

1.2 - PORTAS DE ENTRADA NA CENA NACIONAL

1.2.1 - O TEXTO DE DUCIS E A TRADUÇÃO DE GONÇALVES DE MAGALHÃES.

1.2.2 - A ENCENAÇÃO DE JOÃO CAETANO PARA O TEXTO DE DUCIS ....28

1.2.3 - OS OUTROS OTELOS DE JOÃO CAETANO 36

1.2.4. - OS OTELOS NO REPERTÓRIO DE JOÃO CAETANO ……………........76

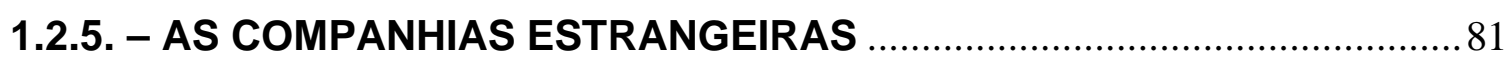

1.2.6 - A ÓPERA ITALIANA E A CENA LÍRICA NACIONAL ............................125

PARTE 2 - OTELOS BRASILEIROS NO SÉCULO XIX 153

2.1 - OTELO COMO PROCEDIMENTO ESTRUTURANTE. 153

2.1.1 - MARTINS PENA: OS CIÚMES DE UM PEDESTRE 153

2.1.2 - A DESDÊMONA AMBÍGUA: LEONOR DE MENDONÇA, DE GONÇALVES DIAS 
2.1.3 - O OTELO ESVAZIADO: O NOVO OTHELO, DE JOAQUIM MANUEL DE MACEDO 176

2.1.4 - ALUÍSIO AZEVEDO E EMÍLIO ROUĖDE: O CABOCLO 187

2.1.5- OUTROS AUTORES

CONCLUSÃO

ANEXOS.

ANEXO 1 - QUADRO COMPARATIVO ENTRE O NOVO OTHELO, DE J. M. MACEDO, E O OTHELO DE DUCIS

ANEXO 2 - IMAGENS

ANEXO 3 - ARTIGOS DE JORNAL E DOCUMENTOS RELATIVOS AOS ARTISTAS QUE INTERPRETARAM OTELO NO BRASIL 


\section{RESUMO}

A tese "Visões de Otelo na cena e na literatura dramática nacional do século $X I X "$ trata da chegada da personagem Otelo nos palcos do Rio de Janeiro no século XIX e de suas apropriações em obras de autores brasileiros do período. Propondo-se a elencar os textos encenados nos teatros cariocas, o trabalho trata de representações do original shakespeariano, em inglês ou em traduções italianas; de versões francesas de cunho classicista; de óperas italianas sobre o tema; e de traduções portuguesas trazidas por companhias estrangeiras. A recepção de tais encenações pela crítica nacional é contemplada, buscando uma visão mais ampla da repercussão das mesmas. Em um segundo momento, analisa-se como tais obras foram apropriadas em uma produção dramatúrgica nacional, sendo os principais exemplos peças de autores como Martins Pena, Joaquim Manuel de Macedo, Gonçalves Dias e Aluísio Azevedo. A partir do estudo das peças e de documentos do período, pretende-se que uma visão mais clara da trajetória da personagem no Brasil seja estabelecida, bem como a extensão de sua influência em dramaturgos importantes na formação do teatro brasileiro.

PALAVRAS-CHAVE: dramaturgia, encenação, apropriação, teatro brasileiro, Shakespeare. 


\section{ABSTRACT}

The thesis "Visions of Otelo in the scene and the Brazilian dramatic literature of the nineteenth century" deals with the arrival of the character Otelo on the stages of the city of Rio de Janeiro in the nineteenth century, and its appropriations in works by Brazilian authors of the period. Seeking to study the texts staged in Rio, the work tackles representations of the original Shakespearian text, in English or Italian translations; French versions of classicist spirit; Italian operas on the subject; and Portuguese translations brought by foreign companies. The reception of such stagings by the national press is contemplated, searching an ampler vision of their repercussion. Secondly, there is the analysis on how such texts have been appropriated into a national dramatic production, the main examples being plays by authors such as Martins Pena, Joaquim Manuel de Macedo, Gonçalves Dias and Aluísio Azevedo. From the study of the plays and documents from the period, it is the intention of this work to establish a clearer vision of the trajectory of the character in Brazil, as well as the extension of its influence in important writers in the formation of the Brazilian drama.

KEY WORDS: drama, performance, appropriation, Brazilian theatre, Shakespeare. 


\section{RESUMÉ}

La thèse "Visions d'Otelo dans la scène et dans la littérature dramatique nationale du XIXème siècle" traite de l'arrivée du personnage Otelo sur la scène au Rio de Janeiro dans le XIXème siècle et de ses appropriations dans des œuvres d'auteurs brésiliens de la période. En se proposant à étudier les textes mis en scène dans les théâtres à Rio, le travail traite de représentations de l'original shakespearien, en anglais ou en traductions italiennes; de versions françaises d'empreinte classiciste; d'opéras italiens sur le sujet; et de traductions portugaises apportées par des sociétés étrangères. La réception de telles mises en scène par la critique nationale est envisagée, en cherchant une vision plus vaste sur leur répercussion. Secondement, on analyse comment telles œuvres ont été appropriées dans une production dramaturgique nationale, les principaux exemples étant pièces d'écrivains comme Martins Pena, Joaquim Manuel de Macedo, Gonçalves Dias et Aluísio Azevedo. À partir de l'étude des pièces e des documents de la période, c'est notre intention qu'une vision plus claire de la trajectoire du personnage au Brésil soit établie, ainsi que l'extension de son influence dans des dramaturges importants dans la formation du théâtre brésilien.

MOTS CLÉFS : dramaturgie, représentation, appropriation, théâtre brésilien, Shakespeare. 


\section{SOBRE NOTAS BIBLIOGRÁFICAS E TRADUÇÕES}

Devido ao grande número de obras e documentos citados no trabalho, muitos originais do século XIX, alguns cuidados foram tomados em relação às citações dos mesmos ao longo do texto. As principais opções foram:

1 - Adaptou-se a grafia dos textos citados às normas ortográficas vigentes, referindo-se à grafia original quando houve interesse em realçar fatos prosódicos.

II - Os títulos de periódicos e de seções dos jornais consultados também foram adaptados ao padrão atual de grafia. Assim, por exemplo, a seção Theatros e Música, do Jornal do Commercio, é referida como Teatros e Música, do Jornal do Comércio.

III - Os nomes das personagens das obras foram, no geral, mantidos no original. Assim, dependendo da obra, a personagem Otelo é referida como Othello, Othelo, ou Otelo; e lago como Yago, lago, ou Jago (no caso da ópera de Verdi e Boito). As diferentes grafias utilizadas pelos críticos em artigos também foram mantidas como indicadas no texto original. Foram adaptados ao português apenas os nomes próprios, no caso de ter havido tradução utilizada no período estudado. Assim, Hedelmonde, do Othelo de Ducis, é referida como Hedelmonda, seguindo a tradução de Gonçalves de Magalhães utilizada por João Caetano. Desdêmona, grafada no período Desdemona, recebeu o acento adequado. $\mathrm{O}$ nome Shakespeare foi mantido nas diferentes grafias presentes nos periódicos, inclusive para demonstrar as alternâncias recorrentes entre as diversas formas.

IV - As citações de textos ainda não traduzidos para o português, sejam peças ou comentários críticos, foram traduzidas por mim, visando manter o sentido geral ainda que, ocasionalmente, em detrimento da qualidade literária. As notas de rodapé indicam a referência ao texto original consultado. 
V - As epígrafes dos capítulos, em sua maioria, não foram traduzidas, visando manter o sentido original ao máximo.

$\mathrm{VI}$ - Foram adotadas as normas já convencionadas para as peças de Shakespeare. Assim, por exemplo, a cena III do $3^{\circ}$ ato de Otelo é referida como Otelo III, iii. 


\title{
INTRODUÇÃO - DA PRESENÇA SHAKESPEARIANA NO BRASIL NO SÉCULO XIX AO CASO OTELO
}

\author{
"Nesta capital, onde, infelizmente, vive em abandono e no desprestígio \\ a arte dramática, têm sido admirados notabilíssimos intérpretes \\ do personagem do Othello. Vimos e ouvimos Rossi, Salvini, Emanuel, \\ Novelli e o nosso imortal João Caetano. Todos eles, artistas de gênio, foram \\ extraordinários no desempenho do papel do Mouro de Veneza; \\ cada um desses heróis do palco desempenhou, segundo o seu temperamento, \\ o papel do fogoso, terno e criminoso Othello, cada um o interpretou, \\ sem faltar entretanto à verdade, segundo o seu gênio, imprimindo-lhe \\ um cunho acentuadamente individual, de modo a enfraquecer e aniquilar \\ a teoria errônea do confronto, tão empregada pela crítica."
} Jornal do Comércio, 06/05/1891, p. 1

Harold Bloom, um dos mais polêmicos críticos contemporâneos da obra de Shakespeare, considera o bardo inglês como o centro do cânone ocidental, e como o próprio criador da noção do ser humano moderno, com toda a sua articulação de conhecimento de mundo e de si mesmo. Isso porque, tomando a expressão cunhada por Hegel, as personagens shakespearianas seriam as primeiras, na história da literatura, a serem "artistas livres de si mesmas", podendo entreouvir seus próprios pensamentos e ações no decorrer do enredo*. Quer concordemos ou não com Bloom, o fato é que a abrangência e a popularidade da obra shakespeariana são inegáveis. Traduz-se Shakespeare para línguas tão díspares quanto o português e o swahili, o alemão e o bengali, o japonês e o grego. Shakespeare é encenado por todo o mundo, às vezes mantendo-se uma reverência clássica à obra, às vezes usando-a como ponto de partida para experimentações dos mais variados graus.

Em vários países, existem pesquisas extensas sobre a apropriação cultural da obra shakespeariana, e sobre o histórico de traduções, adaptações e encenações das peças no país em questão. Bons exemplos incluem a Alemanha, onde a admiração por Shakespeare, desde o século XVIII, motivou

\footnotetext{
" a propósito, vide BLOOM, Harold. Shakespeare and the Invention of the Human. New York, Riverhead, 1998, entre outras obras.
} 
até o aparecimento da expressão Unser Shakespeare - "Nosso Shakespeare". Hauptmann, em 1915, chegou a afirmar que Shakespeare estava mais vivo na Alemanha do que em qualquer outra nação, inclusive a Inglaterra. Outro exemplo interessante é a Índia, que primeiramente recebeu Shakespeare como uma imposição do colonialismo britânico para depois dele se apossar, adaptando-o para formas teatrais tradicionais.

Como uma obra de tal magnitude penetrou no Brasil? Que leituras e apropriações foram empreendidas? Esta tese foi iniciada tendo por objetivo investigar a entrada de Shakespeare ao Brasil no século XIX, analisando suas versões francesas setecentistas, de Voltaire e de Ducis, por exemplo, na cena do Rio de Janeiro e, em seguida, os autores da dramaturgia nacional que escreveram peças que dialogam com a obra do autor inglês. O estudo focaria, particularmente, no caso de Otelo e de suas versões na literatura dramática brasileira no período em questão, demonstrando a intensa recorrência do protagonista dessa peça em relação a outras personagens do cânone shakespeariano.

O projeto inicial pretendia não apenas passar a limpo certas questões debatidas ao longo do tempo por estudiosos do teatro brasileiro - por exemplo, se João Caetano encenou ou não o Otelo de Shakespeare, alternando-o com a adaptação de Ducis, traduzida para o português por Gonçalves de Magalhães - mas também, e principalmente, demonstrar como a apropriação da personagem foi perene em nossas terras, ensejando um número considerável de obras que se valem de Otelo em maior ou menor grau. Algumas peças verdadeiramente se impregnam do enredo e das personagens da obra anterior (como $O$ novo Othelo, de Macedo, que parodia o texto duciano), enquanto outras fazem mera citação (como O Protocolo, de Machado de Assis). De qualquer modo, é interessante perceber o fenômeno da citação, que indica um presumido conhecimento prévio do público.

Um dos objetivos do projeto, assim, seria o de contribuir para os estudos sobre as relações entre Shakespeare e o Brasil e sobre a própria literatura dramática nacional. Há três obras publicadas que se ocuparam, ainda que 
marginalmente, do assunto, mas que não esgotaram a questão, até porque não era tal a proposta de nenhuma delas.

O primeiro trabalho é o de Celuta Moreira Gomes, William Shakespeare no Brasil, de $1961^{1}$. A obra, na verdade, é um livro de referência bibliográfica de valor inestimável, muito abrangente, que trata das citações de obras do dramaturgo inglês em textos publicados no Brasil até 1954 (livros, periódicos, tudo o que pudesse ser encontrado nos arquivos da Biblioteca Nacional). A autora inclui desde traduções, adaptações e paródias das peças até críticas e artigos sobre representações de artistas nacionais e de companhias estrangeiras quando em solo brasileiro. Sem dúvida, é uma obra de fôlego, mas que não se propõe a analisar os textos arrolados ou a desenvolver uma reflexão sobre a recorrência de Shakespeare no país.

segundo livro, também datado de 1961, é Shakespeare no Brasil, de Eugênio Gomes ${ }^{2}$, que traz elementos interessantes sobre a cronologia das encenações das peças de Shakespeare e das versões francesas e sobre a influência do dramaturgo em diversos autores. Há, porém, algumas diferenças em relação a este trabalho. Em primeiro lugar, o autor não se restringe aos dramaturgos: há capítulos relevantes sobre Gonçalves Dias e Álvares de Azevedo, mas trata-se também de escritores como Cruz e Sousa, Olavo Bilac e Rui Barbosa. O capítulo sobre Machado de Assis não analisa sua obra dramática, o que faz falta. Além disso, há um foco considerável nas traduções e em questões diferentes daquela apontada no título do livro. Há uma série de capítulos que discutem temas da obra shakespeariana no geral, e não em sua relação com o Brasil. Exemplos incluem "A rima em Shakespeare", "Hamlet através dos tempos", "O Hamlet de Olivier", e "Impressões de Stratford-UponAvon", que narra a visita do autor à terra natal do bardo. Todo o material não relativo ao Brasil acaba por ocupar quase quarenta por cento da obra.

\footnotetext{
${ }^{1}$ GOMES, Celuta Moreira. William Shakespeare no Brasil. Rio de Janeiro, MEC, 1961.

${ }^{2}$ GOMES, Eugênio. Shakespeare no Brasil. Rio de Janeiro, MEC/ Serviço de Documentação, 1961.
} 
Finalmente, temos um artigo curto de Bárbara Heliodora, "Shakespeare in Brazil", publicado na Shakespeare Survey no. 20, de $1967^{3}$. Nele, temos um esboço da recepção de Shakespeare no país, em termos de traduções, encenações e adaptações. Aparece ainda aqui a crença - também presente no livro de E. Gomes - de que João Caetano teria encenado os textos shakespearianos originais e não apenas as versões de Ducis, o que Décio de Almeida Prado refutaria posteriormente em seu estudo sobre o ator. Das peças nacionais inspiradas em Otelo, apenas Os Ciúmes de um Pedestre, de Martins Pena, é citada. A presença das companhias italianas e francesas desde 0 século XIX é descrita por alto, e o texto demora-se mais em montagens brasileiras das peças originais a partir de 1938, com a famosa encenação de Romeu e Julieta pelo Teatro do Estudante do Brasil (TEB).

Faz-se mister, portanto, um estudo exaustivo traçando as apropriações de Shakespeare pela literatura nacional, especialmente em termos de dramaturgia. $O$ romance brasileiro até já foi contemplado em obras como $O$ Otelo brasileiro de Machado de Assis, de Helen Caldwell, traduzido para o português em 2000, que analisa Dom Casmurro. Porém, a cena nacional ainda não foi retratada minuciosamente. A própria publicação, em 2002, da peça (até então inédita) $O$ Caboclo, de Aluísio Azevedo e Emílio Rouède, calcada em Otelo, demonstrara a existência de material novo para estudo. Além disso, a documentação da cena brasileira no período poderia ser enriquecida, com o aprofundamento da análise sobre a interpretação de João Caetano - que fez seu nome partindo de textos neoclássicos, apesar da atuação claramente romântica - e de seus escritos, que citam o papel de Otelo, e também com a discussão sobre a importância da passagem das companhias estrangeiras em terras nacionais. Salvini e Rossi, por exemplo, foram dois dos Otelos mais importantes do século XIX, tendo sido aclamados inclusive na Inglaterra e nos Estados Unidos, mesmo atuando em italiano, e encantaram as platéias cariocas, em tournées importantes, mas pouco estudadas. Finalmente, a figura abrangente e marcante de Shakespeare na literatura mundial ratificaria a importância do assunto, dando margem a um estudo da literatura brasileira.

\footnotetext{
3 ALMEIDA, Bárbara Heliodora. "Shakespeare in Brazil", in Shakespeare Survey no. 20. Cambridge, Cambridge University Press, 1967, pp. 121-124.
} 
A partir de tais pressupostos, surgiram inúmeras questões a serem respondidas, muitas delas se ligando à já mencionada preponderância de Otelo nos palcos nacionais do período citado, dentre todas as obras shakespearianas. Nada leva a crer que tal preferência se deva à presença do protagonista negro, uma discussão que poderia ser relevante em um país que se livrará da escravidão no decorrer do século XIX. Mas qual o papel do negro no teatro brasileiro do período? A questão já foi examinada, por exemplo, por Miriam Garcia Mendes ${ }^{*}$, mas não explica o fenômeno Otelo. A recorrência do texto parece se dever mais à estrondosa popularidade da personagem criada por João Caetano a partir do texto de Ducis, pelo entrecho sentimental latente e pelo seu potencial também cômico do que por qualquer razão de caráter social mais amplo. Considerada a mais "doméstica" das quatro grandes tragédias de Shakespeare, Otelo se presta, no Brasil, tanto a uma exploração cômica de seu enredo (de resto, absolutamente plausível, como demonstra Bárbara Heliodora ${ }^{4}$ ) quanto a um tratamento mais sério, por vezes romântico.

Nesse momento, uma série de questões diretrizes e de hipóteses surgiu. Entre elas, podemos destacar as seguintes: o Otelo de Ducis dominaria a cena nacional e inspiraria autores em um patamar acima de Shakespeare; a encenação de João Caetano é central para a recepção da personagem no Brasil; outras versões, inclusive a de Shakespeare, também circulam e às vezes se misturam; é só com o passar do tempo que o texto shakespeariano se impõe como fonte; a importância da personagem é grande o suficiente para receber atenção concentrada em certas obras de autores nacionais que tiveram contato com textos e/ou encenações de Otelo, e ainda para ser citada de passagem em outras obras, o que pressupõe conhecimento compartilhado entre autores e leitores/público.

Claro fica, assim, que a questão central não deveria ser Shakespeare em si. Devemos, ao invés disso, nos perguntar qual é o lugar de Otelo na formação

\footnotetext{
* Vide MENDES, Miriam Garcia. A Personagem Negra no Teatro Brasileiro (entre 1838 e 1888). Dissertação de Mestrado. São Paulo, ECA / USP, s/d.

4 Vide HELIODORA, Bárbara."Otelo, uma Tragédia Construída sobre uma Estrutura Cômica", in Falando de Shakespeare. São Paulo, Perspectiva, 1997.
} 
do repertório brasileiro, qual é a medida em que ele atua nas balizas nascentes de nosso teatro. E aqui, a pergunta se refere realmente a Otelo, e não a Shakespeare, pois o que se via e o que se lia no país, em especial no Rio de Janeiro, foco básico do estudo, não necessariamente se referem ao autor inglês. O objetivo essencial desta tese, portanto, é responder à seguinte questão: quais os Otelos que aportaram no Rio de Janeiro do século XIX, e quais suas contribuições para a criação do repertório dramatúrgico nacional?

Com isso, o estudo analítico aborda a trajetória das adaptações de Otelo, em especial na França, base para os textos aqui aportados; depois, o foco recai sobre a questão central, dividida em dois pontos: as portas de entrada da personagem no Brasil e os usos dela feitos pelos artistas e dramaturgos nacionais. No primeiro caso, temos o trabalho de João Caetano sobre Otelo, a partir da tradução de Gonçalves de Magalhães para o texto de Ducis; sobre Orosmane, de Zaïre, de Voltaire; e sobre a personagem-título de Kean, de Dumas (além da composição de outras personagens, como o Hamlet também calcado em Ducis); temos também as encenações do texto de Shakespeare por companhias teatrais estrangeiras, desde a companhia espanhola de Adolfo Ribelli, em 1838, até as companhias italianas de Ernesto Rossi e de Tommaso Salvini, provavelmente o maior Otelo do período, entre 1871 e 1896, além das encenações das óperas de Verdi e de Rossini, a partir de 1847. No segundo caso, temos as apropriações cômicas do enredo e das personagens do Otelo de Ducis, primeiramente por Martins Pena (Os Ciúmes de um Pedestre, Judas em Sábado de Aleluia), e depois por Joaquim M. de Macedo (O Novo Othelo); por fim, merecem reflexões os escritos dos primeiros leitores de Shakespeare no original inglês, como Gonçalves Dias (Leonor de Mendonça), bem como uma peça de Aluísio Azevedo (O Caboclo), e as citações de Machado de Assis.

Finalmente, dada a abundância de documentação factual sobre os Otelos do período - artigos de jornal, críticas, anúncios, fotos - julgou-se interessante fazer uma compilação abrangente de tais dados nos anexos finais, de forma a enriquecer e expandir a compreensão do significado desses Otelos na época. A relevância de todo esse material salta aos olhos durante a leitura e fala por si só, incitando novos questionamentos e projetos. Espera-se, assim, com o 
estudo aqui apresentado e a compilação de material, em grande parte artigos não recuperados ou reeditados dos jornais da época, contribuir para a construção do conhecimento sobre o teatro no Brasil no século XIX, e para compor um panorama mais amplo da presença de Shakespeare no Brasil por meio do estudo da dramaturgia nacional. 


\section{1 - O OTELO SHAKESPEARIANO E SEUS (DES)CAMINHOS NA FRANÇA}

«Voilà la dernière scène de cette abominable boucherie, plutôt que tragédie ;

il y a horreur, mais peu de talent...

L'horreur seule a attaché le peuple à cette abomination. »

Lamartine

Hoje em dia, a associação da peça Otelo com o nome do dramaturgo William Shakespeare parece ser óbvia. Porém, nem sempre as coisas se deram dessa forma: na verdade, em certos períodos e lugares, outros autores foram associados à tragédia do mouro de Veneza. É o caso, por exemplo, do Rio de Janeiro no início do Romantismo, uma época na qual a peça em questão evoca o nome do dramaturgo neoclássico francês Jean-François Ducis, cuja heroína recebe o nome de Hedelmonde, entre outras peculiaridades. Sua obra servirá não apenas para o início da glória do ator João Caetano, mas também para inspirar outras peças entre dramaturgos nacionais - em especial no gênero da comédia (o que, em certo sentido, parece justificável, dado o tipo de intriga e personagens envolvidos ${ }^{5}$ ). Mas para compreender por que isso se deu, é necessário retroceder e compreender 0 percurso feito pelo texto shakespeariano até o Brasil, em especial a sua passagem pela França.

O papel de Otelo é o que mais repetidamente tem sido associado ao nome de João Caetano, o primeiro grande ator nacional. Porém, quando vamos um pouco mais a fundo na investigação de tal papel, concluímos que as relações do ator com a personagem não se resumem a um texto só. Podemos reconhecer Otelo, na verdade, em pelo menos três textos - franceses encenados por João Caetano: o Otelo de Ducis, que o consagrou; Zaíra de Voltaire, também uma tragédia neoclássica; e Kean, ou Desordem e Gênio, de

\footnotetext{
5 Vide HELIODORA, Bárbara. "Otelo, uma Tragédia Construída sobre uma Estrutura Cômica”, in Falando de Shakespeare. São Paulo, Perspectiva; Rio de Janeiro, FUNARTE / Cultura Inglesa, 1997, pp. 275-286.
} 
Alexandre Dumas. Devemos, pois, voltar nossos olhos para a França e compreender porque tais peças bebem em Otelo e porque o texto shakespeariano foi tão modificado no país no período em questão.

Mas voltemos, ainda uma vez, a João Caetano, tantas vezes elogiado como o primeiro ator shakespeariano no Brasil por críticos como Pires de Almeida. Ao ler as Lições Dramáticas, deparamo-nos com o seguinte trecho: "Seja a primeira fala do mouro de Veneza, na tragédia Otelo: "Eu me calo, Odalberto". ${ }^{6}$ A surpresa se deve ao fato de que nós, no século XXI, imediatamente associamos a peça Otelo com o autor Shakespeare, e Odalberto não é o nome de nenhuma de suas personagens - no caso, o pai de Desdêmona chama-se Brabâncio. Mas no século XIX tal associação não era imediata. Prova disso é a necessidade que Gonçalves Dias sentiu, no prólogo de Leonor de Mendonça, de fazer a seguinte indicação: "[o duque] é cioso não porque ama, mas porque é nobre". É esta a diferença que há entre Otelo e D. Jaime." Em nota de rodapé, ele explica: "Falo do Otelo de Shakespeare." ${ }^{7}$ Se Gonçalves Dias faz tal ressalva, está claro que, no período, Otelo era uma personagem que evocava o nome de outro autor. No caso, o de Jean-François Ducis.

Mas como chegamos a este Otelo francês, hoje abandonado e quase totalmente desconhecido? Enquanto Shakespeare, na Inglaterra, foi o ponto mais alto do teatro elisabetano (ou isabelino), na França o modelo que estava se solidificando era o do Neoclassicismo, determinado por leis bastante rígidas que se baseavam na releitura prescritiva das Poéticas de Aristóteles e de Horácio a partir do Renascimento - e cujo principal exemplo seria a Art Poétique, de Boileau, publicada em 1674. Tendo por princípios a instrução moral, a regra e não a inspiração como central para o fazer artístico, o culto da razão e a imitação (da natureza e dos antigos), o modelo se pautava em primeiro lugar pela lei da verossimilhança (interna e externa) da obra; dela derivam as regras das três unidades - ação, tempo e espaço -, além da regra das conveniências, a unidade de tom e a busca de um perfeito encadeamento

\footnotetext{
${ }^{6}$ SANTOS, João Caetano dos. Lições Dramáticas. Rio de Janeiro, Serviço de Documentação - MEC, 1955 , p. 17.

${ }^{7}$ GONÇALVES DIAS, A. Teatro Completo. Rio de Janeiro, Serviço Nacional do Teatro, 1979, P. 61.
} 
lógico, sem elementos supérfluos. As peças se caracterizam por ações relativamente simples, que se desenvolvem pelas emoções das personagens.

Evidentemente, Shakespeare não se enquadrava nesse modelo. No momento da composição de Othello (1602, com revisão em 1606), Shakespeare já era um autor consagrado, em uma atividade popular e organizada, nos moldes ingleses. $O$ formato do teatro elisabetano e as obras para ele concebidas vinham se fixando há mais de uma geração, e Shakespeare já havia não só suplantado seus antecessores diretos - Kyd, Nashe, Poole, e mais notadamente Christopher Marlowe - como media forças, com vantagem, com a nova geração - cujo maior expoente seria Ben Jonson, e que compreenderia ainda Fletcher (que colaborou com Shakespeare no final da carreira deste) e Beaumont.

As fontes da tragédia sobre o mouro de Veneza, general que se casa com uma dama italiana branca e depois se crê traído, são muitas. Shakespeare tirou o argumento principal de Giraldi Cínthio, na obra Hecatommithi, publicada em 1565 na Inglaterra, mas utilizou também a História do Mundo, de Plínio, traduzida por Philemon Holland em 1601, a História Geográfica da África, de Leo the African, e o livro de Lewis Lewkenor sobre a constituição de Veneza. Considerada uma das grandes tragédias do autor, ao lado de Hamlet, Macbeth e Rei Lear, Otelo é uma obra que jamais saiu do repertório, mas que teve uma trajetória atribulada de adaptações e cortes até que o texto ficasse mais claramente fixado - como, de resto, grande parte do cânone shakespeariano.

$\mathrm{Na}$ Inglaterra, após um período de fechamento dos teatros pelos puritanos (1642-1660) o modelo teatral francês também acabaria triunfando sob Charles II, no período da Restauração. A partir daí, várias das peças de Shakespeare foram revistas e reescritas por dramaturgos como Dryden, Davenant e mesmo David Garrick, o grande ator do século XVIII (que, entretanto, nunca convenceu como Otelo, sendo mais bem sucedido no papel de lago). A opinião que se generalizou era a de que Shakespeare havia sido um grande poeta, porém um dramaturgo menor, exemplar de um tempo que ainda não conhecia o bom fazer teatral. É uma idéia presente inclusive no célebre prefácio de Samuel 
Johnson à edição das Obras Completas em 1765 (por mais elogioso que ele seja em certos aspectos).

Nesse mesmo período, inúmeros dramaturgos franceses traduziram e/ou adaptaram peças shakespearianas para o público francês. Entre eles, podemos citar Antoine La Place e Le Tourneur. O primeiro, ao "traduzir" Othello em 1745 - para ser lido, não encenado -, corta aproximadamente um terço de todo o texto, retirando as cenas "desnecessárias", "indecentes" ou "muito triviais". Com isso, Desdêmona transforma-se em uma mulher lacrimosa e o papel de lago diminui sensivelmente. Além disso, a tradução é muito ruim, já que La Place não domina bem a língua inglesa e acaba cometendo erros crassos. Em sua explicação para a tradução, La Place lembra ao leitor o fato de que certos "defeitos" do dramaturgo provêm do próprio caráter do povo inglês: o gosto pela catástrofe, pelo sangue, pelas mudanças de cena, pela baixa comédia. Referindo-se a seu método de tradução das obras shakespearianas, ele explica:

"[o objetivo foi] retirar, após análise, tudo o que não remeta diretamente à ação, e ao interesse, em suas tragédias; e me fixar em todas as cenas e situações passíveis de uma tradução tolerável, para aqueles que não podem por si próprios conhecer as belezas verdadeiras do original."”8

$\mathrm{Na}$ verdade, além de misturar alexandrinos com prosa de forma aleatória ao passar para o francês os versos brancos shakespearianos, La Place faz não uma tradução da obra, mas uma versão mais "aceitável", e um tanto verborrágica, da mesma para o seu público. Em termos de modificações, em Othello, a personagem do bobo é cortada; o primeiro ato é razoavelmente fiel, sem resumos de cena e com poucas omissões, mesmo que haja cortes e modificações; a seguir, como indica Gilman:

"Os atos II e III, apesar de relativamente acurados, são reduzidos em duração pela supressão de, respectivamente, 375 linhas de um total de 766, e de 294 de 842; e os atos IV e V não só têm eliminadas 452 linhas

\footnotetext{
${ }^{8}$ Apud GILMAN, Margaret. Othello in French. Paris, s/e, 1925, p. 6.
} 
de 711, e 149 de 606, mas são apresentadas em grande parte em alguns dos piores alexandrinos já escritos." ${ }^{9}$

Algumas das cenas perdem suas falas, havendo apenas uma descrição da ação dramática. Ao todo, La Place elimina passagens de três tipos: aquelas que parecem desnecessárias à ação central (por exemplo, II, i, 247-345, entre lago e Rodrigo; a cena do bobo, III, i); cenas indecentes para o público francês (como as entradas de Bianca, ou a cena em que Cássio se embebeda, II, iii, 29-185); e cenas muito triviais ou frívolas (exemplos dados pelo tradutor: II, i, 115-202, em que lago e Desdêmona aguardam a chegada de Otelo, ou mesmo a cena de Desdêmona cantando a Willow Song). Dessa forma, a peça fica mais próxima dos padrões clássicos, ainda que à custa de, não custa lembrar, quase um terço de seus versos. Já na época de sua publicação a tradução de La Place suscitou desagrado, como a do próprio Voltaire, ele mesmo um ferrenho crítico da "selvageria" de Shakespeare.

Já Le Tourneur, em 1776, realmente traduz a obra completa de Shakespeare, desculpando-se por reproduzir algumas passagens vulgares. Não por acaso, sua obra Shakespeare é dedicada a Luís XVI, um rei mais tolerante a idéias novas que seus predecessores. Ao contrário de La Place, Le Tourneur tenta manter as imagens poéticas do original, sem resumir ou omitir trechos. Por outro lado, ele inclui várias indicações de cena e notas explicativas, em uma edição que visa mais educar do que divertir. Ele também adiciona continuamente palavras no meio do texto, tornando a tradução demasiadamente longa e bombástica.

Le Tourneur escreve ainda um polêmico prefácio em defesa de Shakespeare, afirmando que a grandeza natural do autor inglês havia sido obscurecida por traduções anteriores pouco fiéis. O alvo, está claro, era La Place, cuja obra é um exemplo da linha de tradução então em voga, a belle infidèle - que pretende modificar o texto original tanto quanto necessário, segundo 0 julgamento do tradutor, de acordo com o "bom gosto" da cultura de recepção da tradução. Le Tourneur já chama a atenção para a relatividade da noção de

\footnotetext{
${ }^{9}$ GILMAN, Margaret. Op. Cit., p. 8 .
} 
"bom gosto" em termos culturais, uma visão que ainda demoraria um pouco para se tornar hegemônica na França. De qualquer modo, como afirmam Delisle e Woodsworth, Le Tourneur apresenta Shakespeare como uma opção à literatura francesa da época, "inaugurando uma tradição crítica da qual um dos exemplos famosos é a obra de Stendhal, Racine e Shakespeare (1823)". ${ }^{10}$

Além disso, podemos lembrar novamente o grande dramaturgo do século XVIII na França, Voltaire, que após um período morando na Inglaterra retornou à França e acabou por traduzir e adaptar obras do inglês - sua Zaïre é inspirada em Otelo, como veremos posteriormente, e ele também retomou o Júlio César shakespeariano nas obras La Mort de Cesar e Brutus. Voltaire foi um crítico feroz de Le Tourneur, o que não impediu que a tradução deste fosse um sucesso, um paradigma por quase cinqüenta anos tanto para outros tradutores quanto para produções cênicas, coexistindo com as versões de Ducis, de quem trataremos em seguida.

De toda maneira, um novo e acabado modelo de tradução, cuja função seria trazer a obra da forma prevista pelo autor original para os falantes de uma outra língua só viria a se impor com força total com a geração romântica, influenciada pelos teóricos alemães. Com Alfred de Vigny (1797-1863) e Émile Deschamps (1791-1871), uma nova tradução de tragédia em versos se estabeleceria na França, com o modelo alternativo em prosa sendo executado por François-Victor Hugo, o filho de Victor Hugo que empreenderia a tradução das obras completas de Shakespeare quase que palavra por palavra.

A influência das versões francesas se estenderia além das suas fronteiras, não apenas na Europa do sul - Itália, Portugal e Espanha - e suas respectivas colônias, como também em outras direções, chegando até a Rússia. A descoberta do Shakespeare original, em inglês, seria heterogênea, variando de país a país.

\footnotetext{
${ }^{10}$ DELISLE, Jean \& WOODSWORTH, Judith (eds.) Translators Through History. Amsterdam, John Benjamins Publishing Co., 1995, p. 76.
} 


\title{
1.2 - PORTAS DE ENTRADA NA CENA NACIONAL
}

\subsection{1 - O TEXTO DE DUCIS E A TRADUÇÃO DE GONÇALVES DE MAGALHÃES}

\author{
"Se o povo sabe o que é o Hamlet, Otelo, \\ deve-o ao reflexo gelado de Ducis. \\ Contudo, seria fácil apresentar-se no Teatro de S. Pedro \\ alguma coisa de melhor do que isso;" \\ Álvares de Azevedo, 1851.
}

Entre os muitos "corretores" do bardo inglês na França do século XVIII, há um dramaturgo que nos interessa mais de perto, porque sua obra chegará, no século seguinte, ao Brasil, com grande repercussão: Jean-François Ducis.

Dramaturgo francês do final do século XVIII, Ducis não sabia inglês, e conheceu Shakespeare através das traduções de La Place e de Le Tourneur. Ducis se encantou com as obras shakespearianas, apesar de todos os seus "defeitos" do ponto de vista francês, ainda ligado aos preceitos do classicismo, com as regras das unidades e das conveniências, o horror à mistura de gêneros e à apresentação de cenas violentas ou vulgares. Nesse momento os franceses, a começar por Voltaire, já achavam Shakespeare um bom poeta, mas um péssimo dramaturgo. E Ducis fez então o que outros vinham fazendo (de novo, a começar por Voltaire): tentou adaptar os enredos shakespearianos às regras clássicas do bem fazer teatral. Note-se que esse mesmo tipo de revisão também estava sendo feito na Inglaterra, e que o texto do Folio só viria a ser novamente a versão utilizada no palco em meados do século XIX, após a explosão romântica.

Ducis começou adaptando Hamlet, mas também produziu versões de Romeu e Julieta, Macbeth, Rei João e Otelo. Ele começou a trabalhar no Othelo em 1783, concluindo-o entre 1788 e 1790. A primeira encenação, pelos Comédiens, foi no Théâtre de la Republique, com estréia em 26 de novembro 
de 1792, tendo no elenco Talma (Othelo)", Dival (Pézare) e Mlle. Desgarcins (Hédelmonde), e suscitou muita polêmica.

De qualquer modo, esta foi a versão canônica na França até a encenação da tradução de Vigny, em 1829, e continuaria sendo representada em Paris até 1849, mesmo que, de início, a peça duciana não tenha sido exatamente popular:

“(...) a primeira performance não foi bem aceita. No $5^{\circ}$ ato, toda a platéia levantou em desordem e começou a protestar. Várias damas desmaiaram. E qual foi o resultado? Para acalmar o mais nervoso dos espectadores, Ducis imediatamente compôs um final alternativo - um final de paz e felicidade completas. Mas o grande ator Talma, que criou o papel de Othelo, não se importava muito com a personagem. Após uma apresentação em que surgiram algumas risadas inesperadas, ele se recusou a fazer a peça novamente - e isto apesar do fato de Madame de Staël nos dizer que 'era suficiente para ele franzir o cenho, passar a mão pela testa, para se tornar o Mouro de Veneza'. Foi apenas no final da vida, em 1825, que Talma concordou em remontar a tragédia. Nesse intervalo, o público tinha se acostumado mais ao enredo e às personagens graças às óperas italianas calcadas no assunto."11

As modificações de Ducis começam pelo nome das personagens. Na peça, o único nome que é mantido do original é o do próprio Othelo. Para, principalmente, facilitar as rimas exigidas pelas regras neoclássicas francesas, Desdêmona transforma-se em Hedelmonda, lago em Pézaro, Cássio em Loredano, Emília em Hermance e assim por diante. O número de personagens cai de dezesseis para sete, e suas relações diferem. Aqui, não vemos ligação profissional entre Othelo e Pézaro: eles são apenas amigos. Também não há ligação entre Pézaro e Hermance (em Shakespeare, lago e Emília são casados). Quanto a Loredano, ele não conhece Othelo e Pézaro; é filho de Moncenigo, o doge de Veneza, envolvido na trama de outra forma. Além disso,

\footnotetext{
* Além de ser o criador do papel, Talma escolheu Othelo como sua peça de despedida, ao retirar-se dos palcos em 1825 .

${ }^{11}$ SMET, Robert de. "Othello in Paris and Brussels". In Shakespeare Survey, vol. 3. Cambridge, CUP, 1950, p. 99.
} 
o texto todo é composto em versos alexandrinos com rimas AABBCC (a tradução de Gonçalves de Magalhães não segue o esquema de rimas original, e escolhe o decassílabo) e as unidades de ação, tempo e espaço (apenas Veneza) são respeitadas. Para enobrecer os elementos do entrecho, o lenço de Desdêmona transforma-se em diadema, e a jovem não é asfixiada, mas apunhalada. O papel de lago é fortemente diminuído, segundo Ducis, porque

\begin{abstract}
"Estou persuadido que se os ingleses podem observar as manobras de tal monstro sobre a cena, os franceses não poderiam nem por um momento suportar sua presença, e menos ainda vê-lo desenvolver toda a profundidade de sua monstruosidade... a impressão predominante de horror que ele inspiraria amortizaria o interesse e a compaixão que eu queria chamar sobre a amante de Othello e sobre este bravo e desventurado Africano. Foi assim com uma intenção determinada que escondi de meus espectadores esse caráter atroz, para não os revoltar."12
\end{abstract}

Em termos de enredo, temos também muitas mudanças. Para começar, não seguimos um plano de lago para vingar-se do general Otelo, que preferira promover Cássio a ele na escala militar. No primeiro ato, o pai de Hedelmonda, Odalberto, dirige-se ao Senado de Veneza para protestar contra Othelo, que Ihe roubara a filha. Este justifica o envolvimento de ambos com idéias semelhantes às do texto shakespeariano, mas há algumas diferenças básicas. Em primeiro lugar, a acusação de Brabâncio incluía uma insinuação de feitiçaria, iniciando toda uma problemática da palavra encantatória que permeará o discurso do protagonista na obra toda. Além disso, no texto de Ducis, Hedelmonda ainda não se casou com Othelo, apesar do pai não saber desse fato a princípio. Finalmente, em Ducis, o problema da aceitação do casamento por parte de Odalberto constituirá um foco central do enredo. $\mathrm{O}$ ato inclusive termina com o casal discutindo sobre um possível perdão de Odalberto no futuro, trocando juras de amor e fazendo planos para o casamento.

\footnotetext{
${ }^{12}$ DUCIS, Jean-François. Othello, édition critique par Christopher Smith. Exeter, University of Exeter Press, 1991, p. 3.
} 
No ato II, começamos com uma cena típica do Neoclassicismo: a personagem Hermance, aia de Hedelmonda, serve de "escada" para que a heroína revele ao público todos os seus sentimentos e temores. Ela julga estar fazendo algo errado ao decidir desposar Othelo, e se recorda da perda da irmã e da mãe. Esta, definhando no leito de morte, dissera à filha que esta morreria desgraçada, que este era o seu destino. Por isso, Hedelmonda está desesperada. Hermance tenta acalmá-la, até que chega ao palácio de Othelo o jovem Loredano. Hedelmonda não o conhece, mas ele é filho do doge, e vem angustiado pedir a ela que interceda junto ao futuro marido para the conseguir um lugar entre os guerreiros que defendem a cidade, já que seu objetivo é morrer. O moço comenta que Odalberto, cego de cólera, pretende atacar o Senado mesmo que tal gesto lhe custe a vida. Hedelmonda, transtornada, pede a Loredano que salve seu pai. Tocado, ele parte com essa missão. Sua saída é vista por Othelo e Pézaro. A princípio, Othelo não desconfia do jovem; sua preocupação continua sendo obter o perdão e o consentimento de Odalberto para casar-se. Porém, Pézaro Ihe fala das paixões dissimuladas em Veneza e o aconselha a apressar as bodas.

$O$ ato seguinte se inicia com Hedelmonda e Hermance discutindo o caso de Loredano. A aia sugere a Hedelmonda que não comente sobre o moço com Othelo, para não the despertar ciúme. Loredano chega com notícias inquietantes de Odalberto, e diz temer que ele traia o Estado. A jovem não acredita que o pai faça isso, e inquire o jovem sobre seu desejo de morrer e sua origem. Loredano explica que fora criado por um estrangeiro e que, tendo sabido das vitórias de Othelo, viera a Veneza e se encantara com Hedelmonda. Sabendo, porém, que ela ama e é amada, prefere a morte. A jovem se assusta com a ousadia do rapaz, que admite seu erro e vai se retirando. Ao ver, contudo, a chegada de Odalberto, fica escutando a conversa. Odalberto acusa a filha por sua desgraça, e a lembra de sua dedicação de pai. Ela se compadece, mas reluta quando o pai lhe propõe um plano. Ao ver a reação da moça, Odalberto se irrita e ordena que ela assine um bilhete, ameaçando suicidar-se. Hedelmonda, então, assina o papel sem ler. O pai, satisfeito, diz a ela que o céu the confiara um excelente jovem, que a ama: o filho do doge, Loredano. Este reaparece e se identifica. Odalberto abençoa este enlace, mas 
Hedelmonda recua - apesar de dever tudo ao pai, é Othelo quem ela vê como marido. Irado, Odalberto Ihe entrega o bilhete e a repudia ao sair. Nesse momento, Hermance traz notícias de que o Conselho de Veneza quer punir Odalberto, talvez até com a morte. Desesperada, Hedelmonda pede a Loredano que interceda junto ao doge, e dá a ele o bilhete e o diadema que usa (presente de Othelo). O jovem concorda em ajudá-la, mas sai advertindo que não responde por si depois, pois seu coração está confuso e ciumento. Othelo surge, chamando Hedelmonda: o altar está pronto. Temerosa, ela quer adiar o casamento, que acaba não se realizando: um estranho tenta roubá-la, como ficamos sabendo depois.

Devemos lembrar que 0 terceiro ato era 0 centro da engrenagem shakespeariana, o ato no qual lago começava a distorcer a mente de Othello (cena III). Aqui, temos também ações centrais para a trama de Ducis tal qual foi composta, e o envolvimento maior de Pézaro só ocorrerá no ato seguinte.

No quarto ato, Othelo questiona Pézaro sobre quem pode ter querido impedir o casamento. Ambos se lembram da presença escusa de Loredano em outra situação, mas desconhecem sua identidade. Othelo não crê que Hedelmonda o trairia. Pézaro vai inquirindo Othelo até que este admite que estranhara um estremecimento da jovem e a ausência do diadema que lhe dera. Pézaro, então, atiça o ciúme do companheiro:

"PÉZARO - Teme o ciúme, meu prezado Othelo!

OTHELO - Tão vil tormento cuidas que me agita!

Eu procuro a verdade tão somente.

Dize, crês tu que no furor que o anima,

Esse jovem um rapto meditasse?

Nada me ocultes, fala; então que pensas?

Será ele?

PÉZARO - O amor vence a virtude;

Seu poder nos arrasta, e a queda é fácil.

Tremes, Othelo?...

OTHELO - Quem? Estou tranqüilo...

Crês pois?... 
PÉZARO - Que é ele só que neste dia

Ultrajou teu amor com sua audácia.

OTHELO - Se Hedelmonda infiel deu o diadema

Ao meu rival... Nossos leões dos ermos,

Em furor, nos seus antros abrasados,

Os viajores trêmulos despedaçam;

Melhor fora para ele que os famintos

Leões em mil pedaços the espalhassem

As palpitantes carnes do que agora

Vivo cair em minhas mãos terríveis."13

Ducis se vale aqui de um dos trechos mais citados de Shakespeare, encontrado na peça em III, iii ("O, beware, my lord, of jealousy;/ It is the green-ey'd monster, which doth mock/ The meat it feeds on"14), embora deslocado e simplificado. Suas implicações, contudo, continuam similares: alimentar o ciúme do protagonista alertando-o contra ele. Aqui também Ducis apresenta a imagem que vai se perpetuar em associação com Othelo: a do leão, metáfora do africano feroz.

Pézaro aconselha Othelo a sair de Veneza com Hedelmonda e promete matar Loredano se o vir. Sozinho, Othelo exalta a amizade de Pézaro e fala sobre suas dúvidas. Hedelmonda chega com Hermance e pede ao amado que a deixe procurar o doge para salvar seu pai. Othelo reluta, temeroso. Hedelmonda se surpreende, tristemente, e Hermance a defende, até que Othelo capitula, reconhecendo seu erro e seu ciúme. Ao sair, Hedelmonda reafirma a ele seu amor e sua fidelidade. Sozinho novamente, Othelo reflete sobre a virtude da jovem. Pézaro retorna, conta que encontrara Loredano e que, após feri-lo, descobrira com ele o diadema e uma carta:

"PEZARO - (...) Eil-a. Esta carta

(sejamos mais senhores de nós mesmos)

Talvez a prova seja da perfídia.

OTHELO - (estupefato) enfim, eu reconheço que ultrajei-te.

\footnotetext{
${ }^{13}$ MAGALHÃES, D.J.G. Obras de D.J.G. de Magalhães - Tomo III - Tragédias. Rio de Janeiro, Livraria de B.L. Garnier, 1865, pp. 319-320.
} 
(lendo) "Meu pai, a mão de Othelo renuncio.

Acalme o meu pesar as vossas iras.

A vós pertence só dar-me um esposo.

Hedelmonda."... É possível!"15

A princípio, Othelo pensa em matar-se, depois em matar a amada junto ao suposto amante, mas hesita. Hedelmonda aparece ao ouvir a discussão entre os dois homens, e Othelo a trata ironicamente. Feroz, ele sai com o amigo, e Hedelmonda reflete sobre tamanha mudança.

No último ato, Hedelmonda está em seu quarto. Hermance a questiona sobre as causas de seu medo, mas a jovem só fala em sensações e pressentimentos ligados à morte de sua própria mãe. Ela tenta tocar harpa (uma referência à cena do salgueiro, em Shakespeare?), mas desiste ao ouvir o início de uma tempestade. Hermance a deixa e ela adormece. Othelo entra, ainda refletindo sobre o que fazer. Hedelmonda acorda, assustada, e explica a Othelo que dera o diadema a Loredano para ajudar Odalberto. Ela nega amar o jovem, mas admite que ele a ama. Ela reafirma, entretanto, seu amor por Othelo, que não Ihe dá crédito e the mostra o bilhete. Hedelmonda vê-se perdida e Othelo, mostrando um punhal, ordena-Ihe que se prepare para morrer. Em vão, ela argumenta que assinara o papel sem o ler. Othelo conta a ela que Loredano morrera em duelo com Pézaro. A moça o lamenta, o que enfurece Othelo ainda mais. Transtornado, ele a apunhala e a esconde no leito.

Hermance traz notícias sobre a prisão de Pézaro. Entram Moncenigo, Loredano (que na verdade não morrera), Odalberto e outros, explicando que Pézaro amava Hedelmonda e tinha um plano para roubá-la. Othelo vê que fora enganado. Loredano conta que intercedera junto a Odalberto e que este finalmente perdoara a filha e seu amado. Contudo, Hermance descobre o corpo de Hedelmonda, e Othelo, em desespero, reconhece seu erro e se mata.

\footnotetext{
${ }^{14}$ SHAKESPEARE, W. The Complete Works. London, Atlantis, 1980, p.832.

${ }^{15}$ MAGALHÃES, D.J.G. Op. Cit., p. 330.
} 
Algumas edições do texto de Ducis incluem também o final feliz que ele criou em 1793, um ano após a estréia da peça, alternativo ao do texto original. Ducis o compôs a contragosto, pressionado pela opinião popular que achava o final original terrível demais. Nele, Moncenigo, Loredano e Odalberto chegam a tempo para salvar Hedelmonda e explicar a Othelo a atitude de Pézaro. Othelo se arrepende e renova seu compromisso para com a jovem e com o Estado. A tradução de Gonçalves de Magalhães não traz essa versão, mas apresenta um monólogo final alternativo para Othelo, monólogo este que não está presente em nenhuma das duas edições francesas consultadas:

\footnotetext{
"Morta!... morta!... e sou eu que Ihe abro a campa!

Oh vítima inocente!... oh ímpio amigo!...

Oh mil vezes cruel, brutal Othelo!

E pude perpetrar tão feio crime!

Que falsário infernal!... Que homem! Que monstro!

Quem viu jamais tão negra atrocidade?

Oh Pezaro, oh algoz de minha dita!

Por que não vens a mim? Por que me foges?

Com que prazer te retalhara o peito

Com este ferro, que roubou-me a esposa!

Oh Hedelmonda! Oh vítima de um tigre!

Fujam todos de mim... odeio tudo...

Tudo me causa horror... só quero a morte.

(mata-se)." ${ }^{16}$
}

Um dos principais problemas do texto de Ducis é a falta de seqüência dramática; aparentemente, o dramaturgo estava mais interessado em fazer uso de sentimentos presentes em Shakespeare do que em manter a ação dramática em si. Falta uma seqüência lógica e coerente, em especial, ao terceiro ato, com suas reviravoltas e sua quantidade de informação. Com tudo isso, Ducis compromete as justificativas e os objetivos das personagens, e sua peça se torna um drama moral sobre uma filha desobediente. Décio de Almeida Prado a consideraria uma versão classicizada e domesticada do original ${ }^{17}$.

\footnotetext{
${ }^{16}$ Id. Ibid., p. 362.

${ }^{17}$ PRADO, Décio de Almeida. História Concisa do Teatro Brasileiro. São Paulo, EDUSP, 1999, p. 38.
} 
Mesmo assim, a peça de Ducis, na época, seria considerada mais equilibrada do que a de Shakespeare, tornando-se a mais popular na França até 1860 - ou seja, mantendo seu fôlego em Paris inclusive através do período romântico e além, após a tradução de Vigny e a estréia da ópera de Rossini sobre o mesmo tema, e chegando também aos palcos de Portugal e do Brasil. 


\title{
1.2.2 - A ENCENAÇÃO DE JOÃO CAETANO PARA O TEXTO DE DUCIS
}

\author{
“João Caetano foi, para o Brasil, no princípio de sua \\ carreira artística, o que Edmundo Kean fora para a Inglaterra: \\ a escola da natureza, o esforço individual, a luta contra os preconceitos, \\ o gênio a abrir caminho." \\ Pires de Almeida
}

Se, no geral, devemos tomar as palavras de Pires de Almeida com cautela, como, aliás, veremos ao longo do capítulo, na afirmação acima devemos darIhe crédito. João Caetano não apenas criou a primeira companhia dramática brasileira como desenvolveu uma carreira de sucesso que mesclou repertório europeu com o lançamento de autores nacionais, uma carreira na qual o estudo de manuais franceses - como demonstrou Décio de Almeida Prado em suas obras sobre o artista - se uniu a uma profunda intuição para criar um estilo de interpretação muito diferente daqueles trazidos pelas companhias portuguesas em suas vindas ao Brasil a partir da fixação, no Rio de Janeiro, da família real portuguesa, entre 1808 e 1815. Nessa trajetória artística, a tragédia de Ducis desempenharia papel superlativo.

Em terras nacionais, a obra de Ducis se popularizaria com a interpretação de João Caetano entre 1837 e 1860, que encomendou a tradução do texto a Gonçalves de Magalhães. Este seria realmente o seu maior sucesso, o papel com o qual ele seria identificado por muito tempo, e que the traria glória duradoura. Tanto que, se outras peças tiveram no geral menos de seis apresentações, Othelo foi levado à cena 26 vezes, um número admirável para a época. E isto, note-se, apenas no Rio de Janeiro; João Caetano também apresentaria seu Othelo na Bahia, em Pernambuco e no Rio Grande do Sul.

Os próprios jornais do período, nos quais ainda é muito rara a publicação de críticas teatrais, ressaltam a peça, como demonstra o comentário do Jornal do Comércio: 
"É sempre com grande prazer que o público corre a ver uma tragédia, em que entra o Sr. João Caetano: este nome tem se tornado célebre entre nós, pelo talento original do jovem ator, que assegura o sucesso de qualquer drama. Seu gênio revelou-se todo inteiro no Poeta e a Inquisição e no Othelo; no primeiro, mostrou a variedade difícil daquela composição sublime, parto de um gênio brasileiro; no segundo, mostrou a força e a veemência de um caráter ciumento." 18

Othelo parece ter sido importante não apenas para João Caetano, mas também para Gonçalves de Magalhães. Tanto que, apesar de ter traduzido outras peças para a companhia do ator carioca, Magalhães inclui apenas Othelo nas suas Obras Completas, no volume Tragédias (tomo III). No prefácio, ele justifica a inclusão da tradução por ela ter sido um pedido de João Caetano, por ela já ter sido impressa em 1842, e por já ter sido tão representada. André Gomes chama a atenção para o fato da dramaturgia de Ducis, com seu espírito cauteloso, ter influenciado a produção do próprio Magalhães, tanto em Antônio José ou o Poeta e a Inquisição, peça na qual o tratamento dado ao envolvimento entre o judeu e Mariana é "por demais timorato", quanto em Olgiato, na qual o tirano Galeano Sforza simplesmente não entra em cena (evocando os motivos que Ducis elencara para quase suprimir lago-Pézaro de sua obra: não incomodar o espectador nem ofender a moral). A conseqüência é, como em Ducis, a preponderância dos discursos em detrimento da ação ${ }^{19}$

Mas a peça seria invariavelmente identificada, em primeiro lugar, com o ator que a protagonizou, logo no início de sua carreira. Por que uma escolha tão ousada de um ator sem tanta experiência? Décio de Almeida Prado, comentando sobre a peça e sobre a escolha de João Caetano em representála, afirma:

\footnotetext{
${ }^{18}$ Jornal do Comércio, 19 e 20/03/1839, pp. 2-3. O artigo é uma apreciação da encenação da tragédia Oscar.

${ }^{19}$ GOMES, André L. As Marcas de Nascença - A Contribuição de Gonçalves de Magalhães para o Teatro Brasileiro. Dissertação de Mestrado. São Paulo, FFLCH/USP, 1998, pp. 110-111.
} 
"Hamlet, que Lekain se recusara a representar por julgá-lo pouco ortodoxo moral e literariamente, é de 1769. Otelo, de 1792. Mas ambas as tragédias chegaram ao século dezenove rejuvenescidas pela extraordinária interpretação de Talma, que extraiu delas todo o substrato shakespeariano não eliminado por Ducis. E não era tão pouco assim: do príncipe de Dinamarca, permanecera a silhueta romântica de um adolescente estarrecido pelo confronto com o espectro paterno, minado pela melancolia, pela dúvida, pela insegurança, pelo cansaço de viver; do Mouro de Veneza, a história patética do negro enamorado por uma branca, com o seu ciúme doentio, a sua força selvagem, a sua violência quase animal.

"O alvo de João Caetano, ao viver um e outro papel, não era talvez Shakespeare, menos ainda Ducis: a legenda de Talma, falecido pouco antes, em 1826, é que deveria fasciná-lo. Não se pode imaginar maior atrevimento, por parte de um ator tão em começo de carreira, do que esse desafio lançado ao 'monstro sagrado' da tragédia. É um gesto que só se compreende num país de riquíssima tradição teatral, como a Inglaterra, onde os atores já nascem representando Shakespeare, ou então no Brasil, onde a própria ausência de tradição abre campo para todas as aventuras, desde que haja coragem e ambição, qualidades, Deus seja louvado, que nunca faltaram ao nosso João Caetano. (...) O Otelo (...) constitui-se na interpretação de maior prestígio artístico de todos os seus trinta e tantos anos de teatro." 20

O foco em Talma é confirmado no Ano Biográfico Brasileiro, no qual Macedo conta que Magalhães escrevera no álbum de João Caetano os seguintes versos:

"Os vôos de Talma, com quem sonhas,

Avante segue escurecendo, a inveja

Que já nem ousa disputar-te a glória!"21

\footnotetext{
${ }^{20}$ PRADO, Décio de Almeida. João Caetano. São Paulo, Perspectiva/EDUSP, 1972, pp. $27-28$.

${ }^{21}$ MACEDO, J. M. de Anno Biographico Brazileiro. Rio de Janeiro, Typografia e Lithografia do Imperial Instituto Artístico, 1876, vol. 1, p. 512.
} 
A ousadia do ator na escolha comprovaria ser adequada, como demonstra 0 sucesso alcançado. O próprio João Caetano admite a importância do papel em sua carreira - que posteriormente se centraria mais no melodrama francês. Tanto que o número de vezes em que ele usa o papel para dar exemplos concretos em seu Lições Dramáticas é bastante alto, em comparação com outras peças. Alguns trechos podem surpreender aqueles sem intimidade com o texto de Ducis, como o seguinte, que trata da distância que o ator deve manter da personagem:

"Representando eu a tragédia Otelo, no $5^{\circ}$ ato, na força do maior ciúme, cólera e desespero, sempre que apunhalava Hedelmonda e a atirava sobre o leito, tinha o maior cuidado, não só em não a magoar, como em deitá-la de maneira que ficasse decente aos olhos do espectador; entretanto tinha a idéia clara para me recordar disto, e não esfriava a paixão que estava pintando: em seguida caindo arquejante sobre uma cadeira e batendo fortemente com o punho cerrado sobre a mesa, proferia as seguintes palavras: - Eu fiz o que devia! - mas com tanta unidade na ação, que ninguém se havia de persuadir que eu me havia lembrado de não magoar a dama e de deitá-la decentemente". 22

Outros bons exemplos se evidenciam quando ele se refere a seu trabalho vocal. No primeiro caso, calcado fortemente nos manuais franceses que the serviram de $\operatorname{apoio}^{23}$, falando detalhadamente da composição das pausas nas falas:

"Seja a primeira fala do Mouro de Veneza, na tragédia Otelo:

'Eu me calo, Odalberto,'

um quarto de respiração, porque o pensamento fica suspenso.

'Eu não respondo'

inteira porque termina a cláusula.

'Mas se já quando eu fui amigo vosso'

um quarto, porque fica suspenso o pensamento.

\footnotetext{
${ }^{22}$ SANTOS, João Caetano dos. Lições Dramáticas. Rio de Janeiro, Serviço de Documentação - MEC, 1955, pp. 11-12.

23 Vide PRADO, Décio de Almeida. João Caetano e a Arte do Ator. São Paulo, Ática, 1984, especialmente pp. 104-110.
} 


\title{
'A terra em que nasci me perdoastes'
}

meia respiração, porque quase que termina a cláusula.

'Eu vos rogo que agora em minha fronte'

uma respiração imperceptível, porque deve quase ligar o pensamento ao que se segue.

\section{'Meus remorsos vejais'}

meio quarto de respiração porque suspende um pouco a cláusula para descer rapidamente ao final

\section{'Não vossa injúria'}

com que exprime bem o pensamento, e ao finalizar toma uma respiração inteira.

Observando este método até terminar a fala, qualquer um conservará a mesma força com que começou sem se fatigar". ${ }^{24}$

E no seguinte, referente ao timbre de voz:

\begin{abstract}
"Lembro-me ainda que quando me encarreguei do papel de Otelo, na tragédia $O$ Mouro de Veneza, depois de ter dado a este personagem o caráter rude de um filho do deserto, habituado às tempestades e aos combates, entendi que este grande vulto trágico quando falasse devia trazer à idéia do espectador o rugido do leão africano, e que não devia falar no tom médio da minha voz; recorri por isso ao tom grave dela e conheci que a poderia sustentar em todo o meu papel; fiz um exercício apurado para lhe ajustar todas as inflexões naturais e convenientes às variadas paixões que Otelo devia exprimir. Consegui bom resultado deste estudo, porque a voz me era natural; porém, todos os que depois representaram a tragédia, procuraram imitar o som da minha voz, e não podendo sustentá-la porque se valiam da voz contrafeita, não agradaram nunca." 25
\end{abstract}

Temos aí uma idéia da composição da personagem feita pelo ator, importante inclusive pois seria lembrada mais tarde por vários críticos e dramaturgos em seus escritos. As críticas feitas no período dão conta da repercussão da interpretação de João Caetano, como aponta Décio de Almeida Prado:

\footnotetext{
${ }^{24}$ SANTOS, João Caetano dos. Op. Cit., pp. 17-18.

${ }^{25}$ Id. Ibid., p. 29.
} 
“As primeiras representações, conta Macedo, causaram espécie, 'pela exageração dos impulsos apaixonados, pelos gritos ou rugidos selvagens e desentoados'. O modelo remoto destes 'rugidos selvagens' era o 'rugissement' de Talma." 26

Joaquim Nabuco também faz referência ao espetáculo:

"Otelo era exatamente o papel, segundo tudo faz crer, que mais se adaptava às faculdades de João Caetano. Estas eram de ordem física; as paixões que ele sabia expressar adequadamente, eram os grandes instintos do homem; a impressão que causava era magnética, um como que eflúvio da própria pessoa. A majestade do porte, a beleza máscula, sombria do rosto, a gravidade natural dos movimentos, a extensa sonoridade da voz, o brilho elétrico do olhar, a mobilidade incomparável da fisionomia, (...) qualidades, em suma, que podem fazer um grande Otelo eram as de João Caetano." ${ }^{27}$

Como explica Bárbara Heliodora ${ }^{28}$, João Caetano foi o primeiro - e por mais de um século, o único - grande ator brasileiro identificado com um papel shakespeariano - mesmo através de uma adaptação. Ela ressalta a popularidade do texto de Ducis, mas levanta a suspeita do ator ter encenado o Hamlet vindo do original inglês em 1835, seguindo a indicação dada por Pires de Almeida. É bom ressaltar que, quanto a Otelo e Hamlet, Pires de Almeida é bem claro na afirmação da encenação, por João Caetano, dos textos de Shakespeare. No caso de Otelo, temos:

"Insistindo, porém, João Caetano em apresentar-se de tez bronzeada, e não branca*, Magalhães, agastando-se, não assistia mais às

\footnotetext{
${ }^{26}$ PRADO Décio de Almeida. João Caetano. São Paulo, Perspectiva / EDUSP, 1972, p. 28. A fonte da citação de Macedo é MACEDO, J.M. Ano Biográfico, I, 513. A citação também se encontra em FARIA, João Roberto. Idéias Teatrais: o Século XIX no Brasil. São Paulo, Perspectiva / FAPESP, 2001, p. 60. Ali, o autor mostra que o ator não dá uma idéia de equilíbrio e naturalidade.

27 Apud MAGALDI, Sábato. Panorama do Teatro Brasileiro. Rio de Janeiro, MEC, Funarte, SNT, INL, $2^{\mathrm{a}}$ ed., s/d, pp. 65-66.

${ }^{28}$ ALMEIDA, Bárbara Heliodora. "Shakespeare in Brazil”, in Shakespeare Survey no. 20. Cambridge, CUP, 1967, p. 121.

* vale lembrar, uma questão muitas vezes polemizada em encenações européias até o final do século XIX.
} 
representações do Othello, o que levou o trágico fluminense a restituir-lhe a tradução, substituindo-a pela versão de igual nome, de Alfredo de Vigny, feita em 1830, e trasladada para a vernácula por J. C. Craveiro, a qual tivera sido primitivamente montada; razão por que, ainda hoje, põe-se em dúvida que João Caetano houvesse representado o Othello de Shakespeare, antes do de Ducis; acreditando-se, entretanto, que o preferido fora a acomodação de Alfredo de Vigny que, por não se distanciar de muito do original inglês, tem sido com ele confundido". ${ }^{29}$

As afirmações, algo confusas, são complementadas com um comentário sobre a superioridade do texto de Vigny sobre o de Ducis e com a conclusão de que, após reconciliar-se com Magalhães, João Caetano voltara à versão de Ducis. Nas imagens de Brazil-Theatro, Pires de Almeida identifica até as fotografias de João Caetano relativas aos dois Otelos, o shakespeariano e o de Ducis (vide anexos).

Quanto a Hamlet, Pires de Almeida é ainda mais enfático:

"Depois de Othello, o Hamleto, personagem enigmático e sombrio, que atravessa sempre, e a horas certas, o pensamento humano!... (...) Releva, entretanto, registrar quanto antes, que a tragédia levada ao palco, nessa data [a indicação, incorreta, é 1835], não foi a de Ducis, mas a de Shakespeare, vertida do inglês, creio, por Oliveira e Silva" ${ }^{30}$

Contudo, como demonstraria posteriormente Décio de Almeida Prado, as afirmações de Pires de Almeida não se confirmam:

"Não poderíamos falar do Otelo sem discutir, ainda que de passagem, o problema das relações de João Caetano com Shakespeare. Pires de Almeida, percebendo a relevância da questão para a fama póstuma do ator, insistiu em que este teria interpretado os próprios originais shakespearianos, contra o testemunho de todos os contemporâneos. O cuidadoso levantamento feito por Celuta Moreira Gomes em jornais da época deu os seguintes resultados: uma representação, em 1838, de $O$

${ }^{29}$ Brazil Theatro, $2^{\circ}$ fascículo 1903-1906, p. 622. 
Mercador de Veneza, tradução da peça Shylock, de Alboise e Du Lac, criada em Paris em 1830; uma representação do Macbeth, de Ducis, em 1843; seis representações do Hamlet, sem menção do autor, em 1843 e 1844; e vinte e seis representações do Otelo, de 1837 e 1860. Não é difícil determinar a autoria do Hamlet. João Caetano, relembrando nas Lições Dramáticas a sua interpretação, escreveu: "na magnífica cena em que ele [Hamlet], abraçado com a urna fala às cinzas de seu pai, um frio tremor se apoderou de mim (...)". Ora, esta famosa cena da urna funerária, inexistente em Shakespeare, constitui o clímax da tragédia de Ducis. Quanto ao Otelo, todas as vezes em que figura nos anúncios o nome do autor ou de alguma personagem que permita identificá-lo, trata-se da tragédia traduzida por Gonçalves de Magalhães, não sendo crível que João Caetano intercalasse estas versões de Ducis com outras do próprio Shakespeare sem chamar a atenção para o fato nos jornais.

"Sempre, portanto, que procuramos Shakespeare em João Caetano acabamos por encontrar, com uma única e pouco significativa exceção, Jean-François Ducis, escritor cujo ingrato destino foi o de ter sido considerado excessivamente audacioso pelo século dezoito e excessivamente timorato pelo dezenove." ${ }^{31}$

Bárbara Heliodora também comenta, assim como outros críticos, que os excessos de Ducis são ridicularizados por outras pessoas, que conheciam a qualidade superior do texto de Shakespeare (seu exemplo é Martins Pena). O mesmo aconteceria com a interpretação romântica e exagerada de João Caetano, muitas vezes ao mesmo tempo. Porém, não custa ressaltar que vários críticos de gerações posteriores reconheceriam na interpretação de João Caetano semelhanças com os estilos de Salvini e Rossi, os grandes trágicos italianos que encantariam o Rio de Janeiro na década de 1870.

\footnotetext{
${ }^{30}$ Id. Ibid., p. 624.

${ }^{31}$ PRADO, Décio de Almeida. Op. Cit., p. 25.
} 


\subsection{3 - OS OUTROS OTELOS DE JOÃO CAETANO}

\subsubsection{1- ZAÍRA, DE VOLTAIRE}

"Foi no teatro, foi no campo cultivado pelos Corneilles e Racines,
que M. de Voltaire adquiriu a maturidade
de sua grandiosidade e de sua glória".
J.F. Ducis

"[Shakespeare] tinha um gênio pleno de força e de fecundidade, de natural e de sublime, sem o menor traço de bom gosto e sem o menor conhecimento das regras".

Voltaire

Escrita em 1732, Zaíra não é a única obra de Voltaire que guarda relações com os escritos de Shakespeare, os quais o autor francês conheceu em sua estada na Inglaterra. Mas se em peças como A Morte de César a relação é direta com Júlio César, sendo aquela uma verdadeira adaptação da obra inglesa aos preceitos do classicismo, no caso de Zaíra os pontos de contato são mais tênues, ainda que claros, como poderemos perceber pelo enredo.

No primeiro ato, Zaíra e Fatime falam da condição de escravas. Fatime sonha com a liberdade, mas Zaíra acha que viver sob Orosmane é a sua realidade. Fatime a lembra de um francês que dissera que viria libertá-las. Mas já há dois anos que ele partira, e Zaíra aconselha a amiga a não se fiar em tal promessa, e acaba por the revelar o segredo do sultão: Orosmane pretende casar-se com ela. Fatime fica surpresa mas feliz, pois as virtudes de Zaíra merecem tal prêmio.

Contudo, Fatime lembra a Zaíra que sua origem é cristã. A amiga não quer falar disso, pois nem sabe se é verdade, já que não conhecera seus pais. Fatime Ihe conta que Néréstan, o francês, dissera que ela nascera de um ventre cristão, e além do mais uma pequena cruz fora encontrada com ela, a qual Zaíra continuou a carregar até aquele momento. Zaíra argumenta que não 
pode admitir um Deus que seu amor odeia; sempre viveu junto aos costumes muçulmanos, e só mais tarde soube da existência da lei cristã, que ela honra e admira, mas pouco conhece. Fatime a adverte que ela se tornará inimiga de todo o povo cristão ao se casar com aquele que o venceu. Zaíra admite que talvez, sem o amor, ela se tornaria cristã, e se sacrificaria. Mas pelo amor de Orosmane tudo foi esquecido.

O sultão entra para falar com sua amada sobre o casamento. Ele condena os costumes muçulmanos, como o de ter várias mulheres, e anuncia que ela será sua única esposa. Zaíra, por sua vez, declara também o seu amor.

Na cena III, Néréstan surge, anunciando que cumpriu a tarefa imposta a si pelo sultão; vem reclamar agora a sua recompensa, que consiste na libertação de Zaíra, Fatime, e de mais dez cavaleiros cristãos aprisionados, mesmo que ele próprio tenha que voltar à escravidão. Orosmane admira sua coragem, e se nega a receber o espólio que o jovem traz ou a aprisioná-lo. Diz que, em lugar dos dez cavaleiros, deixará que Néréstan leve cem, mas não abrirá mão nem do velho comandante cristão, Lusignan, nem de Zaíra. O francês tenta reclamar, mas Orosmane o adverte, e ele se retira. Zaíra e Fatime saem também, para logo começarem os preparativos para as bodas. Orosmane comenta, a sós com Corasmin, sobre os olhares de Néréstan para Zaíra.

No segundo ato, Néréstan lamenta que Zaíra pareça ter abandonado seu povo pelo sultão que a ama, e também a impossibilidade de resgatar Lusignan. Chatillon, um cativo, fala das glórias desse combatente, até sua derrota em Jerusalém. Néréstan se lembra de ter sido levado com as outras crianças, entre elas Zaíra. Chatillon sugere que o jovem peça a ela para interceder por Lusignan. Repentinamente, Zaíra aparece, tendo obtido permissão de Orosmane para falar com Néréstan. Reafirma a ele a amizade que vem da infância, na prisão, e a ligação que ambos têm desde o nascimento. Ela conta que quer proteger os cristãos e que convenceu o sultão a libertar Lusignan. Néréstan acaba por reconhecer a virtude do mouro. 
$\mathrm{Na}$ cena seguinte, Lusignan entra, sem poder crer que está livre. Zaíra the explica o acordo entre Néréstan e Orosmane. Néréstan conta suas aventuras. Lusignan também fala de seus feitos, e lamenta a sua ignorância sobre seus dois filhos, um menino e uma menina, aprisionados ali também. Prestando mais atenção nos jovens, vê a cruz que Zaíra traz e uma cicatriz de Néréstan, e os reconhece como seus filhos. Após um momento de alegria, Lusignan quer saber se a filha é cristã. Ela diz ter crescido sob as leis muçulmanas, o que desagrada ao pai. Ele conta a Zaíra tudo sobre o seu passado, seu nascimento e sua família. Acusando-a de blasfêmia, de ter traído o Deus por quem tantos morreram, suplica que ela diga que é cristã; Zaíra acaba por confessar que o é.

No terceiro ato, Orosmane e Corasmin conversam. O primeiro está satisfeito pois a França não pretende mais atacar Jerusalém, tendo voltado suas embarcações contra o Egito, cujo rei Méledin é inimigo pessoal de Orosmane. Assim, não há com o que se preocupar em termos militares. Volta a falar de seu amor por Zaíra, que o fez libertar Lusignan, e admite que a deixou falar mais uma vez com o jovem francês. Orosmane ordena a Corasmin que traga $o$ rapaz para falar com Zaíra, e se retira. Néréstan e Zaíra se encontram. Ele traz más notícias: Lusignan não resistira à emoção de rever os filhos, e acabara de falecer. Em seus últimos instantes, porém, duvidara da filha, e morrera perguntando se ela era cristã. A moça afirma que sempre foi cristã, mas que, criada na escravidão e sem quem a ensinasse, ignora a lei de Deus. Néréstan Ihe explica que essa lei ordena que ela odeie o império de seu senhor, e que ame a Deus e a Cristo. Diz que um sacerdote virá para tirar suas dúvidas e para batizá-la. Zaíra acaba contando ao irmão que ia se casar com Orosmane, já que os dois se amam. Néréstan não se conforma, mas acaba por perdoá-la já que, sem o batismo, o braço de Deus não estava ali para Ihe dar coragem e resistir. Porém, ele demanda que Zaíra não se case sem que, pelo menos, o sacerdote faça o batismo e abra seus olhos. Zaíra reflete sobre seus dois caminhos:

"ZAíRA - Estou só, meu Deus! Que será feito de mim?

Deus, comanda meu coração para não traí-lo.

Em efeito, serei eu muçulmana ou francesa? 
Filha de Lusignan, ou esposa de Orosmane?

Sou amante, ou cristã? Ó sementes que me fizeram!

Meu pai, meu país, serdes satisfeitos!(...)

À tua lei, Deus poderoso, sim, minha alma se entrega;

Mas fazeis com que meu amor desapareça de minha vista.

Caro amante! Esta manhã poderia eu prever

Que eu deveria hoje desistir de te ver? (...)

E te adoro, e te amar é um crime!"32

Orosmane vem chamar Zaíra para as bodas. A jovem não sabe como resistir, o que o sultão interpreta, de início, como virtude modesta. Mas Zaíra lhe fala dos cristãos e da morte de Lusignan. Orosmane não entende qual a relação entre os fatos, já que ela crescera sob os costumes muçulmanos e o morto era apenas um idoso desconhecido. Zaíra não quer magoar o amado, mas seu dilaceramento a impede de prosseguir, e ela se retira:

"ZAíRA - É custoso para mim, senhor, desagradar-vos;

Perdoai minha dor... Não, eu esqueço ao mesmo tempo,

E tudo o que sou, e tudo o que eu devo,

Eu não posso defender este aspecto que me mata.

Eu não posso... Ah! Tolereis que longe de vossa vista,

Senhor, eu vá esconder minhas lágrimas, meus problemas,

Meus votos, meu desespero, e o horror no qual me encontro.

(Ela sai). ${ }^{33}$

Orosmane não entende a brusca mudança de Zaíra. Corasmin acredita no amor da jovem, mas o sultão suspeita que o motivo da indecisão seja o rapaz francês. Corasmin conta que viu Néréstan chorando e suspirando, mas que nada observara em Zaíra. Porém Orosmane já está transfigurado pelo ciúme, como se já tivesse certeza da traição. Pensa em matar o cristão na frente da amada, e em fazer todos os cativos sofrerem. Com tais ameaças, o ato termina.

\footnotetext{
32 VOLTAIRE. Oeuvres Choisies. Paris, Chez P. Dupont, 1826, p. 490 (tradução própria).

${ }^{33}$ Id. Ibid., p. 493.
} 
Conversando com Zaíra, Fatime tenta convencê-la de que é Deus quem a está inspirando a desistir do casamento; mas a amiga está dividida. Desgostosa, chega a pedir a Deus para morrer, já que não poderá ficar ao lado de seu amado. Ao falar da impossibilidade do amor entre ela e o sultão, Zaíra exalta as suas virtudes:

"ZAíRA - Ah! Por que meu amante não nasceu para esse Deus?

Orosmane foi feito para ser sua vítima?

Poderia Deus odiar um coração tão magnânimo?

Generoso, benfeitor, justo, pleno de virtudes;

Se tivesse nascido cristão, o que seria a mais?"34

O trecho nos remete, de certa forma, a outra obra de Shakespeare, Romeu e Julieta. Na cena do balcão (II, ii), Julieta fala da perfeição de Romeu e da impossibilidade do amor entre ambos, aqui não por uma diferença religiosa mas pela disputa entre suas famílias:

"JULIETA - Romeu, Romeu, por que há de ser Romeu?

Negue o seu pai, recuse-se esse nome;

Ou se não quer, jure só que me ama

E eu não serei mais dos Capuletos.

ROMEU (à parte) - Devo ouvir mais, ou falarei com ela?

JULIETA - É só seu nome que é meu inimigo:

Mas você não é você, não é Montéquio!

Que é Montéquio? Não é pé, nem mão,

Nem braço, nem feição, nem parte alguma

De homem algum. Oh, chame-se outra coisa!

Que é que há num nome? O que chamamos rosa

Teria o mesmo cheiro com outro nome;

E assim Romeu, chamado de outra coisa,

Continuaria sempre a ser perfeito,

Com outro nome. Mude-o, Romeu,

E em troca dele, que não é você,

Fique comigo." 35

\footnotetext{
${ }^{34}$ Id. Ibid., p. 497.
} 
Fatime aconselha Zaíra a não revelar a Orosmane o que ela descobriu sobre si mesma, pois seu irmão pode ficar em perigo, bem como todo o povo cristão. A amiga discorda, mas Fatime a lembra que o sultão é o protetor da lei muçulmana, e que por amá-la demais não pode suportar muito sofrimento. Assim, convence Zaíra a ir se encontrar com o sacerdote em segredo. A conversa é interrompida pela entrada de Orosmane que, ainda transtornado, vem avisar que, por causa da estranha recusa da jovem, está agora desistindo do casamento. Sua cólera, porém, encontra as lágrimas de Zaíra, que insiste que o ama. O sultão se acalma, mas quer uma explicação para tudo. Zaíra lhe diz que não pode revelar seu problema agora, só no dia seguinte; reafirma seu sentimento e pede a Orosmane para ficar sozinha durante a noite. Mesmo machucado, ele concorda.

Orosmane comenta o ocorrido com Corasmin, mas continua com suas suspeitas, reclamando dos "caprichos" da amada. Méledor, um criado, entra trazendo uma carta do cristão para Zaíra. O sultão a abre, e crê haver encontrado a prova da traição da jovem:

\footnotetext{
"OROSMANE - Ah! Leiamos: minha mão treme, e minha alma surpresa

Prevê que este bilhete contém meu destino.

Leiamos... "Cara Zaíra, é tempo de nos vermos:

Há ao lado da mesquita uma passagem secreta,

Onde podereis sem ruído, e sem serdes percebida,

Enganar vossos guardas, e cumprir nossa esperança:

É preciso tudo arriscar, conheceis meu zelo:

Eu vos espero; morro, se não fores fiel." ${ }^{36}$
}

Transfigurado de raiva, ele manda chamar Zaíra, mesmo que Corasmin tente impedi-lo, e a questiona sobre um outro amor. Zaíra se ressente, mas continua afirmando que o ama. O sultão a chama de perjura, e diz ter em mãos algo que comprova que ela mente. Ela fica indignada com as dúvidas dele, o que o

\footnotetext{
${ }^{35}$ SHAKESPEARE, William. Romeu e Julieta; tradução de Bárbara Heliodora, edição bilíngüe. Rio de Janeiro, Nova Fronteira, 1997, $5^{\text {a }}$ reimpressão, pp. 73-75.

${ }^{36}$ VOLTAIRE, Op. cit., pp. 504-505.
} 
confunde. Quando ela se retira, Orosmane fica a refletir sobre a suposta falsidade da jovem. Mesmo concluindo por sua culpa, ainda quer tê-la, e planeja matar Néréstan para livrar Zaíra desse amor.

No último ato, Orosmane, junto a Corasmin, pede a um escravo que leve a carta a Zaíra e observe sua reação. Ao receber a missiva, a moça explica o conteúdo a Fatime: o irmão a chama para um encontro. Ela hesita, acha que colocará a si e aos cristãos em perigo, mas a amiga tenta convencê-la de que é Deus quem a está chamando. Critica o amor do sultão, e lembra a Zaíra que ele a ofendeu. A jovem o justifica, mas não consegue colocar de lado seus pressentimentos. Fatime chama o escravo e Zaíra lhe pede que diga a Néréstan para vir a seu encontro.

Ao saber disso, Orosmane fica furioso, e promete vingança. Corasmin fica à espera de Néréstan, e o sultão se esconde, à espreita. Ao ouvir a chegada de Zaíra, saca seu punhal com ódio. A jovem entra, achando que quem a espera na escuridão é o irmão, mas Orosmane se identifica e a apunhala.

Néréstan, Corasmin, Fatime e outros escravos surgem. O sultão proclama seu feito ao jovem cristão, o que o desespera:

\footnotetext{
"OROSMANE - (...) Teus olhos procuram por toda parte e ainda demandam

A pérfida que te ama, e que me desonra.

Vede, ela está aqui.

NÉRÉSTAN - Que dizes? Que engano!...

OROSMANE - Vede, eu te digo.

NÉRÉSTAN - Ah! Que vejo? Ah, minha irmã!

Zaíra!... Está morta! Ah, monstro! Ah, dia horrível!

OROSMANE - Sua irmã! Que acabo de ouvir? Deus, será possível?

NÉRÉSTAN - Bárbaro, é verdade (...)"37
}

\footnotetext{
${ }^{37}$ Id. Ibid., pp. 520-521.
} 
Orosmane, tarde demais, descobre seu engano. Néréstan revela que ele e Zaíra eram filhos de Lusignan, cuja última vontade fora ver a filha cristã. Mas eis que Deus a punira por haver amado um mouro. Fatime acusa Orosmane e proclama o amor que Zaíra tinha por ele, de uma forma similar à de Emília no último ato de Otelo. O sultão, inconformado, ordena a Corasmin que liberte todos os cristãos e endereça a Néréstan sua fala final, antes de morrer:

"OROSMANE - (...) Guerreiro desafortunado, mas menos ainda do que eu Deixai estas paragens sangrentas, leve à sua pátria

Este objeto que minha ira privou de vida.

Teu rei, todos os cristãos, conhecendo tuas penas, Jamais delas falarão sem verter lágrimas.

Mas se a verdade por ti se fizer conhecer, Ao detestar meu crime, talvez também me lamentem. Leva aos teus este punhal, que meu braço desgovernado Cravou em um seio que deveria me ser sagrado; Dize a eles que eu dei a morte mais tenebrosa À mulher mais digna, à mais virtuosa, De quem os atrativos inocentes o céu havia formado; Dize a eles que a seus pés eu havia posto meus reinos;

Dize a eles que em seu sangue minha mão mergulhou,

Dize que eu a adorava, e que eu a vinguei.

(Ele se mata)."

Podemos colocar lado a lado a fala acima e o adeus de Otelo, na peça shakespeariana ( $\mathrm{V}, \mathrm{ii})$ :

"OTELO - Uma palavra ou duas, por favor:

Fiz serviços ao Estado; eles o sabem -

Não importa. O que peço é que nas cartas

Em que contarem estes tristes fatos,

Falem de mim qual sou; não dêem desculpas,

E nem usem malícia. Falem só

De alguém que, não sabendo amar, amou

Demais. De alguém que nunca teve fáceis 
Os ciúmes; porém que - provocado -

Inquietou-se ao extremo; cujos dedos,

Como os do vil hindu, jogaram fora

Uma pérola rara mais preciosa

Que toda a sua tribo; alguém que alheio

Ao hábito das lágrimas, verteu-as

Em abundância, como verte a goma

A seiva de uma árvore da Arábia.

E digam que em Alepo, certo dia,

Quando um maligno turco de turbante

Agrediu um varão veneziano

E insultou rudemente a sua terra,

Peguei a goela ao cão circuncidado

E o golpeei assim! (Apunhala-se.)"39

As semelhanças são evidentes: o arrependimento, a preocupação com o que será dito de si - uma das questões centrais no Othello de Shakespeare é a reputação -, o pedido para que se diga a versão do protagonista que acaba de assassinar a esposa, a palavra final que leva à ação do suicídio. Os pontos de contato, na verdade, entre Zaíra e Othello, vão desde o tema, o fio que conduz a ação (a suspeita de traição da amada), até detalhes do enredo. Por exemplo, em ambas as peças o protagonista, que deveria se envolver em um combate, livra-se dele por conta da ausência do inimigo. Em Shakespeare, a frota turca naufraga; aqui, os franceses decidem atacar o Egito. Outra semelhança é a posição do herói trágico, um líder militar de origem moura que pouco entende do amor.

Contudo, Voltaire não admite o parentesco. Ao contrário, na dedicatória da peça, sem citar Shakespeare, critica a selvageria do teatro inglês e indica sua própria obra como modelo. Ao falar da composição de Zaïre em si, em uma carta, ele afirma:

\footnotetext{
${ }^{38}$ Id. Ibid., p. 523.

${ }^{39}$ SHAKESPEARE, William. Otelo, o Mouro de Veneza; tradução de Bárbara Heliodora. Rio de Janeiro, Lacerda, 1999, pp. 193-194.
} 
"Zaïre é a primeira peça de teatro em que eu ousei me abandonar à toda a sensibilidade de meu coração; (...) eu procurei um meio de exprimir esta paixão com toda a conveniência possível; e para enobrecê-la, eu quis colocá-la ao lado daquilo que os homens têm de mais respeitável. Tive a idéia de fazer contrastar, em uma mesma cena, de um lado a honra, o nascimento, a pátria, a religião; e de outro, o amor mais delicado e mais infeliz; os hábitos dos muçulmanos e os dos cristãos; a corte de um sultão e a do rei da França; e de trazer à cena trágica, pela primeira vez, os franceses. Da história real me servi apenas da época da guerra de são Luís; todo o resto é inteiramente invenção. A idéia dessa peça sendo tão nova e fértil, se arranjou dela mesma; e enquanto o plano de Éryphille me havia custado muito, o de Zaïre se fez em um único dia; e a imaginação excitada por tal plano chegou à peça em vinte e dois dias." ${ }^{40}$

Mesmo assim, a maioria dos críticos percebe as semelhanças como algo evidente. Um dos primeiros grandes críticos de Shakespeare na Alemanha, Gotthold Ephraim Lessing (1729-1781) já aponta o parentesco, exaltando as qualidades superiores, a seu ver, da obra inglesa:

"Seu Orosmane ciumento não fica aos pés do ciúme do Othello de Shakespeare. E entretanto Othello inquestionavelmente forneceu o estofo de Orosmane (...) Em Orosmane ouvimos um homem ciumento falar e o vemos cometer um ato violento de ciúme, mas do ciúme em si não ficamos sabendo nem mais nem menos do que sabíamos antes. Othello, ao contrário, é um manual completo dessa loucura deplorável; ali podemos aprender tudo o que se refere a ela, tudo o que a desperta e como podemos evitá-la.

"Mas é sempre Shakespeare, sempre e eternamente Shakespeare que entendeu tudo melhor do que os franceses, ouço meus leitores perguntarem". 41

Menos contundente, Robert de Smet considera a estréia de Zaïre em Paris no dia 13 de agosto de 1732 o primeiro contato do público francês com a tragédia

$\overline{{ }^{40} \text { VOLTAIRE, Op. Cit., pp. } 444-445 .}$ 
de Otelo, quatorze anos antes da tradução de Pierre Antoine de La Place (a tradução seguinte, de Le Tourneur, viria apenas em 1776). Nas palavras de Smet:

\begin{abstract}
"Zaïre, é lógico, não é uma tradução, e nem mesmo o que nós chamaríamos hoje de adaptação de Othello, ainda que pudéssemos denominá-la 'imitação'. O público de 1732 ignorava completamente a fonte da peça. Voltaire, em seu prefácio, não dá nenhuma pista sobre o fato de ele ter assistido a Othello encenado durante sua estadia em Londres, mas ele parece ter ficado impressionado e lembrou-se de pelo menos alguns de seus pontos principais. Zaïre tem basicamente o mesmo assunto que Othello, mas o tratamento dado ao tema é o que poderia ser esperado de um autor francês imbuído com preceitos clássicos e para quem a variação de espaço e tempo era pecado mortal. ${ }^{42}$
\end{abstract}

Julleville também considera a relação entre as peças clara, e tenta equilibrar as qualidades e os defeitos da obra:

\begin{abstract}
"O melhor empréstimo feito por Voltaire do teatro inglês foi a imitação que ele tentou, em Zaïre (1732), do amor ciumento de Otelo, o Mouro de Veneza. Zaïre é certamente a obra-prima de Voltaire no teatro; não que seja uma peça perfeita; mas ela tem o primeiro de todos os méritos: ela agrada, ela toca, ela interessa; após cinqüenta anos, ainda era levada com sucesso no teatro, e o destino da infeliz heroína ainda faz correr as lágrimas. Que mais pode-se querer? É certo que as personagens, todas romanescas, carecem de verdade; mas o que importa isso, se Lusignan tem realmente majestade, Orosmane tem paixão, se Zaíra é profundamente tocante? É verdade que o enredo é mal conduzido, que a peça é inverossímil, e repousa toda sobre um mal entendido que uma palavra poderia esclarecer.. ${ }^{43}$
\end{abstract}

João Caetano encenou a peça em 1839, com tradução de J. M. da Costa Silva (o texto não era inédito no Brasil). Faz parte do período que Décio de Almeida

\footnotetext{
${ }^{41}$ LESSING, G. E. "Letter 15 - Hamburg Dramaturgy”, in LEWINTER, Oswald. Shakespeare in Europe. Cleveland, The World Publishing Company, 1963, pp. 50-51.

${ }^{42}$ SMET, Robert de. Op. Cit., p. 98.
} 
Prado chama de "escalada neoclássica" do ator, entre 1837 e 1840 (apenas o Hamlet duciano é de 1843). Como afirma o crítico:

"Do Otelo João Caetano passa a Zaíra, progressão natural na medida em que ambas as peças, a primeira certamente e a segunda provavelmente, derivam do mesmo molde shakespeariano. (...) Não há dúvida quanto ao enobrecimento de Zaíra em relação a Otelo: nem vilão há na tragédia de Voltaire, apenas equívocos fatais. Se tudo é diverso - personagens, situações, sentimentos, época - os traços essenciais do enredo são os mesmos nas duas peças: o amor entre o mouro e a cristã, o caminhar sinuoso do ciúme, as falsas provas, a mulher inocente assassinada, a revelação tardia da verdade e o suicídio final do herói. Orosman, não menos do que Otelo, não obstante as suas virtudes afetivas e morais, esconde sob a capa de civilização um resto de barbárie. (...) Há, nos dois, qualquer coisa de felino, de agrestemente africano, que atraía e repelia as civilizadas platéias da Europa, fazendo passar-Ihes pela espinha um arrepio de admiração e horror. Nesse sentido, parecem ter engendrado um pequeno ciclo de peças sobre o ciúme, com fundo exótico, preferencialmente árabe, de que Zulmira e Ackmet e Rakima, de Antonio Xavier, seriam subprodutos. João Caetano, tendo começado pelas imitações, remontou, com o tempo, aos protótipos." ${ }^{44}$

Nas Lições Dramáticas, João Caetano não faz nenhuma referência direta à sua representação de Orosmane, que era entretanto um papel conhecido e estudado pelos críticos brasileiros. Já em 1833, Francisco Bernardino Ribeiro, Justiniano José da Rocha e Antonio Augusto de Queiroga, no texto "Ensaios sobre a tragédia", citam freqüentemente a obra de Voltaire como um exemplo contra a nova escola romântica:

"Mostrai-me produções do novo gênero que contrabalancem, que escureçam esses primores da escola clássica, que rebentam por todas as partes! Shakespeare? Mas o que esse inglês tem de sublime é clássico; o que nele se vê de romântico é somente suas incoerências, suas cenas inverossímeis ou ridículas. Schiller? Ainda não vale Crébillon. Goethe?... E

\footnotetext{
${ }^{43}$ JULLEVILLE, Petit de. Le Théâtre en France. Paris, Librairie Armand Colin, 1927.

${ }^{44}$ PRADO, Décio de Almeida. Op. Cit., pp. 28-29.
} 
toda a vossa escola romântica refundida para fazer um só homem produzirá uma Zaíra, um Maomé? Não vos creio. O vosso frenesi não desculpa os erros grosseiros em que caís. Mas deixemos de refutar o que está por si destruído." ${ }^{45}$

Apesar da opinião dos autores provar-se vencida rapidamente, devemos notar que a defesa da tragédia neoclássica acabou encontrando respaldo mesmo no repertório de um ator com um estilo de interpretação tão romântico como João Caetano. Se em números 0 ator encenou comparativamente poucas tragédias - apenas oito - em relação às peças românticas, todos os seus papéis trágicos não só tiveram ampla aceitação do público como permaneceram como momentos de glória em sua carreira. Não que outros triunfos não viessem com as obras românticas; e, dentre essas, uma peça que se destaca é justamente Kean.

\subsubsection{2- ALEXANDRE DUMAS E KEAN}

"to see him (Kean) act, is like reading Shakespeare by flashes of lightening" Coleridge

Edmund Kean (1787-1833) foi um dos grandes nomes do teatro inglês de sua época, tanto por seu talento quanto por sua vida tempestuosa fora dos palcos, incluindo uma condenação por adultério, bebedeiras, dívidas e um divórcio. É considerado o pioneiro entre os grandes atores a ter um estilo predominantemente romântico, e seu Otelo sempre foi considerado impactante. Seu primeiro grande sucesso ocorreu já em sua estréia no papel de Shylock, de O Mercador de Veneza, no teatro Drury Lane, em 1814. Apesar de ocasionalmente haver tentado a comédia, notabilizou-se por personagens ligadas à vilania e à paixão. Sua expressividade poderosa, aliada a um magnetismo pessoal intenso, moldou sua interpretação, visto que não se destacava nem por seus dotes vocais nem por uma aparência física

\footnotetext{
${ }^{45}$ Apud FARIA, João Roberto. Idéias Teatrais: o Século XIX no Brasil. São Paulo, Perspectiva/EDUSP,
} 
impressionante. Entre seus maiores sucessos, figuram Ricardo III, lago, Otelo, Macbeth e Barrabás, de O Judeu de Malta, de Christopher Marlowe.

O Otelo de Kean, estreado em cinco de maio de 1814, brilhou em um período que começou a ser marcado pelas regras rígidas do vitorianismo, que cortou grande parte das insinuações de cunho sexual ou ao menos dúbio das falas originais de Othello, a propósito de "refinar" o texto. É interessante perceber que os Otelos mais populares do período foram os daqueles artistas que, a despeito de atuarem nas versões mais mutiladas (ou "familiares") da peça, conseguiram demonstrar as paixões mais profundas e cruas, externando claramente sentimentos de ira, amor ou ciúme, os quais normalmente eram escondidos. Kean, apesar de não ter um físico grandioso, ganhava estatura pela paixão, expressa em maneirismos pessoais, transições abruptas, pausas inesperadas, enfim, todo um estilo de interpretação novo e, para muitos, mais "natural"46. Como afirma Rosemberg:

\begin{abstract}
"Os homens choravam em Otelo no século XIX - começando com Kean, o primeiro dos grandes Mouros cuja imagem física chegou até nós em detalhe. Kean não possuía o físico massivo e a dignidade que assegura a nobreza do herói em repouso; mesmo assim ele mantinha a estatura durante toda a peça pela profunda intensidade de sua paixão. O seu Otelo era a imagem do que Garrick havia sonhado e que Barry tinha parecido exprimir: uma expressão de violência, terror, amor, piedade. Ele era um grande instrumento emocional. As platéias tremiam com sua fúria; Byron chorava com seus soluços. Seu Mouro parecia ser a flor do romantismo no teatro, procurando por uma paixão além da conhecida.,"47
\end{abstract}

O autor comenta, porém, que o furor de Kean em cena era resultado não só da emoção, mas também de pensamento e estudo. Na verdade, Kean se notabilizou pela preparação incansável de seus papéis, assim como seus antecessores Garrick e Kemble - mas com resultados diferentes. Tanto o papel de Otelo quanto o de lago foram feitos por ele até o final de sua vida. Sua 
última apresentação, aliás, foi como lago, contracenando com seu filho Charles Kean representando o protagonista da tragédia.

A crítica da época traz um retrato muito vívido da visão de Kean em cena. De início, um crítico como Hazzlit acha Kean exagerado, mas posteriormente pede-lhe que não se torne mais moderado. Contudo, tenta equilibrar os méritos e os defeitos do ator no papel:

"Othello foi representado no Drury Lane ontem, com o papel principal sendo feito pelo Sr. Kean. Seu sucesso foi similar à dificuldade da empreitada. No geral, devemos observar que ele mostrou as mesmas excelências e os mesmos defeitos de suas personagens anteriores. Sua voz e figura não estão completamente de acordo com o papel, e nem houve o tempo todo aquela onda de paixão profunda e sustentada, impetuosa, mas majestosa, que (...) anima a nossa admiração e a piedade pelo mouro. Existiram, contudo, repetidas explosões de sentimento e energia que jamais vimos iguais. Toda a parte final do terceiro ato foi uma obra-prima de pathos profundo e uma composição maravilhosa, e seu efeito na platéia foi eletrizante. $O$ tom de voz com que ele disse o belo 'Então, oh, adeus!' calou no coração e na imaginação como as notas de alguma música divina." 48

Keats é outro que trata da voz de Kean e de seu estilo, de uma forma diferente, mas ainda mais contundente:

"Entre suas numerosas qualidades, aquela que nesse momento mais aparece para nós é a elegância, graça e musicalidade de sua elocução. Uma passagem melodiosa em poesia é cheia de prazeres tanto sensuais quanto espirituais. O espiritual é sentido quando as próprias letras impressas da linguagem caracterizada se mostram como os hieróglifos da beleza. (...) A vida sensual dos versos sai morna dos lábios de Kean, mesmo para alguém iniciado nos hieróglifos de Shakespeare, - iniciado na porção espiritual daquelas linhas às quais Kean adiciona uma beleza

${ }^{47}$ ROSENBERG, Marvin. The Masks of Othello. Berkeley; Los Angeles, University of California Press, 1971, p. 61.

${ }^{48}$ Apud BATE, Jonathan. The Romantics on Shakespeare. London, Penguin, 1992, p. 487. 
sensual. (...) Quando ele diz em Othello 'suspendam vossas espadas brilhantes, pois o orvalho as vai enferrujar', sentimos que sua garganta comandou onde as espadas ficariam (...) Outros atores estão continuamente pensando no efeito geral deles em uma peça; Kean se entrega à emoção instantânea, sem uma sombra de pensamento para mais nada." ${ }^{49}$

Mas Kean nunca foi uma unanimidade, como demonstra o comentário incisivo de Coleridge:

\begin{abstract}
"Kean é original; mas ele copia de si mesmo. Suas rápidas descidas do hiper-trágico ao infra-coloquial, apesar de às vezes produzirem grande efeito, são muitas vezes incompreensíveis. Vê-lo atuar é como ler Shakespeare por clarões de trovão. Eu não o considero cavalheiro o suficiente para interpretar Otelo." ${ }^{50}$
\end{abstract}

De qualquer modo, a popularidade de Kean não conheceu fronteiras, e platéias ficavam abarrotadas para vê-lo, não apenas na Inglaterra, mas também na França. Sua composição de lago foi tão bem sucedida quanto a de Otelo, e ele passou a alternar os papéis a cada noite de representação por várias temporadas.

Em 1827, companhias inglesas estiveram em Paris representando Shakespeare (não pela primeira vez, contudo; há registros de 1822, porém sem a mesma repercussão positiva). Dumas assistiu a essas apresentações, que o marcaram profundamente. Nas palavras de Maurois:

"O sucesso dos atores ingleses foi enorme. A violência da pantomima deles surpreendeu, depois entusiasmou. As cenas de agonia, nas quais Kean se contorcia, deixaram estupefato um público acostumado às mortes decentes do teatro francês. (...) Dumas (...) assistiu a todas as representações e tomou notas:

\footnotetext{
${ }^{49}$ Id. Ibid., p. 201.

${ }^{50}$ Id. Ibid., p. 160.
} 
"Eu vi Otelo interpretado por Talma, por Kean, por Kemble, por Macready, e por Joanny... Com Talma, ele era um mouro recoberto por uma camada de civilização veneziana; com Kean, ele era uma besta feroz, metade tigre, metade homem; com Kemble, ele era um homem mais maduro, irritadiço e violento; com Macready, ele era um Árabe do tempo dos Abencérages, elegante e cavalheiresco; com Joanny... ele era Joanny". [Alexandre Dumas, Souvenirs Dramatiques, tome II, p. 93.]

"Dumas aplaudiu loucamente Macready e Kean, Kemble e a bela Harriet Smithson. As cenas de loucura, de assassinato, de suicídio, o ciúme de Otelo, a morte de Desdêmona, a perturbação (...) Ele não conhecia o inglês, mas o movimento, a ação, o tom lhe foram suficientes." ${ }^{1}$

O próprio Dumas fala da impressão que os ingleses lhe causaram, e de sua admiração pela obra shakespeariana. Devemos nos lembrar que seu primeiro contato com Shakespeare se dera através de Ducis, uma representação de Hamlet feita por alunos do Conservatório entre 1819 e 1820 que impressionara o jovem Dumas a ponto de ele ter decorado o texto todo em apenas três dias anos antes de ele ter contato com o original shakespeariano, representado pelos ingleses:

"Já falei do imenso serviço que os atores ingleses me prestaram: Macready, Kean, Young, vieram a seu tempo completar a obra começada por Kemble e Miss Smithson. (...) Eu havia visto Hamlet, Romeu, Shylock, Otelo, Ricardo III, Macbeth, eu havia lido, eu havia devorado, não somente o repertório de Shakespeare como todo o repertório estrangeiro; eu havia reconhecido que, no mundo teatral, tudo emana de Shakespeare, como, no mundo real, tudo emana do sol; que ninguém podia ser a ele comparado: pois tendo vindo antes de todos os outros, ele havia permanecido tão trágico quanto Corneille, tão cômico quanto Molière, tão original quanto Calderón, tão pensador quanto Goethe, tão apaixonado quanto Schiller. Eu reconheci que suas obras continham tantos tipos quanto todas as outras reunidas; eu reconheci enfim que ele era o homem que mais havia criado, depois de Deus. 
"Eu já falei, desde o dia em que vi, na pessoa dos artistas ingleses. Os homens de teatro se esquecendo de que estavam em um teatro; esta vida fictícia entrando na vida positiva, à força da arte; esta realidade de palavras e de gestos fazendo dos atores as criaturas de Deus, com suas virtudes e vícios, com suas paixões e fraquezas; desde esse dia, minha vocação havia sido decidida." ${ }^{52}$

Frédérick Lemaître, o grande ator francês, mostrou a Dumas em 1836 uma primeira versão de enredo, escrita por Théaulon e Courcy, de uma peça sobre Kean, que falecera três anos antes, em grande parte devido a seus excessos. Lemaître ia estrear no Théâtre des Varietés, e para tal queria fazer o papel do astro inglês, com o qual compartilhava muitas características, como a intemperança e a impulsividade, e pediu ao dramaturgo para melhorar a peça. Dumas fez mais. Na palavras de Gautier,

"Nunca um papel mais feliz foi traçado para Frédérick Lemaître. (...) Duvidamos que Kean em pessoa pudesse interpretar melhor seu próprio papel." 53

Dumas reescreveu completamente a peça, enriqueceu a intriga, refez os diálogos, e inseriu na peça uma feroz sátira aos críticos. A obra se tornou um dos grandes sucessos das carreiras de Lemaître e de Dumas. Na verdade, como indica Maurois:

"[Dumas] havia colocado na peça muito de Frédérick - e de si mesmo. A cena na qual Kean injuria um par da Inglaterra provinha de uma discussão, ouvida por Dumas, entre Harel e Frédérick. O comentário feroz sobre a crítica inglesa, no $2^{\circ}$ ato, era uma investida de Dumas contra os críticos franceses." 54

\footnotetext{
${ }^{51}$ MAUROIS, André. Les Trois Dumas. Paris, Hachette, 1957, pp. 59-60.

${ }^{52}$ DUMAS, Alexandre. La Vie d'Alexandre Dumas Racontée par Alexandre Dumas. Textes récueillis par Alain Guérin. Paris, Julliard, 1953, p. 136.

${ }^{53}$ GAUTIER, Théophile. Histoire de l'Art Dramatique en France depuis vingt-cinc Ans. Paris, Hetzel, 1858-1859, vol. II, pp. 249-250.

${ }^{54}$ MAUROIS, A. Op. Cit., p. 154.
} 
Comentando a peça e as semelhanças entre Kean e Lemaître, Baldick afirma que o intuito geral do entrecho não era tanto satirizar os críticos, apesar de haver sido uma excelente oportunidade, mas

"[a intenção de Dumas foi mais] de dar a Frédérick os meios de mostrar todos os aspectos múltiplos de seu gênio (...) ele levou o papel à perfeição. (...) Um grande número de críticos afirmou que Frédérick oferecia uma semelhança estranha com o verdadeiro Edmond Kean, apesar da diferença física. (...) A semelhança entre ambos não era apenas por sua arte, mas se estendia à vida privada dos dois: ambos eram conhecidos por seus grandes débitos e pelo hábito da bebida; como Kean, Frédérick começou a beber após uma série de frustrações, e o hábito degenerou em vício. ${ }^{55}$

A peça de Dumas, Kean ou Desordem e Gênio, assim, foi representada pela primeira vez no Théâtre dês Varietés, em Paris, no dia 31 de agosto de 1836, com Frédérick Lemaître no papel-título sendo aclamado pela crítica.

O primeiro ato se passa no salão da casa do Conde de Koefeld. Eléna, a Condessa, esposa do embaixador da Dinamarca, dá ordem aos criados para a recepção de convidados que virão para jantar. Chega Amy, Condessa de Goswill, que pergunta o que Eléna tem feito. Esta conta que na noite anterior fora ao teatro Drury Lane e vira Edmond Kean como Hamlet. Faz vários elogios, e Amy acha o entusiasmo da amiga demasiado, e adverte a condessa sobre boatos de que Eléna estaria apaixonada pelo ator, o que seria muito pouco recomendável - em primeiro lugar, pela profissão de Kean, e também por sua má reputação. Eléna pergunta se a amiga acreditara nos boatos e se vale da negativa da outra para mudar de assunto.

O Conde, marido de Eléna, surge e fala sobre Lorde Mewill, nobre falido que deve se casar no mesmo dia com uma rica herdeira, Anna Damby, outra assídua freqüentadora do Drury Lane. Amy diz ao casal que adoraria um lugar no camarote deles para poder ver Kean de perto. O Conde lhe responde que 
ela poderá vê-lo mais de perto ainda, já que convidou o ator para a recepção da noite. As duas mulheres mostram-se surpresas, mas o Conde não vê problemas em ter Kean em casa, já que o próprio Príncipe de Gales o convida para várias festas. Além do mais, o ator virá para representar Falstaff após o jantar. Contudo, o nobre recebe uma carta de Kean trazida por um criado, na qual o astro recusa o convite, deixando Eléna visivelmente aliviada:

"O CONDE, lendo - «Meu senhor, estou desesperado por não poder aceitar vosso gracioso convite, mas um assunto sobre o qual não posso comentar me priva de estar entre os convivas de Vossa Excelência. Tereis a bondade, meu senhor, de depositar minhas desculpas mais vivas e minhas homenagens mais respeitosas aos pés da senhora condessa. 》 ELÉNA, à parte - Ah ! Eu respiro...

O CONDE - Vivemos em um século singular, é preciso convir : um ator recusa o convite de um ministro!" ${ }^{56}$

O criado anuncia a chegada do Príncipe, que traz notícias sobre o casamento de Lorde Mewill. A noiva havia desaparecido na hora da cerimônia. Segundo ele, o boato é que ela fugira com Kean. Enquanto Eléna se desespera, o Conde comenta que entende agora a carta recebida do ator. O Príncipe crê na veracidade do boato, e completa afirmando que Kean deve estar a caminho de Liverpool. Entretanto, no mesmo instante, o criado entra e diz que Kean está ali, espantando a todos.

Kean explica a aparente contradição dizendo não ser culpado da fuga de Miss Anna - ela realmente o procurara, mas ele não estava em casa. Traz uma carta da moça, e pede que Eléna a leia e desminta o boato, tudo pela reputação abalada de Miss Anna. Eléna concorda. Na carta, Anna demonstra que Kean não a conhece pessoalmente. A Condessa questiona o ator sobre a resposta dada e ele a instrui para ler do outro lado do papel. O que está ali, porém, é um recado de Kean para Eléna, tentando marcar um encontro às escondidas:

\footnotetext{
${ }^{55}$ BALDICK, Robert. La Vie de Frédérick Lemaître - le Lion du Boulevard. Paris, Éditions Denoël, 1961, pp. 182-183.
} 
"ELÉNA, lendo enquanto Kean volta a falar com o príncipe e o conde "Eu não sabia como fazer para vê-la, Eléna; não ousava vos escrever ; uma ocasião se apresentou e eu a aproveitei. Vós sabeis que os raros momentos que roubais para mim àqueles à nossa volta passam com tanta rapidez e tormento, que eles não marcam realmente a minha vida a não ser pela lembrança que deles tenho... » Ela pára, estupefata.

KEAN, que voltou para perto dela - Dignai-vos ler até o final, senhora.

ELÉNA, lendo - «Muitas vezes já procurei um meio pelo qual uma dama, de sua posição, e que me amasse verdadeiramente, pudesse me ceder por acaso uma hora sem se comprometer... e eis o que encontrei : se tal mulher me amasse o suficiente para me ceder uma hora, em troca da qual eu daria a minha vida... ela poderia, ao passar em frente ao teatro Drury Lane, fazer parar seu carro na bilheteria e entrar sob o pretexto de retirar um ingresso ; o homem que cuida da bilheteria me é dedicado, e eu lhe dei a ordem de abrir uma porta secreta, que eu mandei fazer em meu camarim sem que ninguém o saiba, a uma dama vestida de negro e com um véu, que talvez se dignasse a vir me ver... no dia de meu próximo espetáculo. » - Eis vossa carta, senhor." ${ }^{57}$

A Condessa diz aos outros que Kean é inocente, mas cala sobre o resto.

Alguns pontos chamam a atenção no primeiro ato, como as reviravoltas do enredo, principalmente no que se refere a fatos e boatos. O público descobre que, nessa peça, é difícil saber em quem acreditar, pois as pessoas muitas vezes fazem ou deixam transparecer o contrário do que afirmam (aqui, notadamente Kean e Eléna). Além disso, durante quase todo o primeiro ato, Dumas atiça a curiosidade dos espectadores com uma descrição minuciosa do protagonista antes da estrada do mesmo em cena. Todas as outras personagens apresentam fatos e opiniões que permitem a formação de uma imagem de como será Kean. Assim, quando ele irrompe no palco, muito já é sabido e pensado, e suas palavras e ações vão apenas completar um quadro já esboçado - como bom protagonista romântico, um ser complexo, com

\footnotetext{
56 DUMAS, Alexandre. Kean, adaptation de Jean-Paul Sartre, 16e édition. Paris, Gallimard, 1954, pp. 228-229 (tradução própria).

${ }^{57}$ Id. Ibid., pp. 233-234.
} 
qualidades e defeitos, encerrando em si tanto o grotesco quanto o sublime de que fala Victor Hugo.

Note-se o comentário, feito pelo conde, sobre a condição social do ator, que será desenvolvida mais profundamente durante o entrecho e que já chamara a atenção de teóricos franceses desde o século XVIII, como Diderot, no seu Paradoxo sobre o Comediante.

O segundo ato se dá nos aposentos de Kean em um hotel, pela manhã. O salão está desarrumado, com garrafas semivazias espalhadas pelo ambiente. No meio de tudo, estão dormindo Kean e seus amigos atores, David, Tom e Bardolph. Salomon e Pistol, à porta, observam e comentam a cena. Salomon conta que finalmente Kean passou uma noite sem ir à taverna, um fato raro, o que não o impediu de embebedar-se e participar de uma orgia. Começa a arrumar o salão e acorda os amigos de seu amo, um a um, inventando pretextos para eles irem embora. Lamenta que o grande Kean seja dado a esses prazeres. Ao tentar tirar uma garrafa das mãos do ator, este acorda. Admite que está errado em seu comportamento, mas defende que um ator deve conhecer as paixões:

"KEAN - (...) É preciso que um ator conheça todas as paixões para bem exprimi-las. Eu as estudo sobre mim mesmo, esse é o modo de sabê-las de cor." 58

Pistol, um pobre saltimbanco, vem pedir a Kean, antigo companheiro de apresentações, para ser padrinho de sua irmãzinha que acaba de nascer. Kean concorda e marca o batismo para a mesma noite, na taverna de Peter Patt.

Só, Kean fala com amor de seus colegas pobres do teatro, e relembra seus próprios tempos de miséria. Reflete sobre o que ganhou e o que perdeu ao melhorar de vida. Nesse momento, um criado anuncia a presença de Miss Anna Damby. Kean concorda em recebê-la, e sai para se arrumar. 
Kean quer saber o que pode fazer pela moça. Ela Ihe conta que é órfã, que está sendo forçada, por seu tutor, a desposar um homem que detesta, e que por isso fugiu e veio procurá-lo: quer se tornar atriz. Kean se compadece da inocência de Anna, e afirma que, como espectadora, ela só teve contato com o lado dourado da profissão, mas que há também um lado espinhoso. Ela está fascinada por ele. Ele, por sua vez, se encanta com a candura da moça, e acaba decidindo que o que parece uma inconveniência pode vir a ser um dever para ele: transformar uma dama em atriz. Diz que ela é bela, mas que isso não basta; é preciso também arte. Ela está disposta a estudar se ele a dirigir. Ele prevê o estudo de alguns anos, o que não será difícil já que ela é rica e pode se manter. Anna, contudo, Ihe conta que abriu mão de sua fortuna ao fugir da casa de seu tutor. Kean diz que ela tem que estudar ao menos seis meses antes de estrear, e ela afirma que trabalhará. Kean abre os olhos da jovem para todos os problemas que uma atriz pode ter. Anna pergunta como Kean conseguiu vencer. Ele admite que sofreu, mas no teatro quem sofre mais são as mulheres. Ela ainda vê as coisas boas da profissão: poder ser rei, ter o aplauso e a admiração das pessoas... Ele rebate com a realidade: ser rei de mentira, com coroa de papel; invejar outro tipo de trabalhadores. Contudo, ele admite que se uma nobre the oferecesse amor e fortuna para ele deixar o palco, ele se negaria. Jamais renunciaria ao palco, às suas emoções, não gostaria de ser rapidamente esquecido. Mas adverte a jovem: como ela ainda não se lançou a essa estrada, que creia nele e não entre para o teatro. Ela Ihe diz que um conselho dele é uma ordem. Conta que, ao fugir de casa, foi morar com uma tia que a acolheu e que a ama. Kean sugere que Anna fique com essa tia. A moça tem medo, pois Lorde Mewill é poderoso e descobrirá seu esconderijo. Ele diz que ela terá a lei a seu lado, e se dispõe a acompanhá-la até em casa. Salomon vem anunciar a chegada do Príncipe. $O$ ator pede que Salomon se desculpe e diga que não pode recebê-lo, pois está dormindo. Anna comenta que é a segunda vez que ele a salva.

$\mathrm{O}$ ato III inicia-se na taverna de Peter Patt. Algumas pessoas bebem, entre eles John Cooks, e um policial lê jornal. Lorde Mewill entra e fala com o dono da estalagem. Quer reservar o melhor quarto do lugar para, segundo ele, uma

${ }^{58}$ Id. Ibid., p. 239. 
jovem dama que virá mais tarde, e paga-Ihe adiantado. Pede para conhecer algum barqueiro, e Peter the apresenta George. O nobre quer alugar o barco por alguns dias, e negocia com 0 homem. Ambos saem para ver a embarcação. Kean chega, pede um champanhe e senta-se para esperar seus amigos para o batizado. Vê o olho roxo de John e o desafia a lutar quando este desdenha da bebida que ele escolheu. O policial não interfere, curioso. Os dois lutam, e o ator acerta o outro olho de John, que cai nos braços de seus amigos. Kean pede outra garrafa, e o policial (que parece não saber quem ele é) 0 cumprimenta. Diz que gosta de emoções fortes - lutas, brigas de galo - e que adora artistas. Kean promete que o fará conhecer um artista se o policial passar a noite com ele e seus colegas. Animado, o guarda sai para avisar à esposa que não o espere.

Ketty, artista outrora apaixonada por Kean, chega com a troupe de saltimbancos. Kean pede a Pistol notícias de Bob, e o amigo lhe conta que o velho se acidentou na rua, e terá que ficar de cama por seis semanas. Kean imediatamente decide escrever ao Diretor do teatro Covent Garden, para anunciar que no dia seguinte fará um espetáculo - ato II de Romeu e o papel de Falstaff - em benefício de um amigo. Ketty e Pistol se alegram, e todos saem para o batizado. Anna chega com uma dama de companhia e pede um quarto. Peter the diz que já recebera ordens para preparar seu melhor aposento para uma dama. Anna se surpreende, mas se apressa a subir.

Salomon aparece, precisando falar com Kean. Peter sai. Sozinho, Salomon pega o jornal e procura a crítica sobre o espetáculo da noite anterior: O Mouro de Veneza (este é o título pelo qual Othello era conhecida no período, apesar de, no original, esse ser apenas o subtítulo). Encontra o seguinte:

\footnotetext{
"SALOMON - (...) Ah! (Lendo) «Teatro Drury Lane, representação do Mouro de Veneza. Sr. Kean - o espetáculo de ontem atraiu pouca gente...» Quinhentas pessoas ficaram sem ingresso; a platéia estava abarrotada. «A má escolha da noite.» Obrigado! Levou-se O Mouro de Veneza e Sonho de uma Noite de Verão, as duas obras-primas de Shakespeare. «A mediocridade dos atores... » A elite da companhia
} 
simplesmente: Miss O’Neill, Mistress Siddons, Kean, o ilustre Kean! «a interpretação frenética de Kean, que faz de Otelo um selvagem.» Bem, o que é que ele quer que se faça? Um dândi? (olhando a assinatura do autor do artigo.) Ah ! Isso não me surpreende mais : “Cooksman.» É conhecido! Oh, vergonha, vergonha! Eis os homens que julgam, que condenam, e que por vezes estrangulam. (Ele pega um outro jornal.) Ah! Este aqui, é outra coisa ; o artigo é de um colega, Sr. Brixton ; ele criou o hábito de fazer as críticas ele mesmo, por medo que os outros não lhe façam justiça. público não sabe de nada; mas nós!... Vejamos. «A representação foi magnífica ontem no Drury Lane ; a sala estava apinhada ; e metade das pessoas que foram à bilheteria não puderam encontrar um lugar. A grande e sombria figura de lago...» É o papel dele! «foi magnificamente interpretada pelo Sr. Brixton. " Aí está um que não se esfola, ao menos. De resto, não há nada de mal em alguém só falar bem de si, cada um é livre. «A fraqueza do ator encarregado de representar Otelo.» Este aqui o acha muito fraco ; o outro o achava forte demais ! "serviu para ressaltar melhor ainda a atuação de nosso célebre... » (Ele atira longe o jornal.) Que panelinha! Panelinha! Ah! Meu Deus, sou feliz por não ser mais do que um pobre ponto." ${ }^{59}$

É um trecho particularmente rico em referências, desde as obras shakespearianas até o evento teatral em si. Mas o que mais chama a atenção aqui são os comentários em relação aos críticos teatrais, o que garantiu a Dumas e a Lemaître certa polêmica e mais popularidade ainda à peça.

Na seqüência, Kean entra e Salomon o informa de que há uma ordem de prisão contra ele, por uma dívida de quatrocentas libras. Kean resolve não voltar para seu hotel. Anna entra, e ele se surpreende com a presença dela em um lugar tão impróprio, mas ela diz que viera até ali seguindo instruções de uma carta dele. Kean estranha, pois não é a sua caligrafia na missiva, mas Anna o insta a ler todo o conteúdo:

"KEAN, lendo - « Senhorita, alguém a viu entrando em minha casa, e dela saindo ; alguém a seguiu: vosso esconderijo foi descoberto ; (...) Há

${ }^{59}$ Id. Ibid., p. 258. 
apenas um meio de escapar de vosso perseguidores : vinde esta noite ao porto, perguntai sobre a taverna do Buraco do Carvão. Um homem mascarado virá buscar a senhorita; segui-o confiante, ele vos conduzirá a um lugar onde estareis a salvo de toda procura, e onde me encontrareis. Nada temais, senhorita, e depositeis em mim toda a vossa confiança ; pois tenho por vós tanto respeito quanto vos tenho amor. EDMOND KEAN. Velo por mim assim como por vós ; eis porque não vou em pessoa suplicar-vos que tome esta resolução, a única que pode vos salvar." 60

Kean comenta que foi muita sorte ele ter vindo até ali, e pede a Anna que lhe conte tudo, como a um irmão, pois ele vai defendê-la. Ele diz suspeitar que o ódio da jovem por Lorde Mewill provém de um amor que ela sente por outra pessoa. Anna confirma. Conta que, há algum tempo, tinha ficado doente; sem esperanças, um médico aconselhou seu tutor a levá-la para divertir-se no teatro. Ela narra sua primeira experiência no local, assistindo a Romeu, peça que a encantara. Kean quer saber que ator fazia o papel de Romeu. Anna não escuta e continua contando:

\begin{abstract}
"ANNA - (...) Dois dias depois, me levaram assistir ao Mouro de Veneza... Lá cheguei com todas as minhas lembranças de Romeu... Oh! Mas, dessa vez, não era mais a mesma voz, não era mais o mesmo amor, não era mais o mesmo homem; mas foi como sempre o mesmo encantamento... a mesma felicidade... o mesmo êxtase... Contudo, agora eu já podia falar, eu podia dizer : «É belo!... É grande!... É sublime!

KEAN - E quem interpretava Otelo?

ANNA - No dia seguinte, fui eu que perguntei se não iríamos ao Drury Lane. Era a primeira vez, após um ano talvez, que eu manifestava um desejo ; adivinhareis facilmente que ele foi atendido. (...) Romeu me havia feito conhecer o amor, Otelo o ciúme, Hamlet o desespero... Essa tripla iniciação completou o meu ser... Eu estava abatida, sem força, sem desejo, sem esperança ; meu peito estava oco, minha alma já me deixara, ou ali ainda não estava, quando a alma do ator passou pelo meu peito : eu compreendi que apenas nesse dia eu comecei a respirar, a sentir, a viver!"
\end{abstract}

\footnotetext{
${ }^{60}$ Id. Ibid., p. 260.

${ }^{61}$ Id. Ibid., p. 262.
} 
Kean está quase morrendo de curiosidade. Ela apenas diz que o nome do ator é justamente o nome daquele que ela não ousa dizer a ele. Emocionado, ele muda de assunto e volta a falar da carta que ela recebera. Diz crer que um mascarado virá procurá-la. Por isso, manda chamar o guarda que se tornara seu amigo e pede a ele que salve a jovem, só então contando ao rapaz que ele é Kean. Impressionado, o policial põe-se à disposição da moça. Kean fica à espera, sozinho, e reflete sobre os acontecimentos.

Lorde Mewill, mascarado, entra, e Kean the impede a passagem. Com ameaças, ordena que o outro tire a máscara, impedindo-o de sair. Arranca-lhe o disfarce, chamando a todos para que vejam quem está ali. Os dois homens se reconhecem, enquanto as pessoas aparecem. Kean exige que o nobre se explique, já que utilizara o seu nome para seu plano. O Lorde diz que um par da Inglaterra como ele não pode se bater com um saltimbanco, frase que dá o gancho para um longo monólogo de Kean sobre as diferenças entre o nobre e o artista, comparando a trajetória de ambos (a de Lorde Mewill cheia de baixezas, e a de Kean, um caminho de superação e honradez). Sugere um brinde à livre escolha de Miss Anna Damby, e acaba por enxotar o Lorde do local.

O quarto ato se dá no camarim de Kean. A cena começa com um quadro do cotidiano teatral: Salomon prepara um copo de água com açúcar e explica a Pistol que Kean deve fazer gargarejos nos entreatos. Falam sobre o rico guarda-roupa do ator, e Pistol, espiando, descobre a porta secreta. Ele comenta que a fila de público já está enorme, e se retira quando Kean entra, em crise com a sua arte e as suas dívidas. Salomon comenta com o patrão que ele precisa ter ordem, mas Kean acha que a ordem destruiria seu gênio. Salomon quer convencê-lo a usar parte da renda da noite para pagar a dívida de quatrocentas libras, porém o ator se nega a fazê-lo. Sozinho, Kean exalta as qualidades do amigo fiel que o assiste. De repente, alguém chega pela porta secreta: é Eléna. Kean mal pode acreditar. Ela dá a ele um retrato seu: 
"ELÉNA - (...) Eu quis que em minha ausência ao menos meu retrato respondesse por mim.

KEAN - Vosso retrato!... Haveis mandado fazer vosso retrato para mim, Eléna? (...) Eu o desejo... aqui... aqui... sobre meu coração... sempre!

ELÉNA - Me amais portanto?

KEAN - É possível que me pergunteis?

ELÉNA, tomando sua mão - Meu Otelo!

KEAN - Oh! Dizeis bem, pois eu sou ciumento como o Mouro de Veneza, estais ouvindo, Desdêmona!"

Ele demonstra ter ciúmes não do Conde, marido dela, mas da proximidade entre ela e o Príncipe de Gales. As juras de amor são interrompidas por batidas na porta do camarim: são justamente o Príncipe e o Conde. Eléna se desespera, mas Kean a instrui a sair pela porta secreta. Para ganhar tempo, pede ao Príncipe uma carta escrita de próprio punho; justifica isso e a porta trancada por ter homens à sua procura por causa das quatrocentas libras. Despede-se apaixonadamente da amada e recebe do Príncipe, pelo vão da porta, uma nota no valor de sua dívida. Kean se apressa a abrir, e os dois homens entram, com Salomon. O Príncipe suspeita que, do camarim do "Romeu", acaba de escapar uma "Julieta". O ator tenta mudar de assunto e vai se vestir, pois já soou o segundo sinal. Antes, dá a Salomon o dinheiro para que ele vá pagar os credores. O Conde inquire o Príncipe sobre a mulher que supostamente estava ali. Sugere que poderia ser Miss Anna, mas encontra o leque de sua esposa. Guarda-o consigo, sem contar ao Príncipe a quem pertence. O Príncipe diz a Kean que um "insolente" insultara Lorde Mewill na noite anterior. O Conde se retira para Kean terminar de se arrumar, mas o Príncipe fica no camarim a pedido do ator. Kean agradece e pede desculpas por não tê-lo atendido em seus aposentos no dia anterior; porém, não quer explicar a razão da recusa. O Príncipe se ressente, pois sempre dera provas de amizade a Kean - sua companhia, seu dinheiro... Contudo, Kean teme que, se Ihe pedir mais um favor, este Ihe seja negado. Explica que os amores dos artistas são estranhos e que na platéia, às vezes, há uma mulher que é o "anjo inspirador do nosso gênio (p. 277)", para a qual ele representa e se esquece

\footnotetext{
${ }^{62}$ Id. Ibid., pp. 272-273.
} 
dos outros espectadores. Acaba por pedir ao Príncipe que ele não corteje a Duquesa, pois tem ciúmes. O Príncipe acusa Kean de ser amante de Eléna, o que o ator nega: diz que é um amor artístico, do qual depende sua vida, sua glória, sua felicidade. Implora ao Príncipe que não vá ao camarote dela. Salomon vem chamar o ator, que lhe diz que só há amizade realmente entre iguais. Pela porta secreta, surge a criada de Eléna procurando, em vão, o leque da patroa, que fora um presente do Príncipe. Kean comenta o fato e questiona um contra-regra, Davies, que diz ter visto o objeto com o Conde de Koefeld. Kean não quer que a cortina suba antes que possa prevenir Eléna, mas 0 público está impaciente:

\footnotetext{
"KEAN - (...) Oh! Profissão maldita... na qual nenhuma sensação nos pertence, na qual nós não somos donos nem de nossa alegria, nem de nossa dor... na qual, o coração quebrado, é preciso ser Falstaff; na qual, o coração contente, é preciso ser Hamlet! Sempre uma máscara, jamais um rosto..."63
}

Acaba por decidir que não vai atuar. Pistol se desespera juntamente com Salomon - seria a primeira vez que Kean faltaria com a sua palavra. Finalmente, $\mathrm{o}$ ator se convence e vai se colocar nos bastidores.

O último ato começa no teatro Drury Lane, como se a platéia assistisse à apresentação de Kean: temos a encenação do trecho em que Romeu e Julieta, após uma noite de amor, têm que se despedir (ato III, cena V) - não é o trecho, aliás, que Kean tinha anunciado que representaria. É interessante comparar a versão francesa usada por Dumas com o original shakespeariano: enquanto as imagens poéticas - fortemente calcadas, na peça toda, nos corpos celestes e na natureza - são mantidas ao máximo, adaptadas para a métrica e o esquema de rimas francês (de decassílabos em pentâmetro iâmbico para alexandrinos, e de versos no geral livres para rimas emparelhadas), o beijo pedido por Romeu é suprimido e há diferenças na fala da ama, que anuncia o pai de Julieta e não a mãe:

\footnotetext{
${ }^{63}$ Id. Ibid., p. 281.
} 
"JULIETA - Não voltes os olhos para o horizonte vermelho;

Podes ficar ainda, não é o sol que vem;

Era o rouxinol e não a cotovia

Cujo canto deixou teus ouvidos inquietos;

Escondido nas ramagens de uma romãzeira em flor

Toda a noite, ali, ele canta sua dor...

Podes ficar ainda, podes crer em tua Julieta.

ROMEU - Oh! É bem o sol, e é bem a cotovia!

Vede este risco luminoso, com inveja de minha felicidade,

Que fura o horizonte e se estende até nós;

Vede esta manhã sorridente, um pé já sobre a montanha,

Pronta para alçar vôo através dos campos;

Vede no céu menos obscuro as estrelas empalidecerem:

É preciso partir e viver, ou ficar e morrer...

JULIETA - Não, não é o dia: é algum meteoro

Que, para guiar teus passos, adiantou a aurora...

Enganas-te, amigo; fica.

ROMEU - Eu ficarei,

$E$, já que queres, como tu eu direi:

Não, não é o fogo da aurora oriental,

É a irmã de Apolo, é a rainha de fronte pálida;

Não é a cotovia na rama alegre

Cujo canto matinal se lança pelos céus.

Ah! Creia-me, eu tenho bem mais inclinação, eu te juro,

A ficar do que a partir; e se, vingando a injúria

Que minha presença traz à tua nobre casa,

A morte me vier de frente ou por traição,

A morte, de quem teme-se tanto a dor desconhecida,

Jogando-me a teus pés, ela será bem-vinda...

Oh! Não, bem tu falaste, não é o dia:

Fiquemos... Eu te amo! E tu, me amas, meu amor?

JULIETA - É o dia, é o dia! Oh! Eu estava fora de mim;

Fugi, Romeu! De medo estou toda gelada;

Não sei aonde vou, não sei onde estou,

$\mathrm{E}$ não tenho mais que uma palavra na boca... Fugi, fugi!

AMA - Madame...

JULIETA, entrando - Que queres? 
AMA - Vosso pai!

JULIETA - Meu pai!

Ouviste?

AMA - Vai vir!

ROMEU - Oh! Contra sua cólera,

Anjo, eu te remeto à guarda de Deus.

JULIETA - Adeus, meu Romeu..." ${ }^{64}$

Em Shakespeare (III, v), a mesma cena é apresentada assim:

"JULIETA - Mas já quer ir? Ainda não é dia.

Foi só o rouxinol, não cotovia

Que penetrou seu ouvido assustado.

Toda noite ele canta entre as romãs.

Verdade, amor; foi só o rouxinol.

ROMEU - Foi o arauto do dia, a cotovia,

E não o rouxinol. Veja os clarões

Que já rendaram as nuvens no leste.

Cada vela do céu já se apagou

E o dia, triunfante, se prepara

Para pisar nos cumes das montanhas.

Ou vou e vivo, ou fico aqui e morro.

JULIETA - Essa luz não é o dia, amor; eu sei.

É um meteoro que o sol exalou

Só para servir de tocha pra você,

E iluminar seu caminho para Mantua.

Fique um pouco; não é preciso ir.

ROMEU - Então, que eu fique, e seja executado;

Concordo, se é assim que você quer.

Esse cinza não é olhar da aurora,

Mas só o reflexo pálido da lua.

Não ouvi cotovia, cujo canto

Reboa até a cúpula do céu.

Que me importa partir. Quero ficar.

Conversemos, amor; não é a aurora.

${ }^{64}$ Id. Ibid., pp. 284-285. 
JULIETA - É sim, é sim; você tem de ir embora.

É a cotovia que canta assim, tão mal,

Com agudos estridentes, em discórdia.

Dizem que a cotovia faz, com graça,

A divisão dos ritmos de seu canto;

Mas, sem graça, ela agora nos divide.

Dizem que ela e o sapo trocam de olhos;

Só sinto que não troquem também voz,

Pois sempre me parece rude e armada,

E o expulsa daqui nesta caçada.

Vá embora; a luz cresce e mostra as cores.

ROMEU - Clara é a luz, escuras nossas dores.

Entra a ama, apressada.

AMA - Senhora.

JULIETA - O que é, ama?

AMA - A senhora sua mãe vem ao seu quarto.

Já é dia; é melhor 'star prevenida. (Sai)

JULIETA - Janela, que entre a luz e saia a vida!

ROMEU - Adeus; um beijo mais e eu desço. (Ele desce)." ${ }^{\text {"65 }}$

Quando Kean, como Romeu, vai sair pela balaustrada, percebe a presença do Príncipe de Gales no camarote de Eléna. Ao invés de se retirar, como o texto pede, ele fica em cena e fixa o olhar nos dois, com os braços cruzados. A atriz que faz o papel de Julieta tenta convencer o ator a sair, achando que ele esqueceu o texto, enquanto Salomon, dos bastidores, fica a chamá-lo. Mas Kean surpreende a todos:

\footnotetext{
"JULIETA - Romeu!

KEAN - Quem é que me chama Romeu? Quem é que acredita que eu faça aqui o papel de Romeu?

JULIETA - Kean, enlouqueceste?

KEAN - Eu não sou Romeu... Eu sou Falstaff, o companheiro de sacanagens do príncipe herdeiro da Inglaterra... A mim, meus bravos camaradas!... a mim, Poins!... a mim, Peto!... a mim, Bardolfo!... a mim,
}

\footnotetext{
${ }^{65}$ SHAKESPEARE, William. Romeu e Julieta; tradução de Bárbara Heliodora, edição bilíngüe. Rio de Janeiro, Nova Fronteira, 1997, $5^{\text {a }}$ reimpressão, pp. 149-151.
} 
Sra. Quickly a hospedeira!... e bebam, bebam muito, que eu bebo à saúde do príncipe de Gales, o mais sacana, o mais indiscreto, o mais vaidoso de todos nós! À saúde do príncipe de Gales, a quem tudo é bom, desde a rapariga da taverna que serve os marujos do porto, até a dama de honra que coloca o manto real sobre os ombros de sua mãe! Ao príncipe de Gales, que não pode deitar os olhos sobre uma mulher, virtuosa ou não, sem perdê-la com o seu olhar! Ao príncipe de Gales, de quem eu acreditei ser amigo, e de quem não sou mais do que o joguete e o bufão!... Ah! Príncipe Real, é sorte serdes inviolável e sagrado, eu vos juro !... pois, sem isso, haveria contas a acertar com Falstaff.

LORDE MEWILL, de um camarote - Abaixo Kean! Abaixo o ator!

KEAN - Falstaff?... Eh! Não sou Falstaff mais do que era Romeu ; sou o Polichinelo, o Falstaff das encruzilhadas... Um bastão para o Polichinelo, um bastão para Lorde Mewill, um bastão para o miserável raptor de donzelas, que carrega uma espada mas que se recusa a lutar contra aqueles de quem roubou o nome, e isso, sob o pretexto de que é nobre, de que é lorde, de que é um par da Inglaterra... Ah! Sim! Um bastão para Lorde Mewill... e nós riremos... Ah! Ah! Ah! Que eu sofro!... A mim! Meu Deus! A mim!

Ele cai nos braços de Julieta e de Salomon, que o retiram pela porta dos bastidores."

Nessa fala, Kean evoca particularmente as personagens da "Henriada" (obras relativas à formação e ao reinado de Henrique $V$ ) shakespeariana: as peças Henrique IV parte I, Henrique IV parte II e Henrique V (que formam, juntamente com Ricardo II, a primeira tetralogia histórica composta por Shakespeare). Nos dois Henrique IV, Falstaff e o então Príncipe de Gales, Hal, são companheiros inseparáveis de boemia, em uma relação que tem um componente de parental e filial, mas que também demonstra algumas rusgas (sem que Falstaff se dê conta, Hal vai ficando, ao longo das obras, cada vez mais ferino, antecipando o que fará ao tornar-se rei). Em torno deles, há um grupo de pessoas do povo Bardolfo, Nym, Poins, Peto, Mistress Quickly (alguns dos nomes tendo sido aproveitados por Dumas para nomear seus próprios personagens) - que compõem o núcleo cômico das peças, em contraponto à ação séria que gira

\footnotetext{
${ }^{66}$ DUMAS, Alexandre. Op. Cit., p. 286.
} 
em torno do rei Henrique IV, em suas tentativas de debelar rebeliões internas do reino e de expiar sua culpa pela morte do primo e antecessor, Ricardo II. Ao final de Henrique IV parte II, após ser coroado, Hal renega a amizade de Fasltaff, na famosa "cena da rejeição" (V, v). Em Henrique $V$, que narra as glórias militares do novo monarca, Falstaff não aparece; Mistress Quickly narra sua morte, causada provavelmente pela dor dessa rejeição, que lhe quebrara o coração. Sua trajetória termina melancolicamente. Falstaff sempre foi um dos papéis mais queridos e conhecidos de Shakespeare na Inglaterra, e Harold Bloom chega a colocá-lo ao lado de Hamlet como as duas maiores criações do dramaturgo, pela força de suas palavras e da inteligência afiada. ${ }^{67}$

Quando Kean desmaia, há uma confusão em cena e Salomon anuncia que a representação não pode continuar:

"SALOMON, se aproximando, um lenço em mãos - Cavalheiros, senhores, a representação não pode continuar... O sol da Inglaterra se eclipsou : o célebre, o ilustre, o sublime Kean acaba de ser vítima de um ataque de loucura." ${ }^{68}$

A cena seguinte se passa nos aposentos de Kean. Em um salão, Salomon, Bardolph, Tom, David, Darius e Pistol discutem o ocorrido. Salomon informa que Kean passou uma noite terrível, e que o médico está agora com ele. A loucura do ator o faz ter acessos frenéticos de raiva, que o levam a bater em quem estiver por perto. $O$ médico entra e prescreve o tratamento: parece que 0 caso é sério. Os colegas trocam sugestões. A campainha toca, é Kean que está chamando Salomon. Os outros saem rapidamente, com medo. Kean entra e pergunta a Salomon o que este dissera aos atores. Ele admite ter dito que Kean está louco, insultando o Príncipe e Lorde Mewill e depois desmaiando, e comenta que acha que Kean será punido pelo que dissera na noite anterior. Kean diz não se importar se será preso ou não, e quer ver a lista das pessoas que vieram visitá-lo: há nobres e ricos, mas também artistas, cocheiros, gente comum. Kean procura o nome de Eléna, mas nada encontra. Adverte Salomon

\footnotetext{
${ }^{67}$ Vide BLOOM, Harold. Shakespeare a Invenção do Humano. Rio de Janeiro, ed. Objetiva, 1998, em particular os capítulos sobre Henrique IV e As Alegres Comadres de Windsor, pp. 346-401.
} 
de que, se uma dama o procurar, que a deixe entrar (usa o codinome Ariel, mais uma referência a Shakespeare). Sozinho em cena, o ator fala de sua angústia quanto ao episódio do leque. Alguém bate à porta. Salomon vai abrir e volta anunciando que "ela" chegara.

Mas quem surge não é Eléna, mas Anna, que diz ter vindo por estar preocupada. Kean se emociona com a sua bondade, e a compara com a Condessa, que nem procurara saber o seu estado. Pede desculpas à jovem e Ihe conta que não está louco, ao que ela retruca que pode então partir aliviada: assinara um contrato com o correspondente do teatro de Nova York. Pergunta a Kean se pode escrever-lhe, pedindo conselhos. Ele promete que a aconselhará, e pergunta quando ela parte. Ela diz que seu navio sai em duas horas. Nesse momento, Salomon entra, com ar de mistério, e anuncia que uma dama chegou. É Eléna. Kean não sabe o que fazer com a presença de Anna. Esta diz que quer falar com a Condessa, para pedir-lhe que o faça feliz. Ele argumenta que Eléna não acreditará na inocência de ambos, estando juntos a sós nos aposentos dele, e suplica a Anna que se esconda em uma saleta ao lado. Ela sai. Eléna entra e diz que demorou a vir pois teve medo do perigo. Afirma que o boato corrente, que pode levar Kean à cadeia, é de que o acesso que ele tivera no teatro fora de ira, não de loucura, e assim os insultos que ele dirigira ao Príncipe e ao Lorde deverão ser punidos. Ela diz ter vindo para pedir a Kean que fuja da Inglaterra imediatamente. Ele desdenha das acusações, e eles debatem. Kean conta a Eléna que o Conde encontrara o leque dela no camarim, e pede-lhe que então fuja com ele. Ela recua e afirma que eles devem separar-se e esquecer um do outro. Pede-lhe também que ele devolva o retrato que ela the dera, e que seja razoável. Ele dificulta as coisas: quer o leque dela em troca. Ela diz que já se sacrificou por ele. Ele lembra que ela só sacrificara o próprio orgulho, e que ele acabara de sacrificar bem mais apenas por ciúmes dela. Decepcionado, ele devolve o retrato: parece curado de sua paixão:

"KEAN - Acabais de fazer uma cura maravilhosa. Eu tinha o transporte, o delírio, algo assim como uma febre cerebral ; vós me aplicais gelo sobre a

${ }^{68}$ DUMAS, Alexandre. Op. Cit., p. 287. 
cabeça e o coração, estou curado. Mas uma ausência mais longa provavelmente aumentaria as suspeitas do conde, se admitirmos que o leque vos fora ofertado por ele; depois, de uma hora para outra, o guarda pode vir me prender...

ELÉNA - Ah! Kean, eu prefiro vossa cólera do que vossa ironia. Deixareisme assim?"69

Ele sugere que ela saia, mas ouve-se repentinamente a voz do Conde na sala ao lado. Ele quase decide esconder a Condessa com Anna, mas decide colocá-la atrás das cortinas, já que as janelas dão para o Tâmisa e ninguém a verá. Feito isso, Kean ordena a Salomon que deixe o Conde entrar. Este anuncia que veio para duelar com o ator, sob qualquer pretexto. Kean diz não saber qual foi sua ofensa. Irritado, o Conde duvida da fama de corajoso que o outro tem, mas Kean continua se negando a enfrentar o marido de Eléna. Este ameaça punir a "cúmplice" do ator, que insiste em dizer que o Conde está enganado. Afirma que a Condessa é inocente. O Conde mostra então o leque e questiona Kean. Nesse momento, Salomon entra com uma nota urgente do Príncipe de Gales, na qual está a salvação do ator:

"O CONDE, lendo - «Meu caro Kean, queira mandar fazer uma busca com a maior urgência dentro de vosso camarim; creio ter ali esquecido ontem o leque da Condessa de Koefeld, que eu tinha tomado emprestado a fim de mandar fazer uma cópia para a Duquesa de Northumbeland. Hoje irei aí tirar a limpo a querela estúpida de ontem no teatro, por causa daquela moça da Ópera; jamais imaginaria que uma amizade como a nossa pudesse ser alterada por semelhantes bagatelas. Afetuosamente seu, George. 》

KEAN - Essa carta responde, melhor do que eu poderia fazer, às suspeitas que eu começo a compreender, Sr. Conde, (...),70

O Conde não só se convence de que estava enganado como também oferece a embaixada da Dinamarca se Kean tiver problemas com a polícia. Desculpando-se, sai. Parece que tudo está dando certo para o ator, mas entra

\footnotetext{
${ }^{69}$ Id. Ibid., pp. 297-298.

${ }^{70}$ Id. Ibid., pp. 300-301.
} 
então o guarda, o mesmo que já o ajudara. A contragosto, vem para prendê-lo, por ter insultado um Príncipe real e um membro do Parlamento. Explica a Kean que deve levá-lo e selar seus aposentos. $O$ ator diz que há uma dama ali: Miss Anna Damby está escondida na saleta. O guarda, compreensivo, promete deixar que eles se despeçam e que ela saia com o rosto escondido, sem ser revistada. Quando o policial se retira, Kean suplica a Anna que ela empreste seu casaco à Duquesa. A jovem concorda, e Kean the agradece. Porém, ao procurar Eléna, ela desapareceu. Ele acha que ela se matou, jogando-se no rio. Contudo, o Príncipe aparece com duas notícias: Eléna está salva (ele deixara uma gôndola sob as janelas de Kean para qualquer eventualidade) e ele obteve do rei uma comutação da pena do amigo - ao invés da prisão, um ano de exílio. Kean diz que então vai para Nova York, e Anna se surpreende:

"KEAN - Partirei em uma hora.

ANNA, se aproximando de Kean - Ah! Meu Deus!

KEAN - O navio que devo tomar está designado?

O PRÍNCIPE - Não; aquele que melhor vos convier.

KEAN - Eu escolho o Washington.

ANNA, se apoiando sobre Kean - Kean!

O PRÍNCIPE - E eu espero, senhor, que o ar da América vos refresque o cérebro e vos torne mais sadio.

KEAN - Pretendo ali me casar, meu senhor.

ANNA - Ah!

O PRÍNCIPE - Quem é esta bela jovem?

KEAN - Miss Anna Damby, contratada a partir de hoje para interpretar os primeiros papéis no teatro de Nova York.

O PRÍNCIPE - Miss Anna Damby? Ah! Eu adivinho... (Se inclinando) Miss!...

ANNA, fazendo uma reverência - Majestade...

SALOMON, entrando com as malas, e um pacote em mãos - Pronto!

KEAN - Bem, meu pobre Salomon?

SALOMON - Bem, mestre, estou pronto.

KEAN - Como?

SALOMON - O senhor não vai a Nova York?

KEAN - Sim.

SALOMON - Para lá se apresentar? 
KEAN - Sem dúvida.

SALOMON - Bem, no momento em que fizerdes comédias, precisareis de um ponto?

KEAN, a Salomon e a Anna - Ah! Sois meus únicos, meus dois verdadeiros amigos!

O PRÍNCIPE - Sois um ingrato, senhor Kean.

KEAN, se jogando em seus braços - Que Vossa Alteza me perdoe!

$$
\text { FIM",71 }^{, 71}
$$

É um final feliz para o astro inglês, que mudará de vida, espera-se, com a companhia de Miss Anna.

Podemos perceber uma vasta gama de elementos do melodrama na obra de Dumas: a virtude re-estabelecida no final, as reviravoltas, portas secretas, cartas urgentes, mascarados, coincidências, o leque perdido (que evoca inclusive o lenço de Desdêmona). Mas o elemento moralizante é atenuado em prol da exuberante personalidade do protagonista. Como afirma Prado,

"O teatro de Alexandre Dumas não perde tempo com reflexões morais, divagações filosóficas, desenvolvimentos psicológicos. É puro enredo, pura ação, puro efeito melodramático". ${ }^{72}$

A análise da peça traz em seu bojo uma problemática: o que há de Otelo no texto de Dumas? Na verdade, como pudemos perceber pelo resumo do enredo, não há uma predominância da personagem Otelo na composição de Kean, apesar do aviso que este faz a Eléna. É certo que as referências existem, e se coadunam com os dados reais da carreira do ator.

Porém, há uma preponderância de dois outros papéis da carreira de Kean na peça: Romeu, da peça Romeu e Julieta - que tem um trecho encenado - e Falstaff, não só pela relação dúbia de amizade que Kean tem com o príncipe, que lembra em parte a relação entre Falstaff e Hal nos Henrique IV partes I e II, mas também pelo seu espírito festivo mas ferino.

\footnotetext{
${ }^{71}$ Id. Ibid., pp- 304-305.

${ }^{72}$ PRADO, Décio de Almeida. João Caetano. São Paulo, Perspectiva/EDUSP, 1972, p. 40.
} 
No século XX, Jean Paul Sartre escreveria uma versão da peça mais fartamente calcada em Otelo. Não apenas é essa a peça que Kean encena mas também há um outro longo trecho que seria uma aula de Kean a Anna, no qual eles ensaiam uma cena entre Otelo e Desdêmona. Mas logicamente João Caetano não tinha acesso a essa versão. Obviamente, o texto por ele levado à cena deveria seguir as indicações originais de Dumas. Contudo, no levantamento de Décio de Almeida Prado dos jornais da época, críticos como Justiniano José da Rocha comentam a encenação de João Caetano, em 1841, com alguns elogios similares aos recebidos por Lemaître ao criar o papel:

"Não é exagero o que vai dito, estimável leitor: se quiserdes ir ao Covent Garden, ver Kean preparar-se no seu camarim, aparecer em cena e representar Otelo, ide ao teatro $\mathrm{S}$. Francisco, que assim o quiseram Dumas e o Sr. João Caetano. (...) O Sr. João Caetano esteve admirável. Nunca o vimos tão alto, tão livre de defeitos, tão original, como em a noite de antes de ontem. Parece que Dumas compôs esse papel para ser representado pelo Sr. João Caetano, e temos para nós que o próprio Kean não o representaria melhor! No $2^{\circ}$ e $4^{\circ}$ ato esteve o beneficiado acima de toda a expressão; a sua entrada no $1^{\circ}$ ato é magnífica; o Sr. João Caetano mostra-se polido como um dândi (...) mais adiante ei-lo de turbante representando Otelo."73

Décio até indica que

“(...) [o crítico faz] algumas restrições, não quanto ao desempenho de Kean, mas do Otelo: 'Assim é que sendo o Sr. João Caetano feliz em representar Kean, não o foi em imitar a representação desse ator no papel de Otelo. Depois de alguns versos declamados com ênfase e energia, quando era preciso concentrar em si todas as forças, contrair os nervos e fazer partir do íntimo d'alma essa brilhante exclamação: - 'Por que nos seus desertos africanos/ Otelo não morreu desconhecido?' o sr João Caetano pretende suprir a falta de energia de suas expressões com o retumbante da voz; e carregando com força nessas palavras, e dando aos

\footnotetext{
${ }^{73}$ Apud PRADO, Décio de Almeida. João Caetano. São Paulo, Perspectiva/EDUSP, 1972, p. 49.
} 
sons uma elasticidade exagerada, e erguendo os braços e encurvando-os acima da cabeça, declama esses dois versos com uma voz que mais parece da buzina da morte em sexta-feira de passos do que de um homem que maldiz sua sorte." 74

Essas críticas não podem se referir ao texto original de Dumas. A própria citação não é encontrada em Shakespeare, a versão que Dumas utilizaria, mas em Ducis. Parece claro que alguma modificação Kean sofreu. Se foi durante a tradução / adaptação, de J. M. de Souza Lobo e de José Antônio de Freitas, ou se foi uma escolha do próprio João Caetano para aproveitar o sucesso de um papel que era seu carro-chefe, esta é uma pergunta para a qual ainda temos que procurar uma resposta.

O que podemos ter certeza é de que Kean foi outra personagem de muito sucesso na carreira do ator brasileiro. De todo o repertório romântico que encenou, muitas vezes ao mesmo tempo em que as tragédias neoclássicas, foi um dos poucos papéis ao qual muitas referências são feitas, tanto pelo próprio João Caetano, quanto por críticos e escritores do período. Hessel e Raeders chegam a afirmar:

“(...) a darmos crédito ao testemunho de seus contemporâneos, em nenhum drama do teatro romântico montado e representado pelo famoso ator brasileiro, atingiu ela as culminâncias a que se alcandorou em Kean". ${ }^{75}$

Há duas referências de João Caetano a Kean nas Lições Dramáticas. A primeira se refere ao ator inglês em si, mas de forma um tanto genérica, explicando que ele e outros deram muita importância ao jogo fisionômico. A segunda referência, porém, é um comentário sobre uma fala da peça de Dumas:

\footnotetext{
${ }^{74}$ Id. Ibid., p. 50

${ }^{75}$ HESSEL, Lothar \& RAEDERS, Georges. O Teatro Brasileiro sob D. Pedro II. Porto Alegre, UFRGS / Instituto Estadual do Livro, 1979, p. 22.
} 
"O gênio e a arte são como as estrelas em um céu nebuloso, e como estas não brilham pela intensidade das nuvens, aqueles são ofuscados no ator, cuja conduta religiosa e civil, cujos títulos de honesto e bom cidadão não forem bem pronunciados e adquiridos, e conquanto os senhores me tenham ouvido dizer na comédia Kean ou a desordem e o gênio, no momento em que o velho Salomon desperta o famoso ator britânico do sono da embriaguez, arrancando-lhe da mão uma garrafa de rum, dirigindo-Ihe estas palavras: - Ah! Senhor, senhor, vós vos matais com esta vida de deboche e orgia!... - O que queres, meu amigo, é preciso que um ator conheça todas as paixões para bem poder exprimi-las: eu estudo-as em mim próprio, porque é o meio de as saber de cor. Esta idéia de Alexandre Dumas, asseguro-lhes, senhores, que não é exata; foi um colorido que ele procurou dar aos vícios do ator que apresenta no primeiro plano da sua comédia, procurando por este modo que o público esquecesse a má conduta do homem para só apreciar o grande gênio da cena da Inglaterra; e ainda que Kean mereceu a estima e proteção do príncipe de Gales, é sabido que não deixava por isso de perder muito no conceito das pessoas gradas pela sua vida desregrada e repreensível."76

A crítica a Dumas é comentada por Décio de Almeida Prado:

"Kean foi um dos maiores sucessos da mocidade de João Caetano. Mas este, enquanto legislador clássico, não foge à obrigação de pôr o drama herético de Dumas em seu devido lugar."77

\subsection{4. - OS OTELOS NO REPERTÓRIO DE JOÃO CAETANO}

Dono de um extenso repertório, João Caetano, ao que se vê, confrontou-se mais de uma vez com o papel de Otelo, em diversos tipos de adaptação. De todos os casos, surge sempre o triunfo da composição do protagonista da peça de Ducis, que apesar de ter sido feita no início da carreira do ator, juntamente com outras tragédias neoclássicas, gozou de uma popularidade permanente,

\footnotetext{
${ }^{76}$ SANTOS, João Caetano dos. Op. Cit., p. 56.
} 
não apenas levando o ator a encenar a obra várias vezes em temporadas seguintes, como também se transformando em uma referência à qual fariam alusões dramaturgos como Martins Pena e Joaquim Manuel de Macedo em suas próprias obras.

Nas palavras de Salvador de Mendonça:

\begin{abstract}
"Vi Henry Irving na Inglaterra e Edwin Booth nos Estados Unidos nos papéis de Hamleto e Otelo: ambos pareceram-me inferiores ao ator brasileiro: Irving por muito convencional e amaneirado e Booth por menos intenso e muito declamador. Se levarmos em conta que nos dramas de Shakespeare, Booth e Irving tinham as próprias palavras do autor genial, e Rossi e Salvini boas adaptações italianas, ao passo que o ator brasileiro só dispunha de retraduções da obra descorada de Ducis, ficará bem patente a primazia de quem ao enfrentar tais colossos dramáticos, apoderava-se deles e os erguia à altura da majestosa criação original." ${ }^{, 78}$
\end{abstract}

Porém é preciso lembrar que João Caetano não se contentou apenas com a personagem de Ducis, elencando uma série de protagonistas nos quais Otelo era ou um pretexto, - caso de Kean -, ou uma inspiração, - como Orosmane e outros papéis menores que formaram um ciclo de estudo do ciúme, do qual podemos destacar Fayel, herói da obra homônima de Baculard d'Arnaud (17181805) escrita em 1778. João Caetano encenou a versão traduzida por João Batista Gomes Júnior em Portugal, em 1803.

Nesta peça, o protagonista é um violento marido desconfiado casado com Gabriella, a qual se apaixonara pelo nobre Cuci antes de casar-se. Tendo os pais de ambos os enamorados se desentendido, o jovem partira para as Cruzadas, e a moça se casara. Ao voltar, Cuci descobre que sua amada já não podia pertencer-lhe. Ciumento e vingativo, apesar de não ter sido traído de fato, Fayel duela com Cuci e o mata. Após assassinar também Gabriella, ele se suicida.

${ }^{77}$ PRADO, Décio de Almeida. João Caetano e a Arte do Ator. São Paulo, Ática, 1984, p. 131. 
Um elemento interessante do texto é a descrição do caráter de Fayel, que retoma imagens utilizadas em Othello, como podemos perceber nos exemplos a seguir:

"FAYEL- (...) Sou um bárbaro, um tigre, que esfaimado

Rugindo ruidoso despedaça

A infeliz presa nas cruentas garras". ${ }^{79}$

Mais à frente, encontramos:

"IZAURE - Não sei o que o instiga a tais excessos.

Negras fúrias parece que o dominam.

Qual sanhudo Leão ardendo em raiva,

Que chamejando devorante fogo

Se aparelha, afiando os fortes dentes

Para exercer cruel carniceria,

Assim seu coração abrazeado

De furor em furor se precipita.

Nunca su'alma foi tão vivamente

Despedaçada por fatais ciúmes". ${ }^{80}$

Finalmente, a protagonista Gabriella afirma a seu pai, Vergi:

"Ao tigre mais feroz m'encadeaste,

Eu não posso domar a sua raiva". ${ }^{81}$

O repertório de João Caetano também é considerável ao constatarmos que seus "outros Otelos" também são peças que retornariam aos palcos cariocas continuamente ao longo do século XIX. Tanto Zaíra quanto Kean conheceram numerosas encenações, sendo que o grande trágico italiano Ernesto Rossi abriria sua temporada no Rio de Janeiro, em 1871, exatamente com Kean, papel que Enrico Cuneo e Eduardo Brazão também desempenhariam.

\footnotetext{
${ }^{78}$ Apud PRADO, Décio de Almeida. João Caetano. São Paulo, Perspectiva/EDUSP, 1972, p. 189.

79 D’ARNAUD, Baculard. Fayel, 2a ed., trad. João Batista Gomes. Porto, Oficina de Antonio Álvares Ribeiro, 1803, p. 16.

${ }^{80}$ Id. Ibid., p. 27.
} 
A vinda das companhias italianas a partir de 1870, com seus muitos Otelos, seria uma página importante na entrada da personagem no Brasil, como veremos a seguir. Mas serviriam também, muitas vezes, para resgatar a memória do talento de João Caetano, em muitos artigos comparativos escritos por quem vira e até por quem não vira o ator brasileiro e seu Otelo. Como afirma J.R.M., de A Vida Fluminense, ao ver Rossi em 1871:

"A partir do $2^{\circ}$ ato essa geração que vai encanecendo progressivamente, rejuvenescia ao recordar cenas, tão conhecidas, do bom tempo em que o Brasil tinha um teatro e um artista!"82

O crítico de O Guarany afirma:

"Não vimos João Caetano, a estrela brilhante e gloriosa do nosso teatro; quem admirou, porém, aquele talento, afiança-nos ser o mesmo que Rossi.

"Não nos admira esse fenômeno; no mundo intelectual, como no mundo físico, há leis gerais que determinam que causas semelhantes produzirão fatos semelhantes, e João Caetano era um gênio como o é Ernesto Rossi." 83

Os críticos contrários a Rossi também se lembram do ator nacional, não para equipará-lo ao italiano, mas para elevá-lo acima deste. Assim, afirma J. J. da Cunha Vieira Souto:

\begin{abstract}
"Possuído de inexplicável contentamento, louco, por assim dizer, de alegria patriótica, tenho em tua ausência sido testemunha da justiça que, a despeito de quase toda a imprensa, tem feito o nosso inteligente público, mostrando a Ernesto Rossi, por seu nenhum entusiasmo que, apesar de toda a reputação européia de que veio precedido, ele não pode disputar ao gênio artístico de João Caetano a mesma glória, quanto mais a primazia." 84
\end{abstract}

\footnotetext{
${ }^{81}$ Id. Ibid., p. 34.

${ }^{82}$ A Vida Fluminense, ano 4, no. 176, 13/05/1871, p. 570.

${ }^{83}$ O Guarany, ano I, no. 16, 03/05/1871, p. 6.

${ }^{84}$ O Guarany, ano I, no. $18,14 / 05 / 1871$, p. 6.
} 
Ferreira de Araújo recorda o longo hiato entre João Caetano e a nova geração de trágicos italianos:

"Era imensa a ansiedade pública quando estreou A. Ristori. No horizonte de nossos teatros brilhara, anos antes, um astro de vivíssima luz; luz própria, que the vinha de dentro, que não tinha sido bebida, não era refletida de nenhum dos focos radiantes que iluminam o céu das artes na velha e culta Europa. João Caetano fizera estremecer as platéias extasiadas ante o seu gênio; em torno dele, a não ser Estella e Ludovina, espelhos de aço polido, em que as irradiações do astro rei se refletiam, tudo o mais era sombra. Quando o anjo da morte empanou com suas asas negras o brilho daquela luz, a deusa da tragédia lançou sobre os ombros o crepe da viuvez e ninguém mais ousou tocar-lhe. (...)

"Erguem-se os amigos e admiradores de João Caetano, e com razão o fazem; E. Rossi veio mostrar aos que insultavam o nosso Talma, que eram qualidades o que eles chamavam defeitos, e que se João Caetano tivesse tido mestres e escola, como teve E. Rossi, o seu nome seria tão conhecido no mundo como o do maravilhoso artista, que ora nos extasia com seu surpreendente talento." 85

Assim, podemos perceber o alcance da impressão causada por João Caetano em seus conterrâneos, que mesmo após uma geração não se furtam a retomar seu exemplo como a glória do teatro brasileiro.

Após a morte do ator brasileiro, foi preciso esperar algum tempo - mais especificamente, até 1871 - para que novos Otelos viessem sacudir a cena carioca, como veremos a seguir.

${ }^{85}$ O Guarany, ano I, no. $19,21 / 05 / 1871$, p. 4. 


\title{
1.2.5. - AS COMPANHIAS ESTRANGEIRAS
}

\author{
"Para nós, não sabendo qual preferir, apenas podemos manifestar \\ a nossa admiração dizendo - que o público fluminense seria \\ - mais feliz dos públicos se, eternamente, visse representar às segundas, \\ quartas e sextas-feiras, Ernesto Rossi, e às terças, quintas e sábados, \\ Thomaz Salvini - Restavam os domingos para o descanso, porque, \\ se eles não existissem nas semanas, o frenesi do entusiasmo \\ enlouqueceria aos freqüentadores do teatro italiano." \\ aV, crítico do Diário do Rio de Janeiro
}

A presença das companhias estrangeiras no Brasil remonta à vinda da Família Real portuguesa ao Rio de Janeiro em 1808 e à construção do Teatro São João, posteriormente Teatro São Pedro e Constitucional Fluminense. Dentre as várias companhias que aportaram no Brasil, algumas nos interessam mais de perto por trazerem em seu repertório versões de Othello.

Na primeira referência a uma encenação, mesmo parcial, de Othello no Rio de Janeiro, contudo, não há menção a uma companhia estrangeira. Essa referência é encontrada em 1834, quando o seguinte anúncio do Teatro Constitucional Fluminense é publicado no Jornal do Comércio:

"Sábado 25 de janeiro de 1834, em benefício de Daniel Trench, Administrador do referido Teatro, a Companhia Cômica apresentará em cena um bem delineado Espetáculo (...) Seguir-se-ão duas cenas da Tragédia Inglesa OTHELLO, representadas por uma Sociedade curiosa. N.B. O resto do divertimento será anunciado pelos cartazes. - DANIEL TRENCH has the honour to announce that for this night only will be presented in the English Language, part of the celebrated Tragedy of OTHELLO; two scenes of which will be performed by two Gentlemen Amateurs, who have kindly proffered their assistance on this occasion. D. TRENCH ever anxious to select what is most esteemed in the field of Literature by the Public, trusts that this selection from the 'immortal Shakspear' will meet with the approbation of his Countrymen and the 
generous protection of the Public at large. Several POPULAR SONGS in

English by Amateurs will precede one of the most esteemed Farces". ${ }^{86}$

Chama a atenção parte do anúncio estar em inglês.

Pires de Almeida afirma que o espetáculo foi feito por um grupo de amadores, organizado por um sobrinho do contra-almirante Michael Seymour. ${ }^{87}$ É interessante pensar que Otelo, que viria a ser um papel tão explorado por artistas profissionais do século XIX no Rio de Janeiro, tenha iniciado sua trajetória nos palcos cariocas encenado por amadores. Vale ressaltar também que, apesar da posterior dominância do texto de Ducis, ao menos de forma documentada o primeiro Otelo encenado no Brasil recitou os versos de Shakespeare - e em inglês. Mas a apresentação parece realmente ter se resumido a duas cenas, apresentadas numa única noite, visto que não há anúncios de repetição do programa posteriormente.

Em 1838, o ator espanhol Adolfo Ribelle desembarca no Rio de Janeiro para uma curta estada, e aproveita para fazer uma apresentação do Otelo de Ducis, parte de seu repertório, no Teatro de São Pedro de Alcântara, como explicam os anúncios:

"Chegando a esta capital D. Adolfo Ribelle, um dos primeiros trágicos da Espanha, em companhia de D. Maria del Carmen, jovem atriz sua discípula, e tendo de se demorar poucos dias enquanto o navio se prepara a seguir viagem para o porto do seu destino, tem a honra de anunciar ao respeitável público desta capital, que no dia quarta feira 20 do corrente, dará uma e única representação que será distribuída de maneira seguinte: $4^{\circ}$ e $5^{\circ}$ ato - De Otelo -, Sublime tragédia do insigne Ducis, traduzida em versos Castelhanos. A companhia nacional, por obséquio ao beneficiado, representará uma de suas farsas em que entra o ator João Caetano dos Santos; e terminará o espetáculo com um drama em um ato, denominado Al Maestro Cuchillada, (...)".8

\footnotetext{
${ }^{86}$ TEATRO constitucional fluminense. Jornal do Comércio, 24/01/1834, p.2.

${ }^{87}$ PIRES DE ALMEIDA, Brazil - Theatro, 2o. fascículo, 1903-1906, p. 620.

${ }^{88}$ De S. Pedro d'Alcantara. Diário do Rio de Janeiro, 19 e 20/06/1838, p. 2 (Teatros) e Jornal do Comércio, 19 e 20/06/1838, p.3 e pp.3-4 (Teatros).
} 
Vale ressaltar a presença, no programa, de João Caetano e sua companhia, em um momento no qual o próprio ator brasileiro já media forças com o papel do mouro de Veneza.

Em 1843, um anúncio no Jornal do Comércio indica uma apresentação de José Lapuerta e sua companhia espanhola no Teatro São Pedro, em 15 de fevereiro. ${ }^{89}$ Não há documentação sobre outros espetáculos.

Após estas primeiras representações, segue-se um vácuo de quase três décadas, só rompido com as encenações da ópera de Rossini sobre o mesmo tema (da qual trataremos posteriormente), até que os italianos viessem a tomar o Rio de Janeiro de assalto com suas atuações do Othello shakespeariano, traduzido para o italiano.

\subsubsection{1 - AS COMPANHIAS ITALIANAS E PORTUGUESAS}

"A religião do teatro Ao ator manda que sinta

Veneração e respeito Pela trindade distinta.

Ristori, Salvini e Rossi Orgulho do mundo inteiro São três talentos distintos (Mostrando Rossi) Mas só um deus verdadeiro." Vasques, ator brasileiro, em recepção a Rossi, 1871

Se, por um lado, os italianos demorariam a conhecer Shakespeare, e o fariam basicamente através dos franceses e suas correções no século XVIII (em especial via Voltaire e Ducis), no século XIX a relação dos atores italianos com

\footnotetext{
${ }^{89}$ Anúncios. Jornal do Comércio, 15/02/1843, p. 4.
} 
o bardo inglês daria um grande salto, culminando nas grandes estrelas internacionais cujos repertórios sempre incluiriam obras shakespearianas.

Não foi um caminho tranqüilo, contudo. Após traduções e adaptações sofríveis ao estilo neoclássico, Shakespeare começaria a ter tradutores mais fiéis e atores interessados em versões mais próximas ao original, começando por Antonio Morrocchesi no final do século XVIII. De início, porém, a reação do público foi fria, e assim continuaria até o advento do Romantismo no país.

Em 1816 - ano da ópera Othelo, de Rossini -, Madame de Staël conclamaria os escritores italianos a buscar inspiração em Shakespeare e em outros autores ingleses e alemães. Ainda assim, a tradução de Michele Leoni feita entre 1819 e 1822 continuava simplificando o enredo da peça e adequando-a às regras das unidades neoclássicas, por exemplo.

$\mathrm{Na}$ década de 1830 várias novas traduções mais fidedignas surgiriam. Em 1842, o grande ator Gustavo Modena - que seria o mestre tanto de Rossi quanto de Salvini - aventurou-se no papel do mouro, seguindo a antiga versão de Leoni como base mas trazendo-a mais próximo de Shakespeare.

\footnotetext{
"Muitos anos mais tarde Modena descreveu a seu aluno Rossi a catastrófica estréia dessa produção no Teatro Re de Milão. Assim que Roderigo começou a gritar por Brabâncio a platéia começou a sussurrar: 'O que é isso? Uma tragédia ou uma farsa?' Quando Brabâncio apareceu no balcão sonolento e com as roupas em desordem foi saudado com risadas, e depois com vaias e assobios. A cortina foi baixada e o espetáculo terminou, de acordo com Modena, antes mesmo de ele ter aparecido em cena.
}

"Notícias dos jornais de Milão do período contam uma história diferente, e menos gloriosa para o ator. De acordo com eles, o espetáculo seguiu até o fim, mas apesar dos esforços do ator principal foi recebido pela platéia com 
completa indiferença. De qualquer modo, Modena ficou suficientemente desencorajado para tentar encenar Shakespeare de novo". 90

Mesmo assim, o entusiasmo de Modena por Shakespeare daria frutos. Ele encorajaria e veria seus discípulos diretos triunfarem, com o texto traduzido por Giulio Carcano em 1852*, e entre 1856 e 1870 Shakespeare finalmente se estabeleceria no repertório das grandes companhias do país, que iniciavam um grande projeto de viajar o mundo para mostrar suas encenações. A primeira atriz que triunfaria no exterior com um papel shakespeariano seria Adelaide Ristori, que já em 1855 fora ovacionada em Paris. Seu repertório incluía os papéis de Medéia, na peça de Ernest Legouvé, e Fedra, o que a levou a investir na figura de Lady Macbeth.

Apesar do fato de que as excursões de companhias teatrais não eram exatamente uma novidade - desde a época de Shakespeare, por exemplo, os atores ingleses cruzavam o Canal da Mancha para apresentações -, Ristori foi a primeira estrela italiana a aventurar-se em carreira internacional, começando pela França de sua rival Rachel, chegando à Inglaterra e daí - literalmente partindo para o mundo. Podemos afirmar que Ristori e sua companhia prepararam o caminho para Rossi, Salvini e os outros astros italianos no exterior, inclusive nos países de língua inglesa, pouco acostumados a ouvir seu principal autor em outra língua. As recepções calorosas de Ristori na Inglaterra e nos Estados Unidos, somadas ao profundo interesse que a atriz nutriu pelo papel de Lady Macbeth, levaram-na inclusive a estudar a língua inglesa com afinco para poder representar a obra no original (Rossi seguiria os mesmos passos com Rei Lear).

As companhias italianas começaram a desembarcar no Brasil em 1869, quando Adelaide Ristori (1821-1906) chegou ao Rio de Janeiro pela primeira vez (ela voltaria em 1874). Entre as duas visitas da grande atriz o Rio de Janeiro conheceria os dois maiores atores trágicos italianos da época: Ernesto

\footnotetext{
${ }^{90}$ CARLSON, Marvin. The Italian Shakespearians. London, Folger Books, 1985, p. 18.

* A tradução de Carcano fora encomendada por Rossi e foi completada nesse ano. Rossi, porém, havia dissolvido sua companhia e estava a serviço da Reale Sarda, que não tinha interesse em Shakespeare.
} 
Rossi (1827-1896) e Tommaso Salvini (1829-1915). Ambos chegaram ao Brasil em 1871, Rossi em 05 de maio e Salvini em 15 de setembro.

Nunca é demais ressaltar que Ristori, Rossi e Salvini eram três dos maiores nomes do teatro europeu do período, tendo sido, pois, um privilégio para a platéia carioca a oportunidade de vê-los em cena. Suas companhias rodaram o mundo em longas viagens para a América do Sul, os Estados Unidos, a França, a Inglaterra, a Rússia e mesmo a Turquia (Rossi), um hábito que seria seguido por outras companhias nas décadas seguintes e que traria outros grandes atores ao Brasil. Além disso, os três artistas não só tinham papéis shakespearianos em seu repertório como, via de regra, esses papéis eram os carros-chefes de suas temporadas: Adelaide Ristori notabilizou-se como Lady Macbeth (apesar de não a haver representado no Brasil em 1869); Salvini como Otelo; e Rossi, especialmente como Hamlet, apesar de ter também feito outras personagens de Shakespeare de forma memorável, como Otelo, Lear e Coriolano. Nos Estados Unidos, Rossi sofreu a comparação com Salvini, que o precedera em uma temporada, e cujo Otelo havia sido reconhecido como estupendo. Por conta disso, Rossi desistiu de apresentar seu Otelo em algumas das cidades do roteiro. No Brasil, contudo, Rossi desembarcou antes, o que Ihe permitiu mostrar seu repertório sem temor.

É impossível subestimar a importância dos atores italianos para a cena carioca do momento. Em primeiro lugar, como bem aponta Lafaiete Silva ao tratar de Salvini e Rossi,

\footnotetext{
"Devemos aos dois grandes artistas o conhecimento das peças de Shakespeare, como as fizera o imortal poeta inglês, pois o Hamleto e o Otelo, representados por Lapuerta e João Caetano, eram traduções infidelíssimas de Ducis". 91
}

Finalmente, pois, temos a encenação completa do Otelo shakespeariano no país, ainda que em italiano. Devemos, pois, a esses artistas, o crescente 
conhecimento do público brasileiro em relação ao autor inglês e sua obra, lentamente substituindo a versão de Ducis nas mentes brasileiras.

Um outro dado importante é a concomitância das apresentações de Salvini e Rossi, em 1871, e depois de Emanuel e dos portugueses Álvaro Filipe Ferreira e Brazão, entre 1885 e 1887. A possibilidade de acesso a várias representações da mesma obra enriquece a crítica do período, levando a comparações e reflexões inexistentes até então. Por exemplo, em se tratando de Salvini e Rossi, Lafaiete Silva ressalta:

\begin{abstract}
"A crítica nacional dividiu-se no julgamento dos dois notáveis artistas. Um dos grandes admiradores de Salvini foi Joaquim Nabuco, que escreveu ter ele dado à interpretação do Hamlet uma beleza desconhecida em nosso teatro. Salvador de Mendonça inseriu excelentes artigos críticos "n’A República" sobre o Rossi.
\end{abstract}

"E ainda a respeito dos dois artistas que tiveram o mesmo mestre, Gustavo Modena, se manifestaram Francisco Otaviano, José de Alencar, Luiz Guimarães Júnior, Joaquim Serra e Machado de Assis". ${ }^{92}$

Devemos ainda ressaltar a presença das companhias portuguesas como as de Eduardo Brazão (ou Brasão) e de Álvaro Filipe Ferreira, responsáveis pela inauguração da encenação, no Brasil, de textos de Shakespeare traduzidos para o português diretamente do original. Afinal, uma companhia brasileira apenas encenaria uma obra de Shakespeare em português, na íntegra, em 1938 ( Teatro do Estudante do Brasil - TEB, com Romeu e Julieta).

\title{
ERNESTO ROSSI
}

“Há trinta anos represento esse bendito personagem e ele ainda me faz suar. Não aprendi a arte de fazer sentir sem sentir,

\footnotetext{
${ }^{91}$ SILVA, Lafaiete. História do Teatro Brasileiro. Rio de Janeiro, Ministério da Educação, 1938, p. 366.

${ }^{92}$ Id. Ibid., p. 366.
} 
"Rossi era irresistível, mas não por essa força espontânea e sim pela estrutura lógica do sentimento, pela coerência do plano do papel, pela tranqüilidade da sua execução e a segurança, na sua maestria e no seu poder de produzir efeito."

Constantin Stanislavski

"Ele tinha um único defeito - ser correto demais."

Théophile Gautier

Ernesto Rossi nasceu em Livorno em 1829 e morreu em 1896, consagrado pelo público e pela crítica. Abraçou cedo a carreira artística, contra a vontade de seu pai. Já em 1846 está na Compagnia Calloud-Fusani-Marchi, onde é descoberto por Gustavo Modena. Após passar pela companhia de Giovanni Leigheb, entra na Compagnia Reale Sarda, e em 1855 excursiona a Paris junto a Adelaide Ristori. A partir daí funda sua própria companhia, cujo repertório eclético incluiria, além de Shakespeare, Schiller e Goldoni.

A natureza artística, aliada a um estudo contínuo e profundo e ao conhecimento de várias línguas, rendeu-lhe logo muitos frutos. Estudou inglês para ler Shakespeare no original, colecionou edições do bardo em diferentes idiomas, e compôs memoravelmente os papéis de Hamlet, Otelo, Romeu, Lear e Júlio César. A propósito do autor inglês, chegou a afirmar:

"Aquele é um santo para mim, mais santo do que todos os santos, porque faz milagres também depois de tantos anos de sua morte; certamente exige a máxima devoção e não se contenta com um culto superficial". ${ }^{93}$

Rossi foi um grande viajante, colhendo triunfos por onde passou. Foi condecorado pelo rei da Holanda, aplaudido pelo imperador Guilherme I da Prússia, e entusiasmou os russos a partir de 1877. Também apresentou seu talento na Áustria, Bélgica, Dinamarca, Espanha, Portugal, Turquia, Inglaterra,

\footnotetext{
${ }^{93}$ Apud LANCELLOTTI, Arturo. I Sovrani della Scena. Roma, Editrice Faro, s/d, pp. 173-174.
} 
Estados Unidos e Brasil. Suas memórias, em três grossos volumes, dão conta dessas experiências.

Em suas duas viagens ao Rio de Janeiro, Rossi representou vários papéis shakespearianos. Em 1871, trouxe Otelo (primeira representação em 11/05), cujo protagonista encarnava desde 1856; Romeu e Julieta (22/05); Hamlet (12/06); e Macbeth (21/06). Em 1979, além destas obras (com estréias respectivamente em 25/06, 09/07, 23/07 e 11/07), encenou Rei Lear (primeira apresentação em 03/07), Ricardo III (19/07), Coriolano (29/07) e O Mercador de Veneza (06/08). Sua estréia, porém, nos palcos brasileiros ocorreu no Rio de Janeiro no dia 08 de maio de 1871, no Teatro Lírico Fluminense, com a peça Kean, de Alexandre Dumas, a mesma que fora representada por João Caetano e que tantas referências faz à obra shakespeariana.

Sua chegada em 1871 foi precedida da publicação de sua biografia, em capítulos, pelo periódico A Vida Fluminense, em tom altamente elogioso*. Assim, Rossi desembarcou no Brasil para apresentar-se a um público com altas expectativas.

A recepção de Rossi foi um tanto polêmica; a maior parte da imprensa colocouse ao lado do artista, mas vozes dissonantes também condenaram seu estilo de interpretação como exagerado, ou até "monstruosidade", na palavra de Augusto de Castro, crítico do Jornal do Comércio que iniciou grande discussão*. O que não se pode negar é o monopólio de atenção que 0 ator italiano conquistou no período: os jornais não se cansam de falar dele.

Há comentários dos mais positivos, como o seguinte, que expressa bem a repercussão da estréia de Rossi:

"O público do Rio de Janeiro sabe finalmente o que é um ator dramático.

\footnotetext{
* Os artigos, assinados por A. de A., estão em: Vida Fluminense, ano 4, no. 162, 04/02/1871, p. 458; no. $172,15 / 04 / 1871$, p. 538; no. 173, 22/04/1871, p. 547; no. 175, 06?05?1871, pp. 562-563.

* O termo está em 'Cartas de um Caipira'. Jornal do Comércio, 27/06/1879, p. 1 (Folhetim) e nos artigos seguintes, tamanha a polêmica suscitada.
} 
"Rossi estreou, a oito, e tão viva foi a impressão que a força irresistível do seu gênio causou sobre o exigente auditório que afluíra naquela noite à sala do teatro lírico, que de então para cá tem o grande artista italiano sido o assunto principal de todas as conversações, o alvo constante dos maiores louvores. Todos falam nele. Os que já o viram tributam-lhe veneração entusiástica: os que ainda não tiveram essa ventura prometem não perder no futuro uma só de suas representações.

"A imprensa diária pela sua parte tem sido pródiga de apreciações, onde se faz completa justiça ao talento excepcional do nosso ilustre hóspede: Luiz Guimarães Júnior, César Muzzio, e França Júnior dedicaram-lhe folhetins onde se trata quase exclusivamente do artista, cuja celebridade é hoje reconhecida pelas cidades mais cultas da velha Europa; e até os nossos atores, faz gosto dizê-lo, folgam de ver em Ernesto Rossi o modelo mais perfeito que a escola possa apresentar aos que desejam iniciar-se nos insondáveis mistérios da arte dramática. (...)

"Das ovações que acolheram o "Othelo" de Shakespeare não falarei detidamente. Se jamais entre nós o entusiasmo rebentou espontâneo, clamoroso, frenético, delirante: se jamais um artista soube magnetizar o seu auditório a ponto de obrigá-lo insensivelmente a erguer-se da cadeira e soltar um desses bravos que nascem do coração, para virem rebentar nos lábios; esse entusiasmo foi na noite de 11, esse artista é Ernesto Rossi." 94

Alguns críticos demonstram seu entusiasmo com fervor, como Dias da Silva Júnior, do Diário de Notícias:

\footnotetext{
"Kean e Othelo são as duas faces porque se há revelado ao público aquele gênio. Fui vê-lo, e digo ao meu leitor que me não é possível descrever as sensações porque passou minh'alma diante do sublime da arte; as transfigurações daquela fisionomia e a revelação dos sentimentos são feitas com tal expressão de verdade, que o coração do espectador sente com o ator a paixão e a dor que eles traduzem."
}

\footnotetext{
${ }^{94}$ A Vida Fluminense, ano 4, no. 176, 13/05/1871, p. 570.

${ }^{95}$ Filagranas. Diário de Notícias, 23/05/1871, p. 1.
} 
Miranda de Azevedo, de O Guarany, também publica artigo elogioso:

"Othelo subjugando Yago, é um desses lances que o mais inspirado pintor é incapaz de reproduzir com a mesma verdade e beleza como o faz Rossi.

"É o filho do deserto, que não conhece outra lei a não ser sua paixão, que leva de vencida o inimigo traidor, é o leão altivo que subjuga, triunfante e iroso, o tigre que ousou disputar-lhe a sua presa; a expressão feroz que anima o semblante de Rossi nesse momento, traduzem bem 0 ato que executa.

"Rossi vai em uma progressão crescente de triunfos; em cada lance, em cada cena, ele excede-se a si próprio." ${ }^{96}$

Clímaco dos Reis é contundente:

"Nos últimos três atos de Othelo é onde há mais de maravilhoso, onde os dotes artísticos do trágico se apresentam em todo o fulgor. As situações são surpreendentes, e são nesses quadros vivos que Rossi logra para a sua coroa de verdadeiro artista novíssimas flores; cada frase é acompanhada da atitude mais eloqüente, mais expressiva que só o muito estudo guiado por muito gênio pode criar.. ${ }^{97}$

Ou, mais veemente ainda, o crítico X., da Semana llustrada:

"Depois do nosso último número, Rossi representou mais três peças em que foi calorosamente aplaudido. Mas a peça em que mais tem assombrado a platéia é o Othelo. Não se descreve, nem se analisa o que ele é; vê-se e aplaude-se... ou fica-se (como diz o Carniole) classificado perpetuamente entre as ostras e mexilhões." ${ }^{.98}$

V. de B. afirma, no mesmo periódico, algumas semanas depois:

\footnotetext{
${ }^{96}$ O Guarany, ano 1 , no. $16,03 / 05 / 1871$, p. 7.

${ }^{97}$ Diário de Notícias, 13/05/1871, p. 1.

${ }^{98}$ Semana Ilustrada, ano 11, no. 545, 21/05/1871, p. 4355.
} 
"Mérito tão singular, talento tão vigoroso, inteligência tão esplêndida não podem deixar de produzir entusiasmo em quem ama as manifestações de belo e do grandioso.

"E é por isso que o Lírico Fluminense torna-se o capitólio onde em todas as noites de representação é laureado de aplausos e de bravos espontâneos o eminente trágico italiano.

"Não sabemos se o ilustre artista tem detratores; é de presumir que os tenha entre invejosos, indiferentes ou vítimas do mau gosto." 99

O crítico, aqui, só pode estar sendo irônico, já que, desde a estréia, várias vozes contrárias a Rossi também vinham se manifestando na imprensa. Um bom exemplo é J. J. da Cunha Vieira Souto:

"Possuído de inexplicável contentamento, louco, por assim dizer, de alegria patriótica, tenho em tua ausência sido testemunha da justiça que, a despeito de quase toda a imprensa, tem feito o nosso inteligente público, mostrando a Ernesto Rossi, por seu nenhum entusiasmo que, apesar de toda a reputação européia de que veio precedido, ele não pode disputar ao gênio artístico de João Caetano a mesma glória, quanto mais a primazia.

"Entretanto, não quero dizer-te com isto que o povo fluminense desconhece o mérito daquele artista italiano, não; pelo contrário, na escola realista rende-lhe sempre merecidos encômios, mas daí a julgá-lo o non plus ultra da arte dramática vai também muita diferença."100

E, em outro artigo:

"Como, então, não havendo talento completo sem verdade, nem esta sem respeito as conveniências, Ernesto Rossi apresenta-se no Othelo mais como um energúmeno do que como um herói apaixonado? O que nos mostra ali este artista não é, por certo, uma dor humana nem semi-

\footnotetext{
99 Semana Ilustrada, ano 11, no. 548, 11/06/1871, pp. 4379 e 4382.
}

${ }^{100}$ O Guarany, ano I, no. 18, 14/05/1871, p. 6. 
bárbara; é a fúria da pantera, a quem se arranca os filhinhos: a cólera muda-se em furor, a brutalidade substitui o instinto e a alma cede ao corpo. Entretanto, segundo Aristotes [sic], a tragédia é a imitação de uma ação que, pelo terror (e não pelo horror) e piedade nos corrija de todas as paixões e Aristipe determina que para se mostrar no teatro a cólera, cujos efeitos facilmente tornam-se horrendos e asquerosos, deve-se abster, mais que em outro afeto, de exceder e até de igualar a verdade; além de que, a ação da inteligência sobre os movimentos é muito comum ao mundo. Quem não tem visto a dor, a alegria, o ciúme, todas as paixões humanas se conter, se regrar, e distribuir os gritos, os suspiros, as ameaças, de modo a ganhar as simpatias das testemunhas, quando as há? Pois se o mouro, já em parte, havia sido vencido pela civilização, se o intrigante Yago não lhe arrancara de todo a esperança, que motivo o impedia de guardar o equilíbrio que, em tal caso, conserva a alma e, por conseqüência o corpo, o que tanto concorria para a beleza moral e material da arte grega?"101

Outro crítico que defende tal posição, posteriormente, é Augusto de Castro, em artigos assinados por 'Felippe', no Jornal do Comércio:

"Ele, tão verdadeiro e natural em muitos dos outros papéis do seu vasto repertório (em alguns dos quais, por vezes, parece até inspirado por essa centelha divina)... no Othelo obedece como máquina inconsciente às estúpidas imposições dessa tradição pseudo-artística, que manda dar gritos e fazer gestos meramente convencionais, que tão somente exprimem... o que se concordou que exprimissem, gestos e gritos herdados dos tempos em que a arte nada era ainda, gritos e gestos falsíssimos e como tais repudiados por Garrick há cerca de cento e cinqüenta anos!" 102

O que críticos de ambas as facções - poderíamos assim chamá-las ressaltam é o fato de que as representações de Rossi atraem muito menos público do que poderiam ou deveriam, especialmente em 1871. Poucos artigos afirmam o contrário, e alguns silenciam.

\footnotetext{
${ }^{101}$ O Guarany, ano I, no. 22, 11/06/1871, p. 7.

102 Jornal do Comércio, 10/07/1879, p. 1.
} 
Apesar de raro, podemos encontrar finalmente artigos mais equilibrados, que nem exaltam Rossi como o maior ator do mundo, nem o detratam como um grande engano:

"A crítica imparcial e reta exige que digamos que essa representação esteve longe de fazer justiça à peça. Este não só sofreu bastante pelos cortes e modificações que Ihe deram, como também teve a infelicidade de não ser interpretada corretamente pelos artistas incumbidos dos papéis principais. (...)

"Quanto ao ator Rossi, que se houvesse com maravilhosa habilidade em muitos lances de elevada ordem dramática, é inegável; mas é também certa que não apresentou uma personificação completa e perfeita do Othelo concebido por Shakspeare.

"Na cena, por exemplo, em que o ardiloso lago profere cautelosamente as primeiras, indefinidas e quase imperceptíveis insinuações implicando a infidelidade de Desdêmona, o espírito real, altivo e majestoso de Othelo não sente e nem pode sentir os raios ardentes que lhe atribui o ator. (...)

"Na segunda parte dessa cena, porém, quando o marido de Desdêmona se acha já rendido às tormentas do ciúme, o desempenho foi magnífico. Nada podia ser melhor do que o modo por que o ator recitou o grito de desespero, o mais belo trecho da peça, em que Othelo se despede dos prazeres, da pompa e da glória da posição que tinha conquistado.

"Podíamos apontar outros senões a belezas, porém limitamo-nos a censurar o estilo exagerado que leva os atores a mostrarem fogo onde mais convinha a calma. Estamos disposto a perdoar muito a uma companhia que no todo representa tão bem peças da ordem de Othelo, e desejamos fervorosamente que semelhantes espetáculos sirvam para melhorar o gosto do público e elevar a arte dramática do Rio de Janeiro."

Uma outra parcela de escritores esmerou-se em tecer comentários de apreciação crítica, em especial comparando Rossi à outra representante da 
tragédia italiana que aqui já aportara, Adelaide Ristori. Um exemplo é Ferreira de Araújo:

"Ristori uma grande artista; fazia-nos sonhar, despertava em nós sentimentos sobre-humanos, fazia-nos saltar o coração com violência desusada, ao lembrar o que era aquela gente mitológica, que sabia o segredo dos filtros e encantos, que trucidava os filhos e falava em verso. Rossi não é assim, não é como Ristori. Fala como nós falamos, e é de crer que aquilo que ele sente nós sentíssemos também, se tivéssemos nascido sob o sol ardente da África, se tivéssemos crescido ao som das batalhas e depois tivéssemos concentrado toda a nossa vida no amor de uma mulher.

"Ristori era o sonho da tragédia, Rossi é a realidade dela; Ristori declamava com suprema graça uma tragédia inteira; Rossi di-la como nós dizemos aos nossos amigos o que sentimos e pensamos; recita um poema de amor aos pés de uma mulher com tanta verdade e naturalidade, que nos parece que estamos lendo no fundo do coração daquele homem, uma por uma, todas as estrofes do inspirado canto." ${ }^{103}$

Talvez o crítico que melhor resuma a passagem de Rossi, e já a expectativa da vinda de Salvini, seja Machado de Assis, tecendo sua apreciação na mesma linha, e relembrando Ristori:

"Regozijemo-nos meu caro Salvador, com as delícias que uma boa fortuna depara os amantes do belo, trazendo às nossas terras os gênios sumos da arte universal. Da Itália nos veio há dois anos a Ristori; da Itália nos veio agora o Rossi. A natureza os fadou para traduzir na sua bela língua as grandes paixões de arte teatral, para dar movimento e ação às obras máximas que a imortalidade bafejou. Fora triste que nos deserdassem da glória de os ter aplaudido.

"Há talvez uma diferença entre eles; se o gênio de ambos é igualmente profundo, o de Rossi me parece mais vasto. Alguns dirão, talvez que, conquanto que não haja para nenhum deles fronteiras de escola, a Ristori parecia amar especialmente a arte clássica, ao passo que Rossi tem 
particular afeto à arte romântica. Decidem os competentes essas coisas, que não são para mim; decide-as tu, se valem a pena, escrevendo o artigo de despedida ao nosso hóspede.

"O que eu desejava, meu caro Salvador, sabes tu o que era? Eu desejava uma coisa impossível, um sonho imenso. Era vê-los aos dois, e não só eles, mas também esse outro, que a fama apregoa, e que os nossos irmãos do Prata estão ouvindo e vendo, era vê-los todos três juntos, a combaterem pela mesma causa e a colherem vitórias comuns. Imagina Othelo, Hamlet, Yago, Cordélia, Desdêmona, Lear, Shylock, todo o Shakspeare enfim: imagina Horácio, Camilla, Fedra, Mirra, Luiz XI, Frei Luis de Souza, Stuart, que sei eu? Imagina todos esses grandes caracteres evocados pelo três italianos no mesmo prazo; no mesmo tablado, perante nós! Quel rêve!"104

Já em 1879 a presença de Rossi era esperada com um misto de entusiasmo e melancolia, como revela a chamada seguinte:

"Ernesto Rossi era esperado em Lisboa, em fins de fevereiro e daí partiria para esta capital, depois de pequena demora. Seja bem-vindo o grande trágico que nos vem fazer assistir a espetáculos decentes”. ${ }^{105}$

Após alguns anos da presença dos italianos nos palcos cariocas, as apreciações de Rossi costumam ser mais contidas, ainda que no geral elogiosas:

"Não repetiremos o que, a nosso ver, é Rossi no Othelo. Por mais que haja rareado o campo, ainda nele se apresentam competidores: Rossi e Salvini lutaram no mesmo terreno, aqui aos nossos olhos, e variaram os juízos. Cada qual formou o seu, nesse mesmo alguns vacilaram anteontem, ao passo que outros se confirmaram nela. Não esqueçamos, porém, que Rossi não é só grande na tragédia; o seu talento amolda-se a todos os gêneros, e é aí que está o seu maior mérito artístico."106

\footnotetext{
${ }^{103}$ O Guarany, ano I, no. 19, 21/05/1871, p. 7.

${ }^{104}$ A Reforma, 20/07/1871, p. 2.

${ }^{105}$ Seção Mista. O Echo Social, 13/03/1879, p. 4.

${ }^{106}$ Jornal do Comércio, 27/06/1879, p. 1.
} 
Ou, como afirma Saraiva:

"Ernesto Rossi é dos raros artistas deste tempo que tem o raro mérito da assimilação. Os seus personagens são inteiriços, e em nada revelam a personalidade do artista." ${ }^{107}$

Como podemos perceber, a passagem de Rossi pelo Brasil foi tema de numerosas discussões artísticas e estéticas, com polêmicas em jornais e argumentações de parte a parte. Otelo está na ordem do dia, e assim continuaria por um bom tempo, já que após Rossi várias outras encenações chegariam aos palcos cariocas. A primeira delas - muita aguardada - seria a de seu maior rival artístico, Tommaso Salvini, um modelo de interpretação até para Stanislavski.

TOMMASO SALVINI

"Otelo-Salvini era um monumento, um memorial que encarna certa lei universal."

Constantin Stanislavski

\begin{abstract}
"Não venham me dizer que os trabalhos de Shakespeare estão fora de moda, e que o público não os quer mais. Shakespeare é sempre novo - tão novo que ainda não foi compreendido por todos, e se, como dizem, o público não é mais atraído por suas peças, é porque elas são apresentadas superficialmente."
\end{abstract}

Tommaso Salvini

Tommaso Salvini nasceu em Milão em 01/01/1829, filho de atores. No entanto, até a adolescência não demonstrara interesse pela cena. Sua estréia ocorreu em substituição de última hora para um ator doente. A recepção calorosa do público o incentiva à carreira artística. O pai, então, o envia como iniciante a Gustavo Modena, que logo viu nele um grande talento. Alto, robusto e de belos

${ }^{107}$ Gazeta de Notícias, 27/06/1879, p. 1. 
traços, a figura de Salvini, mesmo tão novo, era imponente. Pai e filho trabalham juntos na companhia de Modena até que Tommaso fica órfão, aos quinze anos. Pouco depois, abandona a companhia e é contratado pela Compagnia Reale dei Fiorentini di Napoli. Atinge seus primeiros sucessos na Compagnia Domeniconi e Coltellini em 1847. Aos dezenove anos, o público e a crítica já o consagram como ator trágico no papel de Orestes, tendo Adelaide Ristori a seu lado como Electra e o próprio Domeniconi como Egisto. Seu grande trunfo, ao lado dos dotes físicos, é a voz, cheia de nuances e modulações. Seu ponto fraco, ao menos no início da carreira, é a memorização das falas, que the toma muito tempo.

Como Rossi, Salvini estreara no papel de Otelo, com a tradução de Carcano, em 1856, após passar um ano fora dos palcos voluntariamente para estudar a fundo três papéis, inclusive o do mouro de Veneza. Nas palavras de Carlson,

\begin{abstract}
"Ele ofereceu a peça pela primeira vez em um benefício em Vicenza em junho de 1856, pouco depois das produções shakespearianas de Rossi em Milão. O público não foi entusiástico, mas ao menos aceitou o trabalho com certo aplauso e, com este modesto encorajamento, Salvini ofereceu novamente a peça em benefícios em Veneza e Roma. Houve algumas reclamações relativas à sua irregularidade de tom e forma, mas Salvini era popular o suficiente para chamar multidões mesmo em papéis pouco convencionais. Othello foi sendo gradualmente aceito, e após algumas temporadas mesmo pedido". ${ }^{108}$
\end{abstract}

$\mathrm{Na}$ verdade, a demanda por Salvini-Otelo parece ter sido bastante poderosa, e perduraria por toda a carreira do ator, a tal ponto que ele mesmo exclamaria:

"Não sei se devo felicitar-me por haver encarnado aquele filho da
Mauritânia. O certo é que ele até certo ponto injustiçou as outras
personificações não menos elaboradas do meu repertório. Devo confessá-
lo; mas o Hamlet, o Orestes, o Saul, o Rei Lear, não me custaram menor
estudo nem menor dedicação; nem a minha consciência artística duvidou
jamais se haveria uma menor dose de mérito na interpretação desses 
personagens. Mas não: Otelo era o preferido, Otelo era o mais aclamado, Otelo era um débito que o público pagava exatamente, todas as vezes em que era apresentado". ${ }^{109}$

O convite para que viesse à América do Sul foi feito pelo empresário argentino Pestalardo, e Salvini decidiu-se a montar uma companhia para este fim. $\mathrm{Na}$ viagem, o próprio Salvini conta que encontrou um modelo para seu Otelo, em uma parada em Gibraltar:

"Em Gibraltar gastei meu tempo estudando os mouros. Fiquei admirado com uma excelente figura, majestosa no andar, e romana de rosto, exceto por uma pequena projeção de seu lábio inferior. A cor do homem era algo entre o bronze e o café, não muito escuro, e ele tinha bigode e um pouco de barba no queixo. Até aquele momento eu tinha sempre feito Otelo simplesmente com meu bigode, mas após ver aquele mouro soberbo passei a usar barba também, e tentei copiar seus gestos, movimentos e andar. Se eu pudesse teria imitado também sua voz, tanto aquele mouro esplêndido representou para mim o tipo verdadeiro do herói shakespeariano." 110

Salvini também narra sua chegada ao Rio de Janeiro:

"De Buenos Aires fui ao Rio de Janeiro, onde fiquei desapontado por não encontrar o Imperador Dom Pedro, que estava viajando na Europa. Mesmo assim, a Princesa Regente, filha do Imperador, não perdeu nenhuma noite em nosso teatro, e na noite de meu benefício ela me chamou a seu camarote, e me presenteou com um belo solitário, que me foi dado por seu consorte, o Conde d'Eu. Ela me honrou com um convite ao palácio imperial, e foi muitíssimo amável comigo."111

\footnotetext{
${ }^{108}$ CARLSON, Marvin. Op. Cit., p. 22

109 citado em SALVINI, Celso. Tommaso Salvini nella Storia del Teatro Italiano e nella Vita del Suo Tempo. Rocca San Casciano, Cappelli, 1955.

110 SALVINI, Tommaso. "Leaves from the Autobiography of Salvini", in The Century Illustrated Monthly Magazine, vol. XLVI, \# 5/6, September/October, 1893, pp. 779-780.

${ }^{111}$ Id. Ibid., p. 782.
} 
No Brasil, sua presença em 1871, após representar em Montevidéu e Buenos Aires, foi muito aguardada e festejada. Muitos críticos lhe favoreceram em relação a Rossi, entre eles Joaquim Nabuco. A estréia de Otelo ocorreu em 26 de setembro, e seria seguida por Hamlet em 06 de outubro.

O Jornal do Comércio ressalta a naturalidade de seus movimentos e a sua dicção, e afirma:

"Foi uma noite de verdadeiro frenesi entusiástico a de 26 do corrente, e para Salvini mais uma página gloriosa no seu álbum de artista-gênio. (...)

"Era na verdade comovente o ver-se o Mouro pairando entre a dúvida e a realidade, procurando abafar com surdos rugidos a dor que the oprime, roubando-Ihe a razão." ${ }^{112}$

Há, contudo, algumas críticas negativas, vindas especialmente dos admiradores do estilo de Rossi:

"O Sr. Salvini apoderou-se como artista, e não como gênio da interpretação da veemente tragédia.

"Os seus passos, os seus movimentos, as suas palavras são medidas pela regra, quando deviam ser de uma liberdade, de um revolucionário ímpeto, análogo a obra, ao sentimento, ao ideal do poeta. (...)

"Othelo é o terror e a doçura, é o amor e a cólera, por isso mesmo não sufoca a mulher amada senão no leito infamado, e não como o Sr. Salvini compreendeu, em plena cena, como um estrangulador vulgar.

"Os gestos de cavalheiro e de fera devem desde o primeiro ato ser revelados pelo mouro, a ponto de obrigar a imaginação do espectador a seguir os trâmites horrendos e selvagens do tremendo processo e da execrável pena. Por baixo da armadura do oficial veneziano, o espírito

${ }^{112}$ Jornal do Comércio, 28/09/1871, p. 3. 
público precisa seguir os constrangimentos ríspidos dos músculos da hiena indomável e insociável.

"Thomaz Salvini meteu o tipo no círculo de um estudo correto, profundo, inabalável. Eis quanto a nós o erro: nem Othelo é um tipo clássico, nem Othelo é um perfil humano, mas sim humanizado. Daí a fraqueza da moldura artística em que o grande trágico subjuga o esplêndido e incansável espírito do amante de Desdêmona. (...)

"Como trabalho artístico, o que nos apresentou Salvini no Othelo é obra de mestre, é um estudo merecedor de todos os sucessos da crítica imparcial. Como interpretação, não dizemos o mesmo: estuda-se, compulsa-se, mede-se o Orosmane de Voltaire, mas o Othelo de Shakespeare não se explica: revela-se." ${ }^{113}$

Na maioria dos casos, porém, quando da comparação entre Salvini e Rossi, os críticos tendem a exaltar as qualidades de ambos, sem esquecer de mencionar João Caetano:

\begin{abstract}
"A sala de S. Pedro de Alcântara que, há muitos anos, desde que se apagou o sol que iluminava aquele palco de tantas glórias passadas, não se enchia de um público digno do maior respeito, pela sua ilustração e apurado gosto, apresentou um aspecto majestoso na noite, em que o gênio italiano mostrou-se revestido do turbante do mouro de Veneza. (...)
\end{abstract}

"Sonharia, porém, o imortal inglês com artistas do merecimento de Rossi e de Salvini?

"A ninguém é dado adivinhar, e por isso só cabe aos admiradores curvarem-se diante da obra, e agradecer a Deus a dita de ver representar esses dois vultos, que deixam um nome imorredouro no cenáculo dos homens ilustres.

"Querer estabelecer semelhança entre essas duas celebridades é uma pretensão leviana e insólita, porque cada uma delas é grande, ou antes, é

${ }^{113}$ Diário do Rio de Janeiro, 29/09/1871, p. 2. 
maior, e a grandeza é uma e única. Rossi e Salvini, Salvini e Rossi são dois gêmeos do gênio, fundidos ao mesmo tempo, e pela mesma centelha acendida pela mão de Deus.

"Ambos estudaram Shakspeare, ambos interpretaram as suas obras, ambos compreenderam-no, ambos deram vida a esses tipos, que muitos outros têm assassinado no nascedouro.

"O mouro de Veneza é imenso com a alma de Rossi, é grandioso com o espírito de Salvini."

Salvini tornou-se notório na maior parte do mundo ocidental, especialmente nos Estados Unidos, onde iniciou uma tradição de apresentar-se com companhias locais, ele falando em italiano e os outros atores em inglês, o que não alterou seu êxito entre os americanos, antes pelo contrário. Chegou inclusive a contracenar com Edwin Booth, um dos grandes nomes do teatro americano do período, exatamente em Otelo.

Até por conta desse fato, a encenação de Salvini é uma das mais documentadas do período, sendo possível reconstruir quase que cena por cena os movimentos e entonações escolhidos pelo ator. Ajuda o fato de Salvini ter alterado seu papel muito pouco ao longo dos anos. Carlson faz um levantamento detalhado de cada passo, até chegar ao $5^{\circ}$ ato:

'Em 'inda o chora, mesmo em minha frente?' Salvini agarrava Desdêmona ajoelhada e a colocava em pé, e em suas primeiras apresentações nos Estados Unidos levantava-a e carregava-a uivando até o leito ( o New York Times afirmou que ele enfiou-a 'embaixo do braço como se ela fosse um guarda-chuva') Subsequentemente ele mudou esta ação para outra menos violenta, mas talvez mais cruel. Ele a pegava com uma mão e com a outra segurava seus cabelos e puxava sua cabeça para trás como se fosse quebrar seu pescoço, e então meio a carregava, meio a puxava, lutando e gritando, atravessando o palco até a alcova. Ela era morta atrás das cortinas, onde seus gritos e uivos misturavam-se aos gritos roucos

${ }^{114}$ Semana Ilustrada, ano 11, no. 564, 01/10/1871, p. 4510. 
animalescos, que indicavam com dolorosa clareza o que estava acontecendo.

"Apesar do realismo horrível da cena da morte, Salvini ficou ofendido com críticos que o consideravam 'bárbaro', 'passional', ou mesmo 'impulsivo'. Para ele era um ato considerado, inevitável, e mesmo heróico."115

O filho de Tommaso Salvini, o também ator Gustavo Salvini, viria posteriormente ao Brasil com sua própria companhia, em 1907, interpretando, entre outros, os papéis shakespearianos de Otelo, Hamlet, Rei Lear, e ainda Kean. Sua passagem pelo país não suscitou muito interesse, mas causou boa impressão, especialmente em Hamlet.

\section{ÁLVARO FILIPE FERREIRA}

O ator português e a companhia do Príncipe Real de Lisboa incluíram Othelo, o Mouro de Veneza no repertório da tournée feita ao Brasil em 1886. A peça estreou no Teatro de São Pedro em 29 de setembro, e o desempenho dos atores, se não foi empolgante, também não decepcionou.

O crítico P. Talma (Filinto de Almeida), de A Semana, assim se expressa:

"O desempenho, se na sua generalidade não esteve à altura da obra colossal do grande poeta inglês, foi, contudo, satisfatório, principalmente por parte de Álvaro (Othelo) e Costa (lago). Ora, quando nesta sublime peça não desagrada o desempenho destes dois papéis - está tudo salvo, porque os outros não têm importância notável. Álvaro foi muito feliz nas cenas violentas, mais do que nas de meditação e placidez. Foi bem representada a lenta invasão do ciúme naquela alma explosiva, e as imprecações do terceiro ato a lago foram ditas com suficiente calor. As cenas finais foram todas muito bem feitas, e notavelmente a última, desde o salto de tigre sobre lago até a degolação, que foi magnífica". ${ }^{116}$

\footnotetext{
${ }_{115}$ CARLSON, Marvin. The Italian Shakespearians. Washington, Folger Books, 1985, pp75-76.

116 Teatro. A Semana, ano 2, no. 92, 02/10/1886, p. 322.
} 
A apreciação do Jornal do Comércio chama a atenção para a tradução portuguesa da obra:

"A tradução da tragédia, que é do nosso compatriota José Antonio de Souza Freitas, maranhense, residente em Portugal há muitíssimos anos, é um primor como fidelidade e como estilo castiço português. Se a tragédia Othello é susceptível de ser traduzida, o que muito contestam, a tradução que anteontem ouvimos deve ser classificada entre as primeiras". ${ }^{117}$

Ambos os periódicos dão conta das qualidades de Álvaro e do ator Costa, este no papel de lago. Porém, a repercussão da encenação não parece ter sido intensa, especialmente em comparação com o grande ator português do período, Brazão, que também visitaria o Rio de Janeiro.

\section{GIOVANNI EMANUEL}

Nascido em Morano, em 11 de fevereiro de 1848, Emanuel abandonou os estudos e a expectativa de tornar-se advogado no primeiro ano da faculdade de estudos clássicos em Turim, por dificuldades financeiras do pai. Começou a trabalhar como escrivão, mas resolveu abraçar a carreira artística, mesmo sem acreditar que tivesse grande vocação.

O que sabia era que não concordava com o "convencionalismo" que via na cena italiana da época:

"Nem Gustavo Modena, nem Ernesto Rossi, nem Tommaso Salvini, os astros da cena do período, o satisfaziam por defeitos de natureza que ele encontrava na arte destes, ainda que alta e nobre. Não queria ter outro mestre que a si mesmo, ou, como ele próprio dizia mais modestamente, o Autor". ${ }^{18}$

\footnotetext{
${ }^{117}$ Gazetilha. Jornal do Comércio, 01/10/1886, p. 3.
} 
Dessa forma, seu estudo da personagem sempre era iniciado com uma profunda análise do texto. Emanuel costumava copiar à mão quatro ou cinco vezes o texto da personagem inteiro, depois o memorizava e aí começava a compor realmente a personagem; apenas quando estava absolutamente satisfeito com o resultado propunha-se a encenar a peça. Severo e nervoso na vida como em sua profissão, Emanuel notabilizou-se pela disciplina consigo e com sua companhia. Seu rigoroso método de preparação fez com que preparasse o papel de Kean, por exemplo, por doze anos antes de resolver montar a peça. Em suas próprias palavras:

\begin{abstract}
"A receita para aprender um papel é simplíssima. Ei-la: memorizar primeiro as falas, depois pensar a que classe social pertence o personagem, colocar dentro dele todo o seu coração e a sua mente, sentir a sua paixão como você mesmo a sentiria se estivesse na mesma situação, exercitar-se cinco, seis, sete vezes o papel pela manhã como você gostaria de representar à noite, e a criação está feita". ${ }^{119}$
\end{abstract}

Seguindo esse método, Emanuel estudou longamente as peças de Shakespeare, especialmente Otelo e Hamlet, discordando radicalmente da composição que Ernesto Rossi havia proposto para Otelo, marcada, segundo ele, pelo exagero. Os dois artistas, aliás, haviam se envolvido em uma longa polêmica a respeito do papel de Hamlet, em 1871, quando Emanuel trabalhava como crítico. Logo em seguida, ele abraçaria definitivamente a carreira artística, demonstrando no palco o que propusera nos jornais.

\begin{abstract}
"Distanciando-se de todos os outros intérpretes, Emanuel apresentou um Otelo natural e, por vezes, reconhecedor da inferioridade da sua raça. Tinha ímpetos e blandícias. Era admirável quando fazia Desdêmona conhecedora da ardente paixão que lhe inspirara; já presa da sua atormentada suspeita, conduziu todo o quarto ato de maneira a ser por vezes interrompido pela platéia, que o ovacionava, e impressionou sobremaneira na naturalidade com que morreu, na exata maneira por que deixou escapar o derradeiro alento. Vencida a primeira etapa dificílima, as
\end{abstract}

\footnotetext{
${ }^{118}$ LANCELLOTTI, Arturo, Op. Cit., p. 286.

${ }^{119}$ Apud LACELLOTTI, Arturo. Op. Cit., p. 289.
} 
representações que se seguiram redundaram em sucessivas vitórias para Emanuel". ${ }^{120}$

Lafaiete Silva está se referindo, especialmente, à encenação de Hamlet. Em sucessivas turnês, Emanuel interpretaria ainda Rei Lear, Romeu e Shylock, medindo forças com outros artistas no Rio de Janeiro em 1891, como Andrea Maggi e Ermetti Novelli.

Em relação ao papel de Otelo, o desejo de Emanuel era representá-lo de uma forma mais humanizada do que os outros artistas da época. Para isso, tomou para si a tarefa de traduzir a peça diretamente do inglês, apoiando-se ainda em todas as traduções italianas existentes até o momento. Queria um texto mais simples e fácil de falar em cena. Levou dois anos nesse processo, traduzindo e depois estudando a fundo a personagem. Os críticos do período tendem a concordar que Emanuel destacou-se como o Otelo mais humano e natural da cena italiana de então.

Emanuel representou pela Europa e também em vários países da América Latina, incluindo o Chile, o Peru e o México. No Brasil, esteve três vezes, em 1887, 1891 e 1896. Republicano, chegou a receber uma alta condecoração de D. Pedro II, afirmando depois que só a recebera porque era uma honraria à arte italiana e não a si. Em sua última passagem pelo Rio de Janeiro, já na época da república, seria prestigiado também pelo presidente.

Em 1887, as peças shakespearianas incluídas na tournée foram Othelo (estréia em 04/07) e Hamlet (14/07). Em sua segunda passagem, em 1891, o repertório contou com ambas (estreadas, respectivamente, em 13/06 e 29/06) e ainda com Rei Lear (a primeira a estrear, em 09/06), Romeu e Julieta (22/06) e $O$ Mercador de Veneza (29/07). Finalmente, em 1896 levaria novamente à cena Rei Lear (a partir de 10/06), Othelo (14/06), Hamlet (20/06) e O Mercador de Veneza (04/09). A recepção da crítica foi calorosa, assim como a do público carioca.

${ }^{120}$ SILVA, Lafaiete. Op. Cit., pp. 377-378. O autor não explica o que quer dizer com "reconhecer a inferioridade de sua raça". 
Entre os críticos, podemos destacar agora uma contenção e uma avaliação mais equilibrada do artista, sem a paixão que caracterizara a primeira vinda de Rossi e de Salvini, por exemplo, mas ainda assim entusiasmada:

"No elenco da companhia figura um nome, consagrado pela crítica e pelos aplausos, que atraía particularmente sobre si a curiosidade do público. Esse nome é o de Emanuel, para muitos o êmulo de Salvini e de Rossi, para outros o ofuscador das glórias dos dois célebres trágicos.

"Não afirmamos nem negamos que assim seja. O que podemos asseverar, o que anteontem vimos, é que Emanuel reúne em si todos os predicados do ator de primeiro plano: porte airoso e imponente, voz cheia, vibrante, maleável; gesticulação larga e distinta; corretíssimo no modo de ouvir e no modo de dizer; que sabe tirar todos os efeitos do olhar, que sabe traduzir na fisionomia o encontro das paixões do personagem que encarna em si; e que, finalmente, soube anteontem impor-se ao público, arrancando-o desse torpor com que geralmente assiste a uma estréia, subjugando-o, vencendo-o à força de arte e de talento, e fazendo sentir toda aquela tempestade de sentimentos opostos, de amor e de ciúme, que se desencadeia na alma do desventurado Mouro.

"O Othelo de Emanuel é um Othelo seu, que não se parece nem com o de Salvini nem com o de Rossi.

"Não é a fera que temos até hoje visto: é homem, homem desvairado pelo ciúme, mas que sente, que se comove e que comove.

"Não há uma frase, uma cena no seu papel, que não revele muito estudo, muito talento e completo conhecimento de todas as regras da arte dramática.

"Desde a exposição perante o senado de Veneza até a morte, no último ato, Emanuel foi verdadeiramente notável, assombroso, e conquistou uma das maiores ovações a que temos assistido em nossos teatros." ${ }^{121}$

${ }^{121}$ Gazeta de Notícias, 06/07/1887, p. 2. 
A Revista llustrada expressa o calor da recepção:

"E, no fim do espetáculo, uma verdadeira ovação foi feita a Emmanuel, que todos consideravam já um êmulo do Salvini e de Rossi, que, sem os fazer esquecer, em vários pontos parecia geralmente superior a essas duas imorredouras glórias da cena." ${ }^{122}$

O novo estilo de representação trazido por Emanuel, mais 'natural', é citado em inúmeras apreciações de seu trabalho, em geral de forma positiva:

"Emanuel é um revolucionário como todos os reformadores. Desprezando a antiga declamação, não se preocupando visivelmente do efeito que tinha de produzir, buscando a imitação da natureza, o talentoso ator teve de lutar anos inteiros contra a indiferença do público. Não desanimou, e hoje a sua reputação está firmada: Emanuel conquistou os foros de ator de primeiro plano." ${ }^{123}$

Ou, como se afirma em A Semana:

"O trabalho de Emanuel é mais do que um trabalho estupendo; é um trabalho novo, original e audaz. Vê-se bem que o principal desígnio do grande artista foi humanizar aquele Othelo que os precedentes intérpretes haviam tornado uma fera. Daquele tigre tradicional o imenso talento de Emanuel extraiu um homem. A nosso ver foi o primeiro artista italiano que compreendeu o naturalismo de Shakespeare. Parte daqui o seu admirável trabalho; todo ele é metodicamente deduzido deste princípio. Vislumbrando o enorme fundo de verdade que há naquele personagem, Emanuel preocupou-se com ser verdadeiro e conseguiu-o. Compreendendo que a verdade é a base de toda a arte, rompeu com todas as tradições, desprezou todas as academias, quebrou todas as regras, despedaçou todas as convenções, derrocou todos os ídolos consagrados - e foi verdadeiro." ${ }^{124}$

${ }^{122}$ Revista Ilustrada, ano 12, no. 460, 15/07/1887, p. 7.

123 Jornal do Comércio, 06/07/1887, p. 2.

${ }^{124}$ A Semana, ano 3, vol. 3, no. 132, 09/07/1887, p. 221. 
E, no Jornal do Comércio, que retoma a polêmica do estilo de Rossi e vê em Emanuel aquilo que os críticos de 1879 queriam, a naturalidade e a humanização da personagem:

\begin{abstract}
"Quando vejo um ator que, como Emanuel, reúne em si todas as qualidades de voz, figura, maneira de trajar, elegância, expressão, sem contar um conhecimento profundo da sua arte e sua competência artística inexcedível; eu julgaria um crime tentar amesquinhá-lo, procurando descobrir um lado por onde ele fosse vulnerável e querendo a todo transe achar-Ihe um defeito, para mostrar que a perfeição não é deste mundo. Inclino-me diante desse homem que considero superior aos mais e encho o meu ser de tanto entusiasmo e admiração, e elevo-o a uma altura tal que, ao olhar para mim mesmo, vejo-me tão pequeno ao lado dele que seria ridículo querer criticá-lo." ${ }^{125}$
\end{abstract}

A crítica do Jornal do Comércio de 1891 evidencia a diferença entre o estilo de Emanuel e seus predecessores:

"No difićlimo papel do Mouro de Veneza tem Giovanni Emanuel a mais franca, a mais positiva confirmação do seu gênio artístico; por ser um papel inquestionavelmente trágico, tem Emanuel, na sua interpretação ingente luta, da qual sai altivo e vencedor, graças à sua genial organização artística.

"Desprezando as fórmulas convencionais da tragédia, que parecem ser indispensável recurso para o seu bom êxito, Emanuel, filiando-se, tanto quanto the é possível a sua escola, consegue agradar e impressionar, nas cenas mais patéticas, principalmente; se não comove os espectadores pelas explosões trágicas, consegue dominá-los e arrancar-lhes até lágrimas pelas expressões as mais puras, as mais reais do sentimento humano e pelo modo por que as diz.

${ }^{125}$ Jornal do Comércio, 15/07/1887, p. 1. 
"O espectador fica surpreendido com a bela interpretação que o grande artista dá ao Mouro de Veneza, embora se afaste dos princípios trágicos em que eram soberbos Rossi e Salvini!"126

Em 1896, o Jornal do Comércio ressalta a predileção do público por Othelo e resume o sentimento deixado por Emanuel em suas três passagens pelos palcos cariocas:

"Othelo há de ser sempre a peça do grande poeta inglês preferida pelo público. Sua ação, sua urdidura, seus processos, seus desenlace, conservaram uma frescura que não diminui, uma atualidade que não passa. A gente que vai ao teatro, em geral, não compreende as sutilezas de Hamleto; o desespero de Lear, que passa dos salões do palácio real a vagar na solidão das florestas; a usura de Schailock, exigindo em pagamento de uma dívida a carne de seu devedor, mas todo o mundo compreende perfeitamente o tipo do mouro leal, crédulo, amoroso, arrebatado, em cuja alma o gênio satânico de Yago inocula o vírus do ciúme. Em todos os tempos hão de parecer singelos os meios empregados pelo grande poeta no desenvolvimento da sua primorosa tragédia. Se não fosse o caráter lendário do protagonista e a antigüidade da época, Othelo seria representado hoje como uma peça moderna com o desenvolvimento de sua ação tão humana em torno da figura de Yago, admiravelmente desenhada.

"É por isso que o público fez de Othelo a sua tragédia predileta, e ainda anteontem a concorrência ao Apollo foi maior do que na noite da estréia da companhia Italiana.

"Dizer o que foi o magnífico trabalho de Emanuel seria repetir o que por duas vezes, em 1886 e 1891, já disse esta folha e quase toda a imprensa fluminense sobre o mérito do grande artista, que conserva vivas as mesmas qualidades extraordinárias que levantaram então o nosso entusiasmo"127.

\footnotetext{
${ }^{126}$ Teatros. Jornal do Comércio, 15/06/1891, p. 2.

${ }^{127}$ Teatros e Música. Jornal do Comércio, 16/06/1896, p. 2.
} 
Mais além vai Olavo Bilac, ao afirmar:

"Por mim, creio que, na idade moderna, Shakespeare achou o seu melhor intérprete. Não sei o que se fez antes de Emanuel, porque não conheci Salvini, nem Rossi; mas pelo que deles escrevem os admiradores fiéis, compreendo que procuravam guindar-se às "proporções épicas" dos heróis, e que não tinham a sobriedade de Emanuel, - sobriedade que é a própria essência da arte pura. Depois dele, creio que se não achará interpretação nova: foi ele quem reduziu a homens os monstros da Tragédia, e o que agora há a fazer é apenas aplicar, com variantes da forma, a idéia básica deste processo....128

Temos, pois, com Emanuel, mais um estilo de interpretação, e ainda uma outra versão distinta do mouro de Veneza, em relação a seus predecessores. Cada vez mais, o modo de interpretar tragédias aproxima-se do drama, do 'humano'. É um processo da história da interpretação que se dá em um nível bastante amplo, e do qual Otelo é apenas um exemplo - mas um exemplo visto e comentado pelas platéias e pela imprensa carioca da época.

\section{EDUARDO BRAZÃO}

O grande ator português incluiu peças shakespearianas em duas de suas tournées pelo Brasil. Em 1887, encenou Hamlet, que estreou em 07/07, e Othello (28/07). Em 1893, traria Hamlet novamente (30/06). Brazão também encenou Kean nos palcos cariocas em 1887, provando a permanência da obra de Dumas no repertório das grandes companhias.

Se, por em lado, suas passagens pelo Rio de Janeiro parecem ter sempre sido celebradas com furor, por outro podemos perceber que Brazão sofreu com a comparação com Emanuel, quando ambos representaram Othello ao mesmo tempo. As críticas relativas à estréia de Othello, em diferentes periódicos, ressaltam o entusiasmo do público, e a celebração do ator, com festa após a

\footnotetext{
${ }^{128}$ Gazeta de Notícias, 20/06/1896, p. 1.
} 
apresentação, merece tantos comentários quanto a performance em $\mathrm{si}^{*}$. $\mathrm{Na}$ verdade, o encanto com a pessoa do artista se distingue, nos artigos de jornal, de algumas ressalvas feitas a seu trabalho em cena, ao que parece alterado pela comoção de estréia e da celebração:

\begin{abstract}
"O ilustre ator escolheu o Othelo para seu benefício e o representou aqui pela primeira vez. Não se pode falar com inteira justiça do desempenho que Brazão dá ao difícil papel do Mouro por vê-lo em uma noite como a de ontem, em que o seu espírito se achava abalado por tantas e tão desencontradas emoções. É preciso levar em linha de conta esse abalo, e pôr de lado qualquer idéia preconcebida sobre o tipo representado para dizer da interpretação que the foi dada ontem. Brazão dá-nos o Othelo selvagem como as suas paixões, impetuoso como o seu ódio, feroz como o seu ciúme. Não sabe dissimular, não sabe fingir. Crédulo, o ingênuo recebe a calúnia com a mesma facilidade com que explode em ira". ${ }^{129}$
\end{abstract}

Comparando a performance de Brazão em dois papéis shakespearianos, encontramos, no Jornal do Comércio:

"No Othello, Brazão é sempre grandioso, sempre correto, mas não apresenta aquela infinidade de pormenores que enriquecem a sua interpretação de príncipe dinamarquês. Mas não era saber, anteontem, se Brazão se vencia a si mesmo ou se era por si próprio vencido; o que anteontem se pretendia era fazer uma manifestação entusiástica, digna do grande artista português e a realidade excedeu todas as expectativas. A sala inteiramente cheia e composta do melhor da colônia portuguesa e da sociedade fluminense, ramos de flores atirados a todo o momento dos camarotes e da platéia, uma chuva de ouro e flores, das bambolinas, muitos pombos, poesias e no camarim, grande cópia de presentes de gosto e de custo, provaram eloqüentemente quantos admiradores entusiásticos tem Eduardo Brazão que foi chamado centenares de vezes e depois acompanhado até à sua residência por grande número de carros com lanternas e fogos de bengala". ${ }^{130}$

\footnotetext{
* Uma lista dos presentes oferecidos ao ator é incluída em pelo menos duas publicações, Novidades e Gazeta de Notícias (vide Anexos), e dá uma idéia da notoriedade do artista.

${ }^{129}$ Correio dos Teatros, Novidades, 29/07/1887, p. 2

${ }^{130}$ Jornal do Comércio, 30/07/1887, p. 1.
} 
A Gazeta de Notícias também segue a mesma linha crítica:

"É certo que, relativamente às exigências shakespearianas, talvez se pudesse exigir um colorido mais vigoroso, uma acentuação mais forte no caráter do mouro; mas também é verdade que para quem começa agora a lutar com as dificuldades do que se chama grande repertório o trabalho de E. Brazão é muito digno de aplausos e prova que o seu talento adapta-se facilmente às grandes criações teatrais.

"O que the falta para a extrema correção é muito pouco, em comparação dos dotes que ele já revela tão acentuadamente". ${ }^{131}$

Outros periódicos não são tão favoráveis, ao ator, ao menos em relação ao seu desempenho em papéis trágicos. Como indica o ator português Santos, em artigo de 1885 impresso em A Semana em 1887:

"Aquele carneiro preto, como the chama o próprio Shakespeare, aquele doente que precisa ser estudado patologicamente, como aconselha o Francisco Hugo, não é para a nossa educação teatral nem para a nossa organização. Brazão não tem peito, nem gesto, nem olhares, nem garganta, nem pulmões para fazer o Othelo, nem o Hernani, nem o Ruy Blas. Devia fazer admiravelmente o Carlos V e o D. Cezar de Bazan. Pode desenganar-se e talvez seja um bem para a sua saúde. Ele bem o sabe e o público já lhe disse que nunca poderá fazer tragédia. Será sempre um primeiro ator de alta comédia, um gentleman, um duque, um diplomata, de uma apresentação distinta e digna: se quiser será o nosso Delaunay. Faça - Duque de Aleria, Por causa de uma carta, o Misantropo, de Molière, o Copo d'água de Serib. O Duque Job e todo o repertório de Alfredo de Musset, até que os autores portugueses Ihe escrevam peças originais em que possa brilhar o seu talento. (...) Repare bem o meu colega Brazão que não disse não ter estudado os papéis que citei com amor, nem mesmo que os não tivesse compreendido; disse apenas que não é aquele o seu gênero e que não tem fôlego para tanto." 132

${ }^{131}$ Gazeta de Notícias, 30/07/1887, p. 2.

132 “O Ator Brazão julgado pelo Ator Santos”. A Semana, ano III, vol. III, no. 136, 06/08/1887, p. 251 
No mesmo periódico, encontramos outra crítica no mesmo tom:

"Infelizmente - e com desgosto dizemos - Brazão não é ator para produzir o grandioso personagem de Shakespeare. Othelo é um papel de grandes linhas e de largo fôlego. Exige um ator de sólida musculatura e de amplos pulmões. Aquele desvario de paixão, aquela violência de temperamento, a própria natureza e a própria história do personagem reclamam condições físicas de que não dispõe o notável e brilhante ator português. Assim pois, o seu Othelo não podia deixar de ser um Othelo pequeno,m mesquinho, acanhado, sem as proporções que the traçou o gênio portentoso do Ésquilo inglês. Brazão, finíssimo e superior artista para a comédia moderna; natural, elegante, distinto e verdadeiro nos salões do grande mundo e da aristocracia francesa, entende que há duas verdades na arte, e representa a tragédia a declamar, enfaticamente, quase cantando; de modo que os personagens absolutamente humanos de Shakespeare parecem personagens de ópera lírica, tão falsos, tão convencionais, tão mentirosos ficam.

"Dizer que o notável e simpático ator segue caminho errado representando a tragédia, é rigoroso dever da crítica desapaixonada e sincera, pois que a um artista de talento, que tem vontade, que tem aspirações e que estuda, não se deve nunca negar a verdade, nem vacilar na manifestação franca $e$ singela da opinião." ${ }^{133}$

Ao mesmo tempo, A Semana derrama-se em elogios a Emanuel, o que aborrece outra parcela da crítica, que defende Brazão e exalta o fato dele representar em português. Como afirma outro periódico, Novidades:

"É preciso notar que, se o classifico [Brazão] de grande artista, não desconheço o que ainda Ihe falta para colocar-se ao lado de Rossi, de Salvini e deste inesperado e surpreendente Emanuel. Mas pelo amor de Deus abstraiamos a prodigiosa Itália, sempre que houvermos de criticar artistas dramáticos de outros países". ${ }^{134}$

\footnotetext{
${ }^{133}$ A Semana, ano III, vol. III, no. $136,06 / 08 / 1887$, pp. 252-253.

${ }^{134}$ Novidades, 07/07/1887, p. 1.
} 
Um ponto de absoluto consenso entre as publicações do período é o excelente desempenho do ator João Rosa no papel de lago. Todas as críticas se alongam na apreciação de seu trabalho, o que não costumamos ver em outras críticas a companhias estrangeiras, visto que o grande foco é sempre o ator principal. No caso de João Rosa, porém, o entusiasmo dos críticos é unânime:

"Falando do desempenho do Othelo, é preciso lançar no primeiro plano, à plena luz, aquele magistral lago que ontem aplaudimos. De João Rosa disse o nosso colega Arthur Azevedo que 'será o melhor de todos os lagos possíveis'. Subscrevemos inteiramente essa opinião.

"lago é um papel pelo menos igual ao de Othelo, é a hipocrisia ao serviço da vingança, é o talento entregue à baixeza. João Rosa interpreta-o magistralmente, é insinuante, é persuasivo, é perverso como o tipo o requer. Diz admiravelmente aquele assombroso monólogo do $2^{\circ}$ ato e é magnífico em toda a tragédia". ${ }^{135}$

No Jornal do Comércio:

"Ou porque se respeita a hierarquia que Shakespeare deu ao seu Othello, alçando-o para protagonista, ou porque tal papel, sobre ser altamente antipático, é extremamente difícil, ou, ainda porque ao mouro de Veneza esteja reservado, nos últimos atos, toda aquela monumental ação dramática, que é prodígio de força e de violência, o certo é que ainda não tínhamos visto, no Rio de Janeiro, um Yago, digno da extraordinária concepção de Shakespeare e por isso, anteontem, todas as atenção ficaram desviadas, nos primeiros atos, para João Rosa, o mais esplêndido Yago, que, na maneira por que anteontem se houve, mostrou, que mais do que um ator correto e de talento, é um artista, que marca um ponto luminoso, onde aparece". ${ }^{136}$

E na Gazeta de Notícias:

\footnotetext{
${ }^{135}$ Correio dos Teatros, Novidades, 29/07/1887, p. 2

136 Jornal do Comércio, 30/07/1887, p. 1.
} 
"João Rosa diz a sua parte com um grande relevo, e é da sua dicção corretíssima e da sua grande naturalidade que tira os maiores efeitos de um papel, que assim desempenhado ocupa na tragédia o plano que the pertence". ${ }^{137}$

A apreciação de João Rosa, porém, não chega a turvar a estrela de Brazão. Ignorando (?) a passagem do ator Álvaro Filipe Ferreira no ano anterior, Novidades chega a afirmar:

"A Brazão cabe esta glória: ele ter sido o primeiro ator que apresentou Shakespeare aos que falam português, e escolhendo o Othelo para o seu benefício e obtendo o triunfo que obteve ontem deve se sentir recompensado de todos os trabalhos, de todas as lutas, de todas as contrariedades que deve ter tido". ${ }^{138}$

\section{ANDREA MAGGI}

Intérprete mais popular do papel de Cyrano de Bergerac na Itália, em comparação com Novelli, Zacconi e Emanuel (que, insatisfeito com a própria criação, desistiu definitivamente do papel após apenas três apresentações), Andrea Maggi era conhecido por seu bom humor, seu físico imponente e uma voz potente e resistente, que the possibilitava fazer sessões duplas de peças como Otelo, Hamlet e Rei Lear em um mesmo dia.

Nascido em 1852 em Turim, Maggi teve uma educação esmerada e fez teatro amador ao mesmo tempo em que freqüentava a universidade. Por fim, apaixonado pelo palco, foge de casa para seguir a companhia de Bellotti Bon, logo tornando-se primeiro ator. Alguns anos mais tarde, funda sua própria companhia. Além de Cyrano, outros papéis que Ihe deram fama incluem Kean, Hamlet e Rei Lear.

\footnotetext{
${ }^{137}$ Gazeta de Notícias, 30/07/1887, p. 2.

${ }^{138}$ Correio dos Teatros, Novidades, 29/07/1887, p. 2
} 
Casado com a atriz Pia Marchi, conhecida como La Pia, Maggi foi outro dos atores italianos a fazer longas excursões, até a saúde começar a falhar (morreu em 1910). Esteve na França, na Rússia e na América do Sul, colhendo glórias por onde passou, mas também sendo constantemente vítima de azares, como incêndios nos teatros.

Em sua tournée ao Brasil em 1891, Maggi representou o papel de Otelo, com estréia no Rio de Janeiro em 04/05, e também as personagens Lear (13/05) e Hamlet (20/05). Sua temporada no Teatro Lírico chamou a atenção de alguns críticos, mas sem o entusiasmo das passagens anteriores de artistas italianos. A crítica está, agora, mais exigente:

"No papel de mouro de Veneza, o novo ator italiano não ostentou, pelo menos anteontem, nem as explosões aterradoras de Salvini, nem os murmúrios cismadores de Ernesto Rossi, nem a elegância e naturalidade de Giovanni Emanuel, nem mesmo as hipérboles de superfetação de Novelli; mas, em compensação desse louvável repúdio aos grandes modelos, desejávamos ver alguma coisa, da sua lavra e individualidade, que o justificasse; porque, enfim, o alinhavado papel de Othello nem sequer dá direito às letras grandes dos cartazes e programas!

"De mais a mais, nada ajudava o nosso artista. A voz metálica e vibrante parecia perder a sonoridade à flor dos lábios; a caracterização era má e desigual; primeiro, apareceu caboclo, depois, branco, enegrecido pelo comércio do carvão e, finalmente, negro retinto! Para completar o desastre de anteontem, Maggi trouxe, quase toda noite, o braço esquerdo dobrado e colado ao peito. Faltava só a chapa protetora, para supor aquele braço, a braços com a cirurgia!

"Mas todos estes senões não podem ser séqüito constante, de um artista que vem precedido de uma certa reputação. Adiemos, pois, o nosso juízo, sobre o primeiro vulto artístico da companhia italiana, que trabalha atualmente entre nós; juízo humilíssimo, mas sincero e de boa fé."139

${ }^{139}$ Jornal do Brasil, 06/05/1891, p. 2. 
A maior crítica ao ator é em relação a seus dotes vocais. Como explica o crítico do Jornal do Comércio:

"O novo intérprete do Mouro de Veneza, de que nos ocupamos, sem confronto, é ainda moço; tem uma bela estatura e arrogância de porte suficientes para a apresentação garbosa do tipo do Mouro. Não o auxilia muito o seu órgão vocal, que o torna por vezes monótono e leva-o mesmo em ocasiões indevidas ao uso da falsa rouquidão; além de que, ressentese algumas vezes de rouquidão natural." ${ }^{140}$

Mesmo assim, alcança o reconhecimento de parte da imprensa:

"O ator Maggi tem excelentes dotes para a cena. Figura elegante, boa fisionomia, excelentes olhos e dicção clara e correta. No Othelo revelounos que havia estudado o papel, segundo a tradição dos grandes artistas Salvini e Rossi, modificando-o; em pequenas minúcias e principalmente na grande cena da morte. $O$ que lhe notamos, e que para muitos não é defeito e para nós é um defeito de escola - é uma toada por demais enfática e transições bruscas nas modulações da voz, que nem sempre se justificam pela significação das frases que tem de dizer e pelas situações.

"Não é artista de mérito vulgar; mas não é um artista igual - tem altos e baixos." ${ }^{141}$

\section{ENRICO CUNEO}

O italiano Enrico Cuneo chegou ao Rio de Janeiro em agosto de 1894, trazendo em sua bagagem mais uma versão italiana de Otelo, além de outras obras de Shakespeare. Eis a reação do Jornal do Comércio à sua estréia como mouro de Veneza:

"O ator E. Cuneo, ainda moço, modesto, mas trabalhador e observador profundo, encarregou-se anteontem da parte de protagonista da tragédia

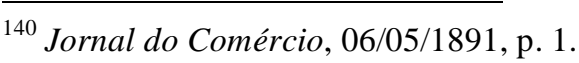


de Shakespeare, representada pela boa companhia Modena. Esse artista tem dado freqüentes provas da superioridade de seu talento aos poucos, mas sinceros devotos da Arte Dramática, que freqüentam o Teatro $\mathrm{S}$. Pedro; anteontem revelou novamente qualidades artísticas extraordinárias para a tragédia, já manifestadas no bom desempenho que deu ao Hamlet. Deu ao tipo do mouro boa expressão de naturalidade. Não foi de uma perfeição ideal em todo o seu longo trabalho, que oprime e fatiga o espectador; não mostrou a uniformidade irrepreensível que requer esse trabalho superior; mas subjugou a palidez de algumas cenas pelo vigor e colorido que deu a outras. Não entregou-se a transportes exagerados, quer na dicção quer na gesticulação. Nos dois primeiros atos mostrou a devida expressão fisionômica do mouro bondoso, inebriado pelo amor de Desdêmona. O seu rosto teve as naturais contrações de desespero nos diferentes transes por que passa o seu papel nos outros atos, desde que o honesto lago fere-o na alma com o veneno corrosivo do ciúme. Teve momentos felizes nas cenas de desespero pelo sofrimento atroz e nos de cólera pelas picadas venenosas do ciúme; onde, porém, seu trabalho conseguiu eletrizar o público, foi na cena final do seu suicídio por degolação, que foi colorida com toda a verdade. Basta essa cena para dar uma idéia do espírito profundamente observador do talentoso artista, que teve anteontem as mais entusiásticas demonstrações de apreço do público, infelizmente pouco numeroso, que assistiu à representação." ${ }^{142}$

O Correio da Tarde também aprecia seu trabalho:

\begin{abstract}
"Achamos o Sr. Cuneo muito melhor, nesta tragédia, do que no Romeu e Julieta; está mais no seu caráter artístico, no seu temperamento. No $2^{\circ}$ ato e na cena final do suicídio o Sr. Cuneo foi admiravelmente bem e colocouse a par dos mais importantes vultos do palco que nos têm visitado, pelo menos nas posições, na entonação da voz."
\end{abstract}

Além de Otelo, vale lembrar que Cuneo foi outro ator a representar o papel de Kean em sua temporada de 1894.

${ }^{141}$ Gazeta de Notícias, 06/05/1891, p. 1.

142 Jornal do Comércio, 27/08/1894, p. 1. 


\section{ERMETE NOVELLI}

O Otelo de Ermete Novelli (1851-1919) aporta ao Rio de Janeiro em 1895. Não era a primeira visita do ator ao Brasil; em 1890 já encenara Hamlet e outras peças. Mas na temporada de 1895, Novelli inclui quatro obras de Shakespeare: Hamlet novamente, O Mercador de Veneza - um grande sucesso na Itália, $A$ Megera Domada e, finalmente, Otelo, a última peça a estrear, em 26 de junho.

Tendo estreado nos palcos no pequeno papel de segundo comediante em Hamlet, em 1871, Novelli teve um início de carreira difícil, passando por várias companhias até chegar, em 1878, à Companhia de Bellotti Bon, que seria seu mestre por quase cinco anos. Depois, passa finalmente à Companhia Nacional, onde logo se torna o primeiro ator com a morte de Luigi Vestri.

Em 1886, monta a sua própria companhia. Notabilizado como artista cômico, identificado em especial com a obra de Goldoni, Novelli tenta persuadir o público de que possui também talento para os papéis trágicos. 0 reconhecimento não seria imediato, mas sua versatilidade acabaria se impondo e ele seria considerado um dos grandes Hamlets italianos do período, com uma proposta de interpretação simples e natural. Comunicativo e simpático, o ator sempre foi muito querido do público e dos colegas de profissão, apesar da rivalidade artística com Emanuel e, posteriormente, Zacconi (que viria finalmente ao Brasil em 1913).

Como artista, dava grande importância à caracterização da personagem, com o figurino, os adereços e especialmente a maquiagem. Um de seus grandes papéis seria Shylock, de O Mercador de Veneza, o qual

\footnotetext{
"Estudou meses e anos para obter uma figuração material e moral perfeita. Não contente em freqüentar por longo tempo a taberna de um hebreu veneziano, encontrou enfim em Trieste um outro israelita que, segundo ele, correspondia melhor ao tipo desejado. Este negociava cedro do Líbano, e
}

${ }^{143}$ Correio da Tarde, 27/08/1894, p. 2. 
o ator, para não se revelar, visitou-o várias vezes fazendo inúteis compras da madeira perfumada." 144

Novelli viajou por toda a Europa, chegando a Paris, contudo, apenas em 1898. Esteve também, além da América do Sul, no Egito e na Turquia.

No Brasil, a recepção de seu Otelo pela crítica foi mais positiva do que a de seus precedentes imediatos, Maggi e Cuneo, alcançando uma avaliação mais próxima à de Emanuel, ainda que sem a novidade do estilo deste:

"Novelli merece toda a adjetivação encomiástica do cronista teatral. Os seus trabalhos têm sempre um desempenho exatíssimo e muitas vezes extraordinário." 145

Contudo, o Jornal do Comércio pondera comparando Novelli a outros artistas, e especificamente a Emanuel:

"O nosso público, pouco curioso de conhecer novidades, como se o engenho humano se tivesse paralisado na impotência de produzir trabalhos de mérito, não resiste às tentações de um anúncio em que apareça o nome Shakspeare, e corra pressuroso ao teatro na ansiedade de comparar e de julgar entre Salvini, Rossi, Emmanuel e Novelli, os quatro gigantes do palco que têm assombrado com as fulgurações de seu gênio, quando reproduzem cenas violentas das paixões humanas no seu tumultuar desordenado de mar proceloso açoitado pelas borrascas. (...)

"Também prejudicou um pouco a tragédia a encenação do segundo quadro e a feição arqueológica dada por Novelli à figura de Othelo.

"Não se compreende a colocação daquele tribunal presidido pelo doge, que tem o seu trono no fundo da cena; ou Othelo teria de falar, sempre de costas para a platéia, e prejudicando muito a audição, ou então, como fez Novelli, tem de falar para o público dando as costas ao tribunal, o que

\footnotetext{
${ }^{144}$ LANCELLOTTI, Arturo. I Sovrani della Scena. Roma, Editrice Faro, s/d, pp. 356-357.

${ }^{145}$ A Semana, ano VI, tomo VI, no. 91, 29/06/1895, p. 173.
} 
produz uma impressão desagradável, fazendo sobressair a convenção do teatro, que é o que se procura sempre fazer esquecer no espectador.

"Estamos também mais de acordo com o processo de Emmanuel, trajando o protagonista de general veneziano; nem se compreende que Othelo comandasse as forças venezianas vestindo-se a seu bel-prazer de acordo com os costumes de sua raça. (...)

"Abstraindo-nos de comparações, achamos admirável a interpretação de Novelli, reduzindo os largos traços em que foi delineado o mouro de Veneza às proporções da mais estrita naturalidade; é um trabalho ingente, dificílimo, que só realizam os artistas superiores.

"Desde a narrativa até a cena final, o notável ator italiano desenha o personagem com uma harmonia de linhas, uma unidade de interpretação admirável. Toda a infinidade de pormenores de sua criação, de minudências diversas, harmonizam-se no tom geral, na homogeneidade da interpretação.

"Novelli foi aplaudidíssimo pela numerosa e seleta sociedade que enchia, anteontem, a vasta sala do Teatro Lírico, tendo tido muitos chamados à cena no final dos atos." ${ }^{146}$

Com tantas encenações ao longo dos últimos anos, os parâmetros tornam-se cada vez mais claros, e as opções artísticas dos atores e diretores de companhias naturalmente são mais questionadas. Mas, ainda assim, o trabalho de Novelli é admirado, como mostra a Gazeta de Notícias:

"O trabalho de Novelli começa a acentuar-se verdadeiramente no $3^{\circ}$ ato, quando a alma do mouro já está eivada das suspeitas e das sugestões de lago, o inimigo de todos e de tudo. Daí em diante, não há gradação da desconfiança, do ciúme, e do amor torturado por essas duas idéias, que o notável artista não acentue pelas entonações mais estranhas e mais variadas de sua voz, pelo jogo admirável da sua fisionomia, que, como um

${ }^{146}$ Jornal do Comércio, 28/06/1895, p. 2. 
espelho, reflete todas as ânsias, todas as dúvidas, todos os desfalecimentos e todas as iras da sua nobre alma de guerreiro.

"Mas, como se tudo isso ainda fosse pouco para o grande artista, ele reservou-nos para o final da peça uma verdadeira surpresa, a cena da morte, que ele reproduz com uma fidelidade minuciosa, cheia de pequenos detalhes, estrebuchando, agonizando, soltando verdadeiros roncos de agonizante, até rolar inerte pelo estrado do leito de Desdêmona.

"Como estamos em um período de crítica apurada, talvez até a impertinência, não sabemos se a cena da morte é discutível; mas o que é exato é que raramente vimos o público impressionar-se tão fortemente e tão largamente por uma cena desse gênero." 147

Após a temporada carioca, Novelli partiu para São Paulo, onde estreou com Otelo em 18/07, no Teatro São José. A temporada incluiria ainda, de Shakespeare, a Megera Domada (estréia em 25/07) e Hamlet (27/07). Diz a crítica de O Estado de São Paulo:

"O trabalho de Novelli no "Othello" foi extremamente elogiado pela unanimidade da imprensa do Rio. Achamos, porém, que o distinto artista, extraordinário na interpretação que deu aos outros papéis que aqui representou, não esteve na altura do seu incontestável talento.

"Parece-nos que a cena do $3^{\circ}$ ato, quando ele no célebre "addio" se despede dos seus amores, de suas glórias, com o coração despedaçado pelo ciúme, envenenado pela dúvida, que lhe invade a alma, usou na voz de extrema força, dizendo a frase com demasiada energia. Era natural que aquela frase exprimisse em toda a extensão a dor que amargura e que acabrunha. No último ato, porém, na cena da catástrofe sanguinolenta, Novelli foi aplaudidíssimo, tornando-se verdadeiramente assombroso pela veemência e brilhantismo com que representou as cenas finais da tragédia." 148

\footnotetext{
${ }^{147}$ Gazeta de Notícias, 28/06/1895, p. 2.

${ }^{148}$ O Estado de São Paulo, 20/07/1895, p. 2.
} 
A atriz Olga Giannini foi unanimemente reconhecida como uma Desdêmona graciosa, mimosa, por todos os periódicos. No geral, o ator Colonello, responsável pelo papel de lago, também agradou. A única nota dissonante vem do Jornal do Comércio:

"Sendo este o melhor papel do Sr. Colonello, é preciso confessar, ainda assim, que ele não chegou à altura do lago, o personagem mais inteligente desta tragédia, espírito forte, que faz horror aos hipócritas, aos escrupulosos e aos supersticiosos." ${ }^{149}$

${ }^{149}$ Teatros e Música. Jornal do Comércio, 28/06/1895, p. 2 


\subsection{6 - A ÓPERA ITALIANA E A CENA LÍRICA NACIONAL}

As relações entre Shakespeare e a ópera são intensas. Na verdade, há mais de 200 óperas compostas a partir de obras shakespearianas, desde The Fairy Queen (1692), de Henry Purcell, que se inspira em Sonho de uma Noite de Verão*. A maioria das obras, porém, é de uma qualidade artística não muito elevada, até pela dificuldade em adaptar os enredos de Shakespeare para música. Mesmo assim, compositores de vários períodos e nacionalidades lançaram-se a tal aventura, e temos óperas baseadas em peças shakespearianas compostas por Bellini, Berlioz, Holst e Zingarelli, entre outros. Isso sem contar um grande número de projetos abandonados pela metade, como um Macbeth de Beethoven, um Romeu e Julieta de Tchaikovsky, A Tempestade de Mendelssohn e vários Rei Lear, de Debussy, Puccini e Verdi.

Como nas adaptações para o próprio teatro, no caso das óperas a noção de fidelidade ao texto shakespeariano demorou a emergir, e mesmo assim com ressalvas, em parte devido à própria natureza do fenômeno operístico. Um exemplo simples, mas ilustrativo, é que a tradição da opera seria até o início do século XIX previa finais felizes, o que leva a diversos libretos que, apesar de baseados nas tragédias, fazem o protagonista sobreviver e até triunfar. Isso até uma das obras que nos interessam mais de perto, o Otello de G. Rossini, com libreto de F. Berio di Salsa. Como indica Rosen,

\footnotetext{
"O século XVIII requeria finais felizes. Um final trágico para uma opera seria não era muito aceito e é raramente encontrado. Mesmo no palco não musical, uma peça como o Rei Lear foi reescrita a fim de se salvar a vida de Cordélia. O advento da ópera séria romântica pode ser convenientemente datado a partir do Otello de Rossini, de 1816, em que o fim trágico é mantido, embora Desdêmona não seja asfixiada como na peça original, mas apunhalada. A estréia ocorreu em Nápoles, e conta-se que ela criou tal choque que, na segunda noite, certas pessoas da platéia gritavam pra Desdêmona assim que Otello aparecia - 'Cuidado, ele está com uma faca!' Mesmo que essa anedota seja apócrifa, sua veiculação
} 
reflete a mudança histórica. As boas maneiras e o decoro da opera seria do século XVIII haviam desaparecido. A violência, agora aceita na ópera séria, seria responsável pela nova rudeza de estilo musical, mas também pela imediatez e poder com que a música poderia ser utilizada para expressar sentimentos". 150

Ao longo do século XIX, a tragédia de Otelo inspirou duas obras interessantes: a de Rossini, já mencionada, e a de Giuseppe Verdi e Arrigo Boito. Ambas são marcos em seus momentos históricos e nas carreiras de seus compositores, e ambas conheceram encenações no Rio de Janeiro ao longo do período, configurando-se então como outras fontes de conhecimento, pelo público nacional, de Otelo e do enredo que o cerca. Por isso, é importante retomar os libretos de tais óperas e conhecer o que elas têm a dizer a mais sobre a personagem.

\footnotetext{
* As únicas obras do cânone shakespeariano que não foram musicadas foram algumas peças históricas, $O s$ Dois Cavalheiros de Verona e Titus Andrônicus.

${ }^{150}$ ROSEN, Charles. A Geração Romântica, edição revista e ampliada. São Paulo, EDUSP, 2000, p. 801.
} 


\section{O OTELLO DE ROSSINI}

"Eu a compus preso num quarto, contra a minha vontade, por um empresário careca e enlouquecido, que me trancou lá dentro só com um prato de macarrão e a promessa de que não me deixaria sair até que eu tivesse escrito a última nota dela."

G. Rossini

"They have been crucifying Othello into an opera." Lord Byron

"One factor alone contrives to redeem Otello, and that is our reminiscences of Shakespeare's Othello... we are so electrified by the magnificent musical quality... so spellbound, so overwhelmed by the incomparable beauty of the theme, that we invent our own libretto to match."

Stendhal

Apesar de elogiar a música de Otello, em seu $A$ Vida de Rossini - de resto um livro para ser lido com ressalvas, já que muito é inventado ou deduzido Stendhal desfia uma série de críticas à ópera, enumerando seus defeitos e explicando o que deveria ser alterado*. No entanto, a obra não deixou de ser um marco em seu tempo, e alteraria certos valores do fazer operístico da época.

Com estréia em Nápoles em 1816, Otello é a única ópera de Rossini (17921868) que se baseia em uma obra shakespeariana. A obra conheceu certo sucesso ao longo do século XIX, mas iria pouco a pouco caindo no esquecimento, especialmente após a estréia do Otello de Verdi e Boito, reconhecidamente muito superior tanto em termos de enredo quanto de cuidado musical. Contudo, se no caso verdiano o parentesco com a peça shakespeariana é evidente, como veremos em seguida, o mesmo não se aplica ao libreto - não muito bom, diga-se de passagem - do marquês Francesco

\footnotetext{
*Vide STENDHAL, A Vida de Rossini, seguido de Notas de um Diletante.São Paulo, Companhia das Letras, 1995, p. 189 e seguintes.
} 
Berio de Salsa, um colaborador apenas razoável do grande músico Rossini. De qualquer forma, devemos levar em consideração a afirmação de Schmidgall:

\begin{abstract}
"A ópera de Rossini, como as próprias peças de Shakespeare, são uma criação de seu tempo, espaço, e das circunstâncias de suas primeiras apresentações, e muito do que foi considerado 'sem sentido' (uma forma simples de dizer 'diferente de Shakespeare') fazia perfeito sentido nos bastidores do Teatro del Fondo em Nápoles no outono de 1816". ${ }^{151}$
\end{abstract}

No primeiro ato, passado no porto de Veneza, a cena se abre com a espera pela chegada de Otello após sua vitória contra os turcos. Suas glórias são comentadas (coro: Viva Otello, viva il Prode!) e o Doge vem recebê-lo. Otello dá ao Doge os troféus conseguidos (recitativo: Vincemmo, o padri!) e este the pergunta o que o general gostaria em troca de seus favores ao Estado veneziano. Otello explica que seu maior prêmio seria ser considerado, apesar de suas origens, um veneziano. lago e Rodrigo observam a cena e expõem seus sentimentos (Ah sì, per voi già sento). Rodrigo está desesperado, pois, por razões políticas, Elmiro, pai de Desdêmona, vai conceder sua filha em casamento a Otello. lago, que já começou a traçar seu plano, propõe ajudar Rodrigo. Este, mais tranqüilo, se retira com lago.

A cena se transfere para a casa de Elmiro, onde Emília e Desdêmona conversam. A jovem está preocupada por Otello, mas sua ama a conforta, afirmando que Otello já desembarcara bem e com todas as honras. Desdêmona explica que sua preocupação se deve a outro motivo: há algum tempo enviara uma carta de amor com um cacho de seus cabelos a Otello, mas acha que seu pai a interceptara. Não tendo escrito o nome do destinatário, Desdêmona teme que o pai pense que a carta era dirigida a Rodrigo e que Otello fique com ciúme. Emília a tranqüiliza (duo: Vorrei che il tuo pensiero). As mulheres se retiram com a chegada de lago e Rodrigo. Ficamos sabendo que a carta, na verdade, está nas mãos de lago, que explica um pouco de seu plano:

\footnotetext{
${ }^{151}$ SCHMIDGALL, Gary. Shakespeare and Opera. Oxford, Oxford University Press, 1990, p. 306. Uma das razões apontadas pelo autor para as mudanças do enredo seria a profusão de tenores de que o teatro dispunha naquele momento, que teria levado Berio e Rossini a investir no embate entre duas personagens
} 
por odiar o mouro, quer atiçar seu ciúme utilizando-se da carta sem destinatário. Ao mesmo tempo, Elmiro chega e afirma que mudou de opinião: por não gostar também de Otello,decidiu casar Desdêmona com Rodrigo, criando então uma aliança contra o mouro. Elmiro pede a lago que vá preparar a cerimônia sem demora, e este o faz. Satisfeito, Rodrigo parte em seguida. Ao encontrar a filha, Elmiro diz a ela que se prepare para uma grande alegria. A jovem, porém, fica em dúvida, e Emília também compartilha de sua incerteza.

No palácio do Doge, tudo está preparado para o casamento, festejado por vários venezianos (coro: Santo Imen! Te guida amore). Entram Rodrigo, Elmiro, Desdêmona e Emília, e só então a jovem é informada de que seu noivo é Rodrigo. Desdêmona recusa o enlace, o que enfurece tanto Rodrigo como Elmiro, que afirma que a castigará severamente se não aceder (terceto: $\mathrm{Nel}$ cor d'un padre amante). A chegada de Otello complica a situação; ele demanda a mão da jovem, visto que ambos se amam. Elmiro se nega a entregar a filha a Otello, que duela com Rodrigo. O ato termina em total confusão (L'ingrata, ahimè, che miro).

No segundo ato, em um jardim, Rodrigo tenta conversar com Desdêmona. Esta o repele afirmando que já é esposa de Otello. Tais palavras irritam o jovem, que jura que matará Otello e se retira. Emília chega e Desdêmona narra o acontecido a sua ama. Esta afirma que, se Elmiro ouvir o que Desdêmona dissera, uma desgraça poderá ocorrer. As mulheres se retiram preocupadas. Logo depois surge Otello, pensativo. Ele reflete que uma infidelidade de sua amada atentaria contra sua honra. lago surge, e vem conversar com o mouro, perguntando sobre o motivo de tantas preocupações. Eles conversam, com lago dando respostas oblíquas até afirmar a traição de Desdêmona. Otello hesita, e lago reage. Otello pergunta a lago se ele tem algum indício da infidelidade de sua amada. Aproveitando a deixa, lago entrega-lhe a carta roubada. Crendo que o destinatário é Rodrigo, a desespero do mouro surge. lago contempla a mudança de Otello com satisfação e mostra a ele a mecha de cabelo de Desdêmona que acompanhava a carta. Aqui, o ciúme de Otello 
aflora e ele jura matar sua esposa. lago tenta acalmá-lo, mas depois se compromete a ajudar Otello (duo: Non m'inganno). Alegre por seu plano ter tanto êxito, lago se retira. Rodrigo surge, e Otello, furioso, quer novamente lutar com o veneziano, que também não pode esperar o momento de ferir 0 oponente. Discutem e decidem duelar (duo: Ah, vieni nel tuo sangue). Desdêmona aparece e tenta dissuadi-los, mas não consegue. Ela fica sozinha, chorando, mas Emília e outras mulheres vêm consolá-la, informando-a de que Otello sobrevivera. O alívio da jovem não dura muito, pois seu pai, enfurecido, surge e a repudia. $O$ desespero de Desdêmona fecha o ato (ária: Che samnia, oimè! Che affano!).

No terceiro e último ato, Desdêmona, em seu quarto, fala de suas tristezas: Otello, que a crê infiel, fora exilado de Veneza pelo duelo, e seu pai a odeia. A canção de um gondoleiro (barcarola: Nessun maggior dolore), que retoma as famosas linhas do Inferno de Dante sobre Paolo e Francesca ("Nessun maggior dolore / che ricordarsi del tempo felice / nella miseria"), a deixa mais deprimida ainda, apesar do consolo de Emília. Melancolicamente, a jovem canta a canção do salgueiro ("Assisa a pie d'un salice") e lamenta seu destino. A ama se despede e se retira para que Desdêmona possa dormir. Porém, escondido de todos, Otello voltara a Veneza com o objetivo de vingar-se da amada. Ele entra no quarto, no momento em que uma tempestade começa. Ele hesita, mas crê que as palavras de amor que Desdêmona pronuncia em seu sono são dirigidas a Rodrigo (duo: Non arrestare il colpo). A moça acorda com um trovão e Otello a acusa, afirmando que lago conseguira por fim matar Rodrigo. Desdêmona jura inocência, afirmando que nunca amara o veneziano, mas Otello não acredita e a apunhala. $\mathrm{O}$ final da ópera é bem mais abrupto que o da peça. $\mathrm{Na}$ seqüência do crime, entram Lúcio, o Doge, Elmiro e Rodrigo, revelando que lago planejara tudo contra Otello e Desdêmona e que fora morto por uma punição divina. Rodrigo diz que renuncia a sua amada em favor de Otello, ficamos sabendo que o Senado também o perdoara, e Elmiro pergunta por sua filha. Ao entender o que ocorrera, Otello mostra o corpo da jovem e se mata. As ações se atropelam deliberadamente, para gerar um final fulminante. 
O final da ópera foi motivo de muita polêmica, já que apresenta uma grande inovação para a época. Normalmente, a opera seria do início do século XIX tinha um final feliz. Por isso, a censura e as autoridades eclesiásticas proibiram a estréia da ópera em Roma em 1820, o que forçou Rossini a escrever um novo final para sua obra. Nesta versão, Otello chega aos aposentos de Desdêmona decidido a matá-la, e diz-lhe que lago matara Rodrigo. A jovem reafirma seu amor ao mouro, o que aplaca seu ódio. Ambos cantam um dueto de amor, fazendo as pazes, e a seguir surgem as outras personagens, explicando tudo e celebrando o amor dos dois enamorados.

Não há muito a ser dito sobre a qualidade do libreto - ou a falta desta. Uma das suas maiores fraquezas, claramente, é o fato de, no segundo ato, Otello já entrar em cena refletindo sobre uma possível infidelidade que não havia sido mencionada antes, e que não faz sentido, fazendo com que ele seja o primeiro a levantar o tema junto a lago e não o contrário - mesmo assim, é forçoso reconhecer que o desenvolvimento da cena a partir daí reflete bem 0 movimento da cena shakespeariana. Há outras situações com um encadeamento lógico questionável. O castigo de lago e a renúncia de Rodrigo a seu amor não são convincentes, bem como a suspensão do exílio de Otello pelo Senado. O final feliz é ainda mais inverossímil, e, no entanto, foi amplamente utilizado, não apenas em Roma, mas em outras temporadas. Talvez porque, no mundo operístico, como afirmou Stendhal, a qualidade musical suplantesse os problemas.

Como podemos perceber, o enredo da ópera rossiniana bebe de várias fontes, shakespearianas ou não. Se por um lado os nomes das personagens, à exceção de Elmiro, derivam da peça inglesa, é apenas no terceiro ato que as referências ao texto de Shakespeare se avolumam. Como afirma Gossett,

\footnotetext{
"Se as personagens principais se chamassem Enrico, Zenobia e Ricciardo, poucos espectadores imaginariam que os dois primeiros atos tinham qualquer relação com a tragédia de Shakespeare. Teriam reconhecido, ao contrário, e com toda razão, certas situações típicas da ópera italiana da época: um casamento secreto entre um valoroso militar e uma mulher mais
} 
jovem; um pai que se opõe a esse casamento, pois escolheu outro esposo para a sua filha; uma confidente com gosto para intrigas; um duelo entre os rivais, a maldição do pai; e todo um arsenal de fórmulas melodramáticas familiares. É só no ato III, com a cena entre Desdêmona e Emília, a confrontação e a tragédia final, que a origem literária torna-se aparente. E, no entanto, esse libreto, apesar de uma lógica capenga que nem mesmo toda a boa-vontade do mundo pode ignorar, é incontestavelmente funcional, e, às vezes, até feliz". ${ }^{152}$

É o mesmo tipo de lógica que permeara a adaptação teatral de Ducis: um entrecho sentimental, com o papel de Rodrigo fortemente valorizado e o de lago diminuído; uma carta interceptada, sem destinatário; uma filha desobediente de um pai que surge várias vezes em cena, enfurecido; uma série de mal-entendidos, todos em Veneza, que levam a um desfecho trágico. É bom ressaltar que não há evidências de que Rossini ou Berio conhecessem o texto francês. O uso dos preceitos neoclássicos para aplacar as "ferocidades" de Shakespeare estavam difundidos em toda a Europa.

De Shakespeare, ainda é pinçada a idéia do exílio do amado da cidade após um duelo, presente em Romeu e Julieta. Outras referências a essa peça são elencadas por Schmidgall:

\begin{abstract}
"Na verdade, durante grande parte da ação do primeiro ato fica parecendo que Berio se inspirou em outra peça de Shakespeare: o pai de Desdêmona, Elmiro (=Capuleto) entrega-a (=Julieta) em matrimônio ao bem-relacionado Rodrigo (=Paris, filho do príncipe de Verona), e não a Otello, um potencial rival político (=Romeu)". ${ }^{153}$
\end{abstract}

Uma colcha de retalhos de referências, enfim, mas que conheceu certa fama e a preferência de não poucas cantoras, entre elas Isabel Colbrán, a criadora do papel, Maria Malibrán e Giuditta Pasta, já que, na era da ascensão da prima donna, o papel de Desdêmona também ganha em importância e dá margem a

\footnotetext{
${ }^{152}$ Apud COELHO, Lauro Machado. A Ópera Clássica Italiana. São Paulo, Perspectiva, 2003, pp. 339340.

${ }^{153}$ SCHMIDGALL, Gary. Op. Cit., p. 307.
} 
grandes interpretações*. Luque, que chama Desdêmona de "heroína shakespearianorossiniana", afirma que várias sopranos quiseram interpretar o papel. $^{154}$

É interessante perceber a diferença qualitativa existente entre o terceiro ato e os precedentes. Dean afirma:

"Otello é um divisor de águas, e não apenas porque é a primeira ópera italiana na qual os recitativos são acompanhados por toda a orquestra (...). Nos primeiros dois atos o libretista seguiu as convenções de sua época. (...) Mas ao chegar ao último ato, o libretista subitamente aderiu à peça, incluindo não apenas a Canção do Salgueiro e a cena que se segue, mas também o assassinato final. Isso foi uma inovação, e as pessoas ficaram tão chocadas que em algumas temporadas posteriores Rossini teve que fazer alterações. Mas o interessante é que a maior parte desse último ato é musicalmente de um nível muito superior ao resto da partitura. Algo da verdade dramática de Shakespeare parece ter penetrado em Rossini. Aqui, talvez pela primeira vez, podemos detectar a influência de Shakespeare em um grande compositor". ${ }^{155}$

A importância desse ato não deve ser subestimada, e já foi apontada por diferentes críticos, como ressalta Schmidgall:

\begin{abstract}
"Em seu estudo de Rossini, Francis Toye o chama [o terceiro ato de Otello] de 'uma obra-prima com apenas um defeito: a introdução do crescendo da canção da calúnia de // Barbieri, que efetivamente arruína o de outro modo magnífico vigor da cena entre Otello e Desdêmona quando ele vem matála.' Mais recentemente, o pré-eminente teórico rossiniano norte-
\end{abstract}

\footnotetext{
* Delacroix ficou tão impressionado com a versão operística de Rossini que suas pinturas trazem Desdêmona, e não Otello, como protagonista.

${ }^{154}$ LUQUE, Antonio Dominguez. "Um acercamento a la única obra shakespeariana de Rossini: Otello, o sia il Moro di Venezia", in Filomusica, Revista de Música Culta, revista mensual de publicación en Internet, número 68, septiembre 2005. (http://www.filomusica.com/filo68/otello.html, último acesso em 06/05/2007)

155 DEAN, Winton. "Shakespeare in the Opera House", in Shakespeare Survey no. 18. Cambridge, Cambridge University Press, 1965, p. 80.

* A utilização, por Rossini, de trechos de obras precedentes em novas óperas é comum, e ocorre em larga escala. Em Otello, encontramos ainda as aberturas de Turco in Italia e Sigismondo modificadas, e trechos de La Donna del Lago, Torvaldo e Dorliska e Ricciardo e Zoraide. Mas devemos destacar que tal
} 
americano, Philip Gossett, concluiu muito impressionantemente que 'se alguém tivesse que escolher apenas um momento como o divisor de águas entre os mundos da ópera italiana dos séculos XVIII e XIX, esse momento teria que ser o terceiro ato de Otello'. Rossini, ao que parece, aceitaria tão alto elogio. Quando Ihe perguntaram, no fim da vida, o que de sua obra sobreviveria, ele respondeu: 'O ultimo ato de Otello, o Segundo ato de [Guillaume] Tell e /l Barbieri di Siviglia'."156

Coelho também ressalta a evolução musical do terceiro ato, chegando à mesma conclusão que Gossett ${ }^{157}$. Na verdade, mesmo que Rossini se autodenominasse "o último dos clássicos", no ato final de Otello já há o prenúncio do Romantismo; é aí que ele inova e funda novas formas, como indicam críticos como Dahlhaus e Longyear. ${ }^{158}$

No Rio de Janeiro, as óperas de Rossini começaram a ser apresentadas em 1820. Otello, entretanto, demoraria mais. A obra conheceu algumas encenações entre 1847 e 1856, mesmo que, por vezes, apenas um trecho selecionado - basicamente, o famoso terceiro ato - fosse levado à cena. $A$ maioria das récitas se dá em parte de uma época de ouro, poderíamos dizer, do teatro lírico na corte. Como afirma Ayres de Andrade:

\begin{abstract}
"Em nenhuma outra fase de sua evolução no século XIX, conheceu o Rio de Janeiro um tal entusiasmo pelo espetáculo lírico, como nos anos que vão de 1853 a 1858. É bem o quadro de uma sociedade empolgada pela ópera e suas primadonas aquele que ali se define, conseqüência lógica e inevitável de um processo evolutivo. Este, partindo de 1844, vai alcançar o de 1853 engrossado e fortalecido por elementos eminentemente favoráveis que no caminho foi encontrando no meio social". 159
\end{abstract}

\footnotetext{
procedimento não é exclusivo de Rossini. Coelho chega a afirmar que se trata de um "hábito clássicobarroco". (Op. Cit., p. 46).

${ }^{156}$ SCHMIDGALL, Gary. Op. Cit., p. 310.

${ }^{157}$ COELHO, Lauro Machado. Op. Cit., pp. 342-343.

${ }^{158}$ Vide DAHLHAUS, Carl. La Musica Dell'Ottocento. Firenze, La Nuova Italia Editrice,1990, pp.59-70 e LONGYEAR, Rey M. Nineteenth-century Romanticism in Music. $3^{\text {rd }}$ ed. London, Prentice Hall, 1988, pp. 112-116.

${ }_{159}$ ANDRADE, Ayres de. Francisco Manuel da Silva e seu Tempo. Rio de Janeiro, Tempo Brasileiro, 1967, volume 2, p. 47.
} 
A primeira notícia de uma apresentação de Otello é de 1847. O terceiro ato "da ópera de Rossini Othelo ou o Mouro de Veneza"160 faz parte do programa de 10 de maio de 1847 em benefício de Filippe Tati, juntamente com trechos de outras óperas rossinianas, como Cenerentola e Semiramide, e de outros compositores. A estréia é comentada por Martins Pena em seu Folhetim de 18 de maio de 1847:

\begin{abstract}
"Deu fim ao espetáculo o terceiro ato de Otelo, desempenhado pelas Sras. Candiani e Meréa, e pelo Sr. Tati. A romanza foi bem cantada pela Sra. Candiani, e produziu geral sensação e prazer, que se traduziram em repetidos e longos aplausos. $O$ resto do ato é mais cena que canto, e Otelo e sua Desdêmona, o desempenharam satisfatoriamente. $O$ encarar com o Sr. Tati assim tisnado, com os olhos vidrados e luzentes, e com aquele sorrir de tigre e andar estacado, fazia arrepios; e, a falar a verdade, afligiunos vê-lo no escuro (isto só acontece no teatro) atrás da pobre moça, que não sabia onde esconder-se, até que, pilhando-a, mete-lhe a faca no pescoço, e a mesquinha exala o último suspiro dando a alma a Deus. Fêznos isto o efeito de uma cabra-cega infernal. Gostávamos mais (se nisto pode haver gosto) do modo por que o nosso Otelo dramático matava a Edelmonda. Ocorre-nos agora uma pergunta: se Desdêmona, logo que o Otelo-lírico apagou o facho, esconde-se debaixo da cama, iria este lá mesmo buscá-la no escuro às cabeçadas, ou escaparia ela por meio desse estratagema? Isto é uma interessante questão de vida e morte."161
\end{abstract}

Como podemos ver, o parâmetro otelino continua a ser João Caetano e sua versão de Ducis, mesmo estando o crítico aqui tratando do teatro lírico.

Em 1848 encontramos a primeira menção a uma encenação completa da ópera. Em 09 de fevereiro, encontramos o seguinte anúncio no Jornal do Comércio:

\footnotetext{
${ }^{160}$ Jornal do Comércio, 29/04/1847, p.4. O anúncio se repete na mesma página nas edições de 30/04, 04/05, 06/05, 08/05 e 10/05/1847. Como poderemos perceber, a grafia do título da ópera será alterada a cada representação posterior.

${ }^{161}$ MARTINS PENA. Folhetins - A Semana Lírica. Rio de Janeiro, MEC / INL, 1965, pp.235-236.
} 
"O benefício da irmandade do divino Espírito Santo da freguesia de Santa Rita ficou transferido para amanhã, 10 do corrente, em que irá à cena o seguinte espetáculo: apenas executada a ouverture do estilo, representarse-á a grande e sempre admirada tragédia Othelo ou O Africano de Veneza, de Rossini". 162

Mais definitivo é o anúncio publicado no Jornal do Comércio de 11 de fevereiro, referente, porém, a uma outra apresentação. Atentemos para o novo título dado à ópera, que se repete, e à descrição dos papéis principais:

\begin{abstract}
"Companhia Italiana - quarta-feira, 23 de fevereiro de 1848, benefício da prima dona Adelaide Tassini Mugnay. Primeira representação do drama trágico em três atos, belíssima composição musical do maestro Cavalheiro Rossini, intitulada Othelo ou O Africano de Veneza. Personagens: Othelo, africano ao serviço de Veneza - Sr. Tatti; Desdêmona, amante e esposa oculta de Othelo - a beneficiada; Elmiro, patrício Veneziano, pai de Desdêmona - Sr. Florillo; Rodrigo, filho do Doge, amante desprezado de Desdêmona - Sr. Mugnay; lago, inimigo oculto de Othelo - Sr. Sicuro $(\ldots)^{m 163}$
\end{abstract}

Outras referências a espetáculos em no mesmo ano apontam a expectativa da ópera completa em 16 de maio de 1848 - apresentação cancelada, contudo, por doença da Sra. Mugnay ${ }^{164}$, e o último ato em um espetáculo de 30 de junho de1848; contudo, Ayres de Andrade afirma que a obra foi apresentada por completo apenas uma vez em $1848^{165}$.

Em 1855 Otelo - com essa grafia - foi a ópera escolhida pela prima dona Mmle. La Grua para a sua estréia no Rio de Janeiro. Uma estréia muito comentada e aguardada, e que não decepcionou, como demonstra a crítica de José de Alencar, no Jornal do Comércio:

\footnotetext{
162 Jornal do Comércio, 09 e 10/02/1848, p. 4.

163 Jornal do Comércio, 11/02/1848, p. 4. Anúncio repetido nos dias 19/02, 20/02, 21/02, 22/02 e

23/02/1848, sempre na página 4.

${ }^{164}$ Jornal do Comércio, 16/05/1848, p. 4.

165 ANDRADE, Ayres de. Op. Cit., p. 16.
} 
"A noite da representação era esperada com ansiedade; e depois de Mme. Stoltz, nenhuma estréia tem causado tão grande expectação. Havia mesmo grandes prevenções, tinha-se excitado a curiosidade pública e exaltado a imaginação anunciando-se uma cantora de subido merecimento; o ensaio geral tinha concorrido poderosamente para esse efervescente entusiasmo.

Entretanto, semelhantes prevenções podiam fazer muito mal, e trazer uma decepção cruel. Seria necessário que Mlle. La Grua fosse um anjo descido do céu para magnetizar as almas secas e áridas, para regenerar os corações frios e impassíveis. E ainda assim talvez encontrasse algum desses espíritos contraditórios que se revoltam contra a opinião geral, e negam a verdade por que todos a confessam.

E Mlle. La Grua sabia disso tudo, e entrou em cena dominada por estas impressões desagradáveis. O receio muito natural se aumentara, e durante os primeiros momentos paralisara todos os seus recursos artísticos. A voz trêmula de emoção mal a podia soltar; estava como em um destes momentos solenes da vida, em que parece sentir-se pesar no ar sobre a cabeça a ameaça de um mal iminente.

Mas o receio esvaneceu-se pouco a pouco; a artista lutou, venceu a mulher e

\section{Was herself again.}

Foi como se deixasse cair o longo véu que cobria a bela estátua de Vênus de Fídias; revelou-se tal qual era.

O gesto animou-se, os olhos brilhantes, e a voz desprendeu-se ampla e sonora.

Os que a tinham ouvido no ensaio reconheceram-na, os outros renderam homenagens à artista simpática, à exímia cantora."166

166، Teatro Lírico”. Jornal do Comércio, 13/08/1855, p.1 
Ayres de Andrade aponta oito récitas da ópera com a soprano, que permaneceu no Brasil por um ano e meio e teve também em seu repertório Norma, Capuletos e Montéquios, Nabucodonosor, O Trovador, O Elixir de Amor, Horácios e Curiácios, Átila, Hernani, Dom Pascoal e Safo.

A mesma ópera seria ainda escolhida pelo tenor Tamberlick para a sua própria estréia no Brasil (onde permaneceria seis meses) em 26 de junho de 1856. Famoso mesmo na Europa, sua chegada em junho foi celebrada por José de Alencar:

"Com a chegada porém de Tamberlick e de Julienne Dejean é que a nossa cena se reanimará completamente; e que fará gosto assistir a uma dessas lutas do talento e da arte, lutas cujos troféus são as camélias, as rosas e os lindos ramos de flores que se abatem aos pés do vencedor.

"A vinda de Tamberlick é sobretudo muito necessária, não só por não termos um bom tenor, como por consideração para com as nossas patrícias. Na verdade é uma injustiça imperdoável que elas não tenham um cantor por quem se entusiasmem; entretanto que nós temos Emmy, Arsène e Annetta; nada menos do que três, isto é - um número suficiente para revolucionar o mundo". ${ }^{167}$

$\mathrm{Na}$ estréia, a primeira de suas três récitas como Otelo, ele não decepcionou a platéia carioca:

\footnotetext{
“Tamberlick! Tamberlick! Não se fala senão em Tamberlick: então que novidade é esta? (...) O Sr. Tamberlick cantou magistralmente o papel de Othelo, e mostrou-se a par da alta reputação que trouxe da Europa, e que conquistou nos primeiros teatros do mundo. Ator, ele sabe acompanhar com o gesto e com a intenção, que exprime em suaves harmonias; cantor, é intérprete fiel e inspirado dos pensamentos do maestro, cuja obra executa; artista na força da palavra, ele sente no coração os afetos que no canto revela..."168
}

${ }^{167}$ Apud ANDRADE, Ayres de. Op. Cit., p. 57. 
Alguns dias depois, encontramos, também no Jornal do Comércio:

"A escolha de Othelo para a estréia do Sr. Tamberlick, que a alguém pareceu - boa, a nós serviria imediatamente para consagrá-lo grande artista, se foi dele que partiu.

"De fato, qual é hoje o teatro na Europa que anuncia Othelo?... nem na própria Itália, onde nasceu essa sublime inspiração do famoso Rossini, ressuscita ele para encanto e delírio dos dillettanti.

"Mas por que se deixa no olvido uma obra monumental, um grande triunfo do gênio?... pergunta-lo aos empresários de todos os teatros, e eles vos responderão: 'Ah! São raros os Othelos, e quando com um se depara falta o Rodrigo, acha-se dificilmente o Yago, e sobretudo procura-se inutilmente a Desdêmona'.(...)

"A sua perfeita afinação, a maneira de estar em cena, o seu trajar à caráter, tudo enfim, faz do Sr. Tamberlick mais do que um cantor de mérito superior - incontestável, um artista completo em toda a extensão da palavra.

"Com tantas distintas qualidades, não quereria que o Sr. Tamberlick escolhesse Othelo, uma ópera de prova, uma admirável peça de toque para os artistas?"

Chama a atenção o comentário relativo às dificuldades em se encenar a ópera de Rossini, e parece que Tamberlick fez uma escolha feliz, que agradou à crítica como um todo. Ele continuaria tendo boa receptividade em outras óperas de seu repertório, que incluiu O Trovador, Os Mártires, Rainha de Chipre, Luísa Miller, Norma, Hernani, Lucrecia Bórgia, Maria Padilha, O Hebreu e O Juramento, além de Otelo.

168 “A Semana”. Jornal do Comércio, 29/06/1856, p. 1. 
Tamberlick fez muitas amizades no Rio de Janeiro, inclusive com João Caetano, a quem ia assistir sempre que não estava ele próprio no palco. 


\section{VERDI E BOITO}

"Instead of Otello being an Italian opera written in the style of Shakespear, Othello is a play written by Shakespear in the style of Italian opera."

G. B. Shaw

« De la même façon que le théâtre de Shakespeare est une projection du théâtre dans le théâtre, l'opéra de Verdi est une opéra " sur " l'opéra qui contient en lui-même sa propre réflexivité, mais une réflexivité destructive.

La meurtre de Desdemona et le suicide d'Otello, qui sont les conséquences de la machination diabolique de Jago, assurent le triomphe de l'intellect critique et négateur.

Le baryton parvient à empêcher le ténor et le soprano non seulement de s'unir, mais aussi, tout simplement, de chanter ; il les conduit plutôt à leur insu vers la parole, vers le silence, vers le rien. La dramaturgie d'Otello signerait ainsi la défaite du ténor. ”

Alain Patrick Olivier

O objetivo do comentário de Bernard Shaw, claro está, não era elogiar a ópera de Verdi, mas criticar a obra de Shakespeare. Porém, ele não deixa de assinalar a possibilidade de uma profunda relação possível entre a peça e uma ópera, que se traduziria no cuidado com que Giuseppe Verdi (1813-1901) e Arrigo Boito (1842-1918) adaptaram o texto, gerando uma nova obra de arte em si, independente, plena e notável.

Tanto Verdi quanto Boito já haviam tido experiências com Shakespeare - e depois de Otello ainda trabalhariam juntos novamente em Falstaff (1893), que fecharia o cânone verdiano com chave de ouro. Boito, um excelente poeta, antes de colaborar com Verdi já escrevera um ótimo libreto de Hamlet em 1865 (aos 23 anos de idade), musicado por Franco Faccio, que seria o regente da estréia de Otello. Nessa obra, já se podia perceber o esmero do autor ao tentar manter ao máximo as personagens e o enredo shakespeariano, ainda que com a condensação exigida pela forma operística. Quanto a Verdi, simplesmente o maior nome da ópera italiana da segunda metade do século XIX, seu Macbeth, de 1847 (revisado em 1865), marcara um ponto de mudança em sua carreira, 
em sua relação com a própria obra, e no cuidado com os detalhes e com 0 ensaio dos artistas. Como afirma Schmidgall,

\begin{abstract}
"Verdi, o mais shakespeariano de todos os compositores de ópera, também veio gradualmente a ter sua dexteridade em justapor modos ornados e simples de expressão. Muitos sugeriram, plausivelmente, que foi apenas com sua décima ópera, Macbeth, que ele veio a perceber suas criações como opere ad intenzioni, ou seja, óperas formadas de acordo com a convenção dramática e não com a musical. Com Macbeth, em outras palavras, ele começou a parar de pensar nas óperas como colares de cavatinas, duetos e coros um após o outro. Em busca dessas intenções teatrais mais aprofundadas, Verdi tornou-se com freqüência um partidário ferrenho da simplicidade. Ele abriu seu projeto de Macbeth com seu libretista, Francesco Maria Piave, com a exortação 'Brevidade e sublimidade'." 169
\end{abstract}

Já aqui Verdi demonstrava uma necessidade de interferir no libreto de suas óperas com fins dramáticos. E Francesco Maria Piave era muito flexível ao que o músico desejava. Em Macbeth, Verdi passou a preocupar-se mais também com a escolha dos cantores, que antes de tudo deveriam ser bons atores e adequados ao papel. Ele chegou a recusar Eugênia Tadollini como Lady Macbeth por sua voz ser "bonita demais". Preferiu Mariana Bambierinini, de timbre mais escuro, e chegou a levá-la a um hospital para que ela pudesse observar sonâmbulos.

No Rio de Janeiro, Macbeth estreou em 25/03/1852, inaugurando o Teatro Provisório, que passaria a se chamar Teatro Lírico Fluminense em 1854.

Por muitos anos, Verdi também acalentara um projeto de uma ópera sobre Rei Lear. Na década de 1850, o compositor chegou a trabalhar mais detidamente em um libreto sobre essa tragédia, preocupando-se particularmente com a execução de cada personagem dramaticamente*. Mas a ópera acabou não se concretizando.

\footnotetext{
${ }^{169}$ SCHMIDGALL, Gary. Op. Cit., pp. 61-62.

*Vide SCHMIDGALL, Gary, Op. Cit., p. 62 e seguintes.
} 
O projeto de Otello, carinhosamente apelidado pelo compositor de "projeto Cioccolatte" devido ao tom de pele do protagonista ${ }^{170}$, foi bastante longo. A ópera teve sua première no La Scala, em Milão, em 05 de fevereiro de 1887, mas Boito começara a trabalhar em seu libreto já em 1879. Com muito custo e a ajuda do editor Giulio Ricordi, Boito conseguiu convencer Verdi a musicá-lo. Verdi, que dava a sua carreira operística como encerrada após a composição de Aída (1871), foi se envolvendo cada vez mais com a idéia, que combinava seu amado Shakespeare com um de seus temas favoritos, o ciúme. Poucas vezes um compositor e um libretista fariam uma parceria tão afinada. O que foi feito por ambos para transformar a peça shakespeariana em uma ópera tão bem-sucedida?

Em Otello, Verdi resolveu brilhantemente a continuidade dramática construindo uma unidade musical em cada ato, gerando um fluxo narrativo constante (o que Rossini, aliás, também conseguira fazer no famoso terceiro ato de seu próprio Otello). Mas, além disso, os quase 3500 versos da peça se tornam menos de oitocentos na ópera. A compressão do enredo por Boito deixa de fora, obviamente, uma grande parte da obra de Shakespeare. Porém o cuidado com o qual isso se deu pode ser conferido ao examinarmos o libreto de perto. Por exemplo, são cortadas todas as cenas em Veneza - ou seja, o primeiro ato inteiro da peça. Mas de forma a não acarretar perda dramática, mas ganho:

\begin{abstract}
"Suprimindo o ato veneziano, Boito conseguiu uma vantagem dramática dupla; ele economizou tempo valioso para o desenvolvimento posterior do enredo, e iniciou a ópera em um clímax tremendo no qual o tumulto físico prepara o clima para a tempestade psicológica por vir, como se os elementos estivessem ligados às paixões humanas. Mas ele não ignorou o primeiro ato de Shakespeare; ao menos cinco de suas passagens estão presentes no libreto." 171
\end{abstract}

\footnotetext{
${ }^{170}$ VERDI, Giuseppe. Lettere 1835-1900. Milano, Arnoldo Mondadori Editore, 2000, p. 350.

${ }^{171}$ DEAN, Winton. “Verdi's 'Otello': a Shakespearian Masterpiece”, in Shakespeare Survey, Volume 21. Cambridge, CUP, 1968, p.89.
} 
Vejamos como se desenvolve o enredo da ópera em sua totalidade, para termos uma idéia mais clara de todas as transformações.

A ópera se inicia em meio a uma grande tempestade, enquanto uma multidão (que inclui Montano, Jago, Cássio e Roderigo, mas não Desdêmona e Emília) espera ansiosamente a chegada do navio de Otello no porto de Chipre. Este finalmente desembarca triunfante e narra o naufrágio da esquadra turca. Enquanto Otello é aclamado, Jago conversa com Roderigo (com elementos tirados do primeiro ato shakespeariano), consola-o de seu desespero por amar Desdêmona e explica seu próprio ódio pelo mouro por ter promovido Cássio e não ele. Seu plano é posto em prática imediatamente. A cena se liga a uma comemoração na qual Jago convence Cássio a beber à saúde de Otello, enquanto Roderigo espera uma oportunidade para provocá-lo. Sob o efeito da bebida, Cássio reage às provocações de Roderigo. Montano tenta acalmá-los, e acaba ferido pela espada de Cássio. Otello surge em meio à confusão, e intervém com autoridade.

José Carlos Ruiz Silva, que faz um extenso cotejamento entre os textos de Shakespeare e de Boito, exemplifica aqui a fidelidade do libretista às palavras da peça, apresentando os textos lado a lado:

"A cena culmina com o retorno de Otelo. Ato II, III, 162:

OTELLO: Olá! Che avien? Son io fra i Saraceni?

O la turchesca rabbia è in voi trasfusa.

E mais adiante:

OTELLO: Onesto lago.

Per quell'amor che tu mi porti, parla,

IAGO : Non so... quì tutti eran cortesi amici.

OTHELLO : Why, how now, ho ! from whence arises this?

Are we turn'd Turks, and to ourselves do

That which heaven has forbid the Ottomites? 
E mais adiante:

OTHELLO: Honest lago, that looks dead with grieving, Speak.

IAGO: I do not know, friends all but now, even now." ${ }^{172}$

Cássio é destituído de seu posto e todos se retiram, deixando Otello e Desdêmona sozinhos. Vemos então um outro lado de Otello, até aqui caracterizado apenas em sua glória militar. O dueto de amor retoma trechos explicativos da cena do Senado (primeiro ato da peça shakespeariana) e também do encontro dos enamorados em Chipre ${ }^{173}$. Os dois se beijam durante um tema musical que será retomado até a última cena da ópera.

O segundo ato se passa em um salão no castelo. Jago consola Cássio, garantindo que logo este reconquistará sua posição e sugerindo que ele peça a Desdêmona para interceder junto a Otello para conseguir seu perdão. Deixado a sós, Jago declama seu famoso Credo, falando de sua vilania.

“Credo in um Dio crudel che m'ha creato

simile a se, e che nell'ira io nomo.

Dalla viltà d'un germe o d'un atòmo

vile son nato.

Son scellerato

perché son uomo;

e sento il fango originario in me.

Sì! questa è la mia fè!

Credo con fermo cuor, siccome crede

la vedovella al tempio,

che il mal ch'io penso e che da me procede

per mio destino adempio.

Credo che il giusto è un istrion beffardo

172 SILVA, José Carlos Ruiz. "Shakespeare-Verdi: 'Otello'. Estúdio comparado del 'Othello' de Shakespeare y de su transformación en libretto de opera", in Anales y Bolétin de la R.A. de Bellas Artes de San Fernando. Madrid, 1976, p. 32. 
e nel viso e nel cuor,

che tutto è in lui bugiardo:

lagrima, bacio, sguardo,

sacrificio ed onor.

E credo l'uom gioco d'íniqua sorte

dal germe della culla

all verme dell'avel.

Vien dopo tanta irrision la Morte

E poi? La Morte è il Nulla

e vecchia fola il Ciel". ${ }^{174}$

Essa ária é motivo de muita polêmica entre os críticos. O quanto do lago shakespeariano estaria ali? Boito havia composto ele mesmo uma ópera sobre Fausto chamada Mefistófeles, que parece perpassar o trecho em questão. Kobbé coloca:

"Considerada uma obra-prima da invectiva, a passagem não deixa de configurar uma simplificação da personagem shakespeariana, em versos (e sentimentos) originais de Boito". ${ }^{175}$

Não era, porém, a opinião de Verdi:

$$
\begin{aligned}
& \text { "Belíssimo este Credo, potentíssimo e shakespeariano em tudo e por } \\
& \text { tudo". }{ }^{176}
\end{aligned}
$$

Voltando ao libreto, Jago observa Cássio conversando com Desdêmona no jardim e, vendo a aproximação de Otello, comenta que não gosta do que vê. Otello passa a interrogá-lo, como em Shakespeare, e Jago começa a instigar-

\footnotetext{
${ }^{173}$ Vide SILVA, José Carlos Ruiz. Op. Cit., pp. 32-33.

${ }^{174}$ VERDI, Giuseppe. Libretti. Milano, Arnoldo Mandadori Editore, 2000, pp. 341-342. A tradução literal do trecho seria "Creio em um Deus cruel que me criou / à sua imagem e que nomeio em ira. / Da vileza de um germe ou de um átomo / vil eu nasci. / Sou mau / porque sou homem / e sinto a lama original em mim. / Sim! Esta é a minha fé. / Creio com o coração seguro, como crê / a viuvinha no templo, / que o mal que eu penso e que vem de mim / é meu destino fazê-lo. / Creio que o homem honesto é um ator enganador / e no rosto e no coração / Creio que tudo nele é mentira / lágrima, beijo, olhar / sacrifício e honra. / E creio que o homem é joguete da sorte iníqua / do germe do berço / ao verme da tumba. / Vem depois de tanto engano a Morte. / E depois? A Morte é o Nada / o Céu é uma velha fábula."

${ }^{175}$ KOBBÉ, Gustave. O Livro Completo da Ópera. Trad. Clóvis Marques. Rio de Janeiro, Jorge Zahar Editor, 1997, p. 359.
} 
Ihe o ciúme. A evolução dramática e a intensidade crescente da música perpassam toda a cena. Há uma quebra com o madrigal, em que um grupo de camponeses traz a Desdêmona flores e jóias, uma cena que acalma Otello e suas suspeitas. Mas em seguida a jovem vem falar com 0 marido, acompanhada por Emília, e começa a pedir por Cássio. Otello a repele, com crescente irritação. Ele joga o lenço dela no chão com raiva; Emília o pega, mas Jago imediatamente toma posse do mesmo, discutindo com a mulher, com Otello e Desdêmona ainda em cena. É um quarteto notável, ou antes dois duetos superpostos, com um casal cantando e o outro em recitativo, que termina quando a jovem pede perdão a Otello se o ofendera, e este expressa suas dúvidas quanto ao amor dela. As mulheres se retiram, e Jago planeja colocar o lenço no quarto de Cássio.

A importância do quarteto é comentada por Dean:

"Um dos episódios mais significativos de qualquer ópera é o famoso quarteto no qual Desdêmona tenta aplacar as primeiras manifestações do ciúme de Otello enquanto Jago consegue seu lenço através de Emília. Aqui temos eventos e personagens em suas motivações, explícitas ou não, tudo desenvolvido simultaneamente com uma economia e uma multiplicação de ironia que não é possível em uma peça, onde não há orquestra e as personagens não podem falar todas ao mesmo tempo. Ao mesmo tempo, é um trecho musical de forma e beleza maravilhosas. Se você ler o libreto de Boito sem a música, você sente que muito da peça está faltando; mas é como ler uma sinopse em prosa da peça ao invés de assisti-la no teatro. A música de Verdi completa a conexão dramática, e dá um equivalente para a poesia. O resultado é uma grande ópera, que não é apenas misturar duas artes, nem mesmo comprometer uma com a outra; é uma nova experiência em si mesma, complexa e profunda" ${ }^{177}$

Otello, sozinho com Jago, expressa seu equivalente ao monólogo "Farewell" shakespeariano: Ora e per sempre addio. Irado, ele joga Jago no chão, ameaçando-o, e exige provas da infidelidade da esposa. Jago narra um

\footnotetext{
${ }^{176}$ VERDI, Giuseppe. Lettere. Milano, Arnoldo Mandadori Editore, 2000, p. 353.
} 
suposto sonho de Cássio com a jovem e afirma ter visto o mesmo carregando o lenço que Otello dera a Desdêmona no dia de suas núpcias. Otello jura vingarse ao comprovar a traição, e Jago aproveita para jurar também seu apoio ao mouro e a seu plano de vingança.

O terceiro ato se passa em um salão do palácio. Anuncia-se a chegada dos embaixadores de Veneza. Desdêmona, que não entende o estranho comportamento do marido, mais uma vez intervém pedindo por Cássio. Otello, por sua vez, insiste em ver o lenço de Desdêmona. Ele a maltrata, enraivecido, e ela foge. O mouro reflete, até que Jago vem dizer que Cássio se aproxima. Otello se esconde para ouvir a conversa entre Cássio e Jago, que ele crê ser sobre Desdêmona - na verdade é sobre Bianca, personagem que é citada mas não aparece em cena na ópera. Cássio mostra a Jago o lenço que encontrara em seu quarto, e retira-se ao ouvir os trompetes dos embaixadores. Enquanto estes são aclamados ao fundo pela multidão, Otello e Jago tramam a morte de Desdêmona no seu próprio leito.

Na seqüência, os embaixadores chamam Otello de volta a Veneza e nomeiam Cássio governador de Chipre. Transtornado, Otello atira a esposa ao chão na frente de todos, que tentam em vão pedir clemência por ela. Otello manda todos embora, e então desmaia. Ao fundo, o povo o aclama julgando que a volta a Veneza Ihe dará mais glórias, enquanto Jago contempla o poder de seu veneno funcionando.

O último ato mostra o quarto de Desdêmona. Esta conversa com Emília, pede para esta arrumar seu leito, e lhe dá um anel antes de separarem-se. A defesa da infidelidade, que Emília faz na peça de Shakespeare, é suprimida, mas a canção do salgueiro cantada por Desdêmona (Piangea cantando) permanece. A jovem reza, como na ópera de Rossini. Em seguida, Otello entra e, após hesitar, a beija três vezes. Ambos discutem a partir das acusações de Otello, e este acaba por assassinar a esposa, que até o fim insiste em sua inocência. $O$ final segue o enredo shakespeariano, mas é bastante comprimido; há a volta

${ }^{177}$ DEAN, Winton. "Shakespeare in the Opera House", in Shakespeare Survey no.18. Cambridge, CUP, 1968, p. 84. 
de Emília, dizendo que Cássio matara Roderigo, o alarde com a descoberta da morte de Desdêmona, a vinda à cena de Cássio, Jago, Lodovico e Montano, este com a confissão do moribundo Roderigo, mas Jago não apunhala Emília, e após a sua fuga do palco, não sabemos mais nada sobre seu destino. Otello compreende que fora enganado e se mata, voltando a música ao tema do beijo, que perpassa toda a ópera. É um final grandioso que reflete a tentativa final de Otello da recuperação de sua nobreza, presente no último monólogo da peça shakespeariana.

É preciso ressaltar que o cuidado na confecção da ópera foi um trabalho conjunto entre Boito e Verdi, como atesta farta documentação da época. $\mathrm{Na}$ correspondência entre os dois colaboradores, podemos ver o nível de detalhamento a que chegam os dois parceiros, às vezes discutindo palavra a palavra, como aponta Michel Orcel*. Verdi demonstra uma preocupação com o texto e com a composição de cada personagem, a tal ponto que é impossível dizer que ele simplesmente musicou um libreto de Boito; o texto foi verdadeiramente iniciado por Boito, mas lapidado exaustivamente a quatro mãos. Um bom exemplo é encontrado na carta de agosto de 1881:

"Caro Boito,

(...) Muito, muitíssimo bom o Final. Quanta diferença entre este e o primeiro!

Colocarei os quatro versos para Roderigo.

Talvez sejam inúteis os outros quatro para Desdêmona.

É tão verdade que Otello silencioso é maior e mais terrível, que eu opino que não devemos fazê-lo falar, na verdade, durante todo o trecho do conjunto. É melhor que só Jago fale, e mais brevemente, tudo aquilo que se deve dizer para a inteligência do espectador sem que Otello responda Jago - T'affretta! II tempo vola! All'opra ergi tua mira! All'opra sola! lo penso a Cassio... L'infame anima ria gli svellerò. Lo giuro. Tu avrai le sue novelle a mezzanotte (ajustando, entendem-se os versos)

Depois do coro e das palavras 'Tutti fuggite Otello', me parece que Otello não fala e clama o suficiente. Ele se cala por quatro versos e me parece

\footnotetext{
"Vide ORCEL Michel. "Lui, c'était Shakespeare", in VERDI, G. Otello, programa da temporada 20032004. Paris, Opéra Nacional de Paris, 2003, pp. 49-53.
} 
(cenicamente falando) que após 'Che d'ogni senso il priva' Otello deveria gritar um ou dois versos... Fuggite. lo detesto voi, me, il mondo intero...

$\mathrm{E}$ me parece também que se você pudesse economizar alguns versos quando restam apenas Otello e Jago em cena (...)

Ainda não acabei! O Coro age pouco, ou nada. Não se pode encontrar um meio de movê-lo um pouco? Por exemplo, depois das palavras... In Cipro elegge um successor... Cassio! Coro com quatro versos não digo de revolta mas de protesto... Nò Nò: Noi vogliamo Otello (...)". ${ }^{178}$

Na carta de 14 de maio de 1886 - cinco anos depois, portanto -, já com a definição de que Tamagno cantaria o papel de Otello, Verdi ainda propõe mudanças:

\section{" Caro Boito}

Estou felicíssimo por você haver conservado os três versos ... d'attorno un Jago.

Uma pequena coisa e já termino... Quer dizer, você termina! Você sabe que a tempestade (musicalmente falando) continua durante a entrada de Otello, e termina após o Coro (...). Há versos demais no solo de Otello, e a tempestade fica muito interrompida. Parece-me que a cena não perderia nada se tirássemos dela quatro versos, e você pode fazer então para Tamagno uma frase, talvez de efeito: na verdade, já está feita... assim:

'etc etc etc

Forza ai remi

Alla riva!!

Ancorate il vascello

\section{Evviva Evviva!}

Otello - sbarcato in fondo alla scena: sull'alto...

Esultate. L'orgoglio musulmano

Sepolto è in mar; nostra e del Cielo è gloria

Dopo l'armi lo vinse... gano (Entra nel Castello)

Tutti - Evviva Otello! Vittoria vittoria!

${ }^{178}$ VERDI, G. Lettere 1835-1900. Milano, Arnoldo Mondadori Editore, 2000, pp. 347-348. 
Responda-me brevemente". 179

Na estréia em Milão, em cinco de fevereiro de 1887, os papéis principais foram confiados a Tamagno (Otello), Pantaleoni (Desdêmona) e Maurel (Jago). Verdi acompanhou os ensaios de perto, e com energia, mostrando gestos e intenções aos artistas. Perto da estréia, um acontecimento interessante ocorreu: os cantores, talvez procurando saber mais sobre seus papéis, foram até o teatro conferir a encenação da peça shakespeariana feita por Emanuel, o que não agradou ao compositor. Em carta a Giulio Ricordi, seu editor, Verdi reclama:

\begin{abstract}
"Pelo amor de Deus, poupe-me de tudo que possa fatigar-me. Se eu cair doente, não permitirei mais o Otello. Tenho a mesma opinião que Boito. Os artistas fizeram mal em assistir ao Otello de Emanuel. Uma das duas [alternativas]: se nós, Boito e eu, fizemos tudo corretamente, não é necessário ver outra interpretação; se não tivemos sucesso, seria pior ainda querer modificar ou melhorar o que fizemos". ${ }^{180}$
\end{abstract}

Mas a estréia foi um sucesso estrondoso, vista por um público ávido e curioso após 16 anos de silêncio do compositor em relação a óperas. O triunfo certamente contribuiu para que Verdi, beirando os oitenta anos, ainda se lançasse junto a Boito na empreitada suprema de sua carreira que seria Falstaff.

No Rio de Janeiro, Otello foi primeiramente levada no Teatro D. Pedro II, em setembro de 1889, com Peri (Desdêmona), Cardinali (Otello) e Bartolomassi (Jago), sob a regência de Boniccioli, precedendo assim as estréias da ópera em Londres (1891) e Paris (1894).

Outras encenações se seguiriam, como a de 1894, com a soprano Gabbi no papel de Desdêmona, que recebe o seguinte comentário do crítico da Revista Teatral:

\footnotetext{
${ }^{179}$ Id. Ibid., p.359.
} 


\section{"OTHELLO}

Depois do triunfo de Gioconda, o triunfo do Othello, ou por outra o - triunfo do Yago.

E é bem justificado isso que dissemos, porque as honras da noite couberam ao barítono Caniera, que cantou e representou otimamente.

Dificilmente será igualado por outro qualquer artista e ultrapassado jamais, afirmamo-lo sem receio de erro.

A Sra. Gabbi cantou, como era de esperar, o papel de Desdêmona, dando uma suavidade e doçura divinais à canção do salgueiro e à Ave-Maria do 3ำ ato.

Othello teve no estreante, o tenor Avedano, um belíssimo intérprete que cantou a contento geral, notadamente $02^{0}$ ato em que, dissipadas as emoções naturais, o artista assenhorou-se de si e deu vigor e expressão à sua bela parte.

Mancinelli, o hábil diretor e extraordinário maestro, arrancou da orquestra belíssimos efeitos, fazendo interpretar a partitura de Verdi com uma justeza quase impossível, uma coisa admirável e extraordinária.

A ele os nossos aplausos.

Ego e Altri". ${ }^{181}$ 


\title{
PARTE 2 - OTELOS BRASILEIROS NO SÉCULO XIX
}

\section{1 - OTELO COMO PROCEDIMENTO ESTRUTURANTE 2.1.1 - MARTINS PENA: OS CIÚMES DE UM PEDESTRE}

\author{
"Consta que o ilustre ator João Caetano não gostava das \\ pachuchadas de Pena, como Ihe chamava às comédias, e preferia \\ as massudas tragédias de Domingos de Magalhães. \\ A posteridade não confirmou o juízo do grande rei da cena; \\ prefere as patacoadas do comediógrafo às pretensiosas estopadas do trágico."
} Sílvio Romero

Cabe a Martins Pena o epíteto de primeiro comediógrafo nacional, a partir da encenação de $O$ Juiz de Paz da Roça, em 1838, pela companhia de João Caetano. Como outros de seus contemporâneos, Martins Pena não ficou indiferente à representação do Othelo de Ducis, pelo mesmo João Caetano. É dele a primeira obra dramática brasileira a citar Otelo com freqüência e a utilizá-lo como referência para caracterizar uma personagem: Os Ciúmes de um Pedestre ou o Terrível Capitão do Mato, uma comédia em um ato, que foi escrita por Martins Pena em 1845 e representada em 05/07/1846. Na época, a obra não foi publicada, porém duas versões manuscritas (conhecidas como $\mathrm{A} \mathrm{e}$ B) são encontradas nos arquivos da Biblioteca Nacional. Nelas, há algumas divergências, como, por exemplo, quanto ao nome de algumas personagens. A versão $B$ tem o parecer da censura e a rubrica do Conservatório Dramático Brasileiro. Aparentemente, a primeira versão, cujo título era simplesmente Os Ciúmes de um Pedestre, não fora aceita; com emendas e mudanças, além do novo título $O$ Capitão do Mato, a peça foi novamente submetida à apreciação dos censores em 18/11/1845, que a liberaram para representação.

Vilma Arêas, comentando que a obra traz paródias de Otelo, de Pedro-Sem e de melodramas, coloca o foco na escolha do protagonista:

\footnotetext{
"Não pela primeira vez (e lembramo-nos de O Juiz de Paz da Roça), o obtusidade do protagonista - geradora da ação cômica - possui uma justificativa contextual, explicitada pela minuciosa crônica através da qual
} 
Martins Pena nos descreve a figura desse oficial subalterno da polícia, o pedestre. Ele pode ser mesmo considerado o escorço do modelo autoritário do país, e sua loucura, a exacerbação de sua própria função de vigia e perseguidor dos negros fugidos. Transposta para dentro de casa, essa função transforma-se na perseguição e tirania para com as mulheres (sua esposa e filha), que, aliás, descrevem-se a si mesmas como escravas. (...) Os Ciúmes de um Pedestre coloca-se (...) como um jogo de alternativas em vários níveis: entradas e saídas, luz e escuridão, morte versus ressurreição, etc., num ritmo extremamente veloz que mistura melodrama, paródia e os recursos cômicos de praxe". ${ }^{182}$

A ação se passa em uma "sala ordinária", onde há uma mesa, um armário e uma escada que deve levar a uma trapeira sobre o telhado. Ao subir o pano, ouvimos o soar da meia-noite. A cena está às escuras. Paulino surge no topo da escada e desce até o palco, comentando que o Pedestre, Mestre André, saiu em busca de negros fugidos, e que ele próprio vem em busca de sua amada, Anacleta.

Balbina surge por um buraco da porta, chamando a madrasta, e Paulino põe-se a escutar. D. Anacleta, de outro quarto, diz a ela que vá dormir, mas a moça insiste, com medo, pois ouvira um barulho no forro da casa. Balbina está no escuro e quer sair. D. Anacleta comenta que ambas as portas estão fechadas e as chaves estão com o Pedestre. Sempre que ele sai, deixa as duas trancadas, cada uma em um quarto, com receio de que a mulher e a filha o enganem. Inconformadas, as duas dizem que ainda vão "pregar-lhe uma" em vingança. Paulino gosta do que ouve.

Enquanto Balbina vai tentar acender uma vela, e sem saber que Paulino a escuta, Anacleta reclama do ciúme do marido e afirma que, se o Pedestre não fosse tão ciumento, talvez ela nem tivesse prestado atenção no vizinho; mas agora, ela decide que vai namorá-lo, nem que seja só por vingança. Animado, Paulino revela estar ali, o que assusta Anacleta: ela começa a gritar que há ladrões na casa. Ele tenta acalmá-la, mas ela não ouve; ele então lhe passa

${ }^{182}$ ARÊAS, Vilma Sant'Anna. Na Tapera de Santa Cruz - Uma Leitura de Martins Pena. São Paulo, 
uma cartinha por baixo da porta. Balbina ouve a gritaria e fica aflita também, pois ouve Paulino cair sobre uma cadeira. Ele resolve escapar, mas, no escuro, não encontra a escada. Ouvindo os passos do Pedestre, que chega, ele tenta fugir, mas a escada se quebra e ele vai esconder-se no armário.

O Pedestre entra com uma lanterna, trazendo preso Alexandre, que está "disfarçado em negro". Ele questiona o jovem, que diz ser escravo de um senhor na Tijuca. O Pedestre comenta que o levará para lá em quatro dias, quando a recompensa melhorar. Quer prendê-lo em um dos quartos, mas a porta está trancada, e a chave fica no quarto de Balbina. Mestre João vai ao quarto da filha, que grita. Sozinho em cena, Alexandre revela que se disfarçara para poder entrar na casa e ver sua amada Balbina. Ao mesmo tempo, Paulino reflete sobre como escapar, e Anacleta observa a cena pelo buraco da porta; vê um negro na sala e se pergunta onde estaria o vizinho, cuja carta recebera.

Balbina entra com o pai, explicando que ouvira ladrões. Ao ver Alexandre, fica muito surpresa. Ele tenta mostrar uma cartinha que trouxera, e o Pedestre percebe e fica enfurecido, inclusive com a moça. Ele lê a carta, que propõe uma fuga e casamento. Mas a carta não está assinada, e o Pedestre ignora que o autor seja o próprio Alexandre. Passa a questioná-lo sobre o remetente, mas Alexandre finge não saber. O Pedestre diz ao suposto escravo que vai the dar uma surra, e o prende em um quarto. Depois, ameaça a filha com uma palmatória. Balbina implora piedade, argumentando que ela não tem culpa se Ihe escrevem. Diz não saber quem é o remetente, mas o pai, desconfiado, manda a moça chamar Anacleta, pretendendo interrogá-la.

Enquanto isso, Paulino, Alarmado, continua escondido no armário sem saber o que fazer. Julgando-se a sós, o Pedestre reflete:

"PEDESTRE - Veremos quem é capaz de lograr-me... Lograr André Camarão! Cá a menina, levarei a palmatória. Santa panacéia para namoros! E a minha mulher... Oh, se lhe passar somente pela ponta dos cabelos a idéia de enganar-me, de se deixar seduzir... Ah, nem falar nisso, 
nem pensar! Eu seria um tigre, um leão, um elefante! A mataria, a enterraria, a esfolaria viva. Oh, já tremo de furor! Vi muitas vezes Otelo no teatro, quando ia para a platéia por ordem superior. O crime de Otelo é uma migalha, uma ninharia, uma nonada, comparado com o meu... Enganar-me! Enganar, ela! Ah, nem sei do que seria capaz! Amarrados ela e o seu amante, os mandaria de presente ao diabo, acabariam na ponta desta espada, nas unhas destas mãos, no talão destas botas! Nem quero dizer do que seria capaz." 183

É a primeira referência à encenação de Otelo, e o Pedestre inicia uma comparação com animais citados no texto de Ducis - o tigre e o leão - e passa a tratar especificamente do ciúme. Vemos aqui a primeira comédia brasileira na qual o marido ciumento é identificado com a figura do Mouro de Veneza, uma identificação que terá longo alcance. Porém, as relações da comédia de Martins Pena com Otelo não acabam na citação acima.

Voltando as mulheres à cena, o Pedestre manda Balbina fazer café e põe-se a questionar a esposa. Anacleta afirma nada saber a respeito de um suposto amante da enteada, mas o marido não acredita em suas palavras. Cansada da vida que tem levado, Anacleta ameaça fugir, e narra sua trajetória: deixada na roda dos enjeitados pela mãe e criada na Santa Casa, saíra de lá para casarse com o Pedestre, cujo único interesse nela fora o dote. Anacleta aponta ao Pedestre como seu ciúme doentio havia destruído a vida de sua primeira esposa, a mãe de Balbina, e percebe que seu marido não tem coração. 0 Pedestre retruca que nada falta a ela, a não ser a liberdade, e que se tivesse a menor suspeita em relação à fidelidade de Anacleta, ele a mataria. Ela está assustada, e ele acaba por ver, escondida com ela, a carta de Paulino. Arrebatando-a, força a esposa a lê-la.

Já convencido da culpa da mulher, o Pedestre ecoa novamente a personagem Otelo, ao dizer:

"PEDESTRE - Já fizeste as tuas orações? ${ }^{183}$ MARTINS PENA, L. C. Teatro de Martins Pena, edição crítica por Darcy Damasceno. Rio de Janeiro,
MEC, Instituto Nacional do Livro, 1956, p. 502. 
ANACLETA - Que queres tu dizer?

PEDESTRE - Recomenda tua alma a Deus, que eu esperarei um instante." 184

É a vez de Anacleta implorar piedade, no instante em que Balbina entra com o café. O Pedestre joga-o pelos ares, desembainha a espada, e parte para cima da esposa, que tenta escapar. Alexandre, de dentro, grita, desviando a atenção do Pedestre por um momento. Mas ele está decidido a matar Anacleta, que sai de cena perseguida pelo marido. Alexandre pede a Balbina que o solte para que fujam, e Paulino compreende o disfarce do moço. Ouvem-se, dentro, gritos e barulho, e o Pedestre retorna à cena, acreditando que Anacleta está morta. Ele oscila entre acreditar na culpa ou na inocência da esposa:

"PEDESTRE, como assustado - Ela me enganava... Está morta! Morta! E agora? Enterra-se... e fico descansado. Sim, descansado, tranqüilo. Amanhã pergunta-me-ão por ela e eu... Oh, talvez fizesse mal... Mal? Se ela estivesse inocente... Inocente... Oh! (Com ternura) Anacleta, Anacleta! Mas ela traiu-me, fiz muito bem... $O$ homem deve vingar-se... (Com ternura) Anacleta! Vem gente...

BALBINA, entrando - Meu pai, meu pai, talvez ainda seja tempo de a salvar! Ela rolou pelas escadas abaixo e lá está caída, fria e sem sentidos... Acuda-a!

PEDESTRE - Não, ela traiu-me; esqueceu-se do meu nome, do meu amor e de minha confiança.

BALBINA - Venha, ou vá chamar um médico!

PEDESTRE, com voz terrível - Não!

BALBINA - Meu Deus, compadecei-vos de nós! (Sai.)

PEDESTRE - Morta, morta, morta! Talvez não fosse culpada; talvez, quem sabe? Que abismo! Inocente! Mas a carta, a carta? Teu marido é um animal... Animal! Oh, se tivesse o indigno sedutor debaixo dos pés, se o visse tremendo, enfiado nesta espada, ah! Seria feliz! Pérfida! Insultado, desonrado! Oh, quisera nadar em sangue! Pérfida! (Passeia agitado pela sala.) Esta escada quebrada... Desceria ele por aqui?"185

\footnotetext{
${ }^{184}$ Id. Ibid., p. 505.

${ }^{185}$ Id. Ibid., p. 507.
} 
Desconfiado, o Pedestre vai seguindo as pistas deixadas por Paulino (a escada, um boné), e finalmente o descobre dentro do armário. Paulino tenta escapar, mas o Pedestre joga-lhe uma estocada por trás. Imediatamente, Paulino joga-se no chão, fingindo estar morto. O comentário do Pedestre é a mesma fala do Othelo de Ducis:

\section{"PEDESTRE - (...) Fiz o que devia."186}

O Pedestre reflete sobre o que fazer com os corpos, a fim de escapar da forca. Tem finalmente uma idéia e vai até o quarto onde está Alexandre. Paulino comenta que vai ter que continuar fingindo-se de morto até que consiga fugir, e volta a deitar. O Pedestre retorna com o suposto escravo, ordenando-Ihe que coloque Paulino em um saco para jogá-lo ao mar. Alexandre vê aí a possibilidade de livrar-se do castigo, e concorda. Os Dois põem Paulino em um saco, e o Pedestre sai para ver se há gente na rua. De dentro do saco, Paulino explica a Alexandre que está vivo, e que viera em busca de Anacleta, como o outro viera por Balbina. Propõe-lhe que fujam os quatro. Ao invés de responder-Ihe, Alexandre sai correndo chamando por Balbina, e Paulino fica sem saber qual a sua situação. Espera dentro do saco até que Alexandre retorna com Balbina. Alexandre elaborou seu próprio plano: tira Paulino do saco e ali coloca sua amada. Paulino volta a esconder-se no armário e o Pedestre, sem desconfiar da troca, vem dizer a Alexandre que podem sair. Este carrega o saco e é seguido pelo Pedestre, que apaga a vela e tranca a porta por fora.

Preso na casa, no escuro, Paulino crê estar a sós com a morta Anacleta, e treme de medo; Anacleta, porém, aparece e explica que não morrera, apenas desmaiara. Os amores de Paulino pela jovem, após tantas aventuras, diminuíram; o namoro que ainda não aconteceu demonstra dar muito trabalho. Assim, quando Anacleta propõe ao vizinho que fujam do Pedestre, ele diz preferir fugir dela, e de todas as mulheres, se for possível.

\footnotetext{
${ }^{186}$ Id. Ibid., p. 508. A fala do Othelo duciano é "eu fiz o que devia", em MAGALHÃES, D.J.G. de. Obras de D.J.G. de Magalhães - tomo III - Tragédias. Rio de Janeiro, Livraria de B.L. Garnier, 1865, p. 357, e é citada por João Caetano nas Lições Dramáticas, p. 12, onde o ator explica como a frase deve ser dita (vide capítulo 1.2.2).
} 
Ouvindo o Pedestre, que retorna, a esposa e o vizinho correm a esconder-se, um para cada lado. O Pedestre comenta que uma patrulha os encontrara, e que o escravo provavelmente não teria conseguido escapar com o saco. Está muito nervoso pois crê que o negro pode dar com a língua nos dentes e revelar onde o Pedestre mora.

Ao ir fechar a porta, o Pedestre encontra Roberto, que chega. Este vem explicar que, após dezoito anos na África e na Índia fazendo fortuna, acaba de desembarcar no Rio de Janeiro e está à procura de sua filha, que fora deixada por ele na roda dos enjeitados com uma cruz de ouro, após a mãe haver morrido e ele ter que partir. Logo fica claro que sua filha é Anacleta - para desespero do Pedestre, que acredita ter descoberto um sogro rico logo após matar a esposa. Anacleta e Paulino, surpresos, ouvem tudo pelos buracos das portas. O Pedestre acaba confessando a Roberto que assassinara a filha deste. Roberto fica transtornado e jura vingança. Subitamente, Anacleta surge, sem poder conter-se, e abraça o pai. O Pedestre crê estar diante de uma alma penada. Aterrorizado, ele se recolhe até a porta da esquerda, enquanto Anacleta e Roberto conversam, e ouve Paulino tentando acalmá-lo. O efeito é o contrário: acreditando serem dois os fantasmas, o Pedestre corre para a porta, onde se depara com Alexandre, ainda com o saco às costas, que vem preso pela patrulha. O Pedestre recua, a tremer, caindo de joelhos. O Cabo inquire pelo dono da casa, e diz ao Pedestre que encontrara um escravo fugindo com um cadáver dentro de um saco. Roberto se assusta, e o Pedestre ainda mais, apontando para Paulino e afirmando que ali está a alma do morto. Paulino ri, mas o Pedestre sustenta que o matara, assim como fizera a Anacleta. Ambos os "mortos" se declaram vivos. Balbina sai do saco, viva também, o que leva o Pedestre a exclamar para todos:

"PEDESTRE - Mulher, eu te matei... Eu o matei também (Apontando para Paulino) E tu e ele ficaram vivos nesta casa, juntos, fechados... e fechados por mim, por mim próprio! Oh, de que me serviu trancar portas e fazer duas mortes? (Dirigindo-se para Balbina) E tu te deixaste furtar por um negro, que eu mesmo conduzi para fora de casa... Oh, de que me serviram 
as fechaduras, os cuidados, os ciúmes, a palmatória? Oh, estou desenganado! (Dirigindo-se para Roberto) Senhor, levai vossa filha, que já me não pertence... Eu a matei, estou viúvo... Dai-lhe todos os vossos navios e riquezas; ide morar com ela em um palácio, que eu não... Em um palácio! Oh, em um palácio, que tem tantas portas e janelas! Ah, esta casa só tinha uma porta, e assim mesmo... Não, não, levai-a... Não sei, não posso vigiar mulheres, estou desenganado, vou ser frade!"187

O Pedestre, indignado com a filha, ordena-lhe que se case com o negro. Satisfeito, Alexandre limpa o rosto (o que não deixa de ser uma brincadeira com a convenção teatral dos atores brancos pintarem o rosto para interpretar negros) e se revela ao Pedestre. É a gota d'água para mestre André João; ele implora aos soldados que o levem preso para um convento, repetindo que quer ser frade. Paulino se despede, Anacleta e Roberto comemoram, e Alexandre se declara a Balbina, enquanto podemos ouvir ainda, de fora, o Pedestre gritar: "Quero ser frade!"

É inegável que a comédia tem momentos que realmente incitam o riso, em um jogo urdido pelo dramaturgo em relação a seu protagonista, às outras personagens, à trama e às referências externas, dentre as quais destaca-se Otelo. Como afirma Arêas:

\begin{abstract}
"Os fios das várias tramas e o jogo de distorções causado pelos recursos paródicos são de extrema complexidade e misturam-se se confrontados. Por exemplo, se Otelo é negro e insigne estrategista, o pedestre, ao contrário, é oficial subalterno, revelando-se ao mesmo tempo absolutamente incompetente. Além disso, sendo branco, caça negros. O 'negro' da peça é desempenhado por Alexandre, maquilado para o papel, o que nos remete ao mesmo tempo para uma necessidade do enredo e para o caráter metalingüístico da peça." ${ }^{188}$
\end{abstract}

A autora explica que o final da peça distancia-se dos princípios do teatro clássico, até porque o próprio triângulo amoroso principal fica sem uma solução

\footnotetext{
${ }^{187}$ Id. Ibid., p. 518.

${ }^{188}$ ARÊAS, Vilma Sant'Anna. Op. Cit., p. 214.
} 
tradicional. Ao fazer isso, segue comicamente os passos da tragédia, especialmente de Otelo. Este, após matar Hedelmonda, ao saber de seu engano, enlouquece e se mata. Já André João, o pedestre, tendo prendido, no final prende-se.

Os Ciúmes de um Pedestre é um exercício dramático que se vale de qüiproquós e coincidências, e que diverte o espectador. É uma peça que

\begin{abstract}
"enreda em sua complicadíssima trama (com dois pais, duas mães mortas, duas filhas, dois amantes, duas cartas reveladoras e não sei quantas peripécias levando a reconhecimentos verdadeiros e falsos) ecos de outras peças, uma dentro das outras: Anacleta, por exemplo, recita trechos inteiros do Otelo, como a cena da leitura da carta, e está ao mesmo tempo dentro do tradicional melodrama, com órfãs, cruzinhas de identificação, pai reencontrado, salto da pobreza à riqueza, etc." ${ }^{189}$
\end{abstract}

Podemos refletir ainda sobre a referência ao Otelo, não simplesmente como a obra de Ducis, mas como a encenação de João Caetano, que o Pedestre afirma ter visto estando de serviço no teatro. Não há referência a qualquer mérito artístico; é um simples pretexto para a comparação da grandeza de seu ciúme. Mas não deixa de ser um ponto que promove o riso, mesmo se em nada homenageie a encenação de João Caetano.

Na verdade, parece que, além de retornar ao Othelo de Ducis - como Macedo o fará - Martins Pena lança o foco sobre João Caetano e sua encenação, e a parodia. O selvagem Mouro, filho do deserto, ressoa no potencial de selvageria do próprio pedestre, que se identifica com a personagem. Quando o Pedestre narra suas idas ao teatro, e diz que "já treme de furor"190, ele está se referindo a um estilo de interpretação, aqui em registro cômico, mas que é tratado seriamente pelo próprio João Caetano, pra quem o furor é imprescindível na representação. Como ele afirma nas Lições Dramáticas:

\footnotetext{
${ }^{189}$ Id. Ibid., p 252.

${ }^{190}$ MARTINS PENA, L.C. Op. Cit., p. 502.
} 
"É preciso observarem bem, Senhores, que as coisas mais sérias são as mais próximas do riso, e por conseqüência é muito fácil quando se procura pintar o furor cair no ridículo; por isso não é semelhante lance para todos, pelo que Ihes faço a seguinte observação: nem todos os furores são da mesma espécie, o que Ihes provo como um pequeno exemplo; os de Otelo são por um amor desesperado; os de Oscar a pena de um delito involuntário; os de Hamleto, o horror de ver-se executar da vingança paterna, contra sua própria mãe; os de Pedro, na Castro, sugeridos pela injusta morte da esposa que tanto amava; enfim, todos estes e muitos outros que somos obrigados a representar, têm caracteres diferentes; pelo que devemos na pintura deles pôr sempre diante dos olhos dos espectadores o sentimento correspondente". ${ }^{191}$

Outros elementos paródicos incluem o episódio da volta de Roberto, o pai de Anacleta, agora rico, em busca da filha que perdera e que traz consigo uma jóia que a identifica. O recurso, típico do melodrama - base de grande parte do repertório de João Caetano - aqui se torna mais um motivo de riso, pelo o desespero do Pedestre perante a situação inusitada, ele que crê ter matado a esposa. Tudo isso, seguindo as características do autor, de tratar comicamente certos tipos do panorama fluminense.

A obra não parece ter tido muito fôlego nos palcos, tendo sido representada apenas em 1846. Também não foi publicada na época, e nem nas primeiras edições coletivas das peças de Martins Pena, em 1891, 1914, 1927 e 1948; apenas na edição mais completa das comédias, feita pelo Instituto Nacional do Livro em 1956, a peça seria finalmente editada. Sua liberação para os palcos, na época da composição, foi complicada, exatamente pela paródia ao Otelo de João Caetano, que causou "verdadeira indignação à comissão de censura teatral(...), achando imprudentíssimo o gracejo de arremedar 'o único ator brasileiro que entre nós tem representado o papel de Otelo"' ${ }^{192}$.

Martins Pena tentou defender-se, argumentando que não tentara atacar João Caetano, mas unicamente parodiar a peça de Ducis, como afirma em seus

${ }^{191}$ SANTOS, João Caetano dos. Lições Dramáticas. Rio de Janeiro, Serviço de Documentação - MEC, 1955, p. 52. 
Folhetins $^{193}$. Mas ainda assim teve que fazer mudanças no texto para vê-lo aprovado e, finalmente, representado.

192 ARÊAS, Vilma Sant'Anna. Op. Cit., p. 241 e 254.

${ }^{193}$ Citado por ARÊAS, Vilma Sant' Anna. Op. Cit., p. 255. 


\title{
2.1.2 - A DESDÊMONA AMBÍGUA: LEONOR DE MENDONÇA, DE GONÇALVES DIAS
}

\author{
“A complexidade patológica de D. Jaime, a doçura estática \\ e trêmula de Leonor, a deliciosa cena familiar na casa dos Alcoforado, \\ a função de contraponto naturalístico de uma Paula - são coisas \\ de tragediógrafo nato. E o último ato (a batalha de Leonor contra a morte) \\ faz arder, em um fogo só, realidade e símbolo, psicologia e abstração, \\ como só as páginas deveras eternas do teatro conseguem."
}

Ruggero Jacobbi

Enquanto Martins Pena (assim como, depois, Joaquim Manuel de Macedo) se concentrou no potencial cômico de Otelo e na própria representação deste por João Caetano, Gonçalves Dias afigura-se como um dos primeiros leitores do Otelo shakespeariano no Brasil, e usa desta fonte para compor a melhor de suas peças, quiçá de toda a literatura dramática brasileira do século $\mathrm{XIX}^{194}$, que traz por título o nome da protagonista. $O$ drama em três atos e cinco quadros de 1846 descende de Shakespeare em um período em que a versão de Ducis ainda era a que corria no Brasil, por conta principalmente da marcante interpretação de João Caetano - para quem, aliás, Leonor de Mendonça foi escrita, e por quem foi rejeitada (a peça só estrearia no Rio de Janeiro com a encenação do Teatro do Estudante do Brasil, dirigida por Esther Leão, e em São Paulo em 1954, com a montagem do Teatro Brasileiro de Comédia.

Gonçalves Dias foi buscar a inspiração para seu enredo em um fato histórico português ocorrido em 1512, quando D. Jaime de Bragança matou sua esposa Leonor sob pretexto de adultério, apesar do testemunho do padre confessor da esposa, que defendeu sua inocência. O fato, narrado na História Genealógica da Casa Real Portuguesa, Vida do Duque D. Jaime, deixava margem à ambigüidade - teria sido Leonor inocente ou culpada?

Na peça, tal enredo é desenvolvido da seguinte forma: no primeiro ato, em uma conversa entre Leonor e sua criada Paula, conhecemos o caráter terrível do 
duque e o interesse do jovem Alcoforado pela duquesa. Descobrimos também que o moço roubara de Paula uma fita de cetim pertencente a Leonor, que ordena à criada que a recupere.

Alcoforado vem pedir a proteção da duquesa, que promete interceder junto ao marido para enviá-lo à África para lutar por Portugal. Tendo tomado de volta sua fita do barrete do rapaz, acaba dando-Ihe a mesma novamente como uma memória. Alcoforado joga-se aos pés de Leonor no momento em que o duque é anunciado. O jovem sai e Leonor comenta que fora imprudente. Mesmo assim, fala ao marido sobre a partida do moço. D. Jaime fala de seus sofrimentos anteriores, de cujas lembranças não consegue escapar. Aflito, resolve sair para uma caçada, a fim de acalmar-se. Leonor concorda em acompanhá-lo.

O segundo quadro traz a cena após a caçada, na qual Alcoforado salvara a vida de Leonor abatendo um javali. O duque insiste que a esposa agradeça seu salvador remunerando-o como the aprouver. D. Jaime tem um acesso de terror ao ver um copo d'água, atemorizando a duquesa. Ele insta Leonor a partir para a corte antes que seus ataques culminem em desgraça. A seguir, Alcoforado minimiza seu feito frente à duquesa, e fala de seu sofrimento por ela e de seus maus pressentimentos. Mesmo assim, ousa pedir a ela uma entrevista a sós para abrir seu coração. Leonor acaba concordando, e diz que mandará notícias pela criada.

O segundo ato mostra a cena familiar, na qual Alcoforado, em casa, conversa com o irmão, a irmã e o pai, preparando-se para sair à noite mas negando-se a revelar aonde vai. O pai o questiona mas acaba compreendendo, e o jovem sai levando a espada do irmão. Entretanto, no palácio, o criado Fernão vem advertir o duque sobre uma carta de Leonor a Alcoforado marcando um encontro. D. Jaime, em cólera, prepara uma armadilha e ameaça Fernão, caso tudo não seja verdade.

\footnotetext{
${ }^{194}$ Sobre Leonor e sua importância, vide MAGALDI, Sábato. Panorama do Teatro Brasileiro. $3^{a}$ ed. São Paulo, Global, 1997, pp. 71-79.
} 
No terceiro ato, Alcoforado chega ao quarto de Leonor e declara seu amor, sabendo que vai partir e que deve morrer em combate. A duquesa expressa um amor "de mãe", desvelado, mas o diálogo é interrompido por Paula que avisa que há homens armados pelos corredores. Leonor faz o jovem prometer que não lutará contra o duque, que os descobre e os acusa. Alcoforado conforma-se em ser punido mas tenta convencer D. Jaime da inocência de sua esposa. $\mathrm{O}$ duque sumariamente o condena à morte pelas mãos de um escravo.

$\mathrm{Na}$ última cena, Leonor, presa em seu quarto, reflete sobre a sua situação. Paula Ihe traz os filhos, e logo depois o padre Lopo Garcia vem confessá-la. Leonor conta todo o ocorrido e seus sentimentos para com o duque e o Alcoforado. Quando D. Jaime chega, o padre afirma que Leonor é inocente antes de sair. A duquesa tenta argumentar com o marido, em vão. Enfim, todos os servos do castelo se recusam a matar Leonor, seguindo a recomendação de Lopo Garcia. Por um momento Leonor crê na sua salvação, mas o duque decide ser ele mesmo o executor, arrastando-a para fora da cena.

O próprio prólogo da peça, "uma das páginas mais lúcidas e penetrantes de estética na nossa literatura", nas palavras de Sábato Magaldi ${ }^{195}$, revela as escolhas e os pontos de vista do autor sobre sua obra e sobre a arte dramática em geral. Ali, o dramaturgo explica o que tentara fazer: a ação que escolhera e os dois caminhos possíveis a seguir:

"A ação do drama é a morte de Leonor de Mendonça por seu marido: dizem os escritores do tempo que D. Jaime, induzido por falsas aparências, matou sua mulher; dizem-no, porém, de tal maneira, que facilmente podemos conjecturar que não foram tão falsas as aparências como eles no-las indicam. O autor podia então escolher entre a verdade moral ou a verdade histórica - Leonor de Mendonça culpada e condenada, ou Leonor de Mendonça inocente e assassinada. Certo que a primeira oferecia mais interesse para a cena e mais moral para o drama (...) “196

\footnotetext{
${ }^{195}$ Id. Ibid., p. 75.

${ }^{196}$ DIAS, A. Gonçalves. Teatro Completo. Rio de Janeiro, SNT, 1979, p. 60.
} 
Apesar disso, o dramaturgo escolhe o outro caminho, pensando na fatalidade que deriva da civilização e da vida dos homens e que determina o destino de Leonor. Com isso, Gonçalves Dias nega o caminho do melodrama - implícito na primeira opção - e constrói um drama romântico de alto nível.

É no mesmo prólogo que Gonçalves Dias reconhece o papel exercido, em sua composição, pelo Otelo - de Shakespeare, como ele próprio frisa, já que a versão corrente no Brasil ainda era a de Ducis. Realmente, ao longo do texto de Leonor de Mendonça, há inúmeras passagens que remetem à peça shakespeariana, como D. Jaime chamar Leonor de "minha bela guerreira"197, mesmo epíteto aplicado a Desdêmona por Otelo (II, i $)^{198}$.

Sempre devemos lembrar que Décio de Almeida Prado, ao dedicar todo um capítulo de seu livro Teatro de Anchieta a Alencar à peça Leonor de Mendonça, -por suas incontestáveis qualidades, deixou claro que, apesar de certos elementos comuns, a obra de Gonçalves Dias não derivava diretamente do Otelo:

\begin{abstract}
"A peça brasileira pertence a outra linhagem. Se quiséssemos encontrar paradigmas para ela, teríamos de ir buscá-los em fontes românticas bem mais distantes: em Tristão e Isolda, por exemplo. Ou, então, bem mais próxima: o Antony, de Alexandre Dumas, e o Chatterton, de Alfred de Vigny. (...) São situações, personagens e entrechos inconfundíveis, mas que apresentam a mesma estrutura de enredo: um casamento sem amor, com a esposa muito mais jovem do que o marido; o rapaz solteiro que se apaixona pela mulher casada, sendo correspondido espiritual ou materialmente; e a morte de ambos". ${ }^{199}$
\end{abstract}

Na verdade, Décio de Almeida Prado não quer focar em Otelo, e só o cita pois os críticos Ruggero Jacobbi e Sábato Magaldi haviam já se ocupado das relações entre os dois textos. Mas o crítico apressa-se a retorquir que o próprio

\footnotetext{
${ }^{197}$ Id. Ibid., p. 82.

${ }^{198}$ SHAKESPEARE, William. Otelo, o Mouro de Veneza, tradução de Bárbara Heliodora. Rio de Janeiro, Lacerda Ed., 1999, p. 57.

${ }^{199}$ PRADO, Décio de Almeida. Teatro de Anchieta a Alencar. São Paulo, Perspectiva, 1993, p. 289.
} 
Gonçalves Dias citara a obra shakespeariana em seu prólogo apenas para afirmar as distinções entre as duas peças.

Ainda que possamos concordar que a filiação de Leonor de Mendonça a Shakespeare não seja central, ou pelo menos a única, podemos, ainda assim, investigar um pouco mais a fundo os elementos de Otelo que perpassam Leonor - e não são tão poucos assim.

Em termos de enredo, a ligação mais evidente, que fora citada por Jacobbi e Magaldi e refutada por Décio, é a fita de Leonor que, como o lenço de Desdêmona, transforma-se em uma "prova" da traição feminina aos olhos do marido desconfiado. Além disso, Leonor intercede junto ao marido em relação ao destino militar do jovem Alcoforado a pedido do mesmo, uma situação análoga à de Desdêmona em relação a Otelo e Cássio. Em ambos os casos, a posição de comando de Otelo e do duque determina a ajuda requerida por Alcoforado e por Cássio a Leonor e Desdêmona respectivamente.

Há passagens com paralelos mais específicos, notadamente a da reação do duque às informações trazidas por Fernão, demandando provas e ameaçando o criado, como Otelo faz com lago. No texto de Gonçalves Dias, temos:

\footnotetext{
"FERNÃO - Senhor, as minhas palavras não são evangelho; pode ser que me iludissem: moderai-vos!

O DUQUE - Nasceste em minha casa, acompanhaste a meu pai na sua última hora, acompanhaste-me no meu desterro e encaneceste no meu serviço; pois juro-te que, se esta noite o infame não for encontrado neste palácio, morrerás como um cão!"200
}

O trecho ecoa a cena em Shakespeare (III, iii):

"OTELO - É bom provar que meu amor é puta, (toma-o pela garganta.)

Quero certeza, provas oculares,

${ }^{200}$ DIAS, A. Gonçalves. Op. Cit., p. 112. 
Ou, pela alma imortal do homem,

Melhor seria que nascesse um cão

Que despertar-me a ira.

IAGO - É isso, então?

OTELO - Faça-me ver, ou ter tal prova ao menos,

Que não me reste aspecto nem detalhe

Que deixe dúvida: pois senão, morre!"201

Algumas de tais semelhanças são elencadas no prólogo. Contudo, Gonçalves Dias delineia também as diferenças essenciais entre Otelo e D. Jaime, defendendo a originalidade de seu texto:

"O duque é nobre e desgraçado; da nobreza tem o orgulho, da desgraça a desconfiança, e do tempo a vida e a superstição. O duque é cioso, e, notável coisa! É cioso não porque ama, mas porque é nobre. É esta a diferença que há entre Otelo e D. Jaime. Otelo é cioso porque ama, D. Jaime porque tem orgulho. Ambos são crédulos e violentos, mas a credulidade de Otelo forma-se e caminha a passos lentos, porque o seu amor duvida; a sua violência, relevem-me a expressão, é vagarosa e caminha com a terrível majestade das lavas de um vulcão. O duque crê quanto basta ao bom senso de qualquer homem, e a sua violência é precipitada, porque ele não se interessa com a inocência da esposa. Otelo mata a Desdêmona, mas chora antes de a matar e depois de a ter morto; o duque mata a Leonor de Mendonça, mas sem lágrimas, porque o orgulho não as tem.

"Se me é permitido continuar com o drama além dos seus termos naturais, vejamos o que fazem estes dois homens depois de assassinadas suas mulheres. Otelo mata-se; e D. Jaime, convencido da inocência da sua por tantos e tão grandes milagres que testemunharam o seu martírio, irá batalhar contra infiéis em expiação do seu crime, e voltará purificado para de novo casar-se. Assim, pois, quando o primeiro acaba a vida, é que o segundo principia a viver". ${ }^{202}$

${ }^{201}$ SHAKESPEARE, W. Op. Cit., p. 106.

${ }^{202}$ DIAS , A. Gonçalves. Op. Cit., pp. 61-62. 
Gonçalves Dias explica detalhadamente a composição das outras personagens e suas interações para criar o drama, expondo o domínio sobre sua composição, mas sem se referir mais à peça shakespeariana. Contudo, voltando a Otelo, podemos imediatamente fazer o paralelo não apenas entre D. Jaime e Otelo e entre Leonor e Desdêmona mas também, por exemplo, entre Paula e Emília, as duas criadas dedicadas mas um pouco imprudentes nos episódios similares da fita e do lenço, respectivamente. O jovem Alcoforado evoca Cássio, porém seus sentimentos para com Leonor o afastam da personagem de Shakespeare. O que mais salta aos olhos na obra brasileira, e que é a origem de uma grande diferença, é a ausência do motor da peça shakespeariana, lago. É verdade que temos a cena na qual D. Jaime tem suas suspeitas inflamadas pelas informações de um subordinado, como já vimos, mas Fernão é, em tudo, a antítese de lago: um criado fiel, que não busca vantagem alguma e que realmente se preocupa com seu amo.

Claro está que o esquema otelino não explica a peça toda. Sem dúvida, Otelo funciona como pano de fundo para Leonor de Mendonça não só pelas semelhanças quanto pelas diferenças, algumas claramente delineadas e expressas pelo autor. Gonçalves Dias explica muito bem a distinção entre Otelo e o duque, mas não discorre sobre os pontos em comum e as disparidades entre Leonor e Desdêmona, que inclusive determinam o fato da duquesa, e não seu marido, ser a protagonista de sua obra. Ele indica os defeitos de sua heroína, e comenta sobre o seu caráter, mas sem aprofundarse em relação ao modelo shakespeariano. O quanto de Desdêmona há em Leonor? Gonçalves Dias nos informa que quis fazer Leonor inocente - o contrário transformaria a peça em um melodrama ${ }^{203}$ - e concretamente a faz, mas... será ela tão inocente assim? Apesar do dramaturgo não desenvolver tal ponto, Leonor não é Desdêmona, e a imprudência da primeira - que ela mesma confessa - é diferente da ingenuidade da segunda. Pode não ter crimes ou vícios, apenas defeitos, como afirma o autor, mas quanto tempo ela resistiria ao jovem Alcoforado, apaixonado por ela? Talvez indefinidamente, ao menos concretamente, mas não temos certeza. Desde antes do jovem salvar-

\footnotetext{
${ }^{203}$ Vide CORREIA, Marlene de Castro. "O Teatro de Gonçalves Dias”, in DIAS, A. Gonçalves. Op. Cit., pp. 9-24.
} 
Ihe a vida, ela não consegue deixar de pensar nele, e se sobressalta por ele ter conseguido um pedaço de sua fita - a mesma fita que depois ela lhe concederia como uma lembrança, algo que Desdêmona não faria com seu lenço. Tendo concedido a entrevista ao jovem em seu quarto, após ele se declarar, ela diz:

\begin{abstract}
"DUQUESA - É à cabeceira de meus filhos que eu vos direi que vos amo; eu vos amo porque sois bom, porque sois nobre, porque sois generoso; eu vos amo porque tendes um braço forte, um coração extremoso, uma alma inocente; eu vos amo porque vos devo a vida, porque não tendes mãe e eu vos quero servir de mãe porque sofreis e eu quero ser vossa irmã. É um amor passivo e desvelado, que poderá ser reprovado na terra, mas que eu não creio que o seja nos céus". 204
\end{abstract}

Sábato Magaldi, comentando sobre este trecho, afirma:

\begin{abstract}
"Gonçalves Dias evitou, com a interferência da fatalidade, um esclarecimento difícil, que talvez roubasse à peça a delicadeza, o mais requintado clima de meio tom. Pode ser tomada apenas como origem de sentimentos futuros, interrompidos pelo destino, a confissão de Leonor a Alcoforado. (...) Não existe nessa confidência palavra que indique paixão desvairada ou a entrega carnal”205.
\end{abstract}

O "meio tom" citado pelo crítico continua pelo texto. Na cena da confissão, Leonor explica ao padre como não pudera amar seu próprio marido, e pergunta se havia alguma culpa em ter-se deixado "embalar por esse novo afeto que então principiava a sentir."206 O padre a isenta de culpa, e por ela intercede, não conseguindo porém impedir sua execução. Mas o que fica de Leonor? Seria ela a senhora protetora, inatingível ao cavaleiro, ou teria outros interesses em relação ao Alcoforado, um amor platônico que seja? Ela não é indiferente ao jovem, e disso temos exemplo por todo o texto, o que a afasta de Desdêmona e de sua relação cortês com Cássio. Desdêmona intercede pelo jovem junto a Otelo assim como Leonor pede ao duque que dê a Alcoforado o posto que ele

\footnotetext{
${ }^{204}$ Idem, ibidem, p. 116.

${ }^{205}$ MAGALDI, Sábato. Op. Cit., p. 77.
} 
deseja para lutar na África. Mas enquanto Desdêmona insiste no assunto ingenuamente, Leonor se interessa pelo destino de seu jovem protegido de outro modo. Seria ela capaz de trair D. Jaime? Essa pergunta insistente talvez seja demasiado moderna para a peça e sua época; a questão da honra e dos laços indissolúveis do matrimônio tinha outro peso. Mas o texto evolui nesse limite que jamais se resolve. Sempre podemos ver seus atos e palavras de forma inocente ou culpada, mais como Capitu do que como Desdêmona - para citarmos apenas mais uma personagem na qual há ressonâncias de Otelo. $\mathrm{Na}$ verdade, parece que, como afirma Ruggero Jacobbi:

"Esta, sim, vai além de Desdêmona: da desbotada e contraditória Desdêmona. Na tragédia de Shakespeare, o imenso, compacto Otelo encontra na mulher um contraponto; no drama do poeta brasileiro, é Dom Jaime (apesar de toda a intensidade) que serve de contraponto a Leonor. Raramente uma personagem foi tão 'protagonista'. (...) Gonçalves Dias não se preocupou com a inocência de Leonor; não quis fazer, dela, um anjo; quis mostrar ao leitor (ao espectador) que toda a criatura humana é substancialmente um anjo, atirado ao inferno de contradições e equívocos da existência." ${ }^{207}$

É essa "Desdêmona ambígua" que move a peça, a qual infelizmente não foi encenada na época de sua composição, tendo sido apenas publicada em 1847. Ao que parece, mesmo aprovada pelo Conservatório, João Caetano não quis encená-la. Hessel e Raeders afirmam:

"Mas que desilusão! Mesmo depois de aceito com elogios no Conservatório, o drama foi recusado por João Caetano sob pretexto de não haver teatro disponível e de estar comprometido, mediante contrato, com a Companhia Lírica Francesa". 208

\section{Como explica Correia,}

\footnotetext{
${ }^{206}$ DIAS, A. Gonçalves. Op. Cit., p. 128.

207 JACOBBI, Ruggero. Goethe, Schiller, Golçalves Dias. Porto Alegre, Edições da Faculdade de Filosofia, s/d, p. 83 .

${ }^{208}$ HESSEL, Lothar \& RAEDERS, Georges. Op. Cit., p. 101.
} 
"O empenho de Gonçalves Dias em ver encenada a sua Leonor e a nenhuma disposição de João Caetano em encená-la, levam o autor e o ator a viverem na vida real momentos de vaudeville, deliciosamente registrados em carta a um amigo: 'O meu drama, como creio que já te disse, foi aprovado pelo conservatório com muita soma de louvores. Leveio ao João Caetano, que me fez saber ser bom e belo o cujo sobredito drama; porém que para o levar à cena carece de me falar. Ora aqui é que a porca torce o rabo: o João Caetano é um homem temível - infatigável invisível se o procuras na Corte - está em Niterói - se o procuras em Niterói, voltou para a Corte; se o procuras em casa, está no Teatro; se no Teatro, está no escritório, se no escritório, está na rua, e hás-de concordar comigo que a rua é um lugar bem dificultoso de se topar de propósito com um indivíduo"209.

Ainda no prólogo escrito por Gonçalves Dias, é interessante ressaltar as considerações que ele faz sobre a forma do drama e sobre escrever em verso ou prosa, ou em alternância entre ambos, e para isso o exemplo que ele utiliza é o próprio Shakespeare:

"Assim, pois, o drama resume a comédia e a tragédia. Ora, se a tragédia se não pode conceber sem verso, assim também a comédia sem prosa não pode existir perfeita. Para prova disto basta que reflitamos que o melhor autor cômico do mundo, o célebre Molière, foi o primeiro que, não sem dificuldade, introduziu a prosa no teatro francês. Antes dele, até o s bons burgueses se envergonhavam de falar a linguagem do povo e a dos sábios. Patearam-no, creio eu, bem que Racine seguiu o seu exemplo. Porém, primeiro que estes excelentes dramaturgos, outro que ainda não foi excedido em arrojo e sublimidade, o afamado Shakespeare, que inventou o drama descrevendo fielmente a vida, já havia achado a verdadeira linguagem da comédia usando nela da prosa. Nos seus dramas ou crônicas foi Shakespeare conseqüente consigo, usou simultaneamente da prosa e do verso, porque simultaneamente criava em ambos os gêneros. Nós por que o não havemos de imitar? Quando ele quer exprimir uma coisa vulgar ou uma chocarrice, usa da prosa; quando quer exprimir um

\footnotetext{
${ }^{209}$ CORREIA, Marlene de Castro. Op. Cit., p. 15. A citação feita pela Autora está em PRADO, Décio de
} Almeida. João Caetano. São Paulo, Perspectiva, 1972, pp. 126-7. 
sentimento nobre ou uma exaltação do espírito, usa do verso, e não só do verso heróico como de todos os mais da língua inglesa (...). Por que não faremos nós assim? Por que havemos de dizer em verso coisas vulgares, e em prosa coisas que só em versos podem ser bem ditas? Bem é que haja harmonia entre a expressão e o pensamento, que a poesia do espírito seja interpretada pela poesia das palavras, e que o prosaico da vida seja dito em linguagem prosaica.

"Suponhamos que Shakespeare apresentava em cena uma daquelas personagens que ele se comprazia em enfeitar com todas as flores do seu gênio, Hamlet, Lear, Otelo ou Macbeth. Se no meio de um daqueles seus monólogos, em que a beleza do verso rivaliza com a sublimidade do pensamento, Ihe fosse preciso apresentar também um importuno, um servo, por exemplo, que viesse chamar seu senhor para a mesa, com certeza que ele não poria versos na boca do vilão, nem se cansaria em imaginar uma perífrase para dizer em versos: 'O jantar está posto'. Ele diria isto como vulgarmente se diz, como todos os dias o ouvimos, sem adorno mal cabido e sem majestade farçada. O prosaico da vida afugentaria a poesia do pensamento, e por conseqüência o verso". 210

Mas tal alternância Gonçalves Dias não ousara fazer em sua peça, segundo ele por ser ainda um autor desconhecido - tais inovações deveriam ser iniciadas por escritores já consagrados. O autor mostra seu receio em relação à apreciação de sua peça pela censura, e tece comentários duros a respeito do Conservatório, que contudo, como vimos, aprovaria sua obra.

O modelo shakespeariano, como podemos perceber, é bem conhecido do dramaturgo brasileiro, que o coloca como inventor do drama, em uma linha que deriva do prólogo de Cromwell de Victor Hugo e dos ideais do Romantismo. Mais do que isso, Leonor de Mendonça marca um ponto de mudança na apreciação da personagem Otelo em terras nacionais, e o uso que dela é feito. Como indica João Roberto Faria,

${ }^{210}$ DIAS, A. Gonçalves. Op. Cit., pp. 64-65. 
"O que se deve ressaltar nesse paralelo (entre Otelo e o duque) é que em meados do decênio de 1840 os autores românticos brasileiros já lêem Shakespeare. A referência não é mais o Otelo neoclássico de Ducis, que havia sido traduzido por Gonçalves de Magalhães e ainda era representado por João Caetano. Vale lembrar, a propósito, que na Revista Minerva Brasiliense, em 1844, Émile Adet já havia pedido a nossos intelectuais que traduzissem Shakespeare à semelhança do que fizera Alfred de Vigny na França, com o Otelo, e não as fracas imitações de Ducis". 211

Realmente, na Minerva Brasiliense, Émile Adet lamenta que Gonçalves de Magalhães tenha empenhado seu talento traduzindo o texto de Ducis e não o de Shakespeare, levando atrás de si outros tradutores brasileiros: A. J. de Araújo (Hamlet) e J. A. de Lemos Magalhães (Macbeth), e privando os brasileiros de conhecer essas e talvez outras obras shakespearianas, muito superiores aos textos neoclássicos franceses. ${ }^{212}$

O pedido de Émile Adet demoraria para ser atendido, mas o acesso ao texto shakespeariano começava a ser experimentado, como demonstra o exemplo de Gonçalves Dias e também, como veremos posteriormente, de Álvares de Azevedo. Contudo, a influência de Ducis e a de João Caetano ainda não haviam se esgotado como modelo otelino, e perdurariam por um bom tempo. Mais de uma década após Leonor de Mendonça, obras inspiradas pela atuação do ator carioca como Otelo ainda surgiam. É o que veremos com O Novo Othelo, de Joaquim Manuel de Macedo.

\footnotetext{
${ }^{211}$ FARIA, João Roberto. Idéias Teatrais - o Século XIX no Brasil. São Paulo, Perspectiva : FAPESP, 2001, p. 48.

${ }^{212}$ Id. Ibid., pp.337-343.
} 


\subsection{3 - O OTELO ESVAZIADO: O NOVO OTHELO, DE JOAQUIM MANUEL DE MACEDO}

O sucesso de João Caetano seria determinante na própria continuidade da atividade teatral no Brasil. Não é de se estranhar, portanto, que por um lado os dramaturgos nacionais tentem constituir um repertório brasileiro para ele - na quase totalidade das vezes, em vão, o que desencorajou muitos dos nossos escritores a continuar a produzir textos dramáticos - e também, por outro lado, que algumas referências ao ator e a seus papéis sejam feitas em outros textos. O domínio de João Caetano no palco do teatro São Pedro no Rio de Janeiro era tamanho que as referências seriam claramente compreendidas pela platéia da época. Assim, é natural que encontremos vários textos que se ligam a seu principal sucesso, o papel de Othelo na tragédia de Ducis.

Joaquim Manoel de Macedo (1820-1882) se remeteria ao tema do mouro de Veneza, ao Ihe dedicar, em 1856 (primeira publicação segundo a edição utilizada), O Novo Othelo, comédia curta em um ato encenada com sucesso, de acordo com Décio de Almeida Prado, em 1860213.

Na peça, Calisto, um negociante de armarinho que se dedica também à atividade dramática, passa por uma crise de ciúme na vida real ao procurar uma situação similar à do papel de Othelo, que representará dali a três dias. A cena se passa na casa de Antonio, um procurador que está saindo para o júri quando chega Calisto, noivo de sua filha Francisca. Animado com a peça que está ensaiando, ele fala de sua experiência:

\footnotetext{
"(Antonio e Calisto que entra e pára teatralmente diante de Antonio, imitando a entrada de Othelo no primeiro ato.)

ANTONIO - Então que é isto?... Continuamos com a mania teatral? (...)

CALISTO - Eu me calo, Odalberto, eu não respondo;

Um jus tendes assás de confundir-me;

Mas se já quando fui amigo vosso.
} 
Confesse, confesse, Sr. Antonio, que esta entrada é sublime! E diabo me leve se não fico dez furos acima do João Caetano.

ANTONIO - Mas o Sr. agora não se ocupa de outra cousa.

CALISTO - Que quer?... Aquele teatrinho particular da sociedade reveladora dos grandes talentos acendeu-me na cabeça uma fornalha. (...) Agora não penso, não cuido, não vivo senão em Othelo, cuja parte desempenharei daqui a três dias. Que emoções! Que entusiasmo! Os camarotes cheios de moças bonitas... A platéia atopetada de povo... Enchente real... Pode-se contar com ele mesmo porque não se compram bilhetes. A orquestra executa a ouverture. (Toca arremedando a música.) Já estão quase no fim... Gente fora da cena! Contra-regras a seus lugares! (Arremeda a música.) Fim!... (Assobia.) Lá vai o pano acima... Eis o senado de Veneza. (arranja o sofá e cadeiras como lhe parece.) Faça de conta que o Sr. é o senado de Veneza... Ande... Sente-se em todas estas cadeiras. Fala Moncenigo... Faça também de conta que o Sr. é Moncenigo: é um estúpido que há de enterrar o papel; mas não faz mal.

ANTONIO - Quem é estúpido, Sr. Calisto, quem é estúpido?

CALISTO - É o Manoelzinho lá da sociedade, homem; mas não me atrapalhe. Agora entra Odalberto... Faça ainda de conta que o Sr. é Odalberto... Entre por ali.

ANTONIO - Então eu sou tanta cousa ao mesmo tempo?

CALISTO - Não faz mal; está no sistema de acumulação de empregos. Entrou... Entende?... O Sr. entrou e ninguém lhe deu importância. Agora eu. Othelo vai aparecer: apenas me puser os olhos em cima, torça o nariz, faça uma cara muito feia, e sem se importar com as palmas e os aplausos com que o público me recebe, exclame com voz rouca e reconcentrado furor "ei-lo presente"! Não se descuide... Eu vou romper do bastidor... Sentido? (Vai entrar como Othelo.) Então... Sr. Antonio, não me esfrie a cena! Não me esfrie a cena, Sr. Antonio! Não se importe com os aplausos do público... Fale homem!... Com trezentos diabos diga "ei-lo presente"! ANTONIO - Meu amigo, o Sr. não vai bem do juízo: lembre-se, meu caro Sr. Calisto...

CALISTO - Eu já não sou Calisto, sou Othelo, o Mouro de Veneza.

${ }^{213}$ Há certa discrepância em relação à data da obra. A. Candido e S. Magaldi afirmam que a peça é de 1860; Mário Cacciaglia oscila entre este ano e 1863, data também indicada na edição consultada de $A$ Moreninha; Faria indica a encenação original em 1861. 
ANTONIO - Mas repare que não estamos no teatro." ${ }^{214}$

A longa citação se justifica pela abundância de referências que dela podemos extrair. Além de colocar em palavras a experiência de estar no teatro na época, descrevendo a platéia e a orquestra, a reação do público, etc., Macedo se remete diretamente a João Caetano e também ao texto de Ducis, ao nomear personagens como Odalberto, pai de Hedelmonda, e Moncenigo, o doge de Veneza (na obra original de Shakespeare, respectivamente Brabâncio e o Duque de Veneza). Mais do que isso, temos aqui a primeira citação tirada diretamente da peça francesa, seguindo a tradução de Gonçalves de Magalhães, na qual a primeira fala do protagonista (ao ser acusado pelo pai de sua amada perante o senado de Veneza) se inicia da mesma forma:

"OTHELO - Eu me calo, Odalberto, eu não respondo;

Um jus tendes assás de confundir-me.

Mas si já, quando fui amigo vosso,

A terra em que nasci não me era um crime,

Eu vos rogo que agora em minha fronte

Meus remorsos vejais, não vossa injúria."215

É interessante perceber que a tradução definitiva de Magalhães só seria editada em 1865, mas outras impressões já eram correntes desde 1842, segundo o próprio tradutor ${ }^{216}$. Isso sem falar nas inúmeras representações da peça, já que a tradução fora encomendada pelo próprio João Caetano. Aqui se inicia um procedimento recorrente em O Novo Othelo, que é o de Calisto repetidamente tornar suas as palavras da peça que está ensaiando, citando ipsis litteris a tradução de Magalhães em 27 ocasiões (vide o texto completo da peça de Macedo e os trechos relativos às citações no original de Ducis no Anexo 1) - afora diferenças relativas a rubricas e algumas mudanças de pontuação, Macedo mantém-se quase absolutamente fiel à edição de Magalhães.

\footnotetext{
${ }^{214}$ MACEDO, Joaquim Manoel. "O Novo Othelo", in Teatro da Juventude - Ano 4 - no. 20. São Paulo, Secretaria de Cultura, outubro/1998, pp. 95-96

${ }^{215}$ MAGALHÃES, D.J.G. Op. Cit., p. 262.

${ }^{216}$ Id. Ibid., p. 255.
} 
Retornando à peça de Macedo, Calisto continua falando de seu júbilo em representar a peça, e de como tal experiência tem influenciado seu cotidiano:

\begin{abstract}
"CALISTO - (...) eu reconheço que já não sei a quantas anda o meu armarinho: já não como, e já não durmo sossegado. Há dias em que chega-me um freguês, pede-me cartas de jogar, e eu dou-lhe soldados de chumbo; vem outro que pede tesouras, e eu dou-lhe obreas, vem um terceiro que quer comprar agulhas, e eu lhe apresento correntes de papagaio. À mesa do jantar encontro às vezes a imagem de Pézaro em um pedaço de carne seca, e a de Hedelmonda num prato de arroz de leite. De noite a cena é tremenda e horrorosa: acordo espantado, envolvido no meu lençol, e acabo sempre por assassinar Heldemonda, dando com uma vela de sebo mil punhaladas no travesseiro! Oh!"217
\end{abstract}

Antonio preocupa-se com o interesse quase obsessivo do provável futuro genro pela personagem, e aconselha o amigo a cuidar mais de seu armarinho. Ameaça não Ihe dar a mão da filha Chiquinha em casamento se ele passar a ser um "gênio sem vintém". Calisto continua a citar Ducis, e Antonio se retira. $O$ primeiro fica à espera de Chiquinha, sua amada, e imagina como seria tê-la no papel de Hedelmonda. Refletindo sobre as relações entre amor e ciúme, resolve esconder-se e ouvir a conversa de Francisca com a vizinha, Justina, em busca de um motivo de ciúme na vida real para melhor caracterizar Othelo no teatro.

As duas moças entram, e Chiquinha fala do amor que sente por alguém que não é Calisto. Sem jamais nomear o amado, vai falando de seus sentimentos, para exaspero do pretendente, que está embaixo da mesa. Este continua citando trechos da peça que vai representar, até se enfurecer a tal ponto que diz:

${ }^{217}$ MACEDO, Joaquim Manoel de. Op. Cit., p. 97. 
"CALISTO (à parte) - E eu então que papel farei nesta tragédia doméstica?... Sinto-me furioso... Até já nem me lembra pedaço algum da parte de Othelo." 218

Logo depois, porém, volta a citar o texto de Ducis, que se presta muito bem à situação. Enquanto isso, Francisca comenta que poderá até se casar com Calisto, mas continuará amando esse outro ser misterioso. A tensão vai aumentando até a moça dizer à amiga que, a fim de que o pai não a visse com o amado, ela o escondera em seu leito. Ao dirigir-se para a alcova, Calisto aparece e acusa Chiquinha, usando-se ainda das falas de Othelo.

Francisca parece divertir-se, e dá a Calisto a chave da alcova. Ao invés de entrar, porém, ele resolve primeiro ir ao armarinho, buscar "o punhal de Othelo" (expressão que ele repete insistentemente, mas que não está na edição de Magalhães). Ao mesmo tempo, Antonio retorna, e as moças tentam disfarçar. Calisto, meio fora de si, quer sair arrastando Justina, a quem chama de Pezaro. Antonio estranha a atitude do outro e o adverte, o que o faz sair sozinho em busca do punhal. Em uma breve saída de Antonio de cena, as duas amigas conversam, e a dubiedade permanece. Francisca comenta que esse seu noivo é um tolo, e por isso já tem outro em vista. Vai espiar o seu "querido" pelo buraco da fechadura e é surpreendida pelo pai. Calisto retorna, com um enorme punhal na cintura, mas ninguém o leva a sério:

\footnotetext{
"ANTONIO - Oh! Que cara de algoz!...

JUSTINA - Misericórdia!...

FRANCISCA (à parte) - O maníaco vai pôr tudo em pratos limpos.

CALISTO (a Francisca) - Preparai-vos.

FRANCISCA - Preparar-me para quê Sr.?...

CALISTO (a Francisca) - Então que diabos é isto?

ANTONIO (a Calisto) - Vossas preces a Deus hoje fizestes?

CALISTO (à parte) - Ora que este maldito estúpido teime sempre em esfriar-me as cenas!...."219
}

\footnotetext{
${ }^{218}$ Id. Ibid., p. 100.

${ }^{219}$ Id. Ibid., p. 104.
} 
Calisto está representando uma cena, é claro (o próprio "Preparai-vos!" vem de Magalhães), e a fala de Antonio vem reforçar isso, pois também é uma citação do texto de Ducis. Ou seja, ele já está ridicularizando Calisto com suas próprias armas, convidando-o a continuar a encenação ao "soprar-lhe" a continuação da fala de Othelo. Mas este, seriíssimo, entrega a Antonio a chave da alcova dizendo que ali se esconde um namorado de Chiquinha. O pai da moça se inquieta, e ordena a abertura do quarto. Francisca se desespera com a ira do pai, mas Calisto sai da alcova carregando um cachorrinho, o querido de Francisca. Mais calmo, Francisco permite à filha que brinque com o animal, e pede explicações a Calisto. Chiquinha despreza o noivo, e dramaticamente ele finge que se mata, após o monólogo final de Othelo. Os outros se riem dele, que sai correndo ao soar o meio-dia: está atrasado para o ensaio geral da peça.

Como podemos perceber, após a revelação do engano, a saída de Calisto não fecha bem o enredo. O final é, assim, um tanto quanto decepcionante, A peça tem, pois, vários altos e baixos: um engano frágil, algumas boas situações cômicas, mas nada muito pretensioso - é uma obra apenas para divertir. Isso é apontado por vários críticos que, no geral, fazem ressalvas ao texto. Um exemplo é Cacciaglia:

"De 1860 é também O Novo Otelo, farsa no estilo de Martins Pena (que havia satirizado os fanáticos pela ópera italiana). O protagonista é um rapaz sonhador, Calixto (sic), a tal ponto influenciado por João Caetano no papel de Otelo que chegava a identificar-se comicamente com se herói teatral. A peça não tem a ambição de ir além de um leve divertissement."220

Sábato Magaldi é ainda mais incisivo:

"Faltando o apoio da audiência, o simples Dr. Macedo foi buscá-lo nos assuntos já gastos, mas de eficácia comprovada: vieram, no drama, Luxo e Vaidade, em 1860, e Lusbela, em 1862. O severo crítico Machado de Assis, ao examinar com agudeza a obra de Macedo, verberou a 
concessão, apontando a fragilidade dos recursos melodramáticos, aos quais passaram a corresponder, em definitivo, nas comédias daqueles anos - O Novo Otelo (1860) e A Torre em Concurso (1861) -, os processos burlescos, distantes de uma ambição artística mais elevada. (...) Entretenimento inconseqüente, O Novo Otelo satiriza a mistura da realidade com a fantasia, uma influência da moda: Calisto, que vai representar o herói shakespeariano (sic), sente-se mais inflamado que ele. Cai no ridículo, quando verifica que o tesouro que a amada guardava na cama, e que ao pai aborrece, é um simples cachorrinho... O ato cômico tem fronteiras com a anedota, não visa senão a brincar com um tema do dia"221

Apesar de ser pouco citada entre os estudiosos, a obra O Novo Othelo é uma peça que suscita uma série de reflexões sobre o fazer teatral no Brasil no século XIX.

O primeiro ponto, já citado, é o testemunho do funcionamento do teatro no período, com as alusões feitas por Calisto. Mas esse não é o único ponto de interesse do texto de Macedo.

Por exemplo, além das citações, a estrutura da peça tem várias semelhanças com o texto de Ducis em termos de situação, como a vazão do ciúme e a revelação do engano. Entretanto, é interessante perceber que o eixo central da busca da prova de traição é um procedimento que não está em Ducis, mas sim no texto de Shakespeare: Othello se convence ao ouvir um diálogo que é mal interpretado. No original, Othello escuta lago e Cássio falarem sobre Bianca, e acha que falam de Desdêmona; em Macedo, Calisto não percebe que as moças falam de um cachorrinho, e não de um homem. Seria uma coincidência? Talvez, mas não custa lembrar que, no período em que a peça foi escrita, muitas pessoas já tinham acesso ao original de Shakespeare - podemos inclusive citar Gonçalves Dias, conhecido de Macedo. Além disso, se encenações da peça em si ainda não haviam ocorrido no Rio de Janeiro, no

${ }^{220}$ CACCIAGLiA, Mário. Pequena História do Teatro no Brasil: Quatro Séculos de Teatro no Brasil. São Paulo, T.A. Queiroz / EDUSP, 1986, p.59. 
mínimo a ópera Otello, de Rossini, já fora representada, como atesta uma crítica de José de Alencar de $1855^{222}$.

Mais um dado interessante é o processo de Calisto para entrar no papel de Othelo: primeiro, ele elenca indicações cênicas, depois tenta convencer Antonio a encenar a situação, e então, pouco a pouco, vai entrando na personagem, até valer-se quase que exclusivamente de suas falas. Em um dado momento, ele até toma para si uma fala de Pézaro ("Oh! Desgraçado Othelo!..."223). Além disso, Calisto dá como desculpa para seu furor o seu "gênio", uma noção tipicamente romântica e que coaduna com o tipo de interpretação de João Caetano (mesmo para tragédias neoclássicas), e só volta razoavelmente a si no final, ao fingir que se mata (afinal, é aí que acaba a peça de Ducis), apenas para sair correndo para o ensaio geral.

Outro ponto que merece uma investigação mais aprofundada é a ocorrência de citações em verso que não estão no texto original de Ducis, incluindo a fala que se torna um bordão obsessivo de Calisto: "O punhal de Othelo!" A expressão se repete em vários trechos:
"CALISTO (empunhando o punhal) - Ah!
O punhal de Othelo!... O punhal de Othelo!...
Eu mesmo, à minha escolha,
Quero dar-Ihe um suplício, quero vê-lo
Sofrendo, inanimado e apresentá-lo
Ensangüentado aos olhos que o encantaram."224

E, depois, se combina em verso com outro trecho ausente na obra de Ducis:

"CALISTO - Pois bem! Terás a seus

O meu cadáver: o punhal de Othelo!...."225

\footnotetext{
${ }^{221}$ MAGALDI, Sábato. Panorama do Teatro Brasileiro. $3^{\text {a }}$ ed. revista e ampliada. São Paulo, Global, 1997 , pp. 81 e 85.

${ }^{222}$ Vide FREIXIEIRO, Fábio. Alencar, os Bastidores e a Posteridade. Rio de Janeiro, Museu Histórico Nacional, 1977, p. 133.

${ }^{223}$ MACEDO, Joaquim Manoel de. Op. Cit., p. 99. Na peça de Ducis, o trecho está em MAGALHÃES, D.J.G. Op. Cit, p. 333.

${ }^{224}$ MACEDO, Joaquim Manoel de. Op. Cit., pp. 104-105.
} 
De onde Macedo tira tais citações, ou será que ele mesmo as inventa? Uma possibilidade para explicar tais elementos no texto de Macedo seria a do autor ter-se valido de alterações promovidas no texto no processo de encenação, da apreensão de "cacos" introduzidos por João Caetano durante sua representação, por exemplo. Não dispomos de documentação suficiente que ateste tais "cacos", ou mesmo qualquer outro tipo de modificação do texto original francês, a não ser o monólogo final, como já explicado. Seria interessante descobrir se Macedo teve outras fontes, ou se ele mesmo produziu algumas dessas falas em verso. Sem dúvida, um campo aberto para a pesquisa.

Como podemos perceber, apesar de certos defeitos estruturais e da pouca ambição enquanto obra, O Novo Othelo é uma peça que promove um bom número de informações e reflexões sobre a cena dramática no Brasil no século $\mathrm{XIX}$, especialmente em um período de transição entre o Romantismo e 0 Realismo (no teatro). Ao ridicularizar os excessos do ciúme de Calisto - e, por extensão, citando os excessos interpretativos de João Caetano e os excessos lingüísticos de Ducis - Macedo traça um retrato das forças contrastantes na época (e, não custa lembrar, em sua própria obra), valendo-se para isso da forma da comédia curta.

Por outro lado, ainda que haja uma motivação cômica em todas as citações e referências a João Caetano e sua encenação do Othelo duciano, podemos encarar todo o entrecho como uma grande homenagem ao ator carioca e seu desempenho como mouro de Veneza, que Calisto tanto parece admirar e querer imitar. Como afirma Arêas,

"A afirmação de Calisto, personagem de O Novo Othelo, de que a sua interpretação do Mouro ficava 'dez furos acima do João Caetano', quando vemos essa mesma personagem mergulhada na própria mediocridade e

${ }^{225}$ Id. Ibid., p. 105 
falta de discernimento, produz o efeito oposto, o de preservar a glória do nosso trágico". ${ }^{226}$

Ressalte-se, novamente, a importância da encenação de João Caetano, para chegar a incitar uma nova peça sobre a mesma, e a diferença de tom em relação à crítica ao estilo do ator carioca que fizera Martins Pena.

Também é bom ressaltar que, apesar da crença de que O Novo Othelo teve apenas algumas poucas representações no início da década de 1860 e em 1870, há a notícia de pelo menos mais uma encenação no Rio de Janeiro no século XIX. O periódico A Vida Fluminense indica, em maio de 1871, tratando de um espetáculo dedicado ao recém-chegado Ernesto Rossi:

"Constou o espetáculo das comédias brasileiras O Novo Othelo, O Tipo Brasileiro e O Fechamento das Portas.

"No desempenho de três papéis de gêneros tão diferentes houve-se o Vasques com o talento que todos Ihe conhecem, conseguindo no Novo Othelo imitar com muita felicidade diversas inflexões e gestos trágicos do incomparável Rossi, principalmente no final da comédia, quando caricaturou a morte do ciumento mouro.

"O próprio Rossi riu a bandeiras despregadas!"227

O comentário dá margem à pergunta: quais ajustes foram feitos ao texto para a encenação? Se Vasques esmerou-se em copiar Rossi, e não João Caetano, teriam as citações do Otelo de Ducis sido substituídas por trechos da versão utilizada por Rossi, a shakespeariana? Parece razoável supor que sim.

O próprio Ernesto Rossi, em sua autobiografia, relembra o espetáculo e as pessoas que conhecera na ocasião:

\footnotetext{
${ }^{226}$ ARÊAS, Vilma Sant'Anna. Op. Cit., p. 256

${ }^{227}$ A Vida Fluminense, ano 4, no. 177, 20/05/1871, p. 578.
} 
"Não posso esquecer-me, dentre eles, Furtado Coelho, Maria Adelaide e um certo Vasques, ator cômico, nascido no Rio, pleno de belas qualidades naturais e artísticas, o qual, sem nenhum modelo a quem imitar, estava pronto a apresentar um tipo de comicidade e bufoneria tal, que era de fazer arrebentar de rir, sem jamais recorrer ao trivial ou ao baixo". 228

Infelizmente, Rossi nada diz sobre a imitação que Vasques fizera de si, deixando-nos, pois, apenas com hipóteses sobre possíveis mudanças no texto de O Novo Othelo.

${ }^{228}$ ROSSI, Ernesto. Quarant'Anni di Vita Artistica, volume Terzo. Firenze, Tip. Ed. Di L. Niccolai, 1889, p. 57. 


\subsection{4 - ALUÍSIO AZEVEDO E EMÍLIO ROUĖDE: O CABOCLO}

Apesar de ser reconhecido como o mais importante romancista brasileiro ligado ao Naturalismo, com obras como O Mulato e Casa de Pensão, pouco se fala hoje em dia sobre a produção de Aluísio Azevedo (1857-1913) para o teatro. Contudo, além de uma colaboração frutífera com o irmão, o comediógrafo Artur Azevedo, Aluísio teria carreira solo como dramaturgo, e também assinaria seis peças em parceria com Emílio Rouède (1850-1908), pintor e literato francês radicado no Rio de Janeiro.

É importante ressaltar que costuma-se estudar pouco as tentativas naturalistas no teatro brasileiro. Em uma época na qual o domínio da burleta e dos gêneros mais populares foi incontestável, o drama naturalista não encontrou espaço para florescer mais amplamente. Isso não quer dizer que esforços não tenham sido feitos, o que pode ser comprovado pela encenação de adaptações de romances de Émile Zola como Therèse Raquin e Nana, entre 1880 e 1881. Entre dramaturgos brasileiros, o primeiro sopro naturalista viria justamente de Aluísio Azevedo, que, como Zola, resolveu adaptar um de seus romances para a cena: O Mulato estreou em 1884, no Rio de Janeiro. Em retrospecto, Adolfo Caminha afirmaria depois, em 1895:

"Ainda está na memória do público fluminense o brilhante sucesso que obteve o notável drama de Aluísio Azevedo - O Mulato.

O teatro encheu-se completamente, o público aplaudiu a obra com desusado entusiasmo; e é preciso não esquecer que tratava-se de uma obra naturalista, gênero com que ainda não estávamos habituados. A imprensa, em sua quase totalidade, teve francos elogios para o jovem romancista que, num rasgo de patriotismo audacioso, tentara reformar o teatro no Brasil fazendo representar um drama de costumes nacionais, verdadeiro e bem arquitetado.

Não durou muito o entusiasmo, é certo. A peça foi levada à cena meia dúzia de vezes e, como sucede sempre, caiu sendo logo substituída pelo Conde de Monte Cristo, melhor fonte de renda para os empresários". 229

${ }^{229}$ CAMINHA, Adolfo. "Pseudo-teatro", in FARIA, João Roberto. Idéias Teatrais: o Século XIX no Brasil. São Paulo, Perspectiva / FAPESP, 2001, p. 631. 
Mas Aluísio Azevedo não desistiria. Com o amigo Emílio Rouède, que conhecera no início da década de 1880 . Aluísio voltaria a uma tentativa de drama naturalista com O Caboclo, em 1886.

O drama em três atos estreou no Teatro Santana, no Rio de Janeiro, em seis de abril de 1886, tendo o famoso ator cômico Vasques no papel principal, ansioso por mostrar ao público e à crítica seu valor também em papéis dramáticos. A tarefa não era pequena: um papel que envolvia declamações do Otelo, cenas de tristeza e violência, e ações realistas.

A ação da peça se passa em uma fábrica de cigarros no Rio de Janeiro, pertencente a Virgílio Gonçalves Dias, um apaixonado pelo teatro que prefere ver seus empregados ensaiarem as peças que ele escreve a vê-los trabalhando - o que muito irrita sua esposa, D. Quitéria.

O primeiro ato mostra o escritório da fábrica. Luís, o caboclo que fora criado por Virgílio, discute com sua esposa Luísa - também criada na casa do chefe e com Flávio, um outro trabalhador. O debate é pelo fato de Luís adorar o teatro e pela mulher sempre rir dele atuando. Ela o considera engraçado e faz um comentário que não deve ter passado despercebido para a platéia da estréia da peça:

"LUÍSA - Não serves para o drama, repito! Tua cara, teus gestos, tua voz não têm nada de dramático! Eu até te acho parecido com o Vasques!"230

A afirmação, logo no início da peça, faz uma mescla interessante entre a personagem, que pretende provar seu valor dramático, e o ator que a interpretava, já que Vasques também queria demonstrar seu potencial em um gênero que não era o seu. A réplica da personagem já traz a primeira citação do Otelo, que perpassará todo o texto:

\footnotetext{
${ }^{230}$ FARIA, João Roberto (org.). Teatro de Aluísio Azevedo e Emílio Rouède. São Paulo, Martins Fontes, 2002, p. 164.
} 
"CABOCLO - Pois hei de provar-te que sou capaz de representar o drama tão bem como os outros! Hás de ver quando eu disser: (declama)

'Oh, nunca, lago, não mais!

À semelhança do Pôntico,

Cujas correntes jamais

Refluem; e vão a Propôntico

Pagar tributo, e ao Helesponto,

Assim os meus pensamentos

Não podem voltar ao ponto

Donde partiram, violentos!'

(suspende porque os dois estão rindo) E não é que estão rindo ambos! Ora esta!"231

Talvez a reação do público a Vasques não fosse esta, mas o pequeno episódio, casado perfeitamente ao enredo da peça, poderia ter servido inclusive para advertir o público do trabalho que o ator pretendia empreender ao longo da apresentação, pedindo assim atenção e paciência para aguardar o que viria.

Flávio defende o Caboclo, que conta também com a confiança do patrão. Ele diz a Luís que o importante é agradarem a patroa fazendo cigarros e Virgílio representando o que ele escreve. Luís afirma, irritado:

"CABOCLO - Amanhã é que eu quero ver se ela tem vontade de rir, quando eu aparecer vestido de mouro, de Otelo, com a minha capa e a minha espada!"232

É uma afirmação mais verdadeira do que as personagens imaginam no momento. A discussão arrefece e o Caboclo sai para recolher fumo, tarefa de sua esposa.

Deixados a sós, Flávio e Luísa revelam seu envolvimento amoroso. O rapaz afirma que várias pessoas da fábrica já suspeitam do caso, e teme a

\footnotetext{
${ }^{231}$ Id. Ibid., p. 164.

${ }^{232}$ Id. Ibid., p. 165.
} 
desconfiança de Luís e seu gênio; Luísa faz pouco da reação que o marido teria. As declarações de amor dos dois são interrompidas por Virgílio, que acha que eles estão ensaiando sua nova peça, e começa a corrigir-lhes as falas.

Na cena seguinte, D. Quitéria vem reclamar que na fábrica ninguém trabalha, pois todos só pensam em teatro (a começar pelo chefe), o que só deveria acontecer no domingo. Seu marido argumenta que, chamando-se Virgílio Gonçalves Dias, só poderia ser poeta, e defende-se. A esposa manda que ele vá trabalhar, assim como Luísa. Quitéria reclama com Flávio que o Caboclo faz o trabalho da esposa, que sempre tenta escapar do trabalho. Percebendo que o empregado também está parado, ela ordena-lhe que vá ocupar-se também. Luís entra com maços de fumo e a patroa reclama que ele abusa de sua condição de afilhado de Virgílio. Luís afirma que estava trabalhando, mas D. Quitéria o proíbe de fazer o trabalho de Luísa. Ele se põe a enrolar cigarros.

Na cena VII, o empresário Domingos e seu companheiro Gomes surgem e dizem a D. Quitéria que querem tratar com o Sr. Virgílio sobre o teatro nacional. Ela sai, e o Caboclo conversa com os visitantes. Diz que Virgílio é seu padrinho, e que é o primeiro galã da companhia dramática da fábrica, sendo sua esposa a primeira dama. Domingos demonstra interesse e pergunta sobre o repertório do grupo: "CABOCLO - Agora mesmo, temos em estudo três ricos dramas, em cinco
atos cada um.

GOMES - Três vezes cinco, quinze! Quinze atos!

DOMINGOS - E originais todos?

CABOCLO - Tudo o que há de mais original! Um é tirado de uma peça grega; outro é de 'Petrarqua', e o outro é o Otelo.

DOMINGOS - De Shakespeare?

CABOCLO - É, uma coisa assim, pouco mais ou menos.

GOMES - E o Sr. Gonçalves Dias escreveu o Otelo?

CABOCLO - Se escreveu? Todinho! Desde o primeiro ato até o último!

DOMINGOS - Mas o mesmo Otelo?

CABOCLO - Ora essa! O que há de mais Otelo. Não lhe falta uma vírgula! 
DOMINGOS - Ah, bravo! Já vejo então que o senhor seu padrinho é homem instruído! Pelo menos, há de conhecer profundamente a literatura inglesa, e os clássicos gregos, e os italianos!...

CABOCLO - Ora, se assim fosse que admiração! Mas o melhor é que ele só sabe um bocadinho de francês e outro bocadinho de português, mais nada!"233

O diálogo revela a relativa ignorância do Caboclo ao mesmo tempo em que evidencia as origens do Otelo. Como discutiremos posteriormente, porém, a adaptação de Virgílio é primorosamente fiel ao original shakespeariano, o que não pressuporíamos a partir do diálogo supracitado.

Como o patrão demora a aparecer, Luís vai chamá-lo, intuindo que D. Quitéria não lhe dera o recado. Deixados a sós, Domingos e Gomes demonstram estar, na verdade, preparando um golpe para o crédulo Virgílio. Este surge com Luís, o qual vai sentar-se à sua mesa para pretensamente trabalhar. Virgílio, Domingos e Gomes falam sobre a situação do teatro nacional, que requer uma revitalização, e apresenta a sua idéia:

\begin{abstract}
"DOMINGOS - (...) Para consegui-lo, lembrei-me de criar uma empresa, garantida por um limitado número de ações de valor de cem mil réis cada uma, comprometendo-me eu ainda, a montar as peças dos meus acionistas. Assim pois, mediante a insignificância de cem mil réis, terá quem quiser, nem só teatro por um ano, como ainda a glória de ver as suas peças representadas por uma companhia de primeira ordem e, o que é melhor, seu nome entre os dos fundadores do teatro nacional."234
\end{abstract}

Virgílio e Luís se entusiasmam; Domingos, porém, afirma que primeiro precisa conhecer a qualidade das peças, ao que Virgílio Ihe propõe a leitura de seu último drama, e emenda:

"VIRGÍLIO (levantando-se) - Porque não sei se sabem, os senhores hoje não me saem daqui. Amanhã é domingo, faço representar no meu teatro a

\footnotetext{
${ }^{233}$ Id. Ibid., pp. 183-185.

${ }^{234}$ Id. Ibid., pp. 191-192.
} 
primeira do meu Otelo e exijo a presença de ambos. (indo ter com o Caboclo) Vai a meu gabinete e traze-me o maço de meus dramas. Manda vir cerveja e copos. (Caboclo sai. Aos outros dois indicando a porta por onde saiu o (aboclo) Também tem muito gosto pelo teatro... É um caboclo que recolhi em pequeno! Bom rapaz, honesto, trabalhador e valente com as armas! Não entra neste drama que lhes vou ler!

DOMINGOS - O grego?

VIRGÍLIO - Sim, mas entra no Otelo. Ah! O Otelo! Os senhores vão ver amanhã o que é o meu Otelo!

DOMINGOS - Mas o seu Otelo tem alguma coisa com o do Shakespeare?

VIRGÍLIO - Ah! Foi tirado de uma tradução francesa.

DOMINGOS - É original!

VIRGílIO - É, pois entendo que com o mesmo sans-façon que certos autores vão buscar os seus assuntos na vida real, posso eu ir buscá-los num livro, seja lá de quem for! Creio que não deixo de ser menos original por isso?"235

Aqui ficamos sabendo, pois, da iminente estréia da adaptação do Otelo, com o Caboclo por protagonista; quanto à fonte da obra de Virgílio, "uma tradução francesa", devemos ressaltar que todas as citações de Otelo no texto do drama de Azevedo e Rouède são traduções muito bem cuidadas do texto de Shakespeare, mas não seguem as regras das traduções francesas correntes no período. Em O Caboclo, os trechos da peça shakespeariana estão em verso, como a tradução de Vigny, que, entretanto, é menos fiel às palavras do original inglês; a fidelidade ao texto aproxima as citações na peça da tradução de François-Victor Hugo, que foi, contudo, feita em prosa no francês. A sugestão mais plausível é uma tradução direta e caprichosa do texto, do inglês para o português, feita pelos próprios autores, ainda que isso não coadune com a personagem de Virgílio - o que leva à afirmação de que sua versão viera de uma tradução francesa, uma língua mais acessível às capacidades da personagem no período retratado.

Voltando ao enredo, Virgílio tenta iniciar a leitura de seu drama grego, mas interrupções dos funcionários da fábrica o irritam e ele decide subir com os

${ }^{235}$ Id. Ibid., pp. 193-194. 
visitantes para seu gabinete, a fim de não serem importunados. Domingos e Gomes o seguem já sem muito entusiasmo.

O segundo ato ocorre na oficina da fábrica, onde os empregados estão, cada um em seu banquinho. Enquanto trabalham, eles cantarolam ou declamam à meia voz suas falas das peças. Flávio, Henrique, Manoel e João conversam e reclamam de D. Quitéria. Luísa toca a sineta para o almoço. Todos saem, menos a moça, pois Caboclo a retém, para mostrar-Ihe a capa de Otelo:

\author{
"CABOCLO - Olha! Enquanto vão comer, vê lá isto! (tira da trouxa uma \\ capa à Otelo que põe nos ombros. Sentindo-se entusiasmar com a capa, \\ declama e toma atitude trágica) \\ 'Mas por que não há de o louco, \\ Cinqüenta mil vidas ter? \\ Uma só é muito pouco...' \\ LUÍSA - (interrompendo-o) Ora, foi para isto? \\ CABOCLO - Não! Foi para mostrar-te isto. Não vês? Esta capa está mais \\ comprida de um lado que do outro. (inclina-se para um dos lados)"236
}

Podemos perceber como as citações de Otelo afloram no texto com freqüência, reforçando de certa forma a identificação do Caboclo com o papel. Em seguida, Luís também reclama da faixa que ele pedira para a esposa confeccionar, e que não ficara a seu gosto. Luísa fica irritada, e os dois discutem. Ele não admite que ela o trate tão mal. Quitéria entra e percebe a briga do casal. Ambos se queixam da implicância do outro. Contrariado, Luís acaba saindo. D. Quitéria passa um sermão em Luísa, e a aconselha:

"QUITÉRIA - Sim! Não é bom que estejas sempre em discórdia com teu marido! Todo caboclo é desconfiado e perigoso, com aquele deves ter muito mais cuidado do que terias com outro qualquer marido". ${ }^{237}$

Quitéria quer que Luísa controle seu gênio e que trate o Caboclo como trata os outros. Luísa deixa escapar que acha que Quitéria está se referindo a Flávio,

\footnotetext{
${ }^{236}$ Id. Ibid., pp. 202-203.

${ }^{237}$ Id. Ibid., p. 210.
} 
mas Quitéria estranha o fato da moça citar o nome dele. Quando Luísa sai para tocar a sineta novamente, D. Quitéria externa suas suspeitas e cogita demitir Flávio.

Os empregados voltam ao trabalho e a patroa pede a João que vigie os outros. Mal ela sai para se arrumar com Luísa, porém, Flávio pede a João que fique espiando na porta para que eles possam ensaiar. Ele comenta que "nem João Caetano" faria melhor sua cena amorosa com Luísa, o que suscita comentários dos colegas. Eles ensaiam o texto sobre Petrarca e Laura até João avisar que a patroa está voltando. Rapidamente, todos voltam ao trabalho. D. Quitéria anuncia que irá à cidade e chama Henrique para acompanhá-la. Ela também avisa a Luísa que Domingos e Gomes passarão a noite ali e devem ter quartos arrumados. Mal ela sai, o Caboclo vem anunciar que podem ensaiar. A cena merece ser citada pelo uso de Otelo como centro do ensaio:




Desta triste viuvez!

E tu, amor, deixa o cetro,

Despe o teu manto real;

Já não és rei, pobre espectro,

Cedeste o trono ao rival!

Em negro ódio danado

Tu abdicaste à coroa;

Nossa estrela, desgraçado,

Nuvem de sangue apagou-a!

Coração, incha, maldito,

Que de peçonha estás cheio!'

FLÁVIO - Calma! Calma!

CABOCLO - _E eu repito! Sangue! Sangue!'

FLÁVIO - Ah! Receio

Por vós, senhor: pode ser

Que, melhor pensando o ato

De Desdêmona, sobre o fato

Mudareis de parecer...'

CABOCLO -

'Ah! Nunca lago, não mais,

À semelhança do Pôntico

Cujas correntes jamais

Refluem; e vão a Propôntico

Pagar tributo, e ao Helesponto,

Assim os meus pensamentos

Não podem voltar ao ponto

Donde partiram, violentos!

Não voltarão mais ao casto

E humilde amor, mas terão

De servir de negro pasto

À vingança e à maldição!

(ajoelha-se solenemente)

Assim o juro e sustento

Por esta abóbada infinda

Que escuta meu juramento!'

FLÁVIO (ajoelhando-se também) -

'Não vos levanteis ainda!

Eu por testemunha tomo 


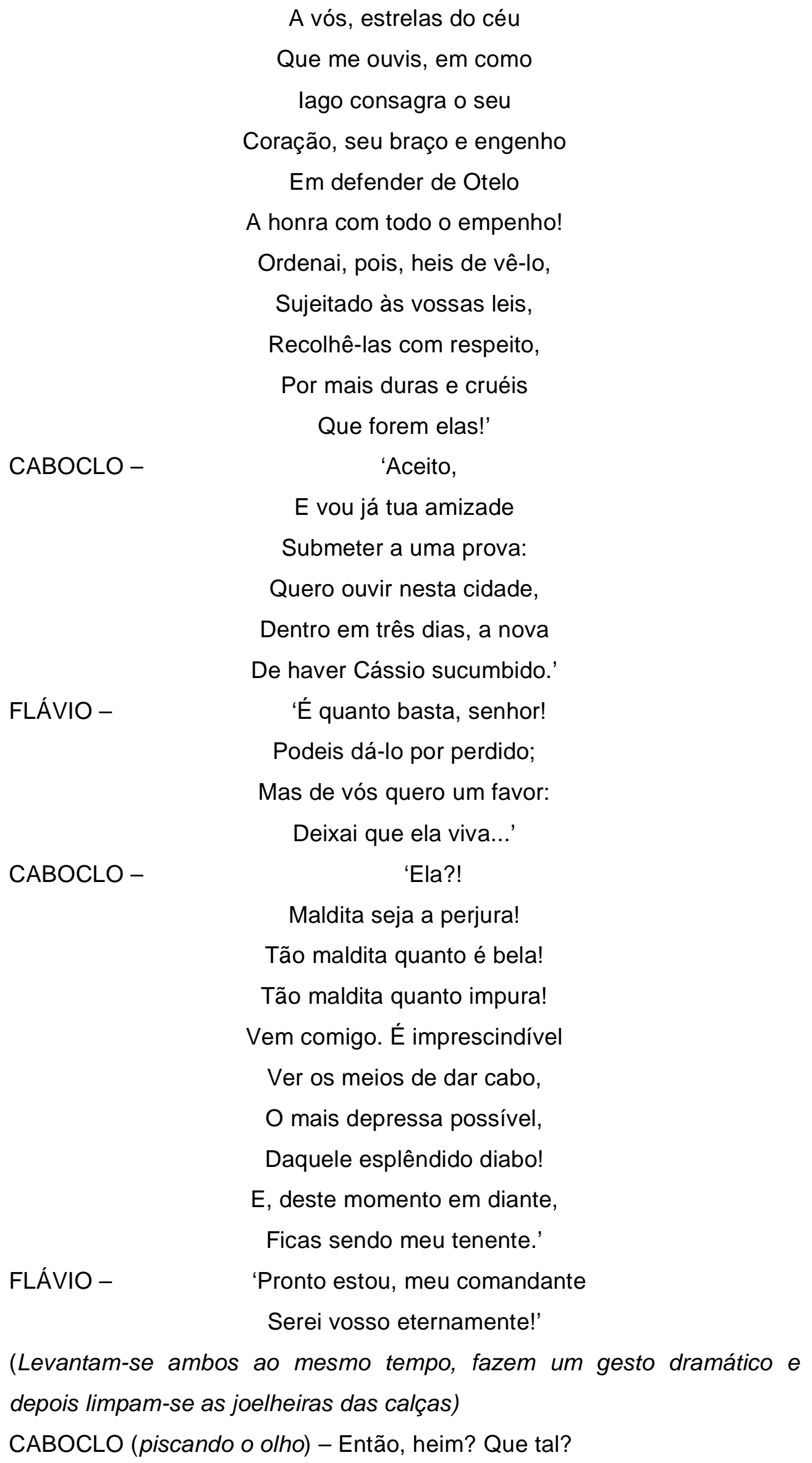


MANOEL (abraçando o Caboclo) - Esplêndido! Meu amigo! (indo apertar a mão de Flávio) Muito bem, muito bem!

CABOCLO - Isto ainda não é nada! Na cena da morte (faz que estrangula alguém) é que são elas!"238

É interessante pensar que Flávio faz o papel de lago, aquele que engana Otelo, e não o de Cássio, o pretenso amante de Desdêmona. Este fato não apenas faz com que a peça shakespeariana ecoe de alguma forma o que está acontecendo fora dela, na fábrica, ao mesmo tempo em que serve de mote para a forte interação das duas personagens no 'teatro dentro do teatro' instaurado na cena.

Logo a seguir, Virgílio aparece com Gomes e Domingos, e vê que os empregados estiveram ensaiando. Luís e Flávio se gabam de ter feito uma ótima cena. Virgílio comenta:

"VIRGÍLIO (a Domingos e Gomes) - Ensaiaram uma cena do meu Otelo; ah! Mas eu gosto mais do outro!

DOMINGOS - Do de Shakespeare?

VIRGílLIO - Não, filho, falo do meu outro drama, o meu Demócrito."239

Novamente temos a personagem Domingos retornando ao nome de Shakespeare, e novamente sem evolução, em uma passagem que já se torna cômica. Ele e Virgílio passam a falar do Demócrito. Domingos faz ressalvas à última cena, em que Demócrito apalpa o coração de Stratonícia e faz desfilar perante ela os moços da casa real, até que o peito dela palpita mais forte ao passar Nicanor, seu amado. Virgílio defende sua obra e resolve encená-la para demonstrar seu valor. Faz o Caboclo chamar Luísa e, na ausência de Henrique, pede ao próprio Caboclo que o substitua no papel de Demócrito. Luís põe-se a estudar a cena e não ouve as indicações de Virgílio aos outros, e assim não sabe que o papel de Nicanor é representado por João. Todos iniciam o ensaio, e quando Flávio passa por eles, o Caboclo dá a fala reservada à passagem de Nicanor. Todos riem, menos Virgílio, que reclama

\footnotetext{
${ }^{238}$ Id. Ibid., pp. 221-226.

${ }^{239}$ Id. Ibid., pp. 227-228.
} 
que aquela fala seria para quando João se aproximasse. Luís não entende, pois Luísa estremecera na passagem de Flávio. Os empregados riem e cochicham, e até confidenciam aos visitantes o porquê das gargalhadas. Gomes considera tudo "impagável, esplêndido", duas palavras que ficam ecoando na mente do Caboclo, que é deixado sozinho em cena. Finalmente, ele compreende a situação, e o pano cai.

O terceiro ato se passa em uma sala desarrumada, nos bastidores do teatrinho da fábrica, onde há figurinos, pedaços de cenários, como um colchão, e adereços. Só, o Caboclo está sentado, pensando. Ele chora. D. Quitéria entra e, ao vê-lo nesse estado, se aproxima e pergunta-Ihe o que o faz sofrer. Ela afirma conhecê-lo bem, pois o criou, e Luís finalmente explica sua desconfiança e o modo como os outros haviam rido dele. Quitéria pergunta se ele tem provas da traição de Luísa, e diz que sem isso ele não deve decidir fazer nada. Ao mesmo tempo, afirma que, se Luísa for culpada, quer vê-la castigada, do modo que o Caboclo achar conveniente. Ele não sabe como conseguir provas, então D. Quitéria aconselha-o a espreitar Luísa e Flávio, e é isso que Luís decide fazer. Ao ouvir vozes, ambos saem, e o Caboclo fica à espreita.

Virgílio entra com Domingos e Gomes, conversando sobre as peças do dono da fábrica e sobre o contrato para encená-las. Para que o Demócrito seja a primeira peça encenada no Conservatório, Virgílio prontifica-se a buscar o dinheiro das ações rapidamente. Eles se retiram. $\mathrm{O}$ Caboclo volta à cena $\mathrm{e}$ reflete, ecoando a personagem Otelo:

"CABOCLO - (...) Impagável?... Esplêndido? (pausa) Esplêndido. Estremecer Luísa, bater-Ihe o coração quando Flávio passava?... Esplêndido, por quê? (pausa) E por que riram?... aí estão as provas!... (pausa) Mas não; não é possível que ela me engane! Enganar-me por quê? Que Ihe fiz eu, para merecer-Ihe tamanha maldade?!... Não! Ela veria logo que semelhante coisa seria a minha desgraça, a minha perdição! Não, não pode ser! Aquele riso com certeza não era o que eu supus! Como se poderia acreditar que a minha Luísa que eu conheci deste tamanho, (estende o braço) tão inocente, tão meiga, tão pura, crescesse e ficasse 
mulher, só para enganar seu marido?... Não! Não é possível! Deus não a teria deixado viver para isso! Deus a teria chamado a si enquanto ela ainda era um dos seus anjos! (pausa. Reação) Mas então por que me olhavam daquele modo? Por que riam em torno de mim? Por que 'esplêndido'? Por que 'impagável'? E ele, o infame, por que ficou mais branco do que a cal da parede? Sim! Por quê? Se não tinha culpa? (pausa) Ela, a quem eu amava como a um Deus! Ele, que eu estimava e protegia como a um irmão! Por que haviam ambos de matar-me deste modo?! Matar-me sim porque, se me não provarem que enlouqueci, se a minha cisma não é de doido, eu não quero a vida para mais nada! Que me importa a verdade inteira se não posso sofrer mais do que já sofro agora!"240

O Caboclo ouve Luísa aproximar-se, e se esconde. Ela entra cantarolando, convence-se de que não há ninguém por perto e faz um sinal para fora. Flávio entra também. Ele pergunta à moça se ela estivera com Luís, se notara alguma desconfiança. Ela acha isso bobagem, mas Flávio está convicto de que o Caboclo tem suspeitas em relação aos dois, mas sabe disfarçar bem. Ela está tranqüila, mas sugere-Ihe que eles podem fugir. Flávio quer evitar isso, e diz a ela que observe o marido, enquanto ele disfarça o melhor possível. Saem um para cada lado, e, segundo a rubrica, Luís "sai de detrás do bastidor, completamente transformado notando-se-lhe uma idéia fixa e uma certa expressão de loucura" ${ }^{241}$. Ele vaga pela cena, até que Virgílio, acompanhado dos visitantes, vem chamá-lo para que vá se arrumar para a apresentação do Otelo aos hóspedes. Luís afirma que está com medo; os outros supõem que é por causa da apresentação, e dão diferentes conselhos, até que Domingos diz que o que Luís deve fazer é imaginar que tudo o que Otelo diz e faz é verdade, e que ele deve supor que sua mulher é realmente Desdêmona, e ele, Otelo. Virgílio vai arrumando o figurino do Caboclo e busca um punhal para atirar ao chão no último ato, após apagar a lâmpada e antes de matar Desdêmona. Luís ouve as explicações de Virgílio distraidamente e é deixado a sós, para repassar o papel rapidamente antes de entrar no palco. A cena seguinte traz a transformação de Luís em Otelo, deixando-nos sem saber mais o que é ensaio

\footnotetext{
${ }^{240}$ Id. Ibid., pp. 254-255.

${ }^{241}$ Id. Ibid., p. 260.
} 
e o que é real; as falas da personagem penetram no Caboclo e tornam-se suas:

“CABOCLO (só, depois de uma pausa) - Já não resta dúvida!... (pausa prolongada depois da qual recita como alucinado)

'Ah! Bem claro vejo agora!

Quero a vingança, por Deus!

Olha, lago, neste instante

De minha afeição mais doce

Apago a chama radiante.

Que o vento a leve. Apagou-se!

E agora, negra vingança,

Desperta por tua vez,

És a única esperança

Desta triste viuvez!

E tu, amor deixa o cetro,

Despe o teu manto real;

Já não és rei, pobre espectro,

Cedeste o trono ao rival!

Em negro ódio danado

Tu abdicaste à coroa;

Nossa estrela, desgraçado,

Nuvem de sangue apagou-a!

Coração, incha, maldito,

Que de peçonha estás cheio!'

LUÍSA (entrando) - Bravo! Muito bem! (admirando-o) Sim senhor! Estás esplêndido!

CABOCLO (sorrindo amargamente) - Esplêndido!!

LUÍSA - Mas que tens? Acho-te mudado!

CABOCLO - Parece-te? É natural! Não vês que agora eu sou Otelo?"242

A ironia da frase de Luís, calcada no seu duplo sentido, reflete perfeitamente a situação dupla da personagem do Caboclo no momento. Luísa tenta desanuviar o ambiente, e estranha uma certa rispidez no marido. Ele afirma

${ }^{242}$ Id. Ibid., pp. 264-265. 
estar tenso com a apresentação, e ela tenta abraçá-lo. Ele adoça seu tom, e ela vai arrumar-se. É um momento de hesitação de Luís, que sai pela direita.

Flávio vem à procura de Luísa, que está estranhando o comportamento do marido. Ela propõe a Flávio fugirem, mas ele reluta. Decidem finalmente encontrar-se lá fora durante a peça, e Luísa torna a fechar-se em seu camarim. Flávio é surpreendido por Luís, que o ameaça e lhe pergunta o que faria em seu lugar. O Caboclo ordena a Flávio que fuja, ou será morto por ele. Flávio escapa, jurando vingança.

Luísa entra, sem saber o que se passara:

"LUÍSA (vestida de Desdêmona, adianta-se dois passos em cena) Pronto!

CABOCLO - Ah! Chegas a tempo! (corre sobre ela e agarra-a) Entras agora em cena! Esperava-te, Desdêmona! Minha doce e fiel companheira! Casta ilusão de minha alma! Estrela de minha vida! Fizeste bem em vir! LUÍSA (retraindo-se) - Enlouqueceste?

CABOCLO - És minha! Não me escaparás!

LUÍSA - Acudam!

CABOCLO (fechando-Ihe a boca com a mão direita e conservando-a presa com a esquerda) - Não chames! Ninguém te acudirá! És minha! E hei de apagar tua vida, como se apaga a luz de uma lâmpada!

LUÍSA (conseguindo escapar-Ihe das mãos) - Socorro! (dá uma volta em cena perseguida pelo Caboclo) Flávio! (neste momento tropeça no colchão e cal)

CABOCLO (precipitando-se sobre ela e tomando-Ihe o pescoço com as mãos) - Ah! Miserável! É a morte que chamas! (sufoca-a. Depois rindo desvairado) Grita! Chama Flávio! Vê se ele te acode!"243

As outras personagens, menos Flávio, entram chamados pela gritaria. Falam ao mesmo tempo, tentando entender o que se passa. Virgílio vê Luísa no colchão:

${ }^{243}$ Id. Ibid., pp. 273-275. 
"VIRGÍLIO (...) - Morta! Que fizeste?!

CABOCLO (desvairado) - Fiz o drama! Não queriam drama?! Pois aqui o têm... Aplaudam! Vamos, aplaudam! (a Quitéria que se tem aproximado)

Eis as provas! (recitando)

'Neste instante

De minha afeição mais doce

Apago a chama radiante!'

QUITÉRIA Desgraçado. (vendo Luísa) Ela!

CABOCLO -

'Ela?

Maldita seja, a perjura!

Tão maldita quanto é bela!

Tão maldita quanto impura!'

(solta uma gargalhada e depois, completamente fora de si)

'Mas por que não há de o louco

Cinqüenta mil vidas ter,

Uma só é muito pouco!

E eu repito! Sangue! Sangue!'

(solta uma nova gargalhada) Impagável! Esplêndido! Aplaudam!

Aplaudam! Isto é o drama! (solta uma gargalhada mais nervosa e prolongada e cai desfalecido nos braços de todos os outros que correm para ampará-lo)"244

A identificação final de Luís com seu personagem é quase total, à exceção do suicídio. No fundo, ele enlouquece após uma paródia grotesca e real do quinto ato de Otelo, assassinando a esposa vestida de Desdêmona sobre um leito de mentira - um colchão de cenário -, estando ele próprio vestido de Otelo e retomando a famosa imagem da peça sobre apagar a lâmpada e depois a vida da amada. A seqüência, também similar à da obra shakespeariana, da chegada dos outros, apenas reforça o elo. Mas aqui Desdêmona não era inocente; nem seu Cássio, corajoso ou honrado (a fuga de Flávio novamente o aproxima de lago). Sem grandeza trágica, esse Otelo de mentira também não se mata.

Retomando o comentário cômico do início do texto, mas agora em tom dramático, na cena final o ator Vasques também teve novamente a chance de 
repisar o assunto de sua capacidade para o drama e não só para a comédia, adicionando ainda uma outra camada de compreensão para o público da época. O pedido de Luís por aplausos reflete o pedido do próprio ator, fora de seu personagem, à coragem que tivera em encenar um drama.

A recepção da peça foi positiva. O crítico de $A$ Semana, talvez o escritor Valentim Magalhães, afirmou em 10 de abril de 1886:

"Há em toda a peça um largo sopro de verdade, e nalgumas cenas os autores revelam as suas excelentes qualidades de observadores; principalmente no primeiro ato, na cena entre o Caboclo e Luísa, e, no segundo, entre Luísa e Quitéria, que é realmente primorosa." 245

As expectativas de Vasques também foram contempladas, tendo os críticos elogiado seu trabalho, que chegou a ser descrito como "assombroso"246. Em outra apresentação, os aplausos são novamente documentados:

\begin{abstract}
"Esteve acima da expectativa e de qualquer elogio a festa de caridade realizada em benefício do Asilo Agrícola de Santa Izabel, na noite de 6 do corrente. Essa festa teve os auspícios e a proteção da princesa imperial, que com seu esposo e augustos pais assistiu a ela. O programa, em que bem se conhecia o sábio dedo do Mattos, qui s'y connait, foi magnificamente executado. O Caboclo agradou muito, sendo Vasques aplaudido com entusiasmo". 247
\end{abstract}

O comentário demonstra que o esforço de Vasques em provar seu valor dramático fora bem sucedido. Mesmo assim, a peça não foi além de uma dúzia de representações. Na época, o texto também não chegou a ser editado, tendo permanecido como manuscrito e sendo guardado pelo filho adotivo de Aluísio Azevedo, D. Pastor Azevedo Luques. Posteriormente, um bisneto de Emílio Rouède o doaria à Biblioteca Nacional do Rio de Janeiro em 1994, onde se encontra hoje disponível para consulta. A primeira edição da peça - que

\footnotetext{
${ }^{244}$ Id. Ibid., pp. 275-277.

${ }^{245}$ Apud FARIA, João Roberto. "Introdução", in Teatro de Aluísio Azevedo e Emílio Rouède. São Paulo, Martins Fontes, 2002, p. XXIII.

${ }^{246}$ Id. Ibid., p. XXV.

${ }^{247}$ Teatros. A Semana, ano II, no. 89, 11/09/1886, p. 298.
} 
utilizamos aqui - é de 2002, pela Editora Martins Fontes, na Coleção Dramaturgos do Brasil.

Nessa edição, a filiação de O Caboclo ao Naturalismo é analisada por João Roberto Faria:

"Os traços naturalistas acentuam-se, a começar pelo espaço social em que se passa a ação: uma fábrica de cigarros, situada num arrabalde do Rio de Janeiro. Não é muito comum que operários sejam personagens de peças teatrais no Brasil do século XIX. E não é um despropósito considerar que a sugestão possa ter vindo da leitura de romances naturalistas franceses (...) O que se deve enfatizar é que ao longo do drama alguns personagens referem-se ao temperamento violento dos caboclos brasileiros, como que preparando a cena final e o espírito do espectador para a tragédia inevitável. Afinal, fiéis aos postulados naturalistas, os autores fazem com que o protagonista aja de acordo com o seu temperamento e a sua herança genética, ao se ver traído pela esposa. Além disso, tratava-se de escrever o drama do adultério, não mais a comédia. $E$, de acordo com os padrões morais do século XIX, as aventuras extraconjugais das esposas eram mais condenáveis do que as dos maridos. (...)

Registre-se, pois, que, além de explorar com bastante competência o metateatro, $O$ Caboclo apresenta passagens felizes no sentido da reprodução da realidade (...)."248

Devemos ressaltar, por fim, a presença de Otelo, novamente como parte integrante e essencial do enredo de uma obra nacional do século XIX, agora em um gênero diferente - o drama naturalista. Um gênero que não vingou nos palcos nacionais, mas que produziu alguns frutos de qualidade, como atesta a obra que acabamos de apreciar.

${ }^{248}$ FARIA, João Roberto. Op. Cit., pp. XXI-XXIII. 


\subsection{5- OUTROS AUTORES}

A recorrência da personagem Otelo em obras da dramaturgia nacional, claro está, não deve se resumir às peças aqui elencadas até agora. Há notícias de outras composições, e mesmo de encenações, que remetem novamente ao mouro de Veneza.

Temos, por exemplo, notícia de uma peça escrita pelo ator português António José Areias (ou Arêas), residente no Rio de Janeiro e que trabalhou em várias companhias dramáticas do período, intitulada $O$ Caliche. A comédia em um ato, que hoje se encontra na seção de manuscritos da Biblioteca Nacional, era uma paródia de Otelo, mas foi considerada medíocre e teve negada licença para representação pelo Conservatório Dramático Brasileiro em 29/08/1858.

O Jornal do Comércio de 05/01/1871 anuncia, na página 4, a representação, pela companhia do artista Heller, de uma comédia chamada Othelo, tocador de Realejo. Era uma peça em um ato, talvez escrita pelo ator Costa Lima, que também a protagonizava. A edição da obra, de 1873, dá o autor como "anônimo". Na obra, o ator, no papel de Tortini, imitava Salvini e Rossi, os trágicos italianos que já haviam visitado Portugal, mas que ainda não haviam desembarcado no Brasil. Não há notícias de outras representações da peça, uma paródia que, por remeter tanto à peça quanto aos atores que a representavam, remete ao texto de Martins Pena, porém com qualidade muito inferior.

Além disso, devemos lembrar que as apropriações de Otelo não se limitam à dramaturgia, e nesse sentido o nome mais importante a ser lembrado é o de Machado de Assis.

Machado de Assis destaca-se, no Brasil, como profundo conhecedor de Shakespeare. Há inúmeras citações de diferentes obras do autor inglês em seus romances, contos, crônicas e poemas. O levantamento feito por JeanMichel Massa aponta na biblioteca de Machado as obras completas de 
Shakespeare em inglês e em francês, além de The Beauties of Shakespeare, de William Dodd ${ }^{24}$. Além disso, Machado estava familiarizado com a tradução de Otelo feita por Vigny, e também com a ópera verdiana sobre o mouro, a qual ele parecia apreciar muito ${ }^{250}$. Citações referentes ao mouro de Veneza pululam em sua obra - Caldwell ${ }^{251}$ conta 28 obras, entre contos, peças etc. nas quais Otelo é citado. Por outro lado, podemos ver em Dom Casmurro a peça shakespeariana como parte constituinte da trama. Devemos lembrar que não é a primeira incursão de Machado, em um romance, no ciúme: Ressurreição já trouxera o tema aqui retomado, e é comum analisar os elementos comuns às duas obras.

Em Dom Casmurro, o marido que se supõe traído, Bento Santiago, ao narrar a sua trajetória a fim de tentar "atar as duas pontas da vida", faz referência clara a Otelo em três capítulos: o LXII, "Uma ponta de lago", o LXXII, "Uma reforma dramática", e o CXXXV, chamado simplesmente "Otelo". No primeiro deles, Bento, no seminário, pergunta a José Dias como vai Capitu. A resposta do agregado ("Tem andado alegre, como sempre; é uma tontinha. Aquilo enquanto não pegar algum peralta da vizinhança, que case com ela....252) turva os sentidos do rapaz em um ataque de ciúme e de imaginação desenfreada. Em "Uma reforma dramática", o narrador propõe que as peças de teatro poderiam começar pelo fim, e usa Otelo para exemplificar:

\begin{abstract}
"Otelo mataria a si e a Desdêmona no primeiro ato, os três seguintes seriam dados à ação lenta e decrescente do ciúme, e o último ficaria só com as cenas iniciais da ameaça dos turcos, as explicações de Otelo e Desdêmona, e o bom conselho do fino lago: 'Mete dinheiro na bolsa'. Desta maneira, o espectador, por um lado, acharia no teatro a charada habitual que os periódicos Ihe dão, porque os últimos atos explicariam o desfecho do primeiro, espécie de conceito, e, por outro lado, ia para a cama com uma boa impressão de ternura e de amor:

"Ela amou o que me afligira,
\end{abstract}

\footnotetext{
${ }^{249}$ O levantamento completo sobre a biblioteca de Machado está em JOBIM, José Luís (org.) A Biblioteca de Machado de Assis. Rio de Janeiro, ABL / Topbook, 2001.

${ }^{250}$ Vide GOMES, Eugênio. O Enigma de Capitu. Rio de Janeiro, Livraria José Olympio Editora, 1967.

${ }^{251}$ CALDWELL, Helen. O Otelo Brasileiro de Machado de Assis. Cotia, Ateliê Editorial, 2002, p. 18.

${ }^{252}$ MACHADO DE ASSIS, J.M. Dom Casmurro. São Paulo, Editora Ática, 1996, p. 94.
} 
Eu amei a piedade dela". ${ }^{253}$

Finalmente, no capítulo CXXXV, "Otelo", no auge da crise de ciúme, Bento vai ao teatro ver Otelo, "que eu não vira nem lera nunca; sabia apenas o assunto, e estimei a coincidência". ${ }^{254}$ Narra seus sentimentos ao assistir à representação, e sai do teatro convencido de que sua esposa, culpada que era de adultério, deveria ter castigo muito pior do que o da inocente Desdêmona. Mesmo assim, após vagar pelas ruas, Bento continua, até o fim do capítulo, pensando em matar a si próprio, e não a Capitu.

Além das passagens mencionadas, há outros elementos que remetem a Otelo perpassando todo o texto. Apenas para citar um exemplo, há várias características que Escobar compartilha com Cássio: a bela figura, os dotes aritméticos, o fato de servir de "terceiro" (um termo, aliás, bastante significativo) para Bento e Capitu, levando a correspondência entre ambos no período de namoro. Outras peças de Shakespeare também são citadas textualmente, como As Alegres Comadres de Windsor (capítulo IX) e Macbeth (capítulo C).

Mas em que nível Otelo se embrenha na obra machadiana, ou é determinante para sua estrutura? Neste ponto, a crítica se divide. A maioria das linhas críticas não se ocupa da questão como um fator preponderante. Isso tanto é verdade se considerarmos a linha sociológica, representada por Astrojildo Pereira, Schwarz, Gledson e Faoro, quanto se tomarmos uma linha mais estilística, aos moldes de Augusto Meyer ou, contemporaneamente, de Alfredo Bosi. Contudo, poderíamos revisar alguns pontos de vista que privilegiaram essa questão, notadamente os de Helen Caldwell e de Eugênio Gomes. ${ }^{255}$

"E o veredicto?

\footnotetext{
${ }^{253}$ Id., ibid., p. 106.

${ }^{254}$ Id., ibid., p. 170.

${ }^{255}$ Deixamos de lado José Lemes Lopes, já que a sua linha psicológica se afasta do elemento literário para tentar conformar as personagens em categorias extra literárias. Lopes trata do assunto defendendo que a análise psicopatológica de Bento o aproxima de Otelo. Lopes chega a afirmar que o delírio de ciúme de Bento seria, inclusive, de origem homossexual, uma hipótese extremada que também já foi aventada em relação ao próprio mouro shakespeariano por críticos da mesma linha. Sobre as idéias de Lopes, vide CHAGAS, Wilson. A Fortuna Crítica de Machado de Assis. Porto Alegre, Editora Movimento, 1994, pp.43-45.
} 
Como Santiago observa no início do capítulo XCVIII, "Venceu a Razão", isto é, venceu o argumento legal. Praticamente três gerações - pelo menos de críticos - julgaram Capitu culpada.

Permitam-nos reabrir o caso.

O editor shakespeareano William J. Rolfe escreveu, a respeito de Desdêmona: "As evidências fornecidas pelo 'honesto lago' teriam convencido a todos de sua infidelidade em um tribunal". As evidências fornecidas pelo 'honesto Santiago' têm convencido muitos leitores, senão a maioria, acerca da infidelidade de Capitu; mas não serão essas evidências tão verdadeiras quanto a calúnia de lago?”256

Em O Otelo Brasileiro de Machado de Assis, publicado em 1960, Helen Caldwell defende a adesão absoluta da obra machadiana à peça de Shakespeare, adaptada e modificada pelo grande escritor brasileiro em um romance que é "a obra-prima de Machado de Assis e a estrela mais brilhante na galáxia da literatura brasileira". ${ }^{257}$

Pelo argumento de Caldwell, Bento é ao mesmo tempo Otelo e lago - pois, tendo José Dias cumprido tal papel a princípio (cap. LXII), logo é o próprio Santiago quem assume a tarefa caluniadora (convém lembrar que lago vem do nome Tiago, santo cujo epíteto é "o Mata-mouros"). Mas aqui, além de Bento envenenar e destruir o Otelo da trama - ele mesmo, antes de virar o Dom Casmurro -, acaba por fazê-lo também com o leitor, transformando-o assim em mais um Otelo que, como tal, aceita as acusações fictícias de lago, condenando Capitu-Desdêmona. ${ }^{258}$

Um dos problemas da argumentação de Caldwell deriva de que, ao identificar Bento com lago, ela conclui pela inocência absoluta de Capitu, recolhendo inúmeras "provas" ao longo do romance para provar sua hipótese. Porém, o fato de não podemos confiar no narrador, ou seja, de não podermos comprovar

\footnotetext{
${ }^{256}$ CALDWELL, Helen. O Otelo Brasileiro de Machado de Assis. Cotia, Ateliê Editorial, 2002, pp. 100101.

${ }^{257}$ Idem, ibidem, p. 215.

${ }^{258}$ Caldwell retomaria essa argumentação posteriormente, em Machado de Assis - the Brazilian Master and his Novels (1970), no qual defende a importância do título do romance para a compreensão do mesmo - "casmurro" significando não o que Bento quer que signifique, mas o que os dicionários da época apregoam: "obstinate, stubborn, wrong-headed"(p. 145).
} 
a culpa de Capitu, não implica na comprovação imediata da tese contrária. Em um tribunal que não fosse instituído por Bento, Capitu talvez fosse absolvida simplesmente por falta de provas - o que não necessariamente indica inocência. Contudo, no esquema de Caldwell, se acatarmos a identificação de Bento com Otelo/lago, forçoso é tomar Capitu como Desdêmona, com toda a sua pureza.

Caldwell vê ainda ecos de outras obras shakespearianas em Dom Casmurro. Além de Macbeth, ela se remete a Hamlet, a Romeu e Julieta, e a Conto de Inverno (além de identificar o amor de Capitu com o de Julieta, "enorme como o mar", ela vê semelhanças entre a situação da personagem machadiana e a da heroína Hermione, injustamente acusada de adultério).

Estudioso contumaz de Machado de Assis, Eugênio Gomes não compactua com as idéias de Caldwell. Na verdade, logo após a publicação de The Brazilian Othello of Machado de Assis, ele viria a resenhá-lo, e a atacar suas conclusões em três artigos ${ }^{259}$. Posteriormente, escreveria O Enigma de Capitu, livro no qual expõe suas próprias teorias a respeito do romance machadiano, e que responde não apenas à argumentação de Caldwell ${ }^{260}$, como também à de Aloísio de Carvalho Filho ${ }^{261}$.

Nessa obra, tentando deslindar o enigma da culpabilidade ou inocência de Capitu, as conclusões a que Eugênio Gomes chega são as seguintes: que

\footnotetext{
${ }^{259}$ Publicados primeiramente no Correio da Manhã, do Rio de Janeiro, intitulados "A Simbologia de Dom Casmurro"(25/05/1960), "Que há num nome?"(09/07/1960) e "Absolvição de Capitu”(23/07/1960). ${ }^{260}$ GOMES, E. O Enigma de Capitu Rio de Janeiro, Livraria José Olympio Ed., 1967. Gomes se encarrega, aí, de refutar inclusive passagens menores da argumentação de Caldwell, como aquela, na p. 166 de seu livro, de que o título do último capítulo de Dom Casmurro, "E bem, e o resto?", seria uma referência às palavras finais de Hamlet na tragédia homônima:

“(...) e o resto? Pode parecer que advém do Hamlet, mas não; representa um dos muitos chavões estilísticos do escritor, através de várias passagens de sua obra, sem comprometer a naturalidade da linguagem oral: '... conto-lhe o que se passou outro dia, o penteado e o resto..." (Cap. XL); 'o resto fezme ficar mais algum tempo no corredor, pensando.' (Cap. XLI); 'mas há leitores tão obtusos, que nada entendem, se se lhes não relata tudo e o resto. Vamos ao resto.' (Cap. CIX); 'O resto come-me ainda muitos capítulos.' (Cap. CX); 'O resto em Dante.' (Cap. CXXIX); '... depois do que ouvi, [diz Capitu a Bentinho] posso ouvir o resto, não pode ser muito.'(Cap. CXXXVIII). Pelo visto, foi essa última réplica indignada de Capitu que deu origem à reiteração do termo: resto, no derradeiro capítulo". (Op. Cit.,p.7)

${ }^{261}$ Carvalho Filho publicara em 1963 O Processo Penal de Capitu, obra na qual a personagem era incriminada judicialmente com base nas provas apresentadas por Bentinho (vide ALVES, Ívia. Visões de Espelhos - o Percurso da Crítica de Eugênio Gomes. São Paulo, tese de doutoramento apresentada à FFLCH/USP, 1995, 2v., p. 124 e seguintes).
} 
nada se pode afirmar, pois a convicção e a imaginação desenfreada do narrador o (e nos) impedem de ver com clareza os fatos; que o próprio narrador contempla o fato de que a semelhança física entre duas pessoas pode ser uma coincidência; que uma das questões do livro, paralela à de se a Capitu da praia da Glória já estava dentro da de Matacavalos, é a de se Bentinho já era casmurro "desde os primeiros tempos ou ele só veio a sê-lo na derradeira parte de sua existência" "262; que "no hospício de Simão Bacamarte, Bentinho teria lugar certo entre os monomaníacos, principalmente após sua extravagante idéia de destruir a casa da Rua de Mata-Cavalos, porque as coisas de lá se riam dele"263. Gomes ainda faz algumas considerações sobre as semelhanças entre Machado e Bentinho, o que condiz com sua tendência a uma análise mais psicologizante, e analisa detalhadamente tudo o que há de Otelo em Dom Casmurro. ${ }^{264}$

Outro elemento importante levantado por Gomes é a semelhança entre Dom Casmurro e uma obra de Émile Zola, Madeleine Férat, romance no qual a filha da protagonista é muito parecida com o antigo amante da mãe, fato que o marido de Madeleine percebe quando a criança tem quatro anos e tem por diversão imitar os outros. Além disso, Jacques, o antigo amante, fora amigo de infância do marido "traído", e supunha-se que morrera em um naufrágio. Zola dá à semelhança entre Jacques e Lúcia, a menina, explicações fisiológicas, à luz da ciência experimental. Gomes aponta a popularidade do Naturalismo de Zola na época da composição de Dom Casmurro, e pontua a admiração do próprio Machado pelo autor francês. Gomes coloca Otelo como apenas um dos elementos dos quais Machado se vale para compor o livro, ressaltando as semelhanças maiores do mesmo com esta outra obra, especialmente no tocante ao enredo e às reações do marido supostamente traído. Ou seja, Gomes não nega que Otelo esteja presente, mas não lhe dá a importância constitutiva que a crítica norte-americana pretende.

Ele também corrige Caldwell na afirmação desta de que, aparentemente, nada na obra machadiana remeta à ópera de Verdi:

\footnotetext{
${ }^{262}$ Id., ibid., p. 161.

${ }^{263}$ Id., ibid., p. 161.
} 
"A audição direta dessa ópera [Macbeth] ou simplesmente a tradição popular de alguns de seus trechos, entre os quais predominaria necessariamente aquela frase profética das feiticeiras, dispensava o conhecimento do original inglês. Isto mesmo poderia ter ocorrido relativamente à tragédia de Otelo, a cujo desempenho Bentinho foi assistir quando atravessava o momento mais crítico de seus ciúmes, e começa por dizer que 'não vira nem lera nunca' esse drama, de que sabia apenas o assunto. Está subentendido que fora ver uma representação dramática, mas em capítulo anterior ( $L X X X I)$, ao citar uma passagem da peça: 'Ela amou o que me afligira / Eu amei a piedade dela', o pseudo-autor teria em mente a ópera. O segmento métrico desses versos não corresponde às traduções conhecidas da peça, aproximando-se antes da letra da ópera de Verdi: E tu m'amavi per la mia sventure / Ed io t'amavo per la tua pietà. Acresce que, em nossa língua, não havia ainda nenhuma tradução metrificada do Otelo e, a menos que fosse de alguma versão adotada pelos trágicos italianos, Rossi e outros, que estiveram no Brasil, aquela citação procede do teatro lírico"265.

Ainda que a citação venha realmente da ópera, Bentinho só deve tê-la visto quando já era sozinho e casmurro. Devemos lembrar que a estréia do Otello verdiano no Rio de Janeiro se deu em 1889. Assim, mesmo que o narrador se remeta a seu libreto, não deve ter sido este o espetáculo a que assiste no capítulo "Otelo", visto que a morte de Escobar fora em 1871, e Capitu chama a atenção de Bentinho para a semelhança entre os olhos do filho, Ezequiel, e os do morto já em 1872 (Cap. CXXXI).

De volta à argumentação de Gomes, este prossegue com hipóteses menos prováveis de aproximação com o Otelo verdiano, como a de que a cena do beijo evoca o final do $1^{\circ}$ ato da ópera, e, no clímax do romance, mostra a semelhança com os termos do libreto de Boito:

"Quando Capitu assume finalmente a seus olhos a figura de ré, o advogado Bentinho maneja ainda a terminologia profissional para efeito estético. (...) Bentinho assinala: 'Podia estar um tanto confusa, o porte não

${ }^{264}$ Id., ibid., pp. 118-123. 
era de acusada. Pedi-Ihe ainda uma vez que não teimasse.' A tal pedido, Capitu reage com redobrado vigor de indignação: 'Não, Bentinho, ou conte o resto, para que eu me defenda, se você acha que tenho defesa, ou peçoIhe desde já a nossa separação: não posso mais!' Em circunstâncias semelhantes, na ópera de Verdi, tão conhecida do romancista brasileiro, Desdêmona protesta vivamente: 'Io rea non sono!"’266

Mesmo com tantos exemplos, Gomes termina por também relativizar a importância na ópera verdiana frente a outras:

\begin{abstract}
"Não há dúvida que o narrador deixa transparecer os efeitos da ópera lírica sobre a concepção do romance (...) [que] influíram no seu espírito: o Fausto e, por extensão, com maior ou menor força, Mefistófeles e Otelo, respectivamente de Gounod, Boito e Verdi. Quando se tenta apreender a temática da narrativa por esse prisma, vê-se que a do ciúme se desdobra quase insensivelmente na do rejuvenescimento. E, como deste são as primeiras manifestações, Fausto precede e, depois de certa altura, rende Otelo. Quase desaparecem as personagens de sua tragédia familiar, porque, à tortura do ciúme, segue-se finalmente a da velhice". 267
\end{abstract}

Assim, Gomes corrige parte das informações de Caldwell, e ao mesmo tempo propõe uma outra linha de investigação. Deixa clara a diferença entre Bento e Otelo, apesar do fascínio que o mouro exerce sobre o Casmurro, diferença que já apontara em outra obra sua, Shakespeare no Brasil:

"Quando se comparam os ciúmes de Brás Cubas ou Rubião com os de Bentinho, não é difícil verificar por que razão os ecos da tragédia de Otelo ressoam de maneira mais patética em Dom Casmurro (...) Apesar dessas reflexões [de Bento após assistir ao Otelo], Bentinho não se conduziu como o general mouro, exterminando de maneira ainda mais cruel a sua

\footnotetext{
${ }^{265}$ Id., ibid., pp. 79-80.

${ }^{266}$ Id., ibid., pp. 149-150.

${ }^{267}$ Id., ibid., pp. 80-81.
} 
Desdêmona. Não se matou tampouco. Era um personagem de Machado..."268

Mesmo se considerarmos as conclusões de Caldwell exageradas, há em seu estudo um mérito que foi tocar em um ponto nevrálgico sobre a composição do romance, e que influenciaria toda a crítica posterior: o ponto de vista. $\mathrm{O}$ fato hoje quase reconhecido como óbvio de que não podemos decidir sobre a culpabilidade de Capitu por ser Bentinho o narrador do romance foi um elemento que por décadas não foi sequer mencionado pela crítica, que acatava os dados do narrador. O próprio Roberto Schwarz afirma:

\begin{abstract}
"Acaso ou não, só sessenta anos depois de publicado e muito reeditado o romance, uma professora norte-americana (por ser mulher? por ser estrangeira? por ser talvez protestante?) começou a encarar a figura de Bento Santiago - o Casmurro - com o necessário pé atrás. (...) Helen Caldwell, a quem as acusações de Bentinho a Capitu pareceram infundadas e ditadas pelo ciúme, publicou o seu The Brazilian Othello of Machado de Assis em 1960. Punha a descoberto o artifício construtivo da obra, a idéia insidiosa de emprestar a Otelo o papel e a credibilidade do narrador, deixando-o contar a história do justo castigo de Desdêmona. No básico, a charada literária que Machado armara estava decifrada”. ${ }^{269}$
\end{abstract}

Quer aceitemos ou não as semelhanças de Bentinho com Otelo, de José Dias ou do próprio Bento com lago, e de Escobar com Cássio, resta-nos o lugar de Capitu. A figura de Desdêmona, em qualquer das versões correntes no Brasil no século XIX - a de Shakespeare, a de Ducis, as óperas de Rossini e de Verdi - é a pura imagem da inocência. Nenhuma dúvida paira sobre ela. Como indica um estudo das heroínas de Shakespeare escrito no período:

"Através de todas as falas de Desdêmona, não há uma só observação de caráter geral. As palavras são para ela portadoras de sentimento, e nunca

\footnotetext{
${ }^{268}$ GOMES, Eugênio. Shakespeare no Brasil. Rio de Janeiro, MEC/Serviço de Documentação, 1961, pp. 177-178. A mesma observação, em outras palavras, encontra-se em Machado de Assis - Influências Inglesas. Rio de Janeiro, Pallas; Brasília, INL, 1976, p. 28.

${ }^{269}$ SCHWARZ, Roberto. Duas Meninas. São Paulo, Companhia das Letras, 1997, pp. 9-11. São importantes suas considerações acerca das leituras sucessivas de Dom Casmurro, desnudando as intenções do narrador.
} 
de reflexão; tanto que me é impossível encontrar em toda a peça uma frase de aplicação geral. A mesma afirmação se aplica a Miranda: e a nenhuma outra personagem feminina de importância ou interesse; nem mesmo Ofélia". ${ }^{270}$

Isso não coaduna com Capitu. Mesmo se não formos levados pelo narrador a condená-la já de saída, uma dúvida nos assalta. Se não podemos ter certeza da culpa, também não podemos afirmar o contrário, como tentou fazer Caldwell. Essa dúvida faz lembrar uma outra personagem da literatura brasileira do século XIX, esta sem dúvida inspirada em Desdêmona e conhecida de Machado de Assis: Leonor de Mendonça.

Não podemos chegar ao ponto de afirmar que Machado tenha se inspirado em Leonor ao compor Capitu, mas um epíteto parecido poderia ser aplicado a ela; de mais a mais, além de Machado certamente conhecer a obra, não seria a primeira vez que ele se referiria a uma obra brasileira anterior, como lembra Schwarz ao evocar a semelhança de um episódio de Marcela, em Memórias Póstumas de Brás Cubas, com Lucíola, de José de Alencar. ${ }^{271}$

O fato é que a dúvida nos assalta em Capitu. Quem é Capitu? É pura e quase santa, como Desdêmona? Como Leonor, é uma "duquesa agradecida e imprudente ${ }^{272,}$, ou um pouco mais do que isso? Ou é mesmo uma cigana oblíqua e dissimulada, como quer Bento?

Seja como um elemento estruturante ou simplesmente uma citação recorrente, o fato é que Otelo se embrenha em Dom Casmurro, e não por acaso. Poderíamos mesmo dizer que a presença de Otelo é importante, até, por problematizar a questão do acesso à inocência, do saber a verdade, para as personagens e para o público. No gênero dramático, a facilidade é maior: não há o filtro do narrador. Já no romance, temos as escolhas do narrador, o juízo de quem diz sobre o que é feito e dito (especialmente em uma obra com

\footnotetext{
${ }^{270}$ JAMESON, Anna. Shakespeare's Heroines. New York, Gramercy, 2003. Este livro foi originalmente publicado em 1832, e é considerado o primeiro estudo das personagens femininas em Shakespeare.

${ }^{271}$ SCHWARZ, Roberto. Um Mestre na Periferia do Capitalismo: Machado de Assis. $4^{\mathrm{a}}$ ed. São Paulo, Duas Cidades; Editora 34, 2000, p. 77 e seguintes.
} 
narrador em primeira pessoa). Em Otelo, temos acesso à inocência de Desdêmona por suas palavras e atos, e por acompanharmos desde o início de posição privilegiada o desenrolar do plano de lago. Em Leonor de Mendonça, vemos os atos da protagonista e temos acesso, até mesmo, ao seu interior, na cena da confissão, compreendendo sua oscilação. Mas tudo o que vem de Capitu encontra-se maculado pela impressão de Bento, seja sua aparência, sejam seus atos, sejam suas palavras. O "enigma de Capitu" continua forte. E Otelo, se não resolve o enigma, ainda assim está no romance, ao mesmo tempo reforçando e contradizendo, revelando e encobrindo. Se Bentinho "não lera nem vira nunca" a obra shakespeariana, ou depois não percebeu direito a importância desta para sua própria vida, Machado de Assis com certeza o fez.

${ }^{272}$ DIAS, Gonçalves. Teatro Completo. Rio de Janeiro, SNT, 1979, p. 63. 


\section{2 - OTELO COMO EXPRESSÃO CORRENTE}

É preciso ressaltar que, além das obras já elencadas, que se apropriam mais diretamente do enredo e/ou das personagens de Otelo, em maior ou menor grau - seja a partir de uma das versões escritas, seja de uma encenação, ou mesmo de ambas, - vários autores brasileiros citam a personagem Otelo en passant, para exemplificar ou para ilustrar uma situação. Com isso, podemos perceber que a relação entre Otelo e o homem ciumento, ou entre Desdêmona e a inocência, trazem imagens imediatas e reconhecíveis, presumidamente, para a platéia ou os leitores de tais autores; daí se depreende que o conhecimento das personagens e de seus traços era "moeda corrente" no Brasil da época da composição das obras em questão, ou pelo menos seus autores assim o criam ou desejavam.

Logicamente, não são apenas peças de teatro que se valem de Otelo. Contudo, tentaremos aqui nos ater a textos dramatúrgicos ou sobre teatro. Não pretendemos fazer um levantamento exaustivo de citações, portanto focaremos apenas em alguns autores, de diferentes períodos do século e diferentes estilos: Martins Pena, Álvares de Azevedo, França Júnior e Machado de Assis.

O primeiro exemplo é Martins Pena, que, antes de Os Ciúmes de um Pedestre já fizera menção ao Otelo de Ducis em sua comédia O Juiz de Paz da Roça. Escrita provavelmente em 1833, e revista em 1837, ano da estréia da encenação de João Caetano, é uma das peças mais conhecidas do autor. Nela, a personagem Faustino, empregado público, reclama que um guarda o espera à porta de sua repartição para prendê-lo por esquivar-se do trabalho, e diz-se perseguido pelo capitão da Guarda Nacional. Irritado, exclama:

"FAUSTINO - (...) Felizes dos turcos, dos chinas e dos negros de Guiné, porque não são guardas nacionais! Oh!

Por que lá nos desertos africanos

Faustino não nasceu desconhecido!"273

\footnotetext{
${ }^{273}$ MARTINS PENA, Luís Carlos. As Melhores Comédias de Martins Pena. Porto Alegre, Editora Mercado Aberto, 1987, p. 158.
} 
A citação refere-se diretamente ao texto duciano, no trecho em que Pézaro vem a Othelo afirmar ter provas da infidelidade de Hedelmonda:

"OTHELO - Por que nos seus desertos africanos

Othelo não morreu desconhecido?"274

Após Martins Pena, um outro bom exemplo de autor brasileiro que lida com Otelo, ainda que com parâmetros completamente distintos, é o escritor romântico Álvares de Azevedo.

Álvares de Azevedo não é um romântico de primeira geração, esta mais ligada a idéias de Victor Hugo. Sua ligação com o Romantismo é pela vertente byroniana, menos ligada ao nacionalismo e mais à questão da individualidade $\mathrm{e}$ dos sentimentos, especialmente em relação ao amor e à morte. Em termos teatrais, o escritor afigura-se como um dos primeiros grandes leitores da obra shakespeariana no Brasil. Referências às obras do dramaturgo inglês pululam em seus escritos, especialmente Hamlet e Romeu e Julieta. Contudo, também podemos encontrar reflexões que se remetem a Otelo em vários de seus textos.

Suas idéias em relação ao teatro são discutidas em pelo menos dois textos não-ficcionais importantes: Carta sobre a Atualidade do Teatro entre nós e Puff: Prefácio a Macário, ambos escritos provavelmente em 1851.

No primeiro texto, Álvares de Azevedo critica o estado de miséria da cena nacional e, entre outros, defende a encenação das peças de Shakespeare:

"O Sardanapalo de Byron, traduzido por uma pena talentosa, foi julgado impossível de levar-se à cena. No caso do Sardanapalo estão os dramas de Shakespeare que, modificados por uma inteligência facunda deveriam produzir muito efeito. Se o povo sabe o que é o Hamlet, Otelo, deve-o ao

\footnotetext{
${ }^{274}$ MAGAlhãES, D.J.G. de. Obras de D.J.G. de Magalhães - Tomo III - Tragédias. Rio de Janeiro,
} Livraria de B.L. Garnier, 1865, p. 333. 
reflexo gelado de Ducis. Contudo, seria fácil apresentar-se no Teatro de S. Pedro alguma coisa de melhor do que isso. Com o simples trabalho da tradução se poderiam popularizar os trabalhos de Émile Deschamps, Auguste Barbier, Léon de Wailly e Alfredo de Vigny que traduziram Romeu e Julieta, Macbeth, Júlio César, Hamlet e Otelo." 275

Note-se o olhar crítico sobre Ducis e a predileção pelo texto original, ainda que através de traduções francesas. Ao longo do texto, podemos perceber que, além de citar Otelo, Hamlet e Macbeth, as tragédias levadas por João Caetano, Álvares de Azevedo também demonstra intimidade com as comédias shakespearianas.

Em Puff, o autor pretende expor algumas de suas idéias sobre o drama, e logo de saída já inclui Shakespeare em seu ideal de teatro:

\begin{abstract}
"O meu protótipo seria alguma coisa entre o teatro inglês, o teatro espanhol e o teatro grego: a força das paixões ardentes de Shakespeare, de Marlowe e Otway, a imaginação de Calderón de la Barca e Lope de Vega, e a simplicidade de Ésquilo e Eurípides; alguma coisa como Goethe sonhou, e cujos elementos eu iria estudar numa parte dos dramas dele, em Goetz de Berlichingen, Clavijo, Egmont, no episódio da Margarida de Fausto e a outra na simplicidade ática de sua Ifigênia (...)”276
\end{abstract}

Um pouco mais à frente, refere-se especificamente a Otelo para discorrer sobre a opinião que tem de Shakespeare:

"É um tipo talvez novo, que não se parece com o misticismo do teatro de Werner, (...). Não se pareceria com o de Ducis, nem com aquela tradução bastarda, verdadeira castração de Otelo de Shakespeare feita pelo poeta sublime de Chatterton, o conde Vigny. Quando não se tem alma adejante para emparelhar com o gênio vagabundo do autor de Hamlet, haja ao menos modéstia bastante para não querer emendá-lo. Por isso o Otelo de Vigny é morto. Era uma obra de talento, mas devia ser um rasgo de gênio.

\footnotetext{
275 AZEVEDO, Álvares de. "Carta sobre a Atualidade do Teatro entre Nós”, in FARIA, João Roberto. Idéias Teatrais: o Século XIX no Brasil. São Paulo, Perspectiva/FAPESP, 2001, p. 357.

${ }^{276}$ AZEVEDO, Álvares de. Macário. Porto Alegre, L\&PM, 2001, p. 11.
} 
"Emendá-lo! Pobres pigmeus que querem limar as monstruosidades do Colosso! Raça de Liliput que quereria aperfeiçoar os membros do gigante disforme para eles de Gulliver!"277

Ao longo do texto, torna-se claro que sua idéia de drama assemelha-se ao protótipo shakespeariano, sendo Otelo a peça mais citada:

"Se eu escrevesse, se minha pena se desvairasse na paixão, eu a deixaria correr assim: lago enganaria o Mouro, trairia Cássio, perderia Desdêmona e desfrutaria a bolsa de Rodrigo. Cássio seria apunhalado na cena. Otelo sufocaria sua Veneziana com o travesseiro, escondê-la-ía com o cortinado quando entrasse Emília; chamaria sua esposa - a whore - e gabar-se-ia de seu feito. O honest, most honest lago viria ver a sua vítima, Emília soluçando a mostraria ao demônio; o Africano delirante, doido de amor, doido de a ter morto, morreria beijando os lábios pálidos da Veneziana (...).

\footnotetext{
"Se eu imaginasse o Otelo, seria com todo seu esgar, seu desvario selvagem, com aquela forma irregular que revela a paixão do sangue. É que as nódoas de sangue quando caem no chão não têm forma geométrica." 278
}

Na peça Macário, contudo, não há referências a Otelo especificamente, mas sim a Shakespeare e outras de suas obras e personagens (Caliban, Hamlet, Romeu, Falstaff). Se concordarmos com Antonio Candido, porém, em seu estudo "A Educação pela Noite", que propõe uma unidade de Macário com Noite na Taverna ${ }^{279}$, encontraremos ainda algumas referências. Nesta última obra, no episódio III (“Bertram”), cita-se Otelo duas vezes:

"Foi ela, vós o sabeis, quem fez-me num dia ter três duelos com meus três melhores amigos, abrir três túmulos àqueles que mais me amavam na vida - e depois, depois sentir-me só e abandonado no mundo, como a

\footnotetext{
${ }^{277}$ Id. Ibid., pp. 11-12.

${ }^{278}$ Id. Ibid., pp. 14-15.
} 
infanticida que matou o seu filho, ou aquele Mouro infeliz junto "a sua Desdêmona pálida!"280

E, pouco adiante:

"Mas um dia o marido soube tudo: quis representar de Otelo com ela. Doido..."281

Há outras obras do autor que também fazem alusões a Shakespeare e Otelo, como discursos, cartas e escritos esparsos, além de poemas como A Cantiga do Sertanejo, É ela! É ela! É ela! É ela! e A Harmonia, todos da Lira dos Vinte Anos.

Mais à frente, encontramos novas referências nas obras do comediógrafo França Júnior (1840-1890). Especialista em comédias leves e satíricas, em suas obras Otelo é citado mais de uma vez.

Em sua primeira peça, Meia Hora de Cinismo, escrita quando ainda era estudante da Faculdade de Direito de São Paulo, em 1861, as personagens Nogueira e Frederico, falando sobre a paixão que um amigo, Trindade, nutre por uma jovem, dizem:

"NOGUEIRA - (...) é pela filha do Juca do Braz. Passa por lá todas as tardes, e é raro o dia que não venha para casa meio triste e meio alegre.

FREDERICO - Explica-te.

NOGUEIRA - Alegre, porque vê a bela, e triste, porque lhe dão vaias. A vaia parte da casa do Martins, e amanhã convido-te para apreciarmos de lá o pagode. É uma paixão de Otelo!

FREDERICO - Qual, isto é um gracejo teu, porque realmente a Desdemonda é uma lambisgóia.

NOGUEIRA - É uma paixão diabólica que o levou à loucura de empenhar um fraque!"282

279 Vide o estudo introdutório da edição citada: CANDIDO, Antonio. "A Educação pela Noite", in AZEVEDO, Álvares de. Teatro de Álvares de Azevedo. São Paulo, Martins Fontes, 2002, pp. IX-XXX ${ }^{280}$ AZEVEDO, Álvares de. Op. Cit., p. 112.

${ }^{281}$ Id. Ibid., p. 114. 
A forma Desdemonda não deixa de ser interessante, estando na metade do caminho entre Hedelmonda e Desdêmona, entre Ducis e Shakespeare. Reflexo das versões contrastantes já presentes em solo brasileiro em 1861? Erro do autor? De qualquer modo, aqui Otelo serve como modelo exemplar de paixão desenfreada.

Em Amor com Amor se Paga, de 1871, (que também cita Romeu e Julieta), Emília, que veio encontrar-se com Miguel, ouve a voz de seu marido - que, sem ela saber, tenta namorar a esposa de Miguel - e desmaia. Ao acordar, pergunta:

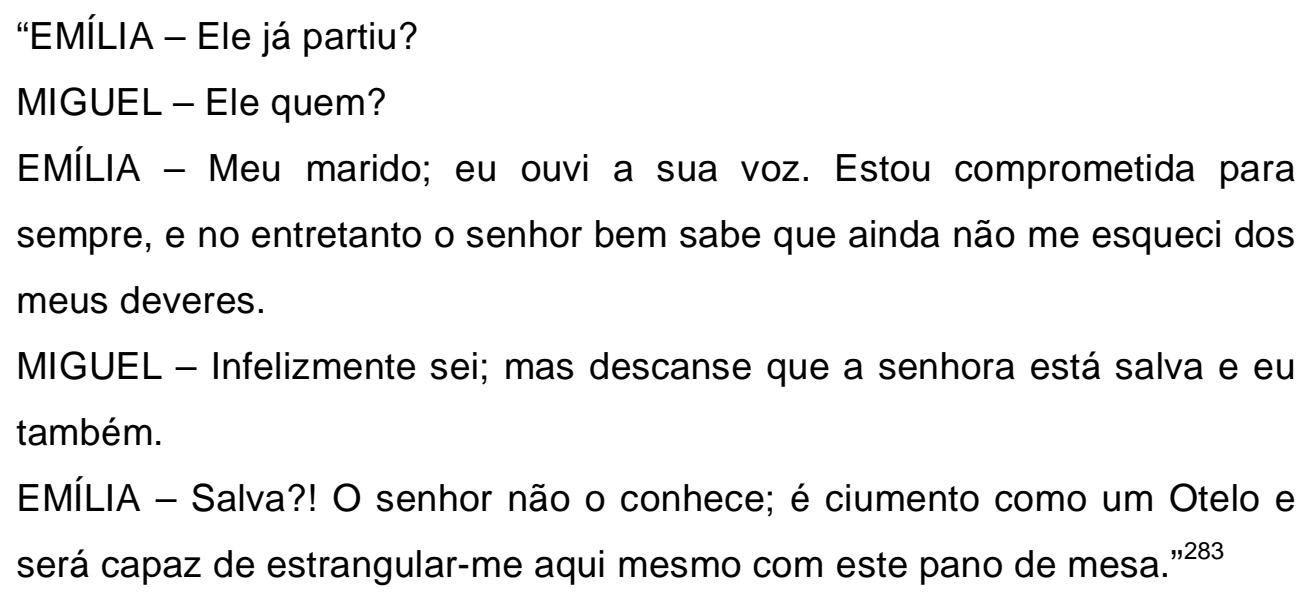

Aqui, a referência ao estrangulamento permite identificarmos a fonte como a versão shakespeariana. Novamente, Otelo é um modelo exemplar, desta vez do marido ciumento.

Maldita Parentela, também de 1871, traz a personagem Hermenegilda, que adora fazer citações mas termina pronunciando apenas asneiras, confundindo autores e dizendo bobagens. Mal chega ao baile na casa de Damião (que morre de vergonha dos parentes da mulher), diz:

\footnotetext{
${ }^{282}$ FRANÇA JÚNIOR, Joaquim José de. Teatro de França Júnior I. Rio de Janeiro, Museu Histórico Nacional, 1977, p. 62.

${ }^{283}$ Id. Ibid., pp. 106-107.
} 
"HERMENEGILDA (Cumprimentando a todos.) - Pensei que não nos apropinquássemos mais às avenidas deste palácio, todo por dentro e por fora iluminado, como diz Alexandre Heculano [sic] no Otelo.

DAMIÃO (À parte.) - Faltava mais este casal para coroar a obra." 284

Finalmente, podemos encontrar Otelo na obra de Machado de Assis. Como já dissemos, Machado é um grande leitor de Shakespeare, e referências ao mouro de Veneza são encontradas em romances (além de Dom Casmurro, temos Helena - cap. XXV, e Quincas Borba - cap. CXLIII), crônicas, e poesias (como Tristeza). Na dramaturgia de Machado, Otelo não comparece amarrando uma trama completa, mas há referência ao texto shakespeariano em $O$ Protocolo.

Nesta peça, de 1862, Pinheiro, o marido, suspeita das intenções de Venâncio Alves em relação à sua esposa, e afirma pretender "arrancar-Ihe as orelhas", ao que a esposa retruca:

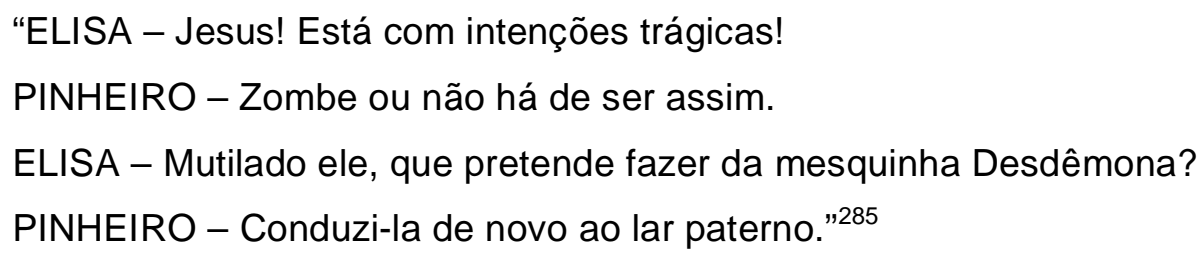

Como podemos perceber, as personagens de Otelo são citadas em diferentes textos, sejam eles dramáticos ou não, para tratar de certas características como o amor e o ciúme. Não são os únicos exemplos, certamente; poderíamos citar ainda vários outros escritores que se valem de Otelo em suas composições, como os poetas Olavo Bilac e Cruz e Sousa. De qualquer modo, pelas citações acima podemos perceber que o conhecimento compartilhado do que significa "Otelo" ou "Desdêmona" é claro para os autores, que escolhem esses modelos para exemplificar as tais características mencionadas a seus leitores e platéias.

\footnotetext{
${ }^{284}$ Id. Ibid., pp. 164-165.

${ }^{285}$ MACHADO DE ASSIS, J.M. Teatro Completo. Rio de Janeiro, MEC / SNT, 1982, p. 126.
} 


\section{CONCLUSÃO}

"Shakespeare is an inexhaustible subject, hence narratives of his reception cannot permit themselves the ultimate luxury of total exhaustiveness."

Roger Paulin

Como podemos nos recordar, a proposta desta tese era responder à seguinte pergunta: quais os Otelos que aportaram no Rio de Janeiro do século XIX, e quais suas contribuições para a criação do repertório dramatúrgico nacional?

Havia várias questões diretrizes elencadas em relação a este objetivo maior, que se referiam a hipóteses sobre o tema, a saber: o Otelo de Ducis dominaria a cena nacional e inspiraria autores em um patamar acima de Shakespeare; a encenação de João Caetano é central para a recepção da personagem no Brasil; outras versões, inclusive a de Shakespeare, também circulam e às vezes se misturam; é só com o passar do tempo que o texto shakespeariano se impõe como fonte; a importância da personagem é grande o suficiente para receber atenção concentrada em certas obras de autores nacionais que tiveram contato com textos e/ou encenações de Otelo, e ainda para ser citada de passagem em outras obras, o que pressupõe conhecimento compartilhado entre autores e leitores/público.

Neste trabalho, pudemos traçar o percurso da personagem Otelo nos palcos cariocas do século XIX, bem como analisar obras dramáticas nacionais que se valeram destas encenações e das diferentes versões textuais do enredo. Com isso, pudemos confirmar a importância tanto da versão de Ducis para a obra quanto a de João Caetano, em um certo período do teatro brasileiro. As evidências da ampla repercussão e discussão da personagem e da obra podem levar-nos a considerar Otelo, inclusive, como uma personagem fundamental do repertório brasileiro em seu momento de formação. 
Vários fatores concorrem para que assim o seja, entre eles até o fato do adultério feminino ser um dos temas estruturantes da literatura do século XIX. Mas as razões principais deste fenômeno parecem derivar da atenção dada a encenações de versões da peça em dois momentos distintos do século: entre 1837 e 1856, com João Caetano, e a partir de 1871, com as companhias estrangeiras que incluíram o Rio de Janeiro em suas rotas de apresentação.

Nesse sentido, cabe destacar a importância seminal de João Caetano como parâmetro e modelo de Otelo para o nosso teatro, o que é corroborado não apenas pelas peças que remetem à sua encenação da tragédia de Ducis traduzida por Gonçalves de Magalhães, como também à retomada de seu nome, anos depois, ao desembarcarem no Rio de Janeiro os Otelos italianos e portugueses. A discussão sobre a primazia de João Caetano sobre os estrangeiros, ou seu mérito comum, foi assunto de vários escritos nos periódicos da época, por autores que muitas vezes nem tinham visto o ator brasileiro em cena. A comparação mais comum, com os arroubos e as cenas intempestivas de Ernesto Rossi, é feita como se os atos deste justificassem as escolhas artísticas daquele, realizadas décadas antes, comprovando seu gênio e seu talento inato, já que não tivera ele mesmo modelos aos quais recorrer.

Se as conclusões desses autores são questionáveis, o certo é que a composição de João Caetano do papel do Mouro de Veneza deixou impressão perene em sua platéia, que se voltaria para ele como o primeiro grande astro nacional, às vezes até com um certo saudosismo, e que depois incitaria estudos como os de Pires de Almeida, esforçando-se para ligar seu nome ao de Shakespeare - em uma época em que a versão shakespeariana já triunfara irremediavelmente contra o neoclassicismo duciano. Assim, ter o nome do primeiro ator do país ligado ao do grande dramaturgo inglês concorreria ainda mais para a sua glória.

De qualquer modo, é exemplar a historieta narrada por Luís Antônio Giron, sobre uma experiência de Gonçalves Dias em 1849, mascarado, em uma festa à fantasia: 
"Fantasiado como Otelo, o crítico vai ao baile do teatro. Encontra a casa cheia, brilhante de máscaras e de luzes. Uma marquesa espevitada se aproxima para iniciar o jogo da adivinhação, situação nova para quem estava acostumado à desmascarada crueza em praça pública do entrudo. 'Otelo, que fazeis tão pensativo?', diz a moça. Ele oferece o braço, ao que ela responde: 'Sabes que tenho medo de morrer?' Otelo: 'Ah! Juro-vos que meus golpes não são mortais para vós!' Nota que a moça o confundiu com o famoso ator João Caetano. 'Com efeito, pela estatura e mesmo pela voz, debaixo da máscara de valente mouro de Veneza, poderão confundir-nos, e a prova é que muitos nessa noite se enganaram, e eu confesso que senti um vivo prazer em passar pelo primeiro artista dramático de meu país'.

"O cônego, personagem descrito na batalha do entrudo, aparece no salão, lamentando-se de que não haverá ceia ao final do baile. E Otelo salta sobre o reverendíssimo e parodia a fala da peça de Shakespeare: 'A prova, disse, a prova, dai-m'a! A orquestra, dando o sinal para a continuação das danças, livrou o cônego deste perigo'. Era uma 'peta' do religioso, pois houve boa ceia ao final." 286

Ser confundido com João Caetano, em seu papel mais conhecido... não admira o prazer que Gonçalves Dias sentiu na situação, dada a importância do ator carioca, que como vimos perduraria ainda por muito tempo.

Outro ponto capital é o reconhecimento da importância da vinda das companhias estrangeiras ao Rio de Janeiro. Com elas, vemos a criação de novos parâmetros de texto e de interpretação para o Otelo no Brasil. Desembarca finalmente nos palcos a peça shakespeariana, antes acessível apenas para leitura - normalmente ainda através de traduções francesas, como a de Vigny, - relegando o texto de Ducis ao ostracismo. Nesse sentido, é uma pena que não tenhamos documentação que comprove se o texto de 0 Novo Othelo foi alterado em 1871 para ser encenado para Ernesto Rossi por Vasques, imitando-o. De qualquer forma, com a vinda dos estrangeiros Hedelmonda é definitivamente substituída por Desdêmona, que até então só

\footnotetext{
${ }^{286}$ GIRON, Luís Antônio. "O etnógrafo enfarinhado: Gonçalves Dias na guerra contra o entrudo". In
} MÉTIS: História e Cultura, v. 1, no. 1, jan/jun. 2002. Caxias do Sul, EDUCS, 2002, pp. 192-193 
aparecera aos cariocas na ópera de Rossini e em escritos de alguns autores familiarizados com o texto de Shakespeare.

Com novos parâmetros de interpretação, muito distintos entre si especialmente os repentes selvagens de Rossi, a concentração de Salvini e, posteriormente, a "humanização" da personagem proposta por Emanuel - os atores italianos deixaram marcas profundas na compreensão do estudo e da execução de um papel pela platéia e pela crítica carioca, gerando polêmicas como a de 1879, entre as "Cartas de um Caipira", do Jornal do Comércio, e seus opositores.

Com isso, podemos perceber a elevação do nível da crítica, que antes comentava basicamente erros e acertos das encenações, sem compará-las, e focando quase que exclusivamente no desempenho do primeiro ator da companhia, sem, contudo, questionar suas opções artísticas, mas sim, por exemplo, a qualidade de sua dicção. Agora podemos testemunhar a discussão de idéias e preceitos artísticos anteriores ao produto final - a representação em si. Isto vem a demonstrar uma maturidade crítica e deveria gerar, como frutos, um enriquecimento da cena e da apreciação desta.

O motivo da melhoria da crítica de forma geral, claro está, não é Otelo; mas Otelo testemunha, de forma exemplar, tal melhoria.

Infelizmente, aqui podemos nos questionar sobre, de um lado, a profusão de Otelos estrangeiros, que tanto agradaram em cena, e de outro lado, o silêncio absoluto de companhias brasileiras em relação à obra: não há uma única encenação de um Otelo brasileiro no período, a não ser que nos conformemos com as citações interpretadas por Vasques, em $O$ Caboclo. Traduções portuguesas já existiam, como demonstram as representações das companhias de Álvaro Felipe Ferreira e de Eduardo Brazão. Então, por que não há um Otelo brasileiro? Por que os ditames do mercado teatral carioca, centrados na burleta e nas obras cômicas e musicais, não abriram espaço para um único espetáculo de uma obra de Shakespeare no período? Por que esse silêncio perduraria até a década de 1930, e teria que esperar até 1948 para dar, 
finalmente, como resultado, um grande nome do teatro brasileiro ligado a um papel shakespeariano - Sérgio Cardoso e Hamlet?

E mesmo assim, no século $\mathrm{XX}$, teríamos um grande artista cômico autodenominado Grande Otelo... São às vezes tortuosos os caminhos das apropriações no Brasil.

Como demonstramos, apropriações dramatúrgicas de Otelo não faltaram ao longo do século XIX. Estas podem ser divididas em duas linhas principais: a primeira, calcada no Othelo de Ducis e em sua encenação por João Caetano, que enveredou especialmente pela vertente cômica, exemplificada em Os Ciúmes de um Pedestre, de Martins Pena, e em O Novo Othelo, de Joaquim Manuel de Macedo; e a outra, inspirada na obra de Shakespeare, que nos legou obras principalmente sérias, do drama romântico Leonor de Mendonça, de Gonçalves Dias, à experiência naturalista de $O$ Caboclo, de Aluísio Azevedo e Emílio Rouède. Demonstramos também, brevemente, a recorrência de Otelo e de Desdêmona em citações esparsas em outros textos, especialmente como protótipos de certas características.

A presença e a permanência de Otelo no Brasil parece, pois, bem estruturada. Podemos perceber os caminhos percorridos e seus frutos, e refletirmos sobre 0 alcance das apropriações empreendidas. Não cremos, certamente, ter esgotado o assunto, até porque outras peças de Shakespeare - notadamente Hamlet, Romeu e Julieta, Rei Lear e O Mercador de Veneza - também mereceriam um estudo detido, nos mesmos padrões. Mas os documentos e obras permitem-nos afirmar a primazia de Otelo sobre as outras obras shakespearianas em relação a seu papel na criação dramatúrgica nacional, algo que nem Hamlet, com todas as citações de diferentes autores e traduções de trechos no período, foi capaz de alcançar. Isto deriva do caráter intrínseco da peça, de seu entrecho mais doméstico do que as outras grandes tragédias shakespearianas, e de como seu enredo e personagens podem servir a diferentes propósitos, cômicos e sérios. Nesse sentido, não há peça como Otelo. E os autores nacionais não se furtaram a valer-se da obra para seus próprios fins, em maior ou menor grau, e em diferentes gêneros, em uma gama 
de textos que incluem ao menos duas obras-primas da literatura nacional: Leonor de Mendonça, no teatro, e Dom Casmurro, no romance.

Com o trabalho ora apresentado, cremos ter podido contribuir para o estudo e a expansão do conhecimento a propósito das relações entre Shakespeare e o Brasil, e também do panorama teatral brasileiro no século XIX. Nos anexos que se seguem, tentamos selecionar materiais que ajudem a iluminar ainda um pouco mais as questões tratadas. No primeiro deles, apresentamos uma tabela que demonstra detalhadamente as apropriações que Macedo fez de falas do Othelo de Ducis na composição de sua comédia O Novo Othelo. No segundo anexo, trazemos imagens de anúncios, fotografias e ilustrações relativas aos diferentes Otelos do século XIX. Finalmente, o longo Anexo 3 pretende dar conta de um grande espectro de críticas publicadas no Brasil relativas a Otelo. Mesmo a citação exaustiva das mesmas não daria conta de sua riqueza; julgamos melhor, pois, apresentá-las da forma mais completa possível como um adendo. Sozinhas, as críticas já seriam assunto para um estudo exaustivo e interessante, especialmente sobre a passagem das companhias estrangeiras no Rio de Janeiro. Não sendo esta a nossa proposta inicial, deixamo-las como pano de fundo para reflexão e para uma compreensão mais ampla do fenômeno Otelo nos palcos cariocas do período.

Fiquemos, pois, com as palavras de Otelo, ao fim de sua trajetória:

"OTELO - (...)

Meu caminho acabou, este é o meu fim;

É o ponto final da minha vela.

Recuam pálidos? É medo inútil:

Qualquer palha no peito, e logo Otelo

Bate em retirada. Mas, pra onde?

Agora, como está? Moça infeliz,

Branca de linho; no acertar das contas,

Seu rosto há de banir do céu minh'alma,

Pro diabo agarrar. Fria, menina,

Como a sua pureza; escravo vil!

Açoitem-me, demônios, 
Me privem de poder ter tal visão!

Batam-me ao vento! Queimem-me no enxofre,

Lavando-me num mar de fogo líquido!

Desdêmona, Desdêmona! 'Stá morta!'”287

287 SHAKESPEARE, William. Otelo, o Mouro de Veneza, tradução de Bárbara Heliodora. Rio de Janeiro, Lacerda, 1999, pp. 189-190. 


\section{REFERÊNCIAS BIBLIOGRÁFICAS}

ACKROYD, Peter. Shakespeare - The Biography. London, Chatto \& Windus, 2005.

AGUIAR, Flávio (org.). O Teatro de Inspiração Romântica. São Paulo, Senac, 1998.

(org.). A Aventura Realista e o Teatro Musicado. São Paulo, Senac, 1998.

ALENCAR, José de. Crônicas Escolhidas. São Paulo, Editora Folha, 1995.

ALMEIDA, Bárbara Heliodora. "Shakespeare in Brazil", in Shakespeare Survey no. 20. Cambridge, CUP, 1967, pp. 121-124.

ALVES, Ívia Iracema D. Visões de Espelhos - o Percurso da Crítica de Eugênio Gomes. São Paulo, tese de Doutoramento apresentada à FFLCH / USP, 1995, 2v.

AMORA, A. Soares. A Literatura Brasileira, volume II - o Romantismo (18331838 / 1878-1881). $3^{\text {a }}$ ed. São Paulo, Cultrix, 1969.

ANDRADE, Ayres de. Francisco Manuel da Silva e seu Tempo. Rio de Janeiro, Tempo Brasileiro, 1967, 2 v.

ARÊAS, Vilma Sant'Anna. Na Tapera de Santa Cruz - uma Leitura de Martins Pena. São Paulo, Martins Fontes, 1987.

AZEVEDO, Álvares de. Macário. Porto Alegre, L\&PM, 2001. 
. Teatro de Álvares de Azevedo: Macário / Noite na Taverna. São Paulo, Martins Fontes, 2002.

AZEVEDO, Elizabeth R. Um Palco sob as Arcadas - o Teatro dos Estudantes de Direito do Largo de São Francisco, em São Paulo, no Século XIX. São Paulo, Annablume; Fapesp, 2000.

BALDICK, Robert. La Vie de Frédérick Lemaître - le Lion du Boulevard. Paris, Éditions Denoël, 1961.

BARROS, Diana Luz P. de e FIORIN, José Luiz (orgs.). Dialogismo, Polifonia, Intertextualidade. São Paulo, Edusp, 1994.

BARROS, Roque Spencer Maciel de. A Significação Educativa no Romantismo Brasileiro: Gonçalves de Magalhães. São Paulo, Grijalbo/Edusp, 1973.

BATE, Jonathan (ed.). The Romantics on Shakespeare. London, Penguin, 1992.

BERTHOLD, Margot. História Mundial do Teatro. São Paulo, Perspectiva, 2000.

BLOOM, Harold. Abaixo as Verdades Sagradas: Poesia e Crença desde a Bíblia até Nossos Dias. São Paulo, Companhia das Letras, 1993.

. O Cânone Ocidental. Rio de Janeiro, Editora Objetiva, 1995.

. Shakespeare and the Invention of the Human. New York, Riverhead, 1998.

. Shakespeare: a Invenção do Humano. Rio de Janeiro, Editora Objetiva, 1998.

. Gênio. Rio de Janeiro, Editora Objetiva, 2003. 
Hamlet, Poema llimitado. Rio de Janeiro, Editora Objetiva, 2005.

BORIE, M., ROUGEMONT, M. \& SCHERER, J. (orgs.). Estética Teatral Textos de Platão a Brecht. Lisboa, Fundação Calouste Gulbenkian, 1956.

BOSI, Alfredo et allii (org.). Machado de Assis. São Paulo, Ática, 1981.

BOSI, Alfredo. Machado de Assis - o Enigma do Olhar. São Paulo, Editora Ática, 2003.

BOYDELL, John and Josiah. Boydell's Shakespeare Prints. New York, Dover Publications, 2004.

BRADLEY, A.C. Shakespearean Tragedy. New York, Meridian Books, 1955.

BRAGAGLIA, Leonardo. Shakespeare in Italia. Bologna, Paolo Emilio Persiani Editore, 2005.

BULMAN, James C. (Ed.). Shakespeare, Theory, and Performance. London, Routledge, 1996.

CACCIAGLIA, Mário. Pequena História do Teatro no Brasil: Quatro Séculos de Teatro no Brasil. São Paulo, T. A. Queiroz / EDUSP, 1986.

CALDWELL, Helen. Machado de Assis - the Brazilian Master and his Novels. Berkeley, University of California Press, 1970.

O Otelo Brasileiro de Machado de Assis. Cotia, Ateliê Editorial, 2002.

CÂNDIDO, Antonio. Tese e Antítese. São Paulo, Companhia Editora Nacional, 1964. 
. Formação da Literatura Brasileira. $3^{\text {a }}$ ed. São Paulo, Livraria Martins Editora, 1969.

. O Romantismo no Brasil, $2^{\mathrm{a}}$ ed. São Paulo, Humanitas/FFLCH, 2004.

CÂNDIDO, A, e CASTELLO, J.A. Presença da Literatura Brasileira - das Origens ao Realismo. $3^{\text {a }}$ ed. Rio de Janeiro, Bertrand Brasil, 1988.

CARLSON, Marvin. The Italian Shakespearians. Washington, Folger Books, 1985.

CASTELLO, José Aderaldo (ed.). Textos que Interessam à História do Romantismo. São Paulo, Conselho Estadual de Cultura, Comissão de Literatura, 1960.

CHAGAS, Wilson. A Fortuna Crítica de Machado de Assis. Porto Alegre, Editora Movimento, 1994.

CHEVALLEY, Sylvie. "Ducis, Shakespeare et les comédiens français". In Revue d'Histoire du Théâtre. 16ème année. Paris, no. 4, Octobre/Décembre 1964, pp. 327-351 et no. 1, Janvier/Mars 1965, pp. 5-37.

COELHO, Lauro Machado. A Ópera Romântica Italiana. São Paulo, Perspectiva, 2002.

. A Ópera Italiana após 1870. São Paulo, Perspectiva, 2002.

A Ópera Clássica Italiana. São Paulo, Perspectiva, 2003.

COMPAGNON, Antoine. La Seconde Main - Le Travail de la Citation. Paris, Le Seuil, 1979.

CORTI, Cláudia. Shakespeare Illustrato. Roma, Bulzoni Editore, 1996. 
COUTINHO, Afrânio e SOUSA, J. Galante de (dir.). Enciclopédia da Literatura Brasileira. $2^{\mathrm{a}}$ ed. revista, ampliada, atualizada e ilustrada sob a coordenação de Graça Coutinho e Rita Moutinho. São Paulo, Global Editora; Rio de Janeiro, Biblioteca Nacional /DNL: Academia Brasileira de Letras, 2001.

DAHLHAUS, Carl. La Musica Dell'Ottocento. Firenze, La Nuova Italia Editrice, 1990.

D'ARNAUD, Baculard. Fayel. Paris, Chez Delalain, 1778.

Fayel, $2^{\mathrm{a}}$ ed., trad. João Batista Gomes. Porto, Oficina de Antonio Álvares Ribeiro, 1803.

DÁVIDHÁZI, Péter. The Romantic Cult of Shakespeare. London, Macmillan Press, 1998.

DEAN, Winton. "Shakespeare in the Opera House", in Shakespeare Survey vol. 18. Cambridge, CUP, 1965, pp. 75-93.

. "Verdi's 'Otello': a Shakespearian Masterpiece", in Shakespeare Survey vol. 21. Cambridge, CUP, 1968, pp. 87-96

DELABASTITA, D. \& D'HULST, L. (eds.). European Shakespeares. Amsterdam, John Benjamins, 1993.

DELISLE, Jean \& Woodsworth, Judith (eds.). Translators Through History. Amsterdam, John Benjamins, 1995.

DESCOTES, Maurice. Le Drame Romantique et ses Grands Créateurs (18271839). Paris, PUF, s/d.

DONOHUE, Joseph. Theatre in the Age of Kean. Oxford, Basil Blackwell, 1975. 
Dossier "Alexandre Dumas 200 ans après ", in Magazine Littéraire n. 412. Paris, Septembre 2002.

DUCIS, Jean-François. "Othello, ou Le More de Venise", in Théâtre Contemporain Illustré, tomo 9. Paris, Michel Lévy Frères Éditeurs, s/d.

. Othello, édition critique par Christopher Smith. Exeter, University of Exeter Press, 1991.

DUMAS, Alexandre. La Vie d'Alexandre Dumas Racontée par Alexandre Dumas - Textes Récueillis par Alain Guérain. Paris, Julliard, 1953. . Kean. Paris, Gallimard, 1954. . Théâtre Complet I. Paris, Minard, 1974.

EYRE, Richard \& WRIGHT, Nicholas. Changing Stages. London, Bloomsbury, 2000.

FARIA, João Roberto. O Teatro Realista no Brasil: 1855-1865. São Paulo, Perspectiva, 1993.

- Idéias Teatrais: o Século XIX no Brasil. São Paulo, Perspectiva/FAPESP, 2001. . "A Formação do Teatro Brasileiro", in: O Teatro na Estante. São Paulo, Ateliê Editorial, 1998, pp. 15-32.

. "A Dramaturgia do Classicismo", in GUINSBURG, J. (org.) $O$ Classicismo. São Paulo, Perspectiva, 1999, pp. 139-174. (org.). Teatro de Aluísio Azevedo e Emílio Rouède. São Paulo, Martins Fontes, 2002. 
FRANÇA JÚNIOR, Joaquim José de. Teatro de França Júnior I. Rio de Janeiro, SNT, Fundação Nacional da Arte, 1980.

FREIXIEIRO, Fábio. Alencar, os Bastidores e a Posteridade. Rio de Janeiro, Museu Histórico Nacional, 1977.

FRYE, Northorp. Sobre Shakespeare. São Paulo, Edusp, 1992.

GAUTIER, Théophile. Histoire de l'Art Dramatique en France depuis Vingt-cinc Ans. Paris, Hetzel, 1858-1859, 2 v.

GIRON, Luís Antônio. "O etnógrafo enfarinhado: Gonçalves Dias na guerra contra o entrudo". In MÉTIS: História e Cultura, v. 1, no. 1, jan/jun. 2002. Caxias do Sul, EDUCS, 2002, pp. 185-200.

Minoridade Crítica: A Ópera e o Teatro nos Folhetins da Corte. São Paulo, Edusp; Rio de Janeiro, Ediouro, 2004.

GILMAN, Margaret. Othello in French. Paris, s/e, 1925.

GLEDSON, John. Machado de Assis - Impostura e Realismo. São Paulo, Companhia das Letras, 1991.

GOMES, André Luís. As Marcas de Nascença - A Contribuição de Gonçalves de Magalhães para o Teatro Brasileiro. Dissertação de Mestrado. São Paulo, FFLCH/USP, 1998.

GOMES, Celuta M. William Shakespeare no Brasil. Rio de Janeiro, MEC, 1961.

GOMES, Eugênio. Aspectos do Romance Brasileiro. Salvador, Livraria Progresso Editora / UFBA, 1958. 
. Shakespeare no Brasil. Rio de Janeiro, MEC/Serviço de Documentação, 1961.

- A Neve e o Girassol. São Paulo, Conselho Estadual de Cultura / Comissão de Literatura, 1967.

O Enigma de Capitu. Rio de Janeiro, Livraria José Olympio Editora, 1967.

. Machado de Assis - Influências Inglesas. Rio de Janeiro, Pallas;

Brasília, INL, 1976.

. Espelho Contra Espelho. São Paulo, Instituto Progresso Editorial, s/d.

GONÇALVES DIAS, A. Teatro Completo. Rio de Janeiro, SNT, 1979.

Poesia. Org. por Manuel Bandeira. $6^{a}$ ed. Rio de Janeiro, Agir, 1974.

GONÇALVES DE MAGALHÃES. Domingos José Carlos. Obras. Rio de Janeiro, Livraria de B.L. Garnier, 1864-1865, v. 3.

GREENBLATT, Stephen. Will in the World - How Shakespeare Became Shakespeare. London, PIMLICO, 2005.

GRELON, F. "Shakespeare et la Jalousie", In Études Anglaises, t. XVII, n. 4. Paris, Didier, 1964, pp. 390-401.

GROSS, John (Ed.). After Shakespeare. Oxford, Oxford University Press, 2002.

GUINSBURG, J (org.). O Romantismo. São Paulo, Perspectiva, 1978. 
HARTNOLL, P. The Theatre - a Concise History. New York, Thames and Hudson, 1991.

HELIODORA, Bárbara. Falando de Shakespeare. São Paulo, Perspectiva; Rio de Janeiro, FUNARTE / Cultura Inglesa, 1997.

HEPOKOSKI, James A. Giuseppe Verdi, Otello. Cambridge, CUP, 1987.

HESSEL, Lothar \& RAEDERS, Georges. O Teatro no Brasil sob D. Pedro II. Porto Alegre, Ed. da UFRGS/IEL, 1979 a 1986, 2v.

HUGO, Victor. Do Grotesco e do Sublime - Tradução do prefácio de Cromwell. São Paulo, Ed. Perspectiva, s/d.

. William Shakespeare. Londrina, Campanário, 2000.

HUGUES, Glenn. The Story of the Theatre, revised edition. London, Ernest Benn Limited, 1928.

HUPPES, Ivete. Gonçalves de Magalhães e o Teatro do Primeiro Romantismo. Porto Alegre, Movimento; Lajeado, Fates, 1993.

Melodrama - o Gênero e sua Permanência. São Paulo, Ateliê, 2000.

JACOBBI, Ruggero. Goethe, Schiller, Gonçalves Dias. Porto Alegre, Editora da UFRGS, 1958.

JACQUOT, Jean. "Le Macbeth de Ducis". In Études Anglaises, t. XVII, n. 4. Paris, Didier, 1964, pp. 605-627.

JAMESON, Anna. Shakespeare's Heroines - Characteristics of Women: Moral, Poetical and Historical. New York, Gramercy Books; Random House, 2003. 
JENNY, Laurent. "La Stratégie de la Forme". In Poétique, n. 27, Paris, 1976.

JOBIM, José Luís (org.). A Biblioteca de Machado de Assis. Rio de Janeiro, Academia Brasileira de Letras / Topbook, 2001.

JOHNSON, Samuel. Prefácio a Shakespeare, trad. Enid A. Dobránszky. São Paulo, lluminuras, 1996.

JULLEVILLE, Petit de. Le Théâtre en France. Nouvelle Édition. Paris, Librairie Armand Colin, 1927.

KENNEDY, Dennis. Looking at Shakespeare - a Visual History of Twentiethcentury Performance. Cambridge, CUP, 1993.

(Ed.). Foreign Shakespeare - Contemporary Performance. Cambridge, CUP, 1993.

KERMAN, Joseph. Opera as Drama. New York, Random House, 1956. A Ópera como Drama. Rio de Janeiro, Jorge Zahar Editor, 1990.

KOBBÉ, Gustave. O Livro Completo da Ópera. Trad. Clóvis Marques. Rio de Janeiro, Jorge Zahar Editor, 1997.

KOTT, Ian. "Les deux paradoxes d'Othello". In Études Anglaises, t. XVII, n. 4. Paris, Didier, 1964, pp. 402-420.

LANCELLOTTI, Arturo. I Sovrani della Scena. Roma, Editrice Faro, s/d.

LENZI, Massimo. L'Istrione Iperboreo - Le Figurazioni Sceniche di Adelaide Ristori ed Ernesto Rossi nel Prisma della Critica Russa Contemporanea (18601896). Pisa, Edizioni ETS, 1993. 
LEWES, George Henry. Gli Attori e l'Arte della Recitazione. Milano, Costa \& Nolan, 1999.

LEWINTER, Oswald (ed.). Shakespeare in Europe. Cleveland, The World Publishing Company, 1963.

LIOURE, Michel. Le Drame de Diderot à lonesco. Paris, Librairie Armand Colin, 1973.

LONGYEAR, Rey M. Nineteenth-century Romanticism in Music. $3^{\text {rd }}$ ed. London, Prentice Hall, 1988.

LUQUE, Antonio Dominguez. "Um acercamento a la única obra shakespeariana de Rossini: Otello, o sia il Moro di Venezia", in Filomusica, Revista de Música Culta, revista mensual de publicación en Internet, número 68, septiembre 2005. (http://www.filomusica.com/filo68/otello.html, último acesso em 06/05/2007)

MACEDO, Joaquim Manoel de. Anno Biográphico Brazileiro. Rio de Janeiro, Typhografia e Lithografia do Imperial Instituto Artístico, 1876, 3v.

- Teatro Completo. Rio de Janeiro, Ministério da Educação e Cultura, Funarte, SNT, 1979, 2v.

. "O Novo Othelo", in Teatro da Juventude - ano 4 - no. 20. São Paulo, Secretaria da Cultura, outubro/1998, pp. 95-106. . A Moreninha. São Paulo, Ática, 1988.

MACHADO, Alcântara. Gonçalves de Magalhães ou o Romântico Arrependido. São Paulo, Livraria Acadêmica, 1936.

MACHADO DE ASSIS, J.M. "Instincto de Nacionalidade", in Crítica Litterária. Rio de Janeiro, W. M. Jackson Inc., 1910. 
. Crítica Teatral. Rio de Janeiro, W. M. Jackson, 1961, v. 30.

Teatro. Rio de Janeiro, W. M. Jackson, 1962, v. 19.

. Teatro Completo. Rio de Janeiro, MEC / SNT, 1982.

. Dom Casmurro. São Paulo, Editora Ática, 1996.

MAGALDI, Sábato. Panorama do Teatro Brasileiro. $3^{\mathrm{a}}$ ed. revista e ampliada. São Paulo, Global, 1997.

MAGALHÃES, D.J.G. de. Obras de D.J.G. de Magalhães - Tomo III Tragédias. Rio de Janeiro, Livraria de B.L. Garnier, 1865.

MAGALHÃES JÚNIOR, R. José de Alencar e Sua Época, $2^{\text {a }}$ edição, corrigida e aumentada. Rio de Janeiro, Civilização Brasileira, 1977.

MARIENSTRAS, R. "La dégradation de vertus heröiques dans Othello et dans Coriolanus". In Études Anglaises, t. XVII, n. 4. Paris, Didier, 1964, pp. 372-399.

MARTINS, Márcia A. P. "Shakespeare in Brazilian Portuguese: Hamlet as a Case in Point", in Ilha do Desterro - a Journal of English Language, Literatures in English and Cultural Studies, n. 36, jan/jun 1999. Florianópolis, Editora da UFSC, 1999, pp. 283-308.

MARTINS PENA, Luis Carlos. Comédias. Rio de Janeiro, Ediouro, s/d. . Teatro de Martins Pena, ed. Crítica por Darcy Damasceno. Rio de Janeiro, MEC, Instituto Nacional do Livro, 1956.

- Folhetins - A Semana Lírica. Rio de Janeiro, Ministério da Educação e Cultura / Instituto Nacional do Livro, 1965. 
- Obras Completas. Rio de Janeiro, MEC, Funarte, Serviço Nacional de Teatro, 1979, 2v.

. As Melhores Comédias de Martins Pena. Porto Alegre, Editora Mercado Aberto, 1987.

MAUROIS, André. Les Trois Dumas. Paris, Hachette, 1957.

MENDES, Míriam Garcia. A Personagem Negra no Teatro Brasileiro (entre 1838 e 1888). Dissertação de Mestrado. São Paulo, ECA/USP, s/d.

MENEZES, Raimundo de. Aluísio Azevedo: uma Vida de Romance. São Paulo, Livraria Martins Editora, 1958.

. Cartas e Documentos de José de Alencar. São Paulo, Conselho Estadual de Cultura, 1967.

MERCHANT, Christina. "Delacroix's Tragedy of Desdemona", in Shakespeare Survey, vol. 21. Cambridge, CUP, 1968, pp. 79-86.

MONACO, Marion. Shakespeare on the French Stage in the Eighteenth Century. Paris, Didier, s/d.

OBERDORFER, Aldo (org.) Verdi, Autobiographie à travers la Correspondance. Paris, Éditions Jean-Claude Lattès, 1984.

ORECCHIA, Donatella. II Sapore della Menzogna. Genova, Costa \& Nolan, 1996.

OSBORNE, Charles. The Complete Opera of Verdi. London, Victor Gollancz, 1969.

. Verdi - Vida e Ópera. Rio de Janeiro, Jorge Zahar Editor, 1989. 
PARSONS, Keith \& MASON, Pamela (Eds.). Shakespeare in Performance. London, Salamander, 1995.

PASCAL, Roger. Shakespeare in Germany 1740-1815. Cambridge, CUP, 1937.

PAULIN, Roger. The Critical Reception of Shakespeare in Germany 1682-1914 - Native Literature and Foreign Genius. Hildesheim, Georg Olms Verlag, 2003.

PEREIRA, Lúcia Miguel. Machado de Assis: Estudo Crítico e Biográfico. $6^{\text {a }}$ ed. revista. Belo Horizonte, Itatiaia; São Paulo, Edusp, 1988.

PIÉGAY-GROS, Nathalie. Introduction à l'Intertextualité. Paris, Dunod, 1996.

PORTO ALEGRE e GONÇALVES DE MAGALHÃES. Cartas a Monte Alverne. Apresentação de Roberto Lopes. São Paulo, Conselho Estadual de Cultura, 1964.

PRADO, Décio de Almeida. João Caetano. São Paulo, Perspectiva / EDUSP, 1972.

. João Caetano e a Arte do Ator. São Paulo, Ática, 1984.

. Teatro de Anchieta a Alencar. São Paulo, Perspectiva, 1993.

. História Concisa do Teatro Brasileiro. São Paulo, EDUSP, 1999.

PRESSLY, William L. A Catalogue of Paintings in the Folger Shakespeare Library: as Imagination Bodies Forth. New Haven, Yale University Press, 1993.

PUJANTE, A. Luis \& HOENSELAARS,Ton (Eds.). Four Hundred Years of Shakespeare in Europe. Newark, University of Delaware Press, 2003.

RIBEIRO, José Antonio Pereira. O Universo Romântico de Joaquim Manuel de Macedo. São Paulo, Roswita Kempf/Editores, 1987. 
ROMERO, Sílvio. História da Literatura Brasileira, 5a. ed. Rio de Janeiro, José Olympio, 1953.

ROSEN, Charles. A Geração Romântica. Ed. rev. e ampl. São Paulo, EDUSP, 2000.

ROSENBERG, Marvin. The Masks of Othello. Berkeley; Los Angeles, University of California Press, 1971.

ROSSI, Ernesto. Quarant'Anni di Vita Artistica. Volume Terzo. Firenze, Tip. Ed. Di L. Nicolai, 1889.

SALVINI, Celso. Tommaso Salvini nella Storia del Teatro Italiano e nella Vita del suo Tempo. Rocca San Casciano, Cappelli, 1955.

SALVINI, Tommaso. "Leaves from the Autobiography of Salvini", in The Century Illustrated Monthly Magazine, Volume XLVI, \#3, July, 1893, pp. 363-368, e Volume XLVI, \# 5/6, September/October, 1893, pp. 779-789; 927-938.

SANTOS, João Caetano dos. Lições Dramáticas. Rio de Janeiro, Serviço de Documentação - MEC, 1955.

SANTOS, Marlene Soares dos. "Shakespeare's OTHELLO: its Presence in the History of the Brazilian Theatre", in ANAIS do XXIII SENAPULLI. Belo Horizonte, UFMG / Imprensa Universitária, 1991.

SAYERS, Raymond. O Negro na Literatura Brasileira. Rio de Janeiro, Ed. O Cruzeiro, s/d.

SCHMIDGALL, Gary. Shakespeare and Opera. Oxford, Oxford University Press, 1990. 
SCHWARZ, Roberto. Um Mestre na Periferia do Capitalismo: Machado de Assis. $4^{\text {a }}$ ed. São Paulo, Duas Cidades; Editora 34, 2000. . Duas Meninas. São Paulo, Companhia das Letras, 1997.

SERRA, Tânia Rebelo Costa. Joaquim Manuel de Macedo ou Os Dois Macedos: a Luneta Mágica do I/ Reinado. Rio de Janeiro Fundação Biblioteca Nacional, Departamento Nacional do Livro, 1994.

SHAKESPEARE, William. Othello with the English and Italian Words as Performed by Signor Salvini. New York, Koppel, 1889. . The Complete Works. London, Atlantis, 1980. . Othello, traduit par François-Victor Hugo. Paris, Librio, 1996. . Romeu e Julieta. Trad. de Bárbara Heliodora, edição bilíngüe. Rio de Janeiro, Nova Fronteira, 1997, $5^{\text {a }}$ reimpressão. . Otelo, o Mouro de Veneza. Trad. de Bárbara Heliodora. Rio de Janeiro, Nova Aguilar, 1999.

SILVA, José Carlos Ruiz. "Shakespeare-Verdi: 'Otello'. Estúdio comparado del 'Othello' de Shakespeare y de su transformación en libretto de opera”, in Anales y Bolétin de la R.A. de Bellas Artes de San Fernando. Madrid, 1976, pp. 25-48.

SILVA, Lafaiete. História do Teatro Brasileiro. Rio de Janeiro, Ministério da Educação, 1938.

SMET, Robert de. "Othello in Paris and Brussels", in Shakespeare Survey, vol 3. Cambridge, CUP, 1950, pp. 98-106. 
SPEAIGHT, Robert. Shakespeare on the Stage: an Illustrated History of Shakespearian Performance. Boston, Little, Brown \& Company, 1973.

SOUSA, J. Galante de. O Teatro no Brasil. Rio de Janeiro, MEC/INL, 1960, 2v.

STANISLAVSKI, Konstantin S. Minha Vida na Arte. Rio de Janeiro, Editora Civilização Brasileira, 1989.

STENDHAL. Vida de Rossini, seguido de Notas de um Diletante. São Paulo, Companhia das Letras, 1995. . Racine e Shakespeare. Palermo, Sellerio Editore, 1980.

TAMES, Richard. Giuseppe Verdi. London, Franklin Watts, 1991.

TAYLOR, John Russel. Dictionary of the Theatre. $3^{\mathrm{a}}$ ed. London, Penguin, 1993.

The Theatre Museum London, catálogo. London, Scala Books, 1987.

TILL, Nicolas. Rossini. London, Omnibus Press, 1987.

VERDI, Giuseppe. Lettere 1835-1900. Milano, Arnoldo Mondadori Editore, 2000.

. Libretti. Milano, Arnoldo Mondadori Editore, 2000.

. Otello. Programa da Temporada 2003-2004. Paris, Opéra National de Paris, 2003.

. Otello. Programa da Temporada 2004-2005. Milano, Edizioni del Teatro alla Scalla, 2004. 
VILLEHERVÉ, Bertran de la. François Thomas de Baculard D'Arnaud - son Théâtre et ses Théories Dramatiques. Paris, Librairie Edouard Champion, 1920.

VOLOSHINOV, V. N. Marxism and the Philosophy of Language. New York, Seminar Press, 1973.

VOLTAIRE. CEuvres Choisies. Paris, Chez P. Dupont, 1826. . Lettres Anglaises. Paris, Jean-Jacques Pauvert, 1964.

WELLS, Stanley (Ed.). The Cambridge Companion to Shakespeare Studies. Cambridge, Cambridge University Press, 1986.

WHITE, R.S., EDELMAN, Charles \& WORTHAM, Christopher (Eds.). Shakespeare - Readers, Audiences, Players. Nedlands, University of Western Australia Press, 1998.

WOOD, Michael. In Search of Shakespeare. London, BBC, 2003.

ZIMMERMANN, Daniel. Alexandre Dumas le Grand. Paris, Julliard, 1993. 


\section{PERIÓDICOS CONSULTADOS}

A Comédia Social (1871)

A Mocidade

Anno Biographico Brazileiro

A Reforma (1871)

A Semana

A Vida Fluminense (1871)

Brazil-Theatro

Correio Comercial (1879)

Correio da Manhã - RJ (1924)

Correio da Noite (1879)

Correio da Tarde - RJ (1894)

Diário de Notícias - RJ (1871, 1894)

Diário do Rio de Janeiro

Dionysos (1978)

Gazeta de Notícias

Imprensa da Tarde, depois renomeado A Imprensa (1879) 
Jornal da Tarde (1871)

Jornal do Brasil (1891)

Jornal do Comércio

Novidades $(1887,1891)$

O Arauto (1879)

O Echo Social (1879)

O Estado de São Paulo

O Guarany (1871)

O Observatório

República (1871)

Revista Dramática (SP)

Revista da Sociedade Fênix Literária (1879)

Revista Fluminense

Revista llustrada $(1879,1887)$

Revista Teatral (1894)

Semana llustrada - RJ (1871)

SITES CONSULTADOS - último acesso em 06/07/2007. 
http://www.academia.org.br

http://www.academie-francaise.fr

http://amy.music.udel.edu

http://www.bartleby.com/215

http://www.bn.br

http://www.britannica.com

http://www.casadellamusica.it

http://www.content.answers.com

http://www.culs.canterbury.ac.nz

http://www.drammaturgia.it

http://www.emilydickinson.it

http://www.etc.usf.edu

http://www.filomusica.com

http://www.folger.edu

http://www.geocities.com

http://homepage.univie.ac.at

http://www.internetculturale.it

http://italophiles.com

http://lectura.fr

http://www.machadodeassis.org.br

http://www.museoattore.it

http://www.nyu.edu

http://www.operaclick.com

http://opera.stanford.edu/iu/libretti/rotello1.html

http://www.operone.de

http://www.peopleplay.org.uk

http://www.radio.rai.it

http://www.ricordi.it

http://www.rossinigesselschaft.de

http://search.eb.com/shakespeare

http://shakespeare.palomar.edu

http:///www.tap.org.br

http://www.unibas.ch/anglist 
http://upload.wikipedia.org

http://www.wikipedia.org 